\title{
Late Cenozoic Benthic Foraminifers of the HLA Borehole Series, Beaufort Sea Shelf, Alaska
}

U.S. GEOLOGICAL SURVEY BULLETIN 2055

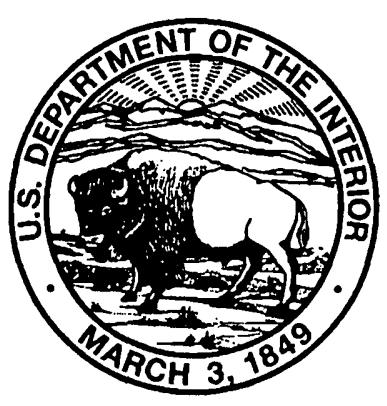




\section{AVAILABILITY OF BOOKS AND MAPS OF THE U.S. GEOLOGICAL SURVEY}

Instructions on ordering publications of the U.S. Geological Survey, along with prices of the last offerings, are given in the currentyear issues of the monthly catalog "New Publications of the U.S. Geological Survey." Prices of available U.S. Geological Survey publications released prior to the current year are listed in the most recent annual "Price and Availability List." Publications that are listed in various U.S. Geological Survey catalogs (see back inside cover) but not listed in the most recent annual "Price and Availability List" are no longer available.

Reports released through the NTIS may be obtained by writing to the National Technical Information Service, U.S. Department of Commerce, Springfield, VA 22161; please include NTIS report number with inquiry.

Order U.S. Geological Survey publications by mail or over the counter from the offices given below.

\section{BY MAIL}

\section{Books}

Professional Papers, Bulletins, Water-Supply Papers, Techniques of Water-Resources Investigations, Circulars, publications of general interest (such as leaflets, pamphlets, booklets), single copies of Earthquakes \& Volcanoes, Preliminary Determination of Epicenters, and some miscellaneous reports, including some of the foregoing series that have gone out of print at the Superintendent of Documents, are obtainable by mail from

\section{U.S. Geological Survey, Map Distribution Box 25286, MS 306, Federal Center Denver, CO 80225}

Subscriptions to periodicals (Earthquakes \& Volcanoes and Preliminary Determination of Epicenters) can be obtained ONLY from the

\section{: Superintendent of Documents Government Printing Office $\because \quad$ Washington, DC 20402}

(Check or money order must be payable to Superintendent of Documents.)

\section{Maps}

For maps, address mail orders to

\section{U.S. Geological Survey, Map Distribution Box 25286, Bldg. 810, Federal Center Denver, CO 80225}

Residents of Alaska may order maps from

\author{
U.S. Geological Survey, Earth Science Information Center \\ 101 Twelfth Ave., Box 12 \\ Fairbanks, AK 99701
}

\section{OVER THE COUNTER}

\section{Books and Maps}

Books and maps of the U.S. Geological Survey are available over the counter at the following U.S. Geological Survey offices, all of which are authorized agents of the Superintendent of Documents.

- ANCHORAGE, Alaska-4230 University Dr., Rm. 101

- LAKEWOOD, Colorado-Federal Center, Bldg. 810

- MENLO PARK, California-Bldg. 3, Rm. 3128, 345 Middlefield Rd.

- RESTON, Virginia-National Center, Rm. 1C402, 12201 Sunrise Valley Dr.

- SALT LAKE CITY, Utah-Federal Bldg., Rm. 8105, 125 South State St.

- SPOKANE, Washington-U.S. Post Office Bldg., Rm. 135, W. 904 Riverside Ave.

- WASHINGTON, D.C.-Main Interior Bldg., Rm. 2650, 18th and C Sts., NW.

\section{Maps Only}

Maps may be purchased over the counter at the U.S. Geological Survey offices:

- FAIRBANKS, Alaska-New Federal Building, 101 Twelfth Ave.

- ROLLA, Missouri-1400 Independence Rd.

- STENNIS SPACE CENTER, Mississippi-Bldg. 3101 


\section{Late Cenozoic Benthic Foraminifers of the HLA Borehole Series, Beaufort Sea Shelf, Alaska}

By Kristin McDougall

U.S. GEOLOGICAL SURVEY BULLETIN 2055

Benthic foraminiferal assemblages in marine strata of 18 boreholes in the Beaufort Sea shelf are correlated with late Cenozoic marine transgressions. Paleoenvironmental interpretations of the transgression are based on these benthic foraminifers 


\title{
U.S. DEPARTMENT OF THE INTERIOR BRUCE BABBITT, Secretary
}

\author{
U.S. GEOLOGICAL SURVEY \\ Gordon P. Eaton, Director
}

For sale by

U.S. Geological Survey, Map Distribution

Box 25286, MS 306, Federal Center

Denver, CO 80225

\author{
Any use of trade, product, or firm names in this publication is for descriptive purposes only and does \\ not imply endorsement by the U.S. Government \\ Text and illustrations edited by Mary Lou Callas \\ Graphics prepared by Eleanor V. Kohnen \\ Book designed by Lisa Baserga \\ Library of Congress Cataloging in Publication Data \\ Late Cenozoic benthic foraminifers of the HLA borehole series, Beaufort Sea Shelf, Alaska / by Kristin McDougall. \\ p. cm.-(U.S. Geological Survey bulletin ; 2055) \\ Includes bibliographical references and index. \\ Supt. of Docs. no.: I 19.3:2055 \\ 1. Foraminifera, Fossil-Alaska. 2. Foraminifera, Fossil-Beaufort Sea Region. 3. Paleontology-Alaska. \\ 4. Paleontology-Beaufort Sea Region. 5. Paleontology-Pliocene. I. Title. II. Series.
}

McDougall, Kristin A.

QE75.B9 no. 2055

[QE772]

$557.3 \mathrm{~s}-\mathrm{dc} 20$

[563'.12'09798] 


\section{CONTENTS}

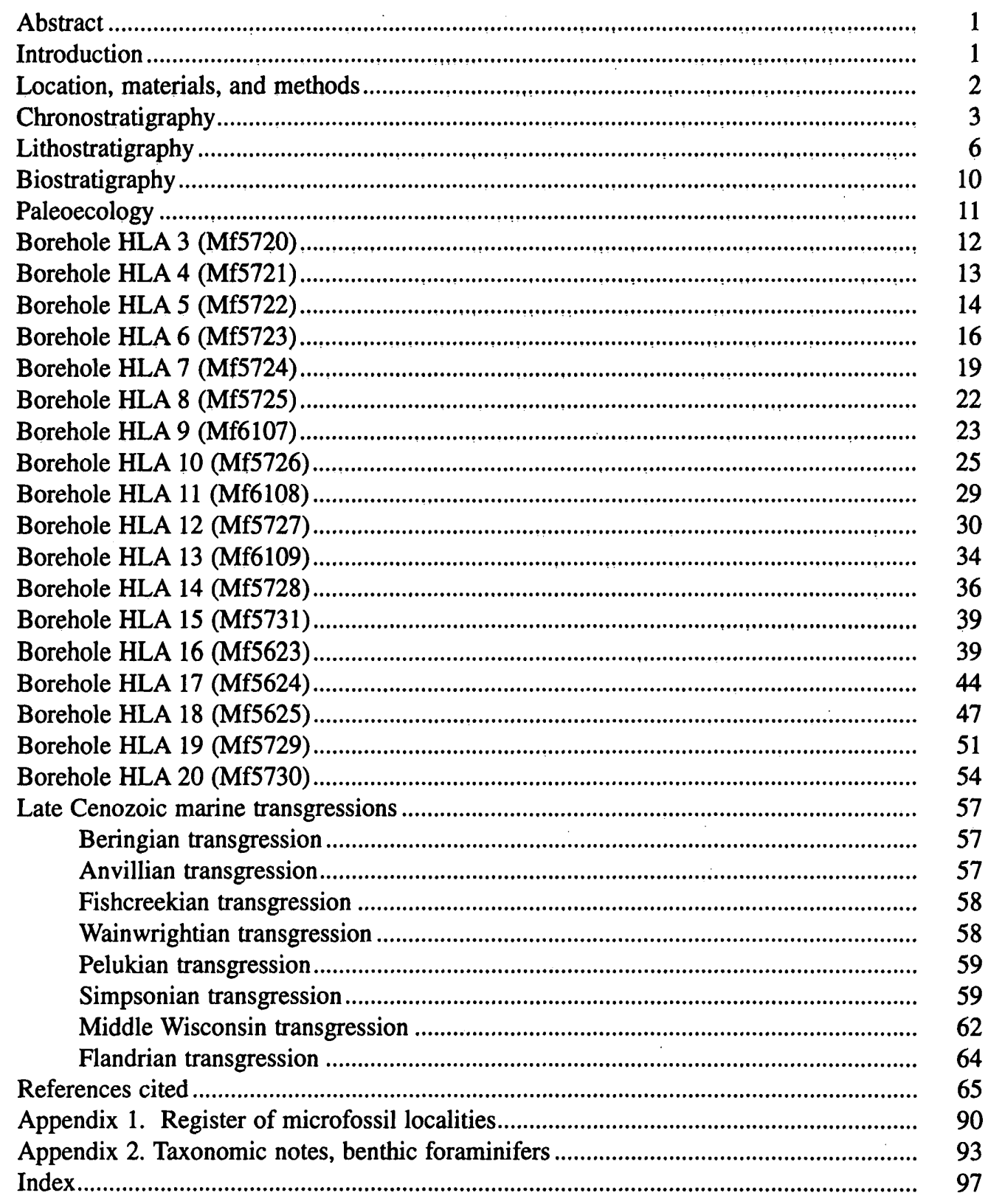

\section{PLATES}

[Plates follow Index]

1. Buccella, Cassidulina, Cibicides, Cyclogyra, Dentalina, Discorbis, Eggerella, Elphidiella? and Elphidiella

2. Elphidium

3. Fissurina, Fursenkoina, Glandulina, Gordiospira, Guttulina, Lagena, and Miliolinella

4. Melonis, Nonionella, Oolina, Pateoris, Polymorphina, Quinqueloculina, Reophax, Scutuloris, Spiroplectammina, Stainforthia, and Trochammina 


\section{FIGURES}

1. Map of Arctic Coastal Plain showing locations of HLA boreholes on Beaufort Sea shelf .....

2. Estimates of age ranges, sea-level changes, and climatic conditions of late Cenozoic marine transgressions in northern Alaskan compared to present conditions

3. Correlation of late Cenozoic northern Alaskan marine transgressions, Pacific and Atlantic warm and cold events, and sea-level curve, and paleomagnetic and standard chronographic time scales.

4. Composite lithostratigraphic section for nearshore HLA boreholes

5. Composite lithostratigraphic section for offshore HLA boreholes

6. Correlation of units in nearshore HLA boreholes

7. Correlation of units in offshore HLA boreholes

8. Lithology, sample locations, paleoenvironments, and ages of borehole HLA 3 .

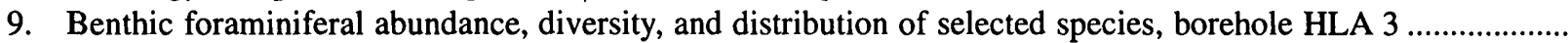

10. Lithology, sample locations, paleoenvironments, and ages of borehole HLA 4 .

11. Benthic foraminiferal abundance, diversity, and distribution of selected species, borehole HLA 4 ...................

12. Lithology, sample locations, paleoenvironments, and ages of borehole HLA 5 .

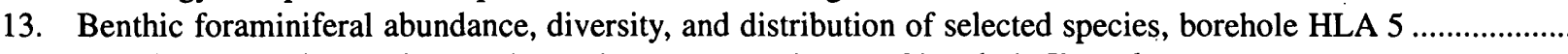

14. Lithology, sample locations, paleoenvironments, and ages of borehole HLA 6

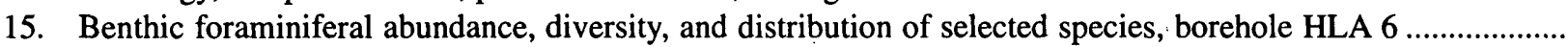

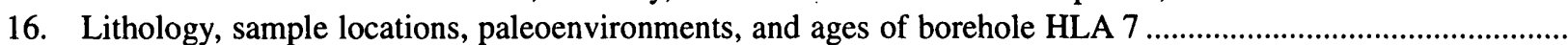

17. Benthic foraminiferal abundance, diversity, and distribution of selected species, borehole HLA 7 ..................

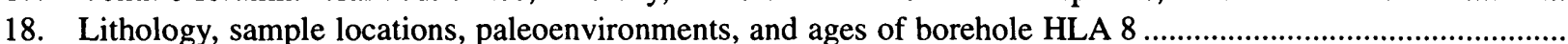

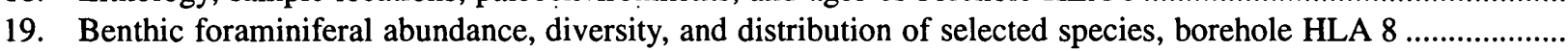

20. Lithology, sample locations, lithostratigraphic units, paleoenvironments, and ages of borehole HLA 9.............

21. Lithology, sample locations, lithostratigraphic units, paleoenvironments, and ages of borehole HLA 10..........

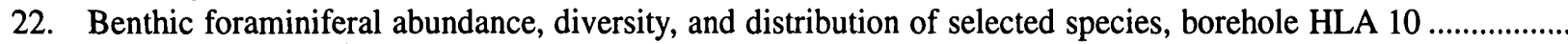

23. Lithology, sample locations, lithostratigraphic units, paleoenvironments, and ages of borehole HLA $11 \ldots \ldots . . . .$.

24. Benthic foraminiferal abundance, diversity, and distribution of selected species, borehole HLA 11..................

25. Lithology, sample locations, lithostratigraphic units, paleoenvironments, and ages of borehole HLA $12 \ldots \ldots . . . .$.

26. Benthic foraminiferal abundance, diversity, and distribution of selected species, borehole HLA 12 .................

27. Lithology, sample locations, lithostratigraphic units, paleoenvironments, and ages of borehole HLA 13..........

28. Benthic foraminiferal abundance, diversity, and distribution of selected species, borehole HLA 13 .................

29. Lithology, sample locations, lithostratigraphic units, paleoenvironments, and ages of borehole HLA 14..........

30. Benthic foraminiferal abundance, diversity, and distribution of selected species, borehole HLA 14 .................

31. Lithology, sample locations, lithostratigraphic units, paleoenvironments, and ages of borehole HLA 15..........

32. Benthic foraminiferal abundance, diversity, and distribution of selected species, borehole HLA 15 ................

33. Lithology, sample locations, lithostratigraphic units, paleoenvironments, and ages of borehole HLA 16..........

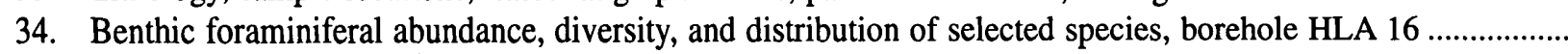

35. Lithology, sample locations, lithostratigraphic units, paleoenvironments, and ages of borehole HLA 17..........

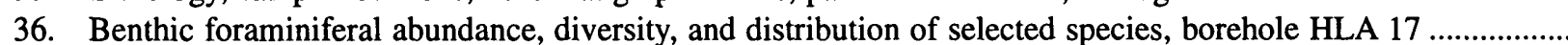

37. Lithology, sample locations, lithostratigraphic units, paleoenvironments, and ages of borehole HLA 18..........

38. Benthic foraminiferal abundance, diversity, and distribution of selected species, borehole HLA 18 .................

39. Lithology, sample locations, lithostratigraphic units, paleoenvironments, and ages of borehole HLA 19..........

40. Benthic foraminiferal abundance, diversity, and distribution of selected species, borehole HLA 19 .................

41. Lithology, sample locations, lithostratigraphic units, paleoenvironments, and ages of borehole HLA 20..........

42. Benthic foraminiferal abundance, diversity, and distribution of selected species, borehole HLA 20 .................

43. Distribution of benthic foraminiferal biofacies during maximum sea-level rise of Wainwrightian transgression

44. Cross section through offshore HLA boreholes showing distribution of Wainwrightian sediments and foraminiferal biofacies.

45. Distribution of benthic foraminiferal biofacies at beginning of Pelukian transgression.

46. Distribution of benthic foraminiferal biofacies during maximum sea-level rise of Pelukian transgression......... 
47-50. Cross sections through HLA boreholes showing:

47. Nearshore distribution of Pelukian sediments and foraminiferal biofacies ............................................. 62

48. Offshore distribution of Pelukian sediments and foraminiferal biofacies .............................................. 63

49. Nearshore distribution of Simpsonian and younger sediments and foraminiferal biofacies...................... 64

50. Offshore distribution of Simpsonian and younger sediments and foraminiferal biofacies ....................... 65

\section{TABLES}

[Tables 2-19 follow References Cited]

1. Species diagnostic of recent benthic foraminiferal biofacies ............................................................................ 11

2-19. Abundance and distribution of benthic foraminifers in:

2. Borehole HLA 3

3. Borehole HLA 4

4. Borehole HLA 5

72

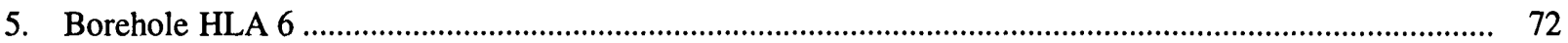

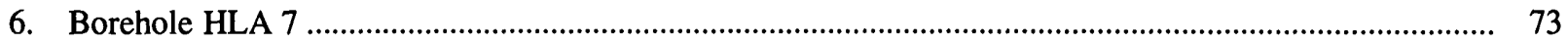

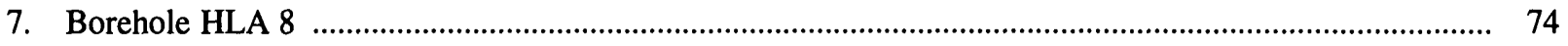

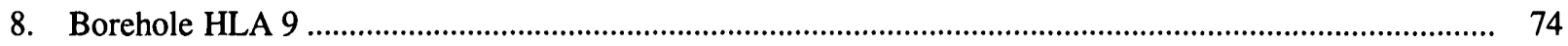

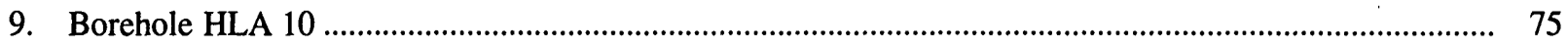

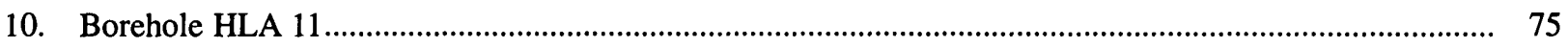

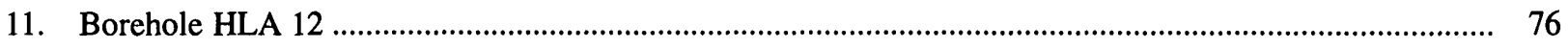

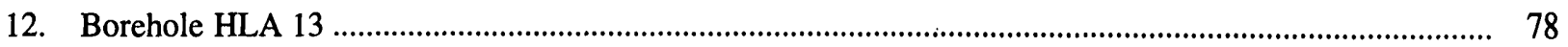

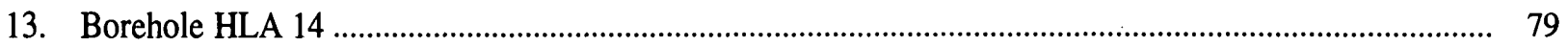

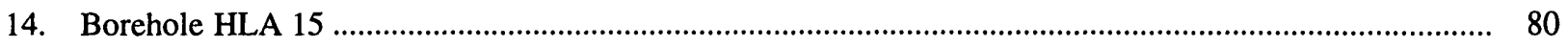

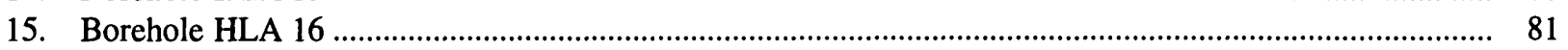

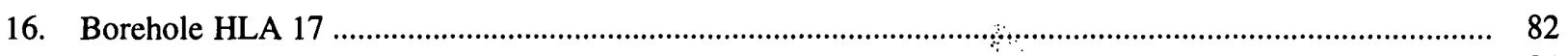

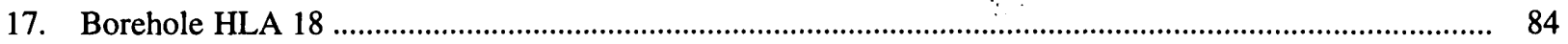

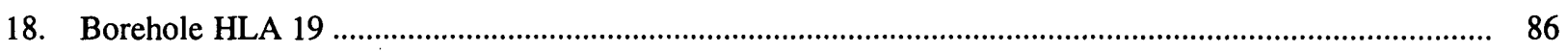

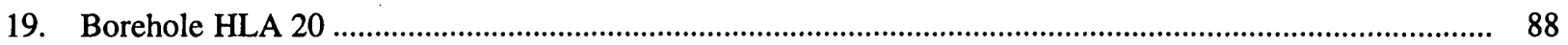





\title{
Late Cenozoic Benthic Foraminifers of the HLA Borehole Series, Beaufort Sea Shelf, Alaska
}

\author{
By Kristin McDougall
}

\begin{abstract}
Benthic foraminiferal faunas in 18 boreholes from the eastern Beaufort Sea shelf were examined. Foraminiferal data were integrated with sedimentologic, seismic, and other microfossil data to identify marine transgressions, to determine age, and to interpret paleoecologic conditions of the late Cenozoic on the Beaufort shelf. Eight marine transgressions ranging in age from Pliocene to Pleistocene were recognized: Beringian, Anvillian, Fishcreekian, Wainwrightian, Pelukian, Simpsonian, middle Wisconsin, and Flandrian. Foraminiferal assemblages associated with each of these transgressions indicate water depth, salinity, temperature, and downslope transport.

Sediments identified as Beringian, Anvillian, and Fishcreekian occur in one borehole (HLA 18). Questionable Fishcreekian sediments were encountered in two other boreholes. Foraminiferal assemblages associated with the Beringian and Anvillian transgressions in the HLA boreholes are too limited to suggest regional paleoecologic conditions during those transgressions. Assemblages from the Fishcreekian transgression indicate cooler water temperatures and greater water depths than at present; the foraminiferal assemblages also suggest considerable erosion and reworking of older material. Wainwrightian sediments and faunas are common in the boreholes. The Wainwrightian assemblages suggest that water depths were greater than at present and, for most of the time, water temperatures were warmer. Pelukian assemblages suggest that water depths were slightly greater and water temperatures were warmer than at present, whereas Simpsonian and middle Wisconsin assemblages suggest that water depths were the same to slightly greater and temperatures were slightly cooler than at present. Pelukian, Simpsonian, and middle Wisconsin sediments and faunas are strongly affected by river input. During the Pelukian and Simpsonian transgressions, the sedimentation rate and warmer low-salinity waters from the Sagavanirktok and Shaviovik Rivers either excluded the benthic foraminiferal faunas from the deltaic areas or extended the occurrence of
\end{abstract}

Approved for publication January 6, 1993. nearshore Elphidium-dominated biofacies into deeper waters along the channels in deltaic areas. Sediments sampled from the middle Wisconsin transgression were deposited in channels cut by the Sagavanirktok and Shaviovik Rivers on the Beaufort shelf. Faunas from the Flandrian transgression occur in a thin veneer of clay and silt, usually in the nearshore boreholes, and represent shallow inner neritic deposition or lag deposits. In addition to in situ species, the Flandrian lag deposits contain many reworked older species that represent the deeper marine conditions characteristic of the Pelukian or Simpsonian transgressions.

Faunas in the Beringian and Anvillian transgressions contain the age-diagnostic species Elphidium ustulatum, which ranges from the Pliocene to the Pleistocene throughout the circum-Arctic region. Abundant E. ustulatum in Fishcreekian assemblages suggest an early Pleistocene age (1.67-0.8 Ma). Age diagnostic species are not common in the younger transgressions. Elphidiella groenlandica, Elphidium asklundi, and E. incertum, which are present in Wainwrightian and Pelukian assemblages, decrease in abundance in the younger transgressions, where they appear primarily as reworked components. Elphidium excavatum alba is rare in Wainwrightian and Pelukian assemblages but becomes more common in the younger transgressions, where warmer water conditions prevail.

\section{INTRODUCTION}

Following the successful completion of eight shallow boreholes in Prudhoe Bay in 1977 and 1978, the U.S. Geological Survey, in association with Harding-Lawson Associates (HLA), participated in the study of 20 boreholes drilled on the Beaufort Sea shelf, Alaska (fig. 1). Core and wash samples from 18 of the boreholes were retained by the U.S. Geological Survey. Sediments were examined, described, and then subdivided for stratigraphic, geochronologic, and paleontologic studies. This paper describes the foraminiferal assemblages and interprets the age, environment, and stratigraphy of the HLA boreholes on the basis of benthic foraminifers. In several samples the foraminifers were absent or not diagnostic, so data from ostracodes was used. The Pliocene and Quaternary geologic history of the 
Beaufort shelf is discussed in light of these interpretations. Stratigraphic and lithologic data including interpretations of the lithologic facies, stratigraphic units, and relative age assignments from amino acid racemization, as well as integration with the seismic-reflector record of the Beaufort shelf, are from P.A. Smith, (1985a, b, and oral commun., 1984 through 1986). Ostracode interpretations are based on preliminary data provided by E.M. Brouwers (written communs., 1980 through 1986).

\section{LOCATION, MATERIALS, AND METHODS}

The 18 boreholes used for this study are on the Beaufort Sea shelf, northern Alaska (fig. 1). The boreholes are landward of the $15-\mathrm{m}$ isobath between the mouth of the Canning River and the eastern edge of the Jones Islands chain. Eleven boreholes are seaward of the barrier island chain, and seven are in the protected shallow waters landward of the island chain.

At the time of drilling, detailed lithologic logs were compiled for each of the 20 boreholes. The location and sample depths for each borehole except HLA 1 and HLA 2 are given in appendix 1 ; measurements of sea-ice thickness, depth to mudline (sediment-water interface), and total depth are also listed. Boreholes HLA 1 and HLA 2 were not sampled for microfossils, and no data are available. Depths used throughout this paper are meters below mudline unless otherwise indicated. Depth below mudline can be converted to depth below sea level by referring to appendix 1 . Lithology, sample locations, and stratigraphic and paleontologic interpretations of the borehole data are shown in figures 8 to 42 .

All microfossil samples were air dried or dried in an oven at low temperatures $\left(<50^{\circ} \mathrm{C}\right)$. Where available, $100 \mathrm{~g}$ (dry weight) of sediment was soaked for 4 to $12 \mathrm{hr}$ in water before being washed through a 230 -mesh screen ( 63 microns). Foraminifers, ostracodes, and representative amounts of associated organic material were picked from the washed residues. Foraminiferal species identified in these faunas are listed in appendix 2 and in tables 2 to 19 , where abundance is shown as a percentage of the total benthic foraminiferal fauna, which is the total number of specimens per $100 \mathrm{~g}$ of sediment. The abundances of selected species are graphed on figures 8 through 42 . Relative abundance terms for the number of specimens per sample and diversity terms used in this paper are "abundant" or "high" ( $>500$ specimens or $>20$ species), "common" or "moderate" (101-500 specimens or 11-20 species), "few" or "low" (10-101 specimens or 2-10

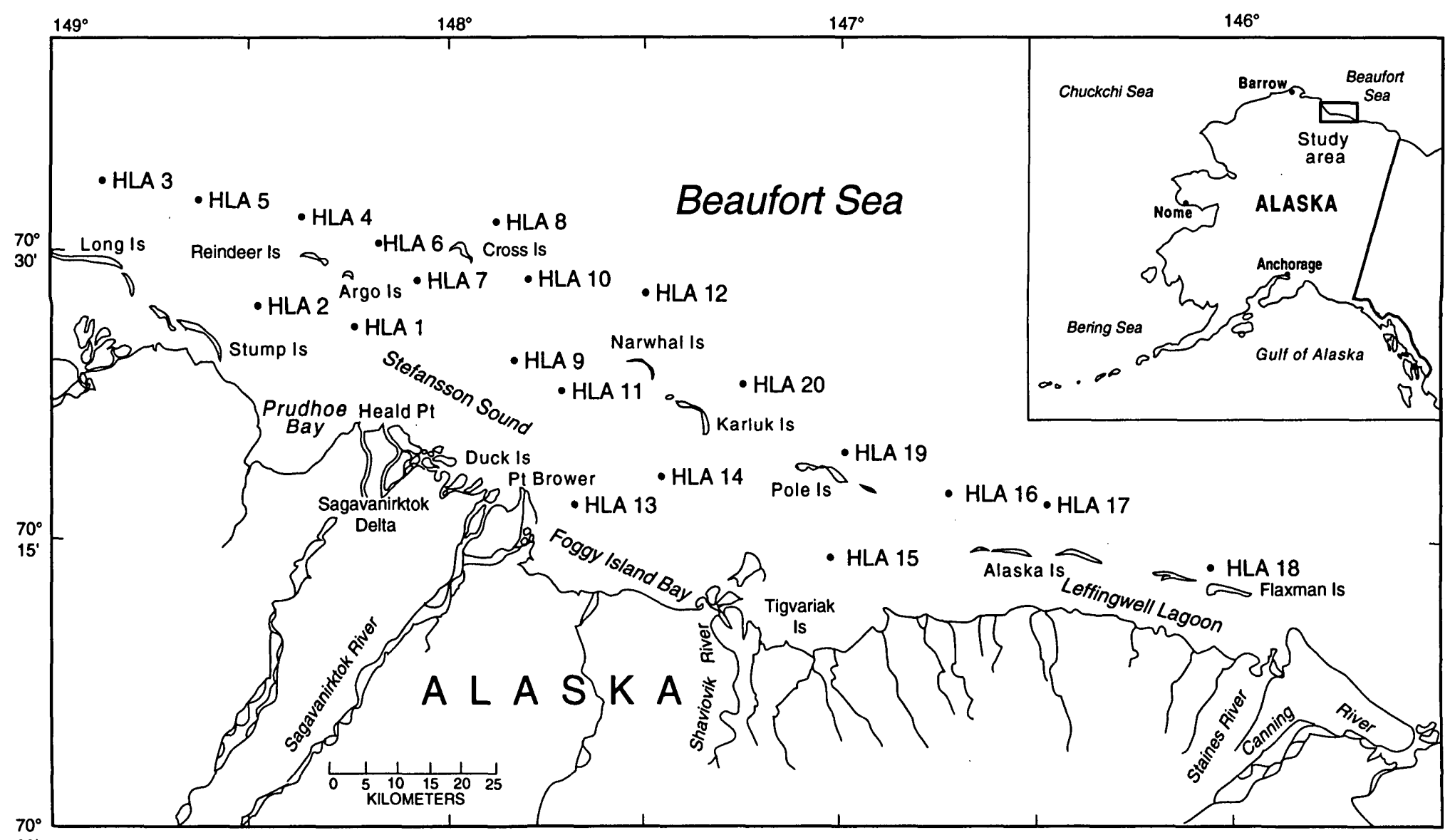

$0^{\prime}$

Figure 1. Arctic Coastal Plain showing locations of HLA boreholes (solid circles) on Beaufort Sea shelf, Alaska. 
species), and "rare" ( $<10$ specimens or 1 species). When discussing an individual fauna, the terms "abundant" $(>10 \%)$, "common" (6-10\%), "few" (1-5\%), and "rare" $(<1 \%)$ refer to the percentage of the total fauna in that sample. Foraminiferal slides and residues are on file with the Branch of Paleontology and Stratigraphy in Menlo Park, Calif. Ostracodes were examined by E.M. Brouwers, U.S. Geological Survey in Denver, Colo.; ostracode slides and preliminary reports are on file with the Branch of Paleontology and Stratigraphy.

\section{CHRONOSTRATIGRAPHY}

Late Cenozoic deposits of the Arctic Coastal Plain and adjacent Beaufort Sea shelf record a complex history of eustatic sea-level changes related to glacial advances and retreats. Glacial chronology developed to the south in the Brooks Range, Alaska, document four major glacial episodes: (1) the Gunsight Mountain glaciation (late Tertiary), (2) the Anaktuvuk River glaciation (Pliocene? and early Pleistocene), (3) the Sagavanirktok River glaciation (multiple advances, middle Pleistocene), and (4) the Itkillik glaciation (multiple advances, Wisconsin glacial stage, late Pleistocene) (Detterman and others, 1958; Hamilton and Porter, 1975; Hamilton and Hopkins, 1982; Hamilton, 1979, 1982, 1983, 1986; Thorson, 1986). The stratigraphic framework developed for the intervening interglacial stages and interstades is based on a sequence of marine transgressions identified in western Alaska and on islands in the Bering Sea and named by Hopkins $(1967,1973)$. Hopkins' scheme has been modified and refined by further study in northern Alas$\mathrm{ka}$ and by the development of new dating techniques (Brigham, 1985a, b; Brouwers and others, 1984; Carter and others, 1986a; Smith, 1985a, b). The chronostratigraphic framework used here was developed as a result of these Alaska studies and correlations with Pacific and Atlantic Pliocene and Pleistocene marine deposits (figs. 2, 3).

Northern Alaskan marine transgressions are (in order of decreasing age) Beringian, Anvillian, Fishcreekian, Wainwrightian, Pelukian, Simpsonian, middle Wisconsin, and Flandrian. The Beringian, Anvillian, and Pelukian transgressions were originally identified by Hopkins (1967) from deposits near Nome, in western Alaska, and from various deposits along the Alaskan coastline including the Beaufort Shelf. Carter and others (1986) proposed the names Colvillian and Bigbendian, which may correlate with the Beringian and Anvillian transgressions, respectively, to identify the two oldest transgressions on the Arctic Coastal Plain. Amino acid aIle/lle ratios from mollusks are generally required to differentiate the Colvillian and Bigbendian transgressions (Carter and Galloway, 1985). (These are ratios of D-alloisoleucine and $\mathrm{L}$-isoleucine amino acids in both the free or naturally hydrolyzed and total or free plus peptide-bound amino acid assemblage fractions; see Brigham, 1985.) The western Alaskan names are retained in this paper for the two

\begin{tabular}{|c|c|c|c|c|}
\hline \begin{tabular}{|l} 
\\
\\
\\
0 \\
\\
\end{tabular} & $\begin{array}{c}\text { MARINE } \\
\text { TRANSGRESSIONS }\end{array}$ & 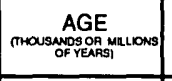 & $\begin{array}{c}\text { SEA-LEVEL } \\
\text { CHANGE } \\
\text { (MEERAS) } \\
\end{array}$ & CLIMATE \\
\hline \begin{tabular}{|l}
$\mathscr{8}$ \\
$\frac{8}{0}$ \\
$\frac{8}{0}$
\end{tabular} & Flandrian & $<18 \mathrm{ka}$ & $=$ Present & $=$ Present \\
\hline \multirow{4}{*}{ 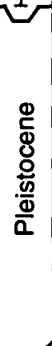 } & $\begin{array}{c}\text { Middle } \\
\text { Wisconsin }\end{array}$ & $24-50 \mathrm{ka}$ & $\pm 2 m$ & $\begin{array}{l}\text { Slightly } \\
\text { cooler }\end{array}$ \\
\hline & Simpsonian & $70-80 \mathrm{ka}$ & $+7 \mathrm{~m}$ & $\begin{array}{l}\text { Same to } \\
\text { slightly wamer }\end{array}$ \\
\hline & Pelukian & $125 \mathrm{ka}$ & $+7-10 \mathrm{~m}$ & $\begin{array}{c}\text { Air slightly } \\
\text { warmer; } \\
\text { water warmer }\end{array}$ \\
\hline & Wainwrightian & $>158-540 \mathrm{ka}$ & $+20-25 m$ & $\begin{array}{l}\text { Variable but } \\
\text { generally } \\
\text { wamer }\end{array}$ \\
\hline \multirow{3}{*}{ 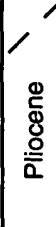 } & Fishcreekian & $1.0-<2.48 \mathrm{Ma}$ & $+25-35 \mathrm{~m}$ & $\begin{array}{c}\text { Air cooler; } \\
\text { water same to } \\
\text { slightly warmer }\end{array}$ \\
\hline & Anvillian & $2.0-<2.4 \mathrm{Ma}$ & $>35 \cdot<60 \mathrm{~m}$ & Warmer \\
\hline & Beringian & $3.0-<3.8 \mathrm{Ma}$ & $>40-<60 \mathrm{~m}$ & Warmer \\
\hline
\end{tabular}

Figure 2. Estimates of age ranges, sea-level changes, and climatic conditions of late Cenozoic marine transgressions in northern Alaskan compared to present conditions. Data from Hopkins (1967), McCulloch (1967), Brouwers and others (1984), Brigham (1985a, b), Smith (1985a, b), and Carter and others (1986a). Dashed line where uncertain.

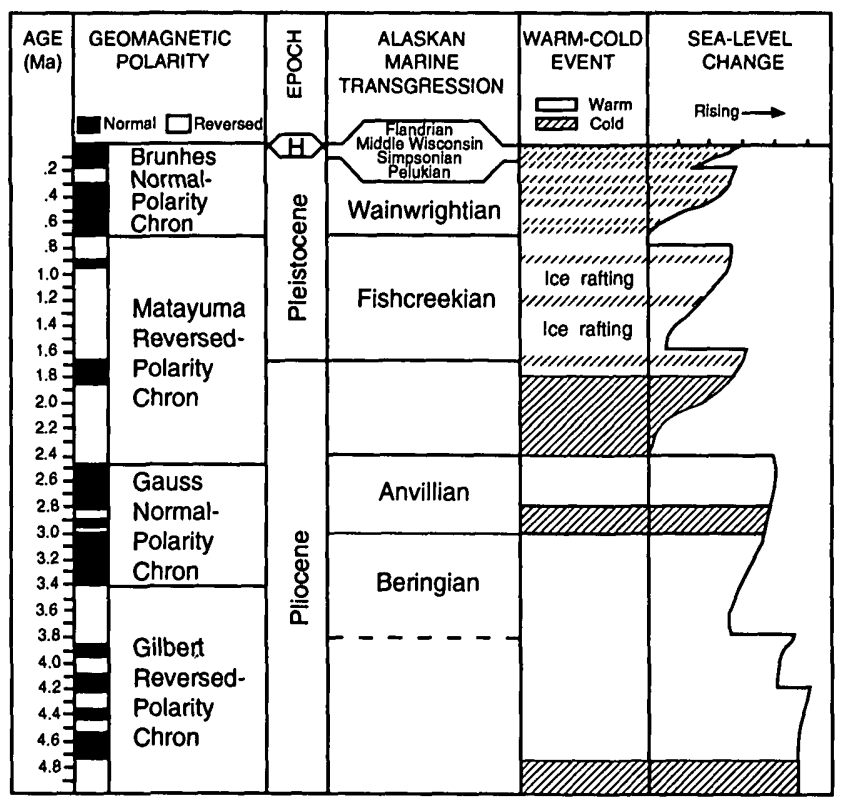

$\mathrm{H}-$ Holocene

Figure 3. Correlation of late Cenozoic northern Alaskan marine transgressions (Hopkins, 1967, 1973; Carter and others, 1979, 1986a), the Pacific and Atlantic warm and cold events (Kent and others, 1971; Shackleton and Opdyke, 1973, 1976, 1977; Keller, 1978; Berger, 1982; Keller and Barron, 1983), relative sea-level curve (Haq and others, 1987), and paleomagnetic and standard chronographic time scales. Ma, million years; $\mathrm{H}$, Holocene. Dashed line where uncertain. 
oldest transgressions. Fishcreekian, Wainwrightian, and Simpsonian are names proposed by Carter and others (1979, 1986a). The Fishcreekian transgression is represented by marine deposits that were not previously recognized from the Chukchi and Beaufort Sea coasts in western Alaska (P.A. Smith, written commun., 1986). The Wainwrightian transgression identified by Carter and others (1986a) is probably a composite of transgressions that include most deposits previously assigned to the Kotzebuan transgression of western Alaska (P.A. Smith, written commun., 1986). Sediments and faunas from the Arctic Coastal Plain identified as Kotzebuan have a broad range of absolute and relative ages. Sediments dated as $158 \mathrm{ka}$ (Carter and Galloway, 1985) along the south shore of the Kogru River southeast of Barrow may be part of the same high stand as those of the Kotzebuan transgression of Hopkins (1967), whereas the Karmuk unit near Wainwright (540 ka; Brigham, 1985a, b) and sediments at Cape Simpson (209 ka; Brigham, 1985a, b), both southwest of Barrow, represent older high stands within the same transgression. Because the sediments and faunas are similar, the Wainwrightian transgression is envisioned as a major transgression that spans a broad range of time with numerous eustatic sea-level changes. The Kotzebuan transgression (170-175 ka) of Hopkins (1967) probably represents a young high sea-level stand within the Wainwrightian transgression.

Criteria and definitions of the Simpsonian, middle Wisconsin, and Flandrian transgressions were discussed in an earlier study (McDougall and others, 1986). Briefly, the Simpsonian transgression (Carter and others, 1986a) occurred near the end of the Sangamon interglaciation and continued into the early Wisconsin; the middle Wisconsin transgression occurred between the Itkillik I and Itkillik II glaciations during the Wisconsin glacial interval; and the Flandrian transgression followed the late Wisconsin glacial maxima. Climatic conditions and sea-level changes are summarized in figure 2 , are discussed in the original references, and are summarized by McDougall and others (1986) and Smith (1985a, b).

Opinions differ over the ages of these marine transgressions. The chronostratigraphic framework developed for this paper correlates the Alaskan marine transgressions with widespread climatic events that have been recognized in the Pacific and Atlantic Oceans and relies on absolute and relative age determinations from paleomagnetic, potassium-argon (K-Ar), thermoluminescence (TL), and amino acid racemization (A) data. Amino acid analyses cited in this publication were performed at the Amino Acid Laboratory, INSTAAR, University of Colorado, Boulder, Co1o. (P.A. Smith, written commun., 1986), and are based on the foraminifers Elphidium clavatum and Elphidium orbiculare. Amino acid stratigraphy is discussed more fully in Brigham (1985a, b). Extinctions or evolutionary trends of organisms were used whenever possible to determine the age of the transgressions in this paper. Faunal composition, ecologic interpretations, and Arctic first and last ap- pearances that are primarily controlled by climatic conditions were also considered.

Cold events of worldwide importance are noted at approximately 5.2 to $4.7,3.0$ to $2.8, \pm 2.4$ to $1.8,1.3$ to $1.2,0.9$, and $0.7 \mathrm{Ma}$ (Kent and others, 1971; Shackleton and Opdyke, 1973, 1976, 1977; Keller, 1978; Berger, 1982; Keller and Barron, 1983; Shackleton and Hall, 1984; Shackleton and others, 1984) (fig. 3). Numerous short cold events have occurred since $0.7 \mathrm{Ma}$. The intervening warm events can be described relative to the present conditions. The early Pliocene warm event, 4.7 to $3.0 \mathrm{Ma}$, was a period of warm water temperatures (Keller, 1978), and no ice accumulated in the Northern Hemisphere from 3.5 to $3.2 \mathrm{Ma}$ (Shackleton and Opdyke, 1977). The late Pliocene warm event (2.8 to \pm 2.4 $\mathrm{Ma}$ ) was slightly cooler than the preceding event but warmer than at present (Keller, 1978) and was terminated by the onset of Northern Hemisphere glaciation at about 2.4 Ma (Shackleton and Hall, 1984; Shackleton and others, 1984). Temperatures during the early Pleistocene warm event $(1.8-0.7 \mathrm{Ma})$ were cooler than at present (Jansen and others, 1989). Termination of major ice accumulation was highly variable following the cold event (2.4-1.8 Ma), and short glacial intervals were common from 1.8 to $1.2 \mathrm{Ma}$. Low-amplitude oxygen isotope changes imply more uniform, cool temperatures during this event than during previous warm events (Shackleton and Opdyke, 1977). Short intense cold events at 1.3 to $1.2,0.9$, and $0.7 \mathrm{Ma}$ mark the end of this quiescent period (Berger, 1982). The change in climatic conditions may be related to the onset of midlatitude glaciation (Kent and others, 1971). The interval between 0.7 Ma and the present consists of a series of warm events interrupted by short intense cold events that correspond to the even-numbered oxygen isotope stages of Shackleton and Opdyke (1973, 1976, 1977). The warm events, corresponding to isotope stages 5 and 1 , are commonly known as the Sangamon interglaciation stage and the Holocene, respectively.

The Beringian transgression occurred during the Gauss Normal-Polarity Chron (3.40-2.48 Ma) on the basis of paleomagnetic data (Hopkins, 1967). The lower age limit of the Beringian transgression was originally constrained by the first occurrence of North Pacific mollusks in the North Atlantic, dated at 3.0 Ma (Einarsson and others, 1967; Gladenkov, 1981) and indicating the opening of the Bering Strait (Hopkins, 1967). The lower age limit of the Beringian transgression has subsequently been estimated as less than 3.8 Ma (aminozone 5, Brigham, 1985a, b) and less than $3.5 \mathrm{Ma}$ (Colvillian transgression of Carter and Galloway, 1985; Carter and others, 1986a). An upper age limit of 2.2 Ma (Hopkins, 1967) was based on a lava flow overlying sediments of the second Beringian transgression on St. George Island in the Bering Sea (Hopkins and others, 1974; Repenning, 1983; Brouwers and others, 1984). The second Beringian transgression is now recognized as the Anvillian transgression; thus the upper limit of the Beringian is unknown but is prior to $2.2 \mathrm{Ma}$. Molluscan faunas in the Atlantic (Einarsson and 
others, 1967; Gladenkov, 1981) suggest warm climatic conditions during the Beringian; thus the upper limit is assumed to be prior to the cold event at 3.0 to $2.8 \mathrm{Ma}$. Given these data, the Beringian transgression is correlated with the latter part of the early Pliocene warm event ( 3.0 to about $3.8 \mathrm{Ma}$ ).

Potassium-argon ages on lava flows overlying sediments of the Anvillian transgression (second Beringian transgression on St. George Island) indicate an upper age limit of 2.2 to $2.0 \mathrm{Ma}$ for this transgression (D.M. Hopkins in Brouwers and others, 1984; Carter and others, 1986a). A lower age limit of less than 2.4 Ma was proposed by Repenning (1983) on the basis of marine mammals in an exposure of the Anvillian (Bigbendian) sediments at Ocean Point on the Colville River. The stratigraphic placement of these mammals is in question because one of the specimens was found as float (Carter and Galloway, 1985) and because subsequent amino acid analysis has indicated the presence of two transgressions at Ocean Point (Carter and others, 1986a). The K-Ar and amino acid ages and the warm faunas (Repenning, 1983; Carter and others, 1986a) and floras (Nelson, 1981; Nelson and Carter, 1985s) suggest correlation of the Anvillian transgression with the late Pliocene warm event (2.8-2.4 Ma).

Amino acid ages indicate that the Fishcreekian transgression occurred between 2.48 to $1.5 \mathrm{Ma}$ (Carter and others, 1986a) and 1.4 to $1.0 \mathrm{Ma}$ (aminozone 3, Brigham, 1985a, b). An age of $1.2 \mathrm{Ma}$ was proposed on the basis of a correlation between deposits at Skull Cliff west of Barrow and on the Pribilof Islands in the Bering Sea (D.M. Hopkins in Brouwers and others, 1984). An age of $2.4 \mathrm{Ma}$, based on proposed vertebrate and ostracode lineages, was suggested by Repenning and others (1987). Their age interpretation is not accepted here, however, as the lineages used to determine the age were based on the assumption that the Fish Creek section (south of Harrison Bay between Barrow and the study area) was late Pliocene in age and that the problems of reworking and environmental control were insignificant. Strontium isotope analyses of deposits at Fish Creek and at Skull Cliff suggest an age range of 1.7 to $0.5 \mathrm{Ma}$ (Kaufman and others, 1990). Paleomagnetic study of the Fish Creek beds (Carter and Galloway, 1985) show that the basal part has normal magnetic polarity (result considered questionable by Carter and others, 1986a) and that the remainder of the section has reversed magnetic polarity. On the basis of amino acid ratios, strontium isotopes, and paleomagnetic data, deposition of the Fishcreekian sediments probably occurred during the Matuyama Reversed-Polarity Chron and correlates with the latest Pliocene to early Pleistocene warm event (1.8$0.7 \mathrm{Ma}$ ). Correlation of foraminiferal faunas from the type Fishcreekian deposits with faunas from the Beaufort-Mackenzie Basin, Canada (McNeil, 1989), suggests a latest Pliocene to early Pleistocene age $(1.8-0.7 \mathrm{Ma})$ based on the occurrence of Elphidium ustulatum and other age-diagnostic species (McDougall, unpub. data). The faunas, floras, and sediments suggest that air temperatures were cold, while water temperatures were warm (Carter and others, 1986b;
Repenning and others, 1987). Carter and others (1986b) believe that the limit of seasonal sea ice was at or north of their Fish Creek and Ocean Point localities and that perennial sea ice was severely restricted or absent. Striated boulder pavements at Skull Cliff are interpreted by Hopkins (in Carter and others, 1986b) as the result of stranded icebergs. Benthic foraminiferal faunas indicate that water temperatures were only slightly warmer than at present. Worldwide cool temperatures are also suggested for this warm event (Gartner, 1988; Jansen and others, 1989).

The Wainwrightian transgression appears to represent multiple transgressions or high sea-level stands (P.A. Smith, written commun., 1986). Ages from Wainwrightian deposits range from 540 to greater than 158 ka (Hopkins, 1967; aminozone 2, Brigham, 1985a, b; Brouwers and others, 1984; Carter and Galloway, 1985; Carter and others, 1986a; P.A. Smith, written commun., 1986). Strontium isotope analysis of Wainwrightian deposits at Skull Cliff suggest an age range of 1.1 to $0.3 \mathrm{Ma}$ (Kaufman and others, 1990). The Wainwrightian transgression correlates with the rapidly oscillating glacial-interglacial cycles occurring between 0.7 and about $0.2 \mathrm{Ma}$ (oxygen isotope stages 18 to 6 of Shackleton and Opdyke, 1976). Sediments corresponding to the 0.9- to 0.7-Ma warm interval have not yet been identified in Alaska and may be lumped with the underlying Fishcreekian or overlying Wainwrightian sediments.

The Pelukian and Simpsonian transgressions have been previously recognized as correlative with the Sangamon interglacial stage and oxygen isotope stage 5 (Hopkins, 1982; Carter and others, 1986a). Ages given for the Pelukian transgression are 130 to $100 \mathrm{ka}$ (Hopkins, 1973), 140 to $108.5 \mathrm{ka}$ with an average of $125 \mathrm{ka}$ (Carter and others, 1986a), 134 to $119 \mathrm{ka}$ with an average of $124 \mathrm{ka}$ (L.D. Carter in Carter and Ager, 1989), $125 \mathrm{ka}$ (aminozone 1, Brigham, 1985a, b), and 0.7 to $0.0 \mathrm{Ma}$ (Kaufman and others, 1990). Ages given for the Simpsonian transgression are 86 to $50 \mathrm{ka}$ (thermoluminescence analysis, Carter and others, 1986a; Carter and Ager, 1989), 75 ka (uranium series, J.L. Bischoff in Carter and others, 1986), and an average age of $70 \mathrm{ka}$ (Carter and others, 1986a).

An unnamed middle Wisconsin transgression is recognized in several areas on the Arctic Coastal Plain (McDougall and others, 1986; Carter and Ager, 1989) between the end of the Itkillik I glaciation at $60 \mathrm{ka}$ and the beginning of the Itkillik II glaciation at $25 \mathrm{ka}$ (Hamilton, 1986). Ages for this transgression are 48 to $41.5 \mathrm{ka}$ (thermoluminescence analysis, Carter in Carter and Ager, 1989) and $29.39 \pm 0.24 \mathrm{ka}$ (radiocarbon analysis, Carter and Ager, 1989). The assumed age of 50 to $24 \mathrm{ka}$ (McDougall and others, 1986) for the middle Wisconsin transgression correlates with the slight warming observed in oxygen isotope stage 3 (64-32 ka; Shackleton and Opdyke, 1976).

The correlations summarized in figures 2 and 3 are the chronostratigraphic framework upon which this study is based. Lithostratigraphic and biostratigraphic criteria for 
recognizing the transgressive units were developed as a result of previously published papers (McDougall and others, 1986; Smith, 1985a, b) and numerous unpublished reports by McDougall and E.M. Brouwers (1980 to 1986).

\section{LITHOSTRATIGRAPHY}

The sediments exposed in the eastern boreholes (HLA 13 to HLA 20) were divided into 12 informally named sedimentary units ranging in age from Pliocene to Holocene (P.A. Smith, 1985a; written commun., 1986). These sedimentary units have been tentatively assigned to boreholes HLA 9 through HLA 12 (P.A. Smith, written commun., 1986). Although sediments in boreholes HLA 3 to HLA 8 are illustrated and discussed, sedimentary units were not determined for these boreholes by Smith. The lithology, distribution, and age of these sedimentary units as determined by Smith (1985a, b; written commun., 1986) is summarized below. Seismic analyses and the resulting paleogeographic interpretations are summarized from Wolfe and others $(1985,1986)$.

Sedimentary unit boundaries are defined on the basis of erosional features apparent on seismic profiles, evidence of disconformities in core samples, or changes in lithology. Often two or more of these characters are present at or near unit boundaries. The general age of each unit was determined by amino acid alle/Ile ratios from foraminiferal tests (Elphidium clavatum and E. orbiculare), by comparisons of the relative sea level to worldwide sea-level curves, by the presence or absence of ice-bonded permafrost, and by the degree of sediment compaction. The sedimentary units were given informal names (Smith, 1985a) and represent subdivisions of the Gubik Formation of northern Alaska.

Eight of the sedimentary units are marine (Camden Bay, Brunlow Point, Staines River, Leffingwell Lagoon, Maguire Islands, Cross Island, Mikkelsen Bay, and Stefansson Sound units), while the remaining four are nonmarine (North Star, Newport, and Duchess sand units, and Shaviovik gravel unit) (figs. 4, 5). The marine units range from beach sands and gravels to clay and silty clay. Nonmarine units are dominated by sand, sandy gravel, and gravels. Silt and clayey silt are present but rare in the nonmarine units (figs. 4, 5). Distribution and correlation of the sedimentary units in the boreholes are shown in figures 6 and 7.

The oldest marine units, the Camden Bay and Brunlow Point units, occur only in borehole HLA 18 (Smith, 1985a; fig. 7). The Camden Bay unit is represented by olive-black shelly clay and black, fine to coarse sand. An abrupt change to sandy gravel marks the upper boundary of this unit. The overlying Brunlow Point unit consists of clayey silt ranging in color from olive black or black at its base to dark greenish gray at its top. The basal $0.6 \mathrm{~m}$ of the unit contains abundant gravel and wood fragments and is interpreted as a beach facies. Occasional pebbles, rare shell fragments, and thin lenses of fine sand occur throughout the unit. Both the Camden Bay and Brunlow Point units represent shallow marine deposition. Smith (1985b) proposed a late Pliocene age for the Camden Bay unit and a late Pliocene to early Pleistocene age for the Brunlow Point unit. These units were correlated with the Beringian and Anvillian transgressions of Hopkins (1967). A sample (18-34) submitted for amino acid racemization analysis

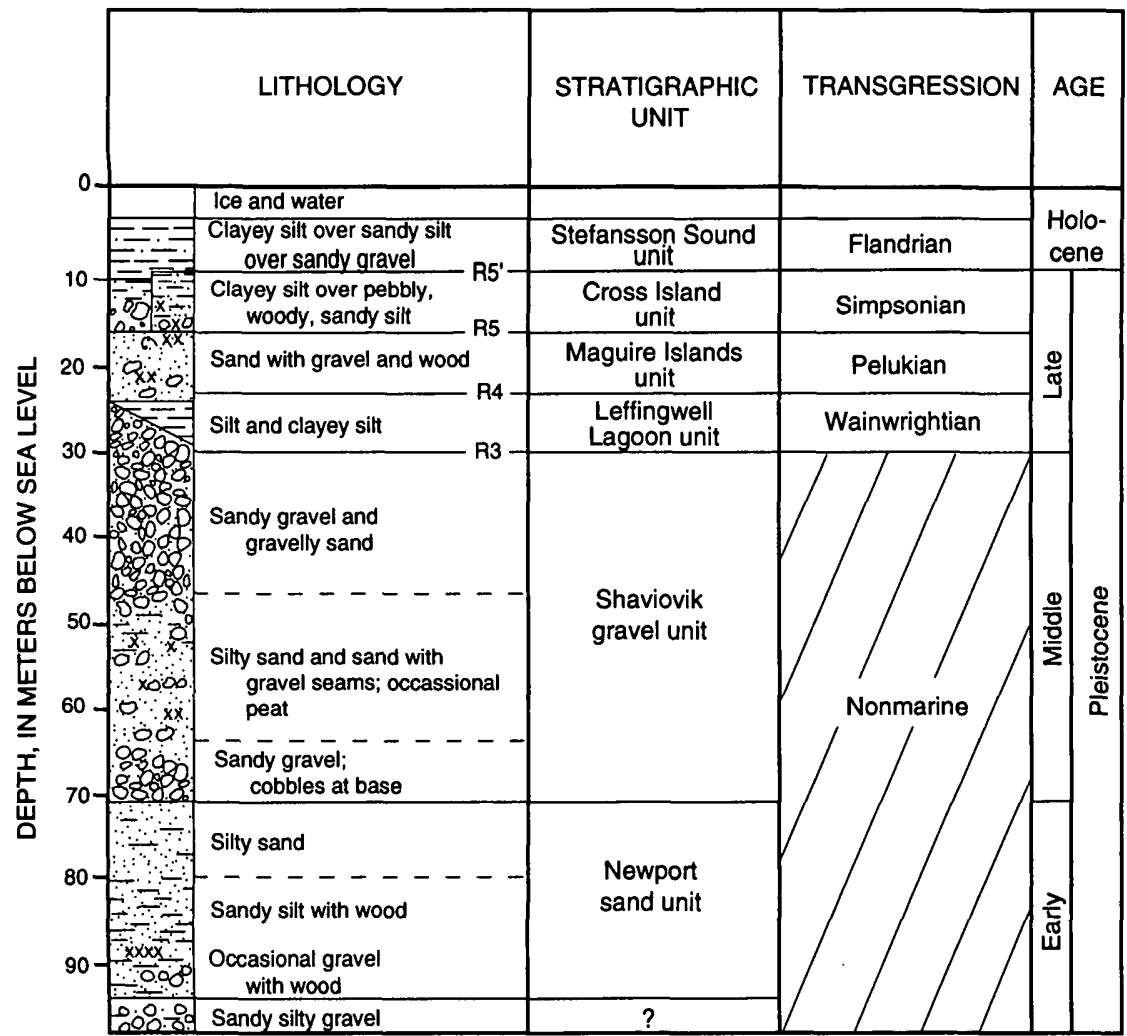

Figure 4. Composite lithostratigraphic section for nearshore HLA boreholes, Beaufort Sea shelf, Alaska. Dashed lines where approximate. R, seismic reflector surface (see Wolf and others, 1985). (From P.A. Smith, written commun., 1986.) 
yielded an alle/lle ratio of 0.113 (aminozone 4 of Brigham, 1985a), attesting to the old age of the Brunlow Point unit.

The North Star sand unit is $18 \mathrm{~m}$ thick in borehole HLA 18 and at least $39.2 \mathrm{~m}$ thick in HLA 12 (figs. 5, 34). This unit is composed of silty sand with seams of clayey silt, peat, and detrital wood. Minor gravel lenses occur near the base in HLA 18 and near the top in HLA 12. The upper boundary of the North Star sand unit in both HLA 12 and
HLA 18 is placed at the change from sand to clayey silt or silt (Staines River unit). The North Star sand unit is believed to be late Pliocene to early Pleistocene in age, as it occurs between marine units interpreted as late Pliocene to early Pleistocene in age. The North Star sand unit may correlate with the Newport sand unit.

The Newport sand unit, found only in the nearshore borehole HLA 15, is composed of approximately $22 \mathrm{~m}$ of

Figure 5. Composite lithostratigraphic section for offshore HLA boreholes, Beaufort Sea shelf, Alaska. (From P.A. Smith, written commun., 1986). Qf, unnamed sediments of Flandrian transgression. $\mathrm{R}$, seismic reflection surface.
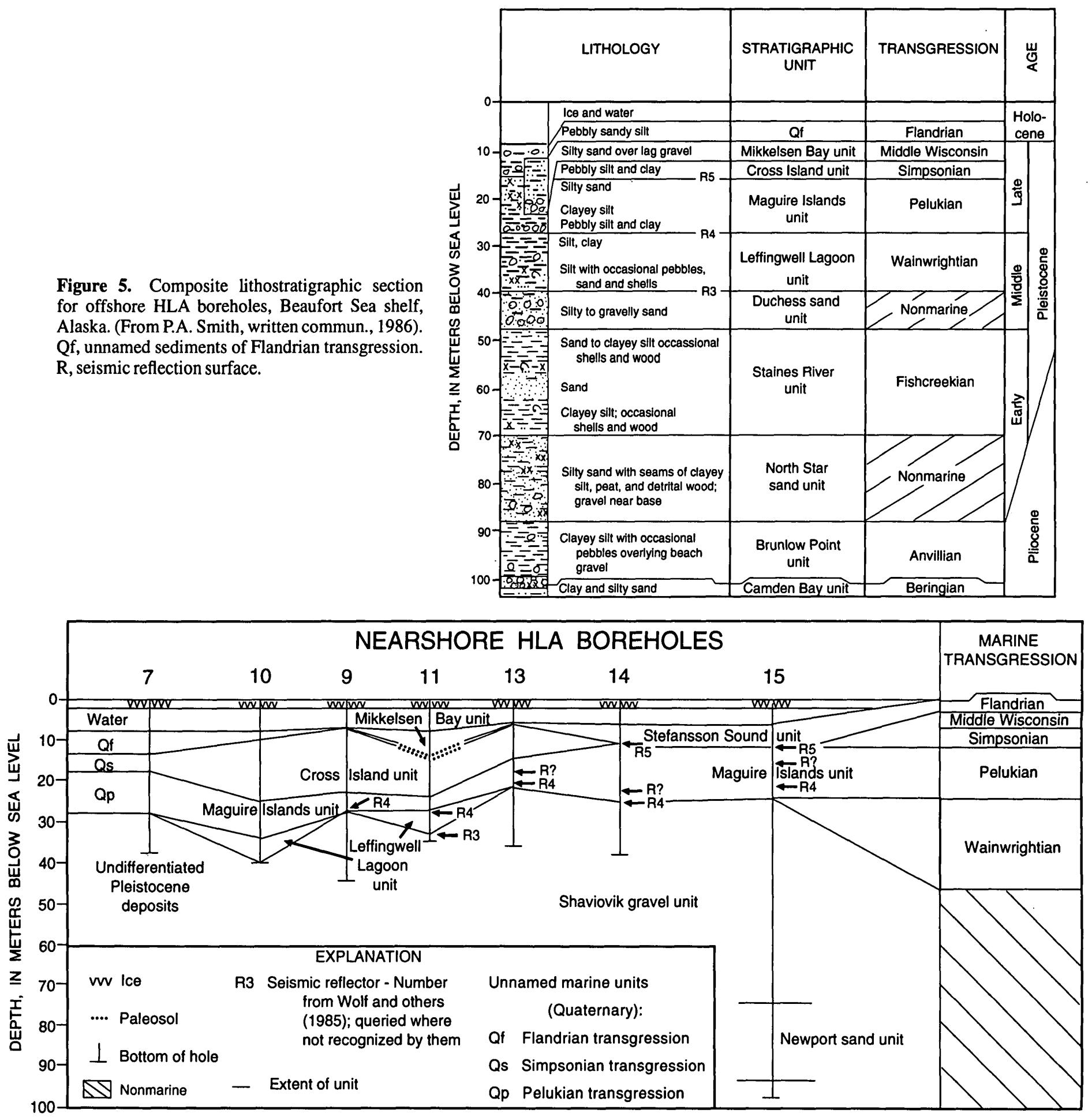

Figure 6. Correlation of lithostratigraphic units in nearshore HLA boreholes, Beaufort Sea shelf, Alaska. R, seismic reflection surface. 


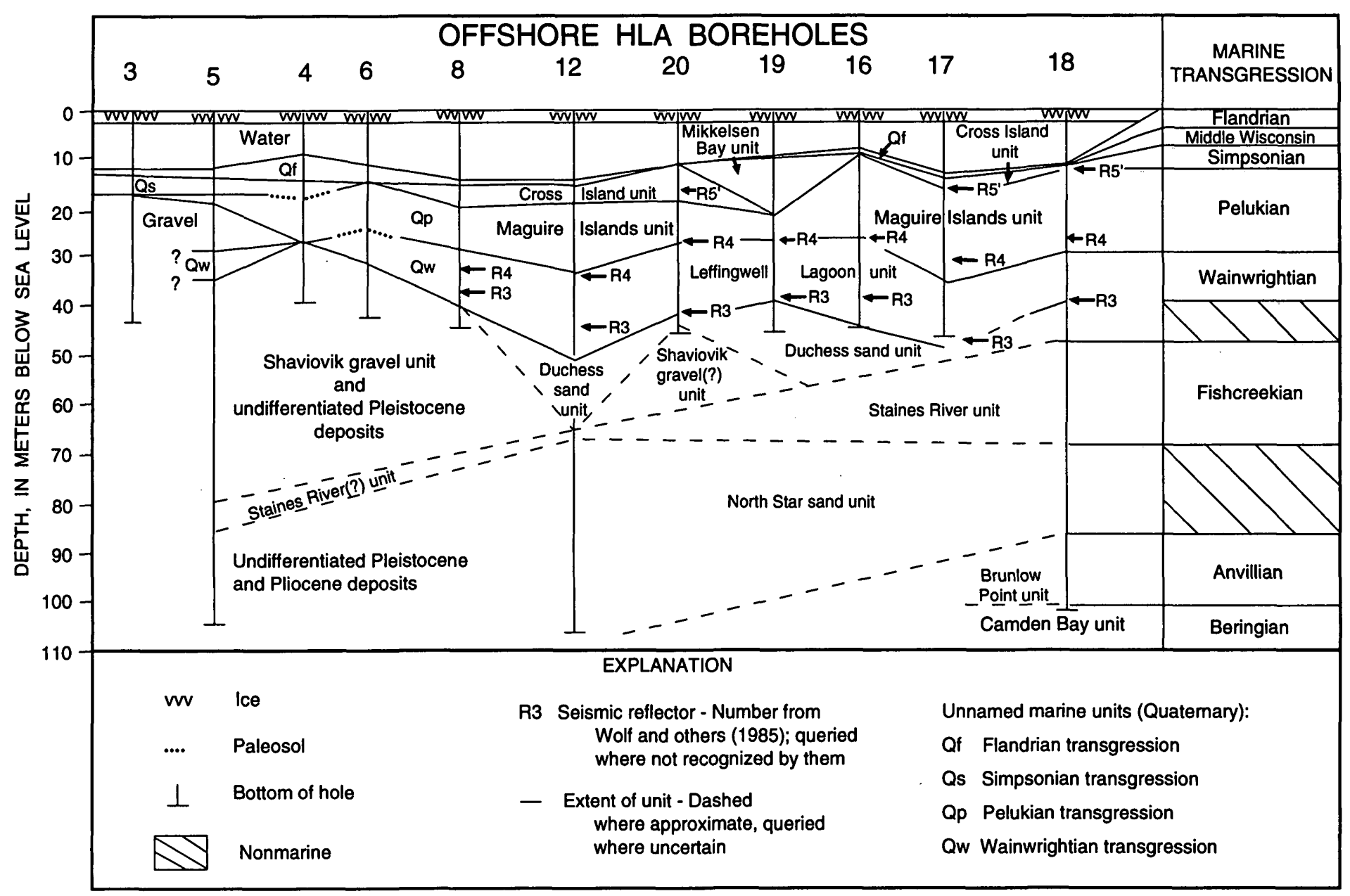

Figure 7. Correlation of lithostratigraphic units in offshore HLA boreholes, Beaufort Sea shelf, Alaska. R, seismic reflection surface.

silty sand and sandy silt with woody fragments. The lower boundary was not observed, and the upper boundary approximates the change from sand (Newport sand unit) to cobble-sized material (Shaviovik gravel unit). Both the Newport sand and North Star sand units are interpreted as alluvium and are believed to have been deposited during a low stand of sea level.

The next oldest marine unit, the Staines River unit, overlies the nonmarine North Star sand unit in both HLA 18 and HLA 12 (Smith, 1985a; fig. 7). Sediments questionably assigned to the Staines River unit in HLA 5 overlie sands and gravels identified by Smith as "undifferentiated Pleistocene and Pliocene." In HLA 18, the Staines River unit is $21.7 \mathrm{~m}$ thick and consists of a layer of fine sand and sandy silt that separates lower and upper layers of clayey silt; woody fragments occur near the base. In HLA 12, only the silty sand and sandy silt layer is present. Shell fragments are scattered throughout the Staines River unit, which was deposited during a time of fluctuating sea level. Higher sea levels are reflected by the finer sediments at the base and top, whereas lower sea levels are represented by the somewhat coarser sediments in the middle part of the unit. Alternative explanations for the coarser material are (1) a greater influx of sand from an ancestral Canning or Staines River or (2) shoaling and development of a barrier island system similar to that seen today (P.A. Smith, oral commun., 1985).

Two amino acid racemization analyses were run on sample 18-28 from the Staines River unit. AIle/Ile ratios ranging from 0.096 to 0.113 (aminozones 3 and 4 of Brigham, 1985a) were obtained from the benthic foraminifer Elphidium clavatum. Examination of the specimens from this sample and other samples used for amino acid analyses indicates that the higher ratio results when poorly preserved, reworked specimens are included. The higher ratio is, therefore, not accepted. Two additional analyses from a shallow marine mollusk, Portlandia, found near sample $18-28$ yielded ratios of 0.30 to 0.36 . Because rates of racemization in mollusks and foraminifers are different, the results should not be compared directly. Nevertheless, both groups indicate a relatively old age for the unit. The Staines River unit is believed to be early Pleistocene in age and correlates with the Fishcreekian transgression of Carter and others (1986a).

The next youngest nonmarine unit is the Duchess sand unit (fig. 5), which is present in boreholes HLA 12, 18, 19, 20 and possibly HLA 8. The thickness of this unit varies from $14.3 \mathrm{~m}$ in HLA 12 to $4.0 \mathrm{~m}$ in HLA 20. The unit is composed of dark- 
gray silty fine sand overlain by grayish-black silt. Deposition of the sand is believed to have occurred in a thaw lake, and the silts probably represent fluvial or alluvial deposition. No age estimates are available for the Duchess sand unit. It overlies an early Pleistocene marine unit, but whether the contact is conformable or erosional is not clear from the sediments. Seismic data from the inner Beaufort Sea shelf do not provide any useful information about the nature of the lower boundary. A tentative age of middle Pleistocene is assigned.

The Shaviovik gravel unit is found in most of the nearshore boreholes (fig. 6), and gravel is the primary constituent. The recorded thickness of the unit varies from $3.8 \mathrm{~m}$ in HLA 11 to $50.1 \mathrm{~m}$ in HLA 15. The base of this unit was only reached in borehole HLA 15 , so other thicknesses represent a minimum. The Shaviovik gravel unit may correlate in part with the Duchess sand unit.

The Leffingwell Lagoon unit (figs. 4 and 5) is the oldest marine unit in most of the eastern offshore boreholes, where it ranges in thickness from $17.2 \mathrm{~m}$ in HLA 12 to $10.5 \mathrm{~m}$ in HLA 17 (fig. 7). The base of the unit was not reached in borehole HLA 17 and, according to seismic records, is about $2 \mathrm{~m}$ below the bottom of the hole. The Leffingwell Lagoon unit is represented by a much reduced section in the nearshore boreholes HLA 10 and HLA 11 (fig. 6) where it is approximately $5.8 \mathrm{~m}$ thick. The basal part of the unit is a lag or beach deposit of sand with peat, gravel, and shell fragments. The remainder of the unit is composed of micaceous silt and clayey silt. Shell fragments, sandy layers, and pebbles are present in the silt. The pebbles occur more frequently near the top of the unit and may indicate ice rafting.

Seismic reflector R3 (surface 3 of Wolf and others, 1985) occurs at or within a few meters of the base of the Leffingwell Lagoon unit in all holes having that unit. This reflector is the strongest and most widespread reflector on the inner Beaufort shelf and can be traced to the outer shelf. It truncates underlying reflectors and represents an erosional surface formed during a low stand of sea level in the middle to late Pleistocene (Dinter, 1985; Smith, 1985b, oral commun., 1986; Wolf and others, 1985, 1986). Contour lines drawn on surface 3 suggest a broad, low-relief flood plain with two embayments that formed during the lower sea level preceding the Wainwrightian transgression. The embayments probably mark the ancestral Canning River (near borehole HLA 17) and Sagavanirktok River (near borehole HLA 12) drainages (Wolf and others, 1985, figs. 15 and 16). Marine sediments assigned to the Leffingwell Lagoon unit and the Wainwrightian transgression are generally conformable with surface 3 and dip gently northeast. In the boreholes, R3 coincides with the lithologic change from gravel and sand to silt and clay. Although R3 is assumed to define an erosional surface, beach and nearshore sands assigned to the Leffingwell Lagoon unit lie stratigraphically below R3 in HLA 8, 12,16, and 18. Gravels and sands interpreted as fluvial deposits and assigned to the Duchess sand unit in boreholes HLA 19 and 20 may be part of the overlying Leffingwell Lagoon unit. Although the bulk of sediments in the Leffingwell Lagoon unit are silt and clay, sandier sediments reappear in the upper part of the Leffingwell Lagoon unit just below the seismic reflector R4.

Eight samples were submitted for amino acid racemization from the Leffingwell Lagoon unit: three from HLA 19, two from HLA 18, and one each from HLA 16, HLA 17, and HLA 20. Except for sample 19-18, the alle/lle ratios range from 0.052 to 0.089 , with a mean value of 0.071 (aminozone 2 of Brigham, 1985a). Sample 19-18 includes numerous reworked specimens, thus the ratio is not considered reliable. On the basis of the postulated temperature history of the Arctic coastal plain (J.K. Brigham, oral commun., 1985; P.A. Smith, oral commun., 1985), the other seven ratios are interpreted as representing an interglacial stage older than the Sangamon (Pelukian transgression). The Leffingwell Lagoon unit is considered to be middle to late Pleistocene in age (Smith, 1985a, b), and in this paper it is correlated with the Wainwrightian transgression of Carter and others (1986). Future studies may find that this unit correlates in part with the early Pelukian transgression.

Overlying the Leffingwell Lagoon unit in all of the boreholes is a nonmarine to shallow marine or deltaic unit, the Maguire Islands unit or its lithologic equivalent (figs. 4-7). This unit is composed of laminated or thinly bedded silt with minor clayey or sandy silt, occasional seams of organic silt or peat, and a few scattered granules. In several boreholes a beach or lag deposit of sandy gravel occurs at the base of the unit. Sandier sediments are common above the beach deposits in the eastern part of the study area between the Canning River and the Shaviovik River, whereas clays and sandy clays are dominant in the remainder of the boreholes. Thickness of the unit ranges from $4.9 \mathrm{~m}$ (HLA 19) to 20.4 $m$ (HLA 17) in the offshore boreholes and from $3.7 \mathrm{~m}$ (HLA 11) to $14.2 \mathrm{~m}$ (HLA 14) in the nearshore boreholes. The Maguire Islands unit probably correlates with unnamed marine strata (Qp) in the western part of the study area (fig. 6).

Seismic reflector R4 (surface 4 of Wolf and others, 1985, 1986) is at or near the base of the Maguire Islands unit in each borehole where it is identified. Although R4 is not a strong reflector, and there is no evidence of a prolonged erosional event, it does truncate underlying reflectors, indicating that the Maguire Islands unit is not a continuation of the underlying unit. Contours on surface 4 indicate that it strikes westnorthwest, roughly parallel to the present coastline, and dips gently offshore (Wolf and others, 1985). The ancestral Canning River drainage was larger than today and was slightly west of the site of borehole HLA 17. A topographic high was north of what is now Flaxman Island. The numerous cut-andfill channels and steeply dipping strata that overlie surface 4 between boreholes 17 and 20 suggest that the Shaviovik and Canning Rivers were active during the Pelukian transgression. A series of discontinuous reflectors that slope gently seaward within the Maguire Islands unit suggests that the unit represents prodelta front and delta topset deposits. 
Seven amino acid analyses are available for the Maguire Islands unit (P.A. Smith, written commun., 1986). Two of these analyses are rejected because of the questionable results. The remaining five analyses had alle/Tle ratios ranging from 0.051 to 0.078 (aminozone 1 of Brigham, $1985 \mathrm{a}$ ), with a mean value of 0.065 . This value is slightly lower than the mean of 0.071 from the Leffingwell Lagoon unit, but it is close enough to suggest that the two units are probably not separated by a long time span. The Maguire Islands unit was probably deposited during the Pelukian transgression and is late Pleistocene in age. Icebonded sediments within this unit and the overlying unit rule out a Holocene age for the deposits.

Overlying the Maguire Islands unit in all of the eastern boreholes except HLA 14, 15, and 19 is a marine unit composed of pebbly silt to clay, informally named the Cross Island unit (figs. 4-7). The Cross Island unit is correlated with unnamed sediments (Qs) in the western part of the study area. Thickness of this unit ranges from $0.5 \mathrm{~m}$ (HLA 16) to $16.2 \mathrm{~m}$ (HLA 9). Pebble lithologies (dolomite, quartzite, red granite, and diabase) conform closely to those of the Flaxman Member of the Gubik Formation (Leffingwell, 1919; Dinter, 1985). Exposures of the Flaxman have been dated at 100,000 years B.P. by thermoluminescence (TL) dating (Carter and Galloway, 1985), which places this unit within the early Wisconsin, Simpsonian transgression. The Cross Island unit is, therefore, correlated with the Simpsonian transgression of late Pleistocene age. P.A. Smith (oral commun., 1985) recognized a seismic reflector (surface $\mathrm{R5}^{\prime}$ ) near the base of this unit in several boreholes (figs. 6,7 ). This reflector was not recognized by Wolf and others $(1985,1986)$ and is only recognized in a limited area. Sediment thickness and distribution suggest that during the lower sea level event following the Pelukian transgression and during the Simpsonian transgression, the ancestral Sagavanirktok River was active. The absence of the upper part of the Maguire Islands unit (Pelukian) in boreholes HLA 9, HLA 10, and HLA 11 suggests that the channel initially formed by the Sagavanirktok River was filled during the Simpsonian transgression with deltaic sediments of the Cross Island unit. Boreholes HLA 10 and 9 appear to be the primary sites of deltaic sedimentation.

The Mikkelsen Bay unit was identified in boreholes HLA 11 and HLA 19 (figs. 6, 7). In HLA 11, the unit is $2.9 \mathrm{~m}$ thick and composed of a soft silty sand with platy dolomite gravel in the upper meter. In HLA 19, it is 11 m thick and composed of a basal gravel lag with some dolomite pebbles, sand, and silty sand. This unit appears to represent channel deposits probably formed during the middle Wisconsin, as this unit overlies sediments of the Simpsonian transgression and underlies Holocene sediments.

The Stefansson Sound unit occurs in boreholes HLA 10, HLA 14, and HLA 15, where it is 2.8 to $6.7 \mathrm{~m}$ thick (fig. 6). Thinly laminated to mottled clayey silt, sandy silt, or silty sand, rich in organic detritus and black in color, is the pre- dominant sediment in the unit. Occasional gravel lenses and scattered shells and twigs may be present as well. The Stefansson Sound unit is probably equivalent to the unnamed deposits (Qf) in the western boreholes and correlative with the Flandrian marine unit identified in the Prudhoe Bay boreholes (McDougall and others, 1986). Surficial lag deposits in most boreholes may be partially correlative with the Stefansson Sound unit. Reflector R5, thought to represent the Holocene reflector of Wolf and others $(1985,1986)$, is present at the base of the unit in boreholes HLA 14 and 15.

\section{BIOSTRATIGRAPHY}

Biostratigraphic analysis of the PB boreholes in Prudhoe Bay identified four benthic foraminiferal assemblages that correlate with the Pelukian, Simpsonian, middle Wisconsin, and Flandrian transgressions (McDougall and others, 1986). Environmental conditions suggested by those benthic foraminiferal assemblages correspond to conditions suggested by analysis of the sediments and ostracode assemblages (McDougall and others, 1986). Pelukian foraminiferal faunas have moderate numbers of specimens and moderate diversities, and they include species which indicate that water conditions were deeper and warmer than those presently occurring at the site. Elphidiella groenlandica and Elphidium asklundi are common in the Pelukian, whereas Elphidium excavatum alba is rare. The moderate numbers of specimens and the low diversities of Simpsonian faunas indicate water conditions that were shallower and cooler than in the Pelukian but deeper and warmer than at present. Although specimen numbers and diversities are low, the middle Wisconsin faunas are similar to those of the Flandrian transgression (Holocene). Water conditions during the middle Wisconsin transgression were approximately the same as at present but slightly cooler and less saline; $\mathrm{El}$ phidium clavatum is a common component. Flandrian faunas have high foraminiferal numbers and moderate to low species diversities. Elphidium excavatum alba is common.

Elphidiella groenlandica, Elphidium asklundi, E. clavatum, and E. excavatum alba are the most useful species for biostratigraphic interpretation. Elphidiella groenlandica and Elphidium asklundi are common in sediments of the Pelukian and older transgressions. Rare to few specimens of these species occur in younger transgressions (Simpsonian to Flandrian); poor preservation of the tests suggests that the specimens are reworked. Elphidium excavatum al$b a$, which appears only rarely in the older transgressions, becomes abundant in the Flandrian transgression. Unfortunately, considerable reworking of older marine sediments and faunas obscures first or last appearances of many species. Foraminiferal interpretations of age, stratigraphic position, and marine transgressions must, therefore, rely heavily on paleoecologic analysis of the benthic foraminiferal assemblages and be carefully integrated with the interpretations based on sediments and other fossil groups. 


\section{PALEOECOLOGY}

Because most Pliocene and Pleistocene benthic foraminiferal species are living today, Holocene foraminiferal biofacies can be used to interpret the paleoenvironment. Foraminiferal biofacies, which are related to the environment, suggest physiochemical conditions such as water depth, temperature, and salinity. The abundance and occurrence of selected species refine the paleoecological interpretations further by suggesting conditions such as downslope transport or the presence of ice. The foraminiferal biofacies used to interpret the borehole faunas are derived from studies of Holocene benthic foraminifers in the Arctic.

Ecologic studies of Holocene Arctic benthic foraminifers (Vilks, 1969; Vilks and others, 1979; Knebel and others, 1974; Lagoe, 1979, 1980) were integrated with data from the Beaufort Sea (R.J. Echols, written commun., 1976; McDougall, unpub. data, 1991) to produce a sequence of benthic foraminiferal biofacies related to depth and physiochemical properties of seawater. Physiochemical properties include (1) organic matter, (2) sediment grain size, (3) ice gouging, and (4) water-mass characteristics including salinity and temperature (Coachman and Aagaard, 1974). These properties can be related to specific depths on the Beaufort Sea shelf and slope and to faunal changes. The resulting foraminiferal biofacies include a shallow and a deep inner neritic biofacies $(0-10 \mathrm{~m}$ and $10-20 \mathrm{~m}$ ), a middle neritic biofacies $(15-40 \mathrm{~m})$, an outer neritic biofacies $( \pm 35-200 \mathrm{~m})$, and an upper bathyal biofacies (200-1,500 m) (table 1). Depth, physiochemical properties, and faunas characteristic of these modern biofacies are summarized here.

Inner neritic biofacies faunas are generally found at depths of 0 to $20 \mathrm{~m}$ and within the Arctic Surface Water mass (temperature -1 to $-2^{\circ} \mathrm{C}$; salinity 27 to 34.5 per mil). The shallow inner neritic biofacies $(0-10 \mathrm{~m})$ is dominated by elphidiums, especially $E$. orbiculare, $E$. clavatum, and $E$. excavatum alba. These faunas are associated with lowsalinity waters, highly variable temperatures, and abundant suspended organic matter. The deep inner neritic biofacies $(10-20 \mathrm{~m})$ is controlled by slightly higher salinities, more equitable temperatures, and a slight reduction in the quantity of suspended organic matter. In the deep inner neritic biofacies, Buccella frigida constitutes at least 5 percent of the fauna, and elphidiums occur in reduced numbers. A narrow band of slightly higher abundances of miliolids (Gordiospira, Quinqueloculina, Scutuloris, and Triloculi$n a)$ occurs near the deeper limit of this biofacies.

The middle neritic biofacies, generally found at depths of $15-40 \mathrm{~m}$, is recognized by the dominance of cassidulinids (Cassidulina islandica and C. norcrossi). Elphidium bartletti is more common in this biofacies, whereas other elphidiums are reduced in number. Although influenced by the Arctic Surface Water mass (temperature -1 to $-2^{\circ} \mathrm{C}$; salinity 27 to 34.5 per mil), faunas in the middle neritic

Table 1. Species diagnostic of modern benthic foraminiferal biofacies, Beaufort Sea shelf, Alaska.

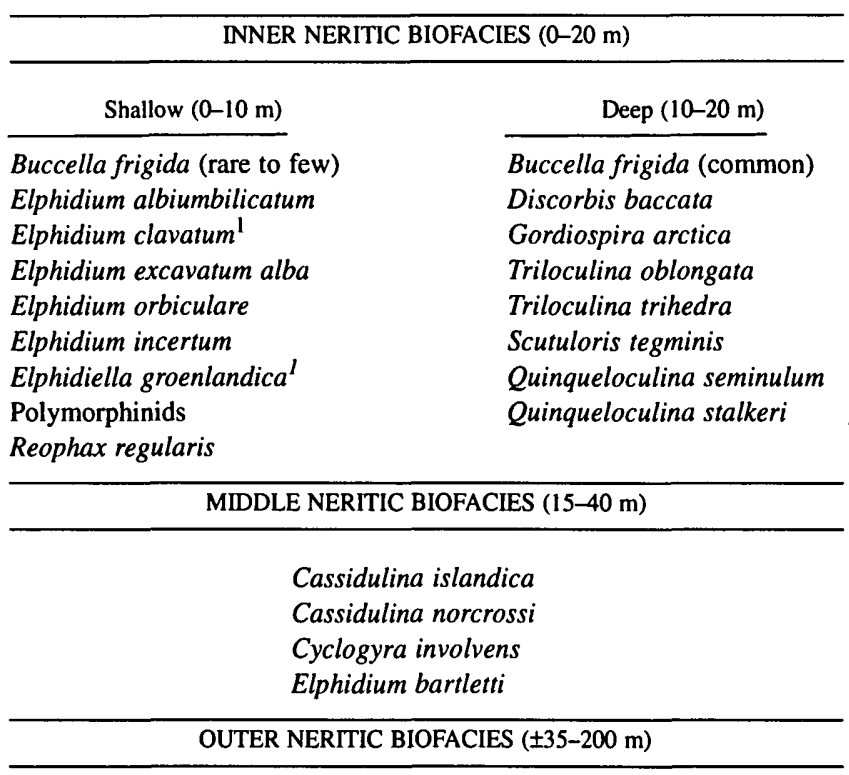

Alveolophragmium crassimargo

Alveolophragmium jeffreysii

Ammodiscus minutissimus

Astrononion gallowayi

Cibicides lobatulus

Eggerella advena

Melonis zaandamae

Psammosphaera fusca

Pyrgo williamsoni

UPPER BATHYAL BIOFACIES $(200-1,500 \mathrm{~m})$
Bolivina pacifica

Cassidulina crassa

Cassidulina teretis

Epistominella arctica

Nonionella auricula

Nonionella digitata
Quinqueloculina agglutinata Recurvoides turbinatus

Reophax arctica

Reophax curtus

Spiroplectammina biformis

Stainforthia complanata

Stainforthia concava

Textularia torquata

Trochammina nana

\footnotetext{
${ }^{1}$ Reworked? in Beaufort Sea assemblages
}

biofacies respond to an increase in sediment grain size and intensification of ice gouging.

The outer neritic biofacies $( \pm 35-200 \mathrm{~m})$ is associated with the outer limit of ice gouging $(37-41 \mathrm{~m})$ and with the distribution of a subsurface Arctic Surface Water mass in which salinity increases gradually between 30 and $300 \mathrm{~m}$ and temperature decreases between 50 and $200 \mathrm{~m}$ (Coachman and Aagaard, 1974). Diagnostic outer neritic faunas include rare calcareous forms such as Stainforthia concava, Astrononion gallowayi, and Melonis zaandamae as well as in situ and transported species with upper depth limits in shallower water. Arenaceous faunas characteristic of the warmer Bering Sea Water are found at about $50 \mathrm{~m}$. This fauna includes the species Eggerella advena, Reophax arctica, Spiroplectammina biformis, and Textularia torquata. 
The upper bathyal biofacies $(200-1,500 \mathrm{~m})$ contains common calcareous and arenaceous species (table 1). The faunal distribution is controlled primarily by the presence of the warm Atlantic Water mass and associated warmer temperatures $\left(-1\right.$ to $0.5^{\circ} \mathrm{C}$ ) and higher salinities (approximately 34.5 per mil).

\section{BOREHOLE HLA 3 (Mf5720)}

Borehole HLA 3, the westernmost borehole, was drilled $4.8 \mathrm{~km}$ north of Long Island (Jones Islands chain, fig. 1). The sediment recovered at this site consists of $23.3 \mathrm{~m}$ of gravel and pebbly sand overlain by $6.0 \mathrm{~m}$ of marine sand, gravel, silty clay, and sandy silt (fig. 8). The lower gravels and pebbly sands (below $6.0 \mathrm{~m}$ ) are interpreted as undifferentiated Pleistocene outwash, and the overlying marine sediments represent two transgressions. The older transgression is represented by $1.2 \mathrm{~m}$ of gravel, $1.2 \mathrm{~m}$ of sand and gravelly sand, and $2.0 \mathrm{~m}$ of silty clay and sandy silt. Sediments of the younger transgression include $0.6 \mathrm{~m}$ of gravelly sand and $1.0 \mathrm{~m}$ of clayey gravelly silt. These marine sediments were deposited during the Simpsonian and Flandrian transgressions (P.A. Smith, oral commun., 1985). Depths of stratigraphic units in the borehole follow.

HLA 3

\begin{tabular}{llr}
\hline \multirow{2}{*}{ Stratigraphic unit } & \multicolumn{2}{c}{$\begin{array}{c}\text { Depth, in meters } \\
\text { below mudline }\end{array}$} \\
\cline { 2 - 3 } & Top & \multicolumn{1}{c}{ Bottom } \\
\hline Qf (Flandrian transgression) ........................ & 0.0 & 1.6 \\
Qs (Simpsonian transgression) ..................... & 1.6 & 6.0 \\
Undifferentiated Pleistocene outwash .......... & 6.0 & 29.3 \\
\hline
\end{tabular}

Benthic foraminifers from the older transgression occur in three samples in the marine portion of HLA 3 (fig. 9, table 2). Samples 3-3 and 3-2 represent the Simpsonian transgression. Sample 3-1, which is $0.1 \mathrm{~m}$ below the Flandrian (Holocene) beach gravels, has a reworked or mixed fauna containing specimens from the Simpsonian and older transgressions.

The Simpsonian faunas in samples 3-3 and 3-2, are characterized by common to abundant, low-diversity foraminiferal faunas. The oldest sample, $3-3$, is dominated by Elphidium orbiculare (53\%) and E. incertum (43\%). Similar dominances are observed in sample 3-2, where $E$. orbiculare (12.3\%), E. incertum (4.6\%) and Elphidium spp. (juveniles of $E$. orbiculare and $E$. incertum, $81.8 \%$ ) form the bulk of the assemblage. This association indicates deposition in the shallow inner neritic biofacies (less than $10 \mathrm{~m}$ ) and cold, low-salinity water.

The benthic foraminiferal fauna in sample 3-1 contains common and moderately diverse benthic foraminifers. This fauna is dominated by elphidiums and thus indicates shallow, inner neritic water biofacies $(0-10 \mathrm{~m})$ and low salinities.
Poorly preserved specimens of Elphidiella groenlandica dominate sample 3-1 (30\%). This species is usually common in Pelukian or older beach and nearshore deposits; its presence in sample 3-1 suggests reworking of older marine inner neritic deposits. Rare middle neritic (Cassidulina norcrossi) and bathyal species (Nonionella sp.) in sample 3-1 have

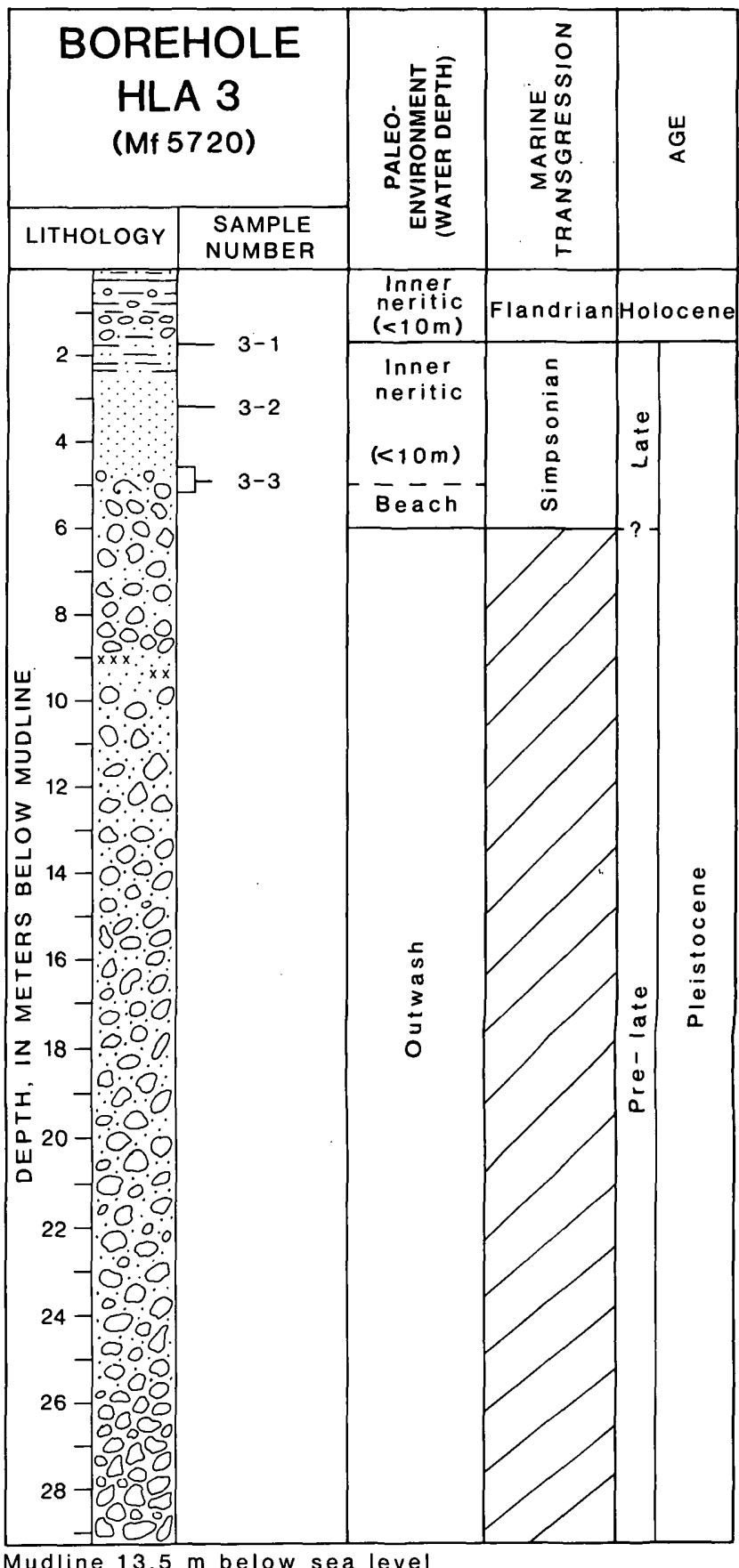

Figure 8. Lithology, sample locations, paleoenvironments, and ages of borehole HLA 3, Beaufort Sea shelf, Alaska. Paleoenvironment contact dashed where approximate. Lithostratigraphic units and transgressions summarized in figures 4 and 5 and in figures 2 and 3 , respectively. 


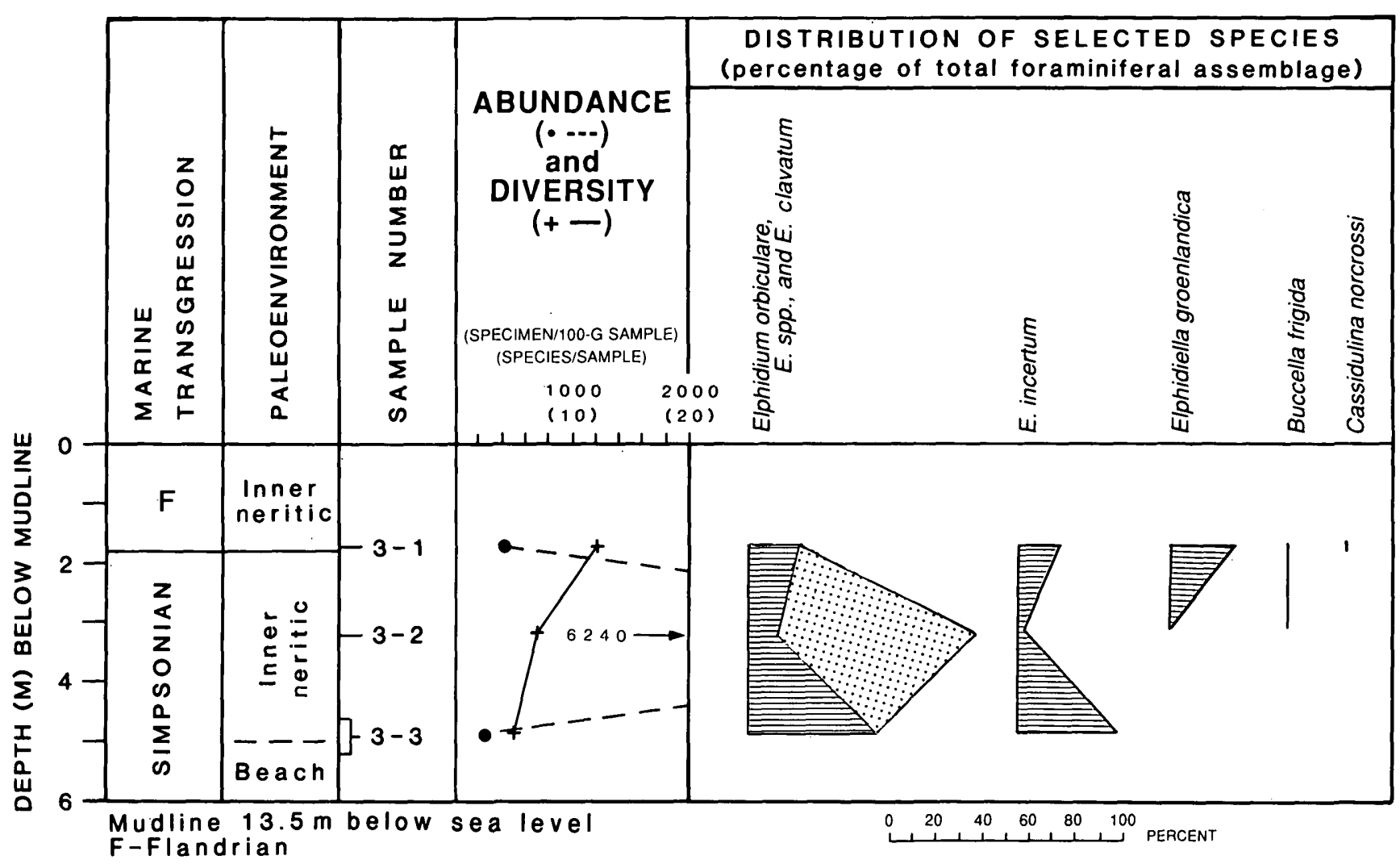

Figure 9. Benthic foraminiferal abundance (dot or number) and diversity (cross) and distribution of selective species in borehole HLA 3, Beaufort Sea shelf, Alaska. See table 2 for foraminiferal values. Paleoenvironment contact dashed where approximate. Transgressions summarized in figures 2 and 3.

moderately well preserved to poorly preserved teșts and suggest that older deep marine sediments are also being reworked. Many of these elphidiums have worn or broken tests that may result from in situ reworking of the tests or the reworking of older inner neritic species.

\section{BOREHOLE HLA 4 (Mf5721)}

Borehole HLA 4 was drilled north of Reindeer Island in the western part of the study area (fig. 1). Borehole HLA 4 penetrated $30.9 \mathrm{~m}$ of sediment (fig. 10). The basal 12.6 $m$ of sediment grades from gravel to sandy gravel and pebbly sand and is interpreted as Pleistocene outwash. This is overlain by three marine units that are interpreted as representing the Pelukian, Simpsonian, and Flandrian transgressions (P.A. Smith, oral commun., 1985). The Pelukian is represented by gravels that grade upward to a fine silty pebbly sand and pebbly silt and by marine silt and silty clay. Overlying these sediments is a layer of oxidized silt that is interpreted as a paleosol. Sediments of the Simpsonian transgression include a basal muddy gravel (0.6 m thick) and stiff silty clay with coarse sand grains and organic silt ( $2.0 \mathrm{~m}$ thick). The youngest transgression, the Flandrian, is represented by $1.0 \mathrm{~m}$ of gravel and peb- bly sand, $1.8 \mathrm{~m}$ of stiff clay, and $2.4 \mathrm{~m}$ of fine sand and silty sand that contains shells, twigs, and lumps of redeposited overconsolidated clay. The upper meter of sand in HLA 4 may be a lag deposit. Depths of stratigraphic units in the borehole follow.

HLA 4

\begin{tabular}{|c|c|c|}
\hline \multirow[t]{2}{*}{ Stratigraphic unit } & \multicolumn{2}{|c|}{$\begin{array}{l}\text { Depth, in meters } \\
\text { below mudline }\end{array}$} \\
\hline & Top & Bottom \\
\hline Qf (Flandrian transgression) ............................ & 0.0 & 5.2 \\
\hline 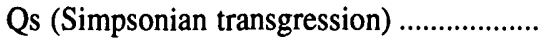 & 5.2 & 7.6 \\
\hline 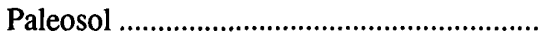 & 7.6 & 7.8 \\
\hline 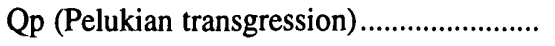 & 7.8 & 18.3 \\
\hline Undifferentiated Pleistocene outwash......... & 18.3 & 30.9 \\
\hline
\end{tabular}

Sixteen samples from borehole HLA 4 contain benthic foraminifers that are diagnostic of late Pleistocene and Holocene deposition (fig. 11, table 3). Two additional samples, 4-10A and 4-10B were not examined for foraminifers and ostracodes. The transgressions recognized in borehole HLA 4 are Pelukian, Simpsonian, and Flandrian.

The Pelukian faunas in samples 4-16 to 4-11 are characterized by abundant and moderately diverse (average 15) 
foraminiferal assemblages. Samples taken just above the beach gravels and sands contain moderate abundances of Elphidium orbiculare, E. clavatum, and E. incertum, and common to rare specimens of Cassidulina islandica, $C$.

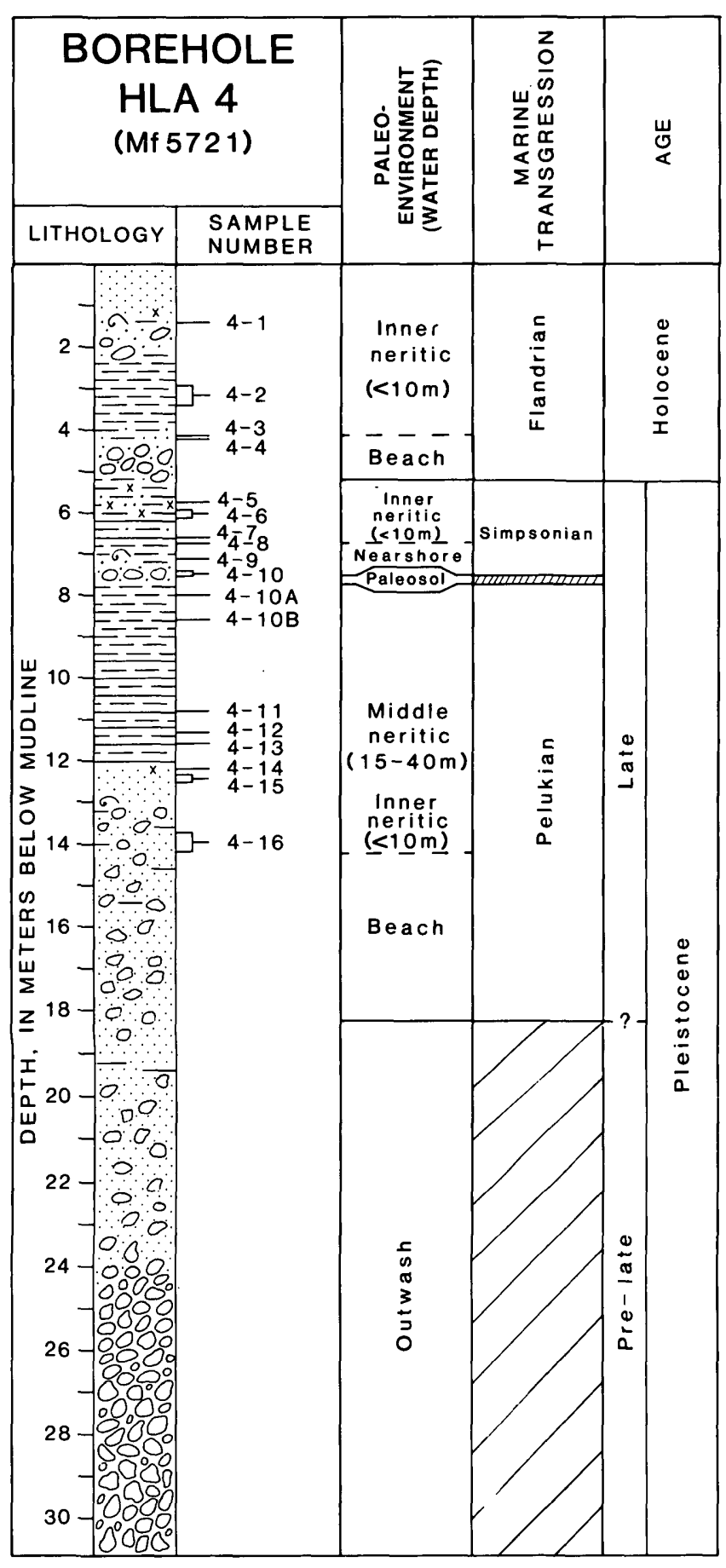

Mudline $8.5 \mathrm{~m}$ below sea level

Figure 10. Lithology, sample locations, paleoenvironments, and ages of borehole HLA 4, Beaufort Sea shelf, Alaska. Paleoenvironment contacts dashed where approximate. Lithostratigraphic units and transgressions summarized in figures 4 and 5 and in figures 2 and 3 , respectively. norcrossi, and Buccella frigida. The elphidiums indicate cool, shallow water. Cassidulinids and Buccella increase in abundance upsection, indicating an increase in water depths from shallow inner neritic (0-10 m, sample 4-16) to middle neritic (15-40 m, samples 4-15 to 4-11). Rare occurrences of Stainforthia concava, Triloculina trihedra, and various species of Fissurina and Lagena suggest that water depths approach outer neritic depths ( $\pm 35-200 \mathrm{~m})$ during the middle of the Pelukian interval (sample 4-11).

Simpsonian samples, 4-10 to 4-5 overlie a paleosol. Foraminifers in this interval are abundant, diversities are moderate (average 13 species), and elphidiums dominate. The abundance of Buccella frigida increases slightly in this interval, representing 3 to 12 percent of the assemblage. Cassidulinids and other middle and outer neritic species are few or absent. Elphidiella groenlandica is present but rare in most of these samples, suggesting that temperatures were warmer than at present. These associations indicate that deposition occurred in the deep inner neritic biofacies $(10-20 \mathrm{~m})$ and that water temperatures were approximately the same as or slightly warmer than at present and salinity was low.

The uppermost group of samples, 4-4 to 4-1, is separated from the underlying groups by a beach deposit at 5.2 to 4.2 $\mathrm{m}$ in the borehole. The fauna in these upper samples indicates a Holocene age and shallow inner neritic deposition. Foraminifers are abundant and moderately diverse (average 15 species). Elphidium clavatum dominates the lower two samples $( \pm 50 \%)$, whereas $E$. orbiculare dominates the upper two samples (average 43\%). Other species also have slight changes in abundances between the upper and lower samples, but they are not as great as in the elphidiums. The presence of Buccella frigida (5-7\%) and cassidulinids indicate the deeper inner neritic biofacies having water depths of 10 to $20 \mathrm{~m}$ and more normal marine salinities.

\section{BOREHOLE HLA 5 (Mf5722)}

Borehole HLA 5 was drilled in the western part of the study area, $7.2 \mathrm{~km}$ north of Stump Island, between HLA 3 and HLA 4 (fig. 1). This borehole penetrated $91.4 \mathrm{~m}$ of sediment that is interpreted as outwash, thaw lake, beach, and marine deposits (P.A. Smith, oral commun., 1985; fig. 12). Sediments identified as outwash were found from the base of the hole $(91.4 \mathrm{~m})$ to $74.4 \mathrm{~m}$, from 65.8 to $21.0 \mathrm{~m}$, and from 15.9 to $8.5 \mathrm{~m}$; they are characterized by pebbly sand and sandy gravel. Thaw-lake deposits between the two oldest outwash sequences are characterized by clayey silt with seams of fine sand and laminae of detrital peat and may correlate with the Fishcreekian Staines River unit. The marine sediments found from 21.0 to $15.9 \mathrm{~m}$ and from $8.5 \mathrm{~m}$ to the mudline are interpreted as representing the Wainwrightian, Pelukian, Simpsonian, and Flandrian transgressions. The oldest marine sediments, tentatively 
identified as Wainwrightian, consist of $0.4 \mathrm{~m}$ of sand with shell fragments overlain by $4.7 \mathrm{~m}$ of silty sand. Pelukian sediments consist of $0.3 \mathrm{~m}$ of gravelly sand overlain by $2.1 \mathrm{~m}$ of silty sand with occasional shell fragments. Simp- sonian sediments are $5.8 \mathrm{~m}$ thick and grade from sand with wood and shells at the base to sandy silt to black silt at the top. These sediments are overlain by $0.3 \mathrm{~m}$ of fine sand that is interpreted as a Holocene lag deposit (P.A.

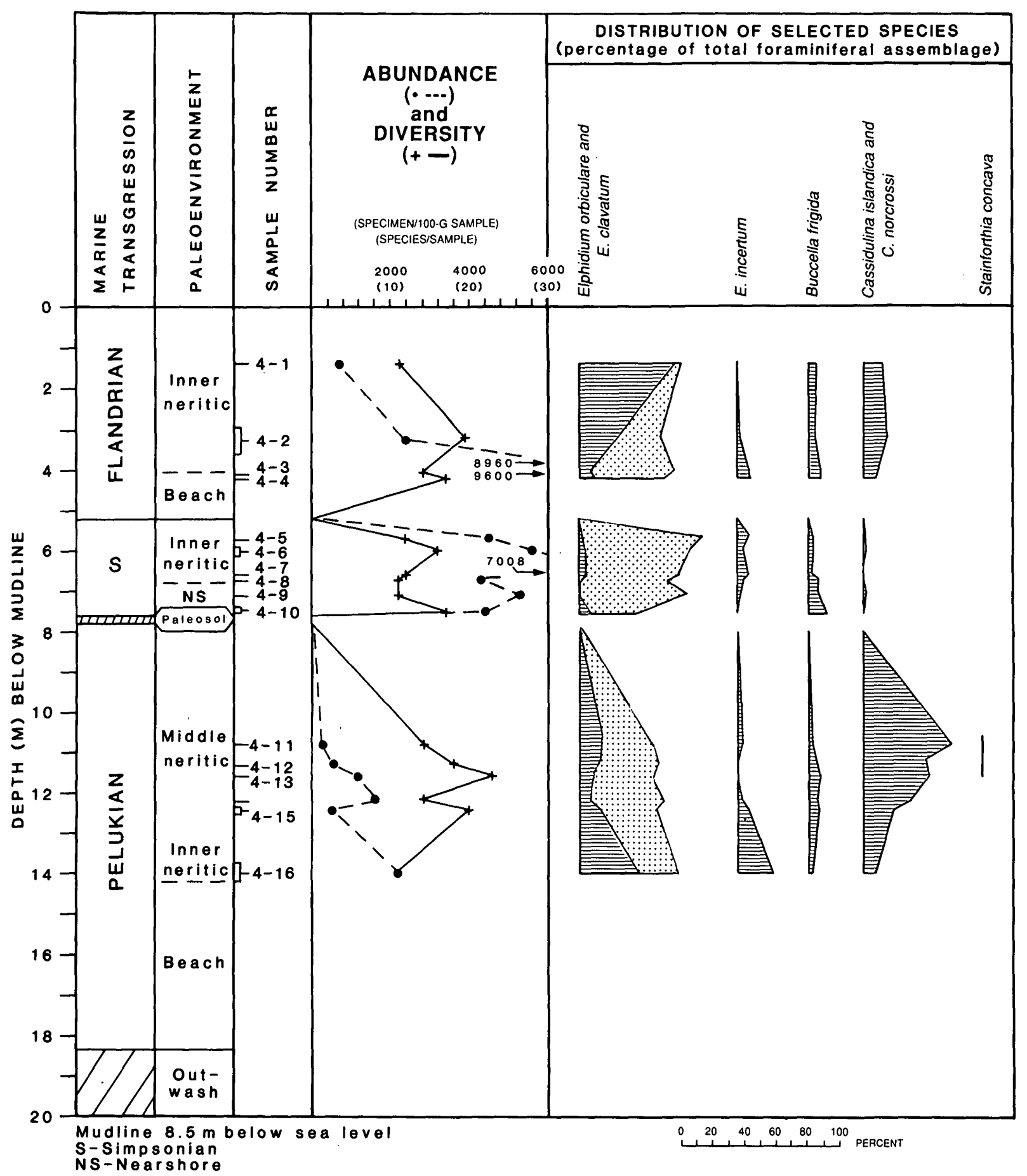

Figure 11. Benthic foraminiferal abundance (dot or number) and diversity (cross) and distribution of selective species in borehole HLA 4, Beaufort Sea shelf, Alaska. See table 3 for foraminiferal values. Paleoenvironment contacts dashed where approximate. Transgressions summarized in figures 2 and 3. 


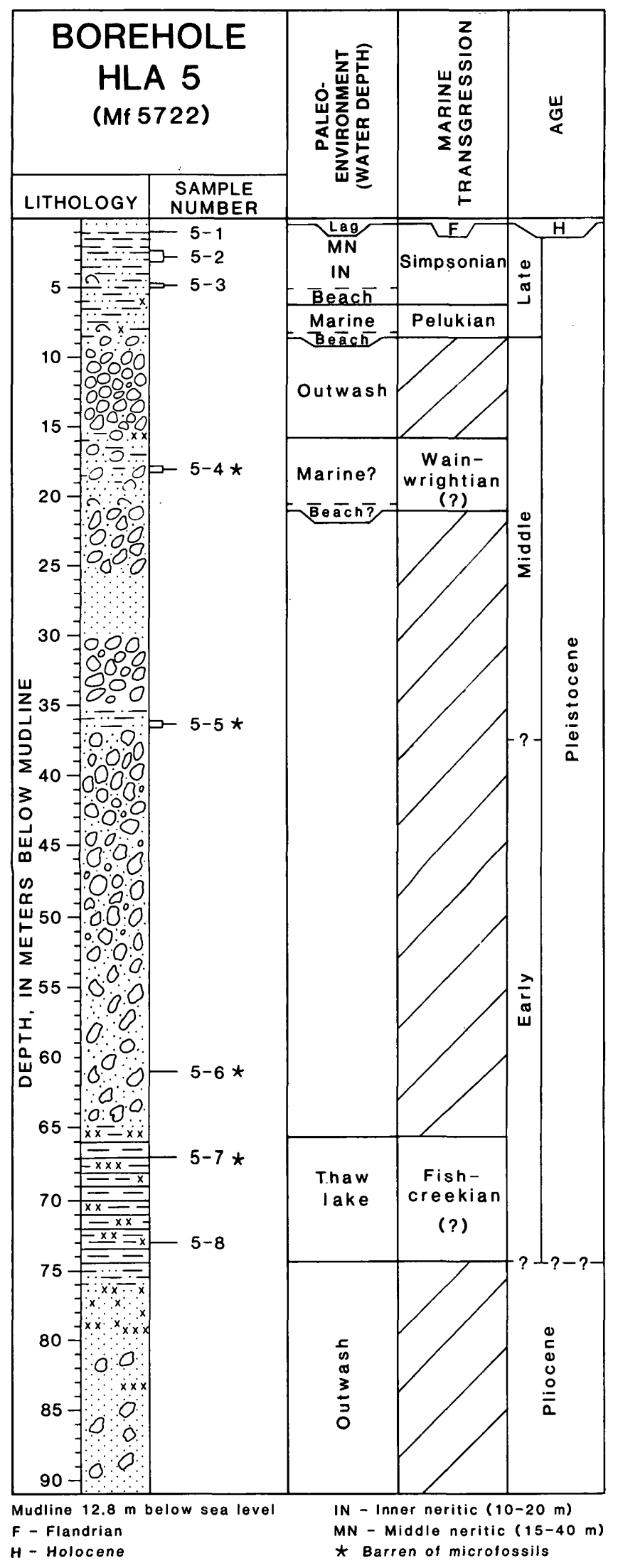

Figure 12. Lithology, sample locations, paleoenvironments, and ages of borehole HLA 5, Beaufort Sea shelf, Alaska. Paleoenvironment contacts dashed where approximate. Lithostratigraphic units and transgressions summarized in figures 4 and 5 and in figures 2 and 3 , respectively.
Smith, oral commun., 1985). Depths of stratigraphic units in the borehole follow.

HLA 5

\begin{tabular}{|c|c|c|}
\hline \multirow{2}{*}{ Stratigraphic unit } & \multicolumn{2}{|c|}{$\begin{array}{l}\text { Depth, in meters } \\
\text { below mudline }\end{array}$} \\
\hline & Top & Bottom \\
\hline 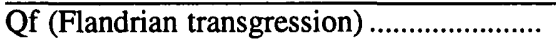 & 0.0 & 0.3 \\
\hline 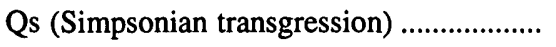 & .3 & 6.1 \\
\hline 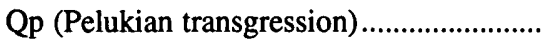 & 6.1 & 8.5 \\
\hline Undifferentiated Pleistocene outwash......... & 8.5 & 15.9 \\
\hline Qw? (Wainwrightian transgression?).......... & 15.9 & 21.0 \\
\hline Undifferentiated Pleistocene outwash......... & 21.0 & 65.8 \\
\hline 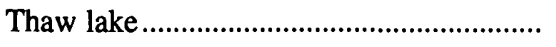 & 65.8 & 74.4 \\
\hline Undifferentiated Pleistocene outwash......... & 74.4 & 91.4 \\
\hline
\end{tabular}

Eight samples were submitted for microfossil analysis. A single juvenile ostracode was found in sample 5-8. Samples 5-7 to 5-4 are barren of microfossils. Samples 5-3 to 5-1 contain benthic foraminifers (fig. 13, table 4) that represent the late Pleistocene Simpsonian transgression.

The ostracode species Sarsicytheridea bradii in sample 5-8 is a common long-ranging eurytopic species, capable of living in estuarine and normal marine environments (E.M. Brouwers, written commun., 1985). Sediments in sample 5-8 are, however, interpreted by P.A. Smith (written commun., 1986) as thaw-lake deposits. This interpretation is supported by lithology, abundant plant debris, and lack of benthic foraminifers and other marine organisms. The single specimen of $S$. bradii found in this sample may be reworked or transported rather than representative of in situ deposition.

Faunas from samples 5-3 to 5-1 represent the Simpsonian transgression. Foraminiferal number and diversity are low to moderate and increase upsection. Increasing temperatures are suggested by changes in dominance patterns of benthic foraminiferal species: Elphidium incertum dominates sample 5-3, and E. clavatum dominates the upper two samples. The shift in dominance may reflect a change from cold waters associated with ice to warmer waters without ice. Increasing water depths are also indicated by the foraminiferal assemblages. The common occurrence of Cassidulina islandica and $C$. norcrossi (average 25\%) in the upper samples suggests that deposition occurred in the middle neritic biofacies, where water depths range from 15 to 40 meters.

\section{BOREHOLE HLA 6 (Mf5723)}

Borehole HLA 6 was drilled northeast of Reindeer Island between Argo and Cross Islands, in the western part of the study area (fig. 1). This borehole penetrated $31.2 \mathrm{~m}$ of sediment consisting of $9.4 \mathrm{~m}$ of sandy gravel interpreted as glacial outwash and $21.8 \mathrm{~m}$ of marine deposits (P.A. Smith, oral commun., 1985; fig. 14) that represent three transgressions: Wainwrightian, Pelukian, and Flandrian. Sediments 


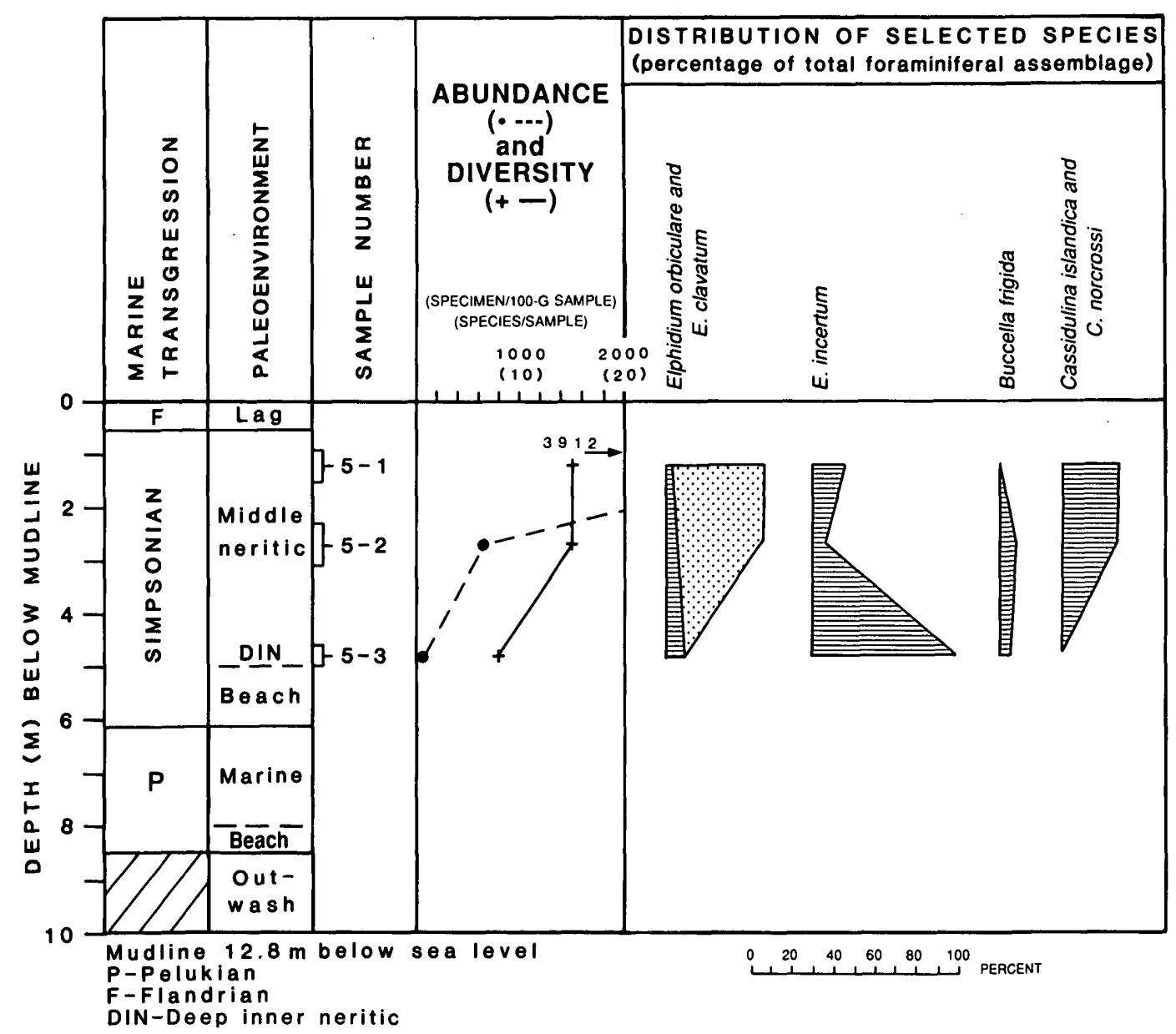

Figure 13. Benthic foraminiferal abundance (dot or number) and diversity (cross) and distribution of selective species in borehole HLA 5, Beaufort Sea shelf, Alaska. See table 4 for foraminiferal values. Paleoenvironment contacts dashed where approximate. Transgressions summarized in figures 2 and 3.

assigned to the Wainwrightian transgression consist of a 3.1-m-thick beach deposit of sandy gravel and gravelly sand, a 1.8-m-thick section of silty fine sand with abundant twigs and wood chips, and $4.7 \mathrm{~m}$ of silty sand and sandy silt with some detrital plant debris and a few pebbles. The Wainwrightian sediments are overlain by a fine sand that is interpreted as a paleosol. The Pelukian sediments consist of silt, silty clay, and clay. Most of the Flandrian sediments consist of stiff sandy silt with some organic debris; the upper $0.3 \mathrm{~m}$ is a fine sand interpreted as a Holocene lag deposit. Depths of stratigraphic units in the borehole follow.

HLA 6

\begin{tabular}{|c|c|c|}
\hline \multirow{2}{*}{ Stratigraphic unit } & \multicolumn{2}{|c|}{$\begin{array}{l}\text { Depth, in meters } \\
\text { below mudline }\end{array}$} \\
\hline & Top & Bottom \\
\hline 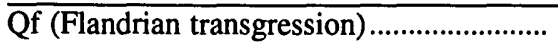 & 0.0 & 2.0 \\
\hline 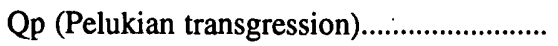 & 2.0 & 12.0 \\
\hline 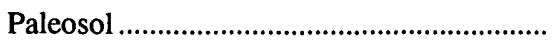 & 12.0 & 12.2 \\
\hline Qw (Wainwrightian transgression ................... & 12.2 & 21.8 \\
\hline Undifferentiated Pleistocene outwash ......... & 21.8 & 31.2 \\
\hline
\end{tabular}

Nine samples were analyzed for microfossils between 17.5 and $1.1 \mathrm{~m}$ in borehole HLA 6. Benthic foraminifers are present in all samples (fig. 15, table 5) except 6-8, which contains only ostracodes. Three marine transgressions are recognized in the borehole: Wainwrightian, Pelukian, and Flandrian.

The fauna in sample 6-9 contains few benthic foraminifers ( 33 specimens) and rare ostracodes ( 8 specimens); the fauna in sample 6-8 is composed entirely of ostracodes (245 specimens). The foraminiferal assemblage in sample 6-9 is dominated by species that prefer cold, low-salinity waters and commonly characterize the initial phases of a transgression. The dominance of Elphidium incertum (49\%) indicates the presence of ice; E. clavatum (27\%) and $E$. orbiculare (18\%) indicate shallow, low-salinity water. The single specimen of Cassidulina norcrossi was probably reworked from an older transgression. The ostracode specimens in sample 6-9 are entirely nonmarine, whereas the abundant ostracode specimens in sample 6-8 include five nonmarine species and a single estuarine to shallow-marine species, Paracyprideis pseudopunctillata (1.6\% of the fauna; E.M. Brouwers, written commun., 
1985). The ostracode assemblages suggest this interval is nonmarine. The presence of foraminiferal specimens suggests either that foraminifers are reworked (or transported) into a nonmarine environment or that nonmarine ostra-

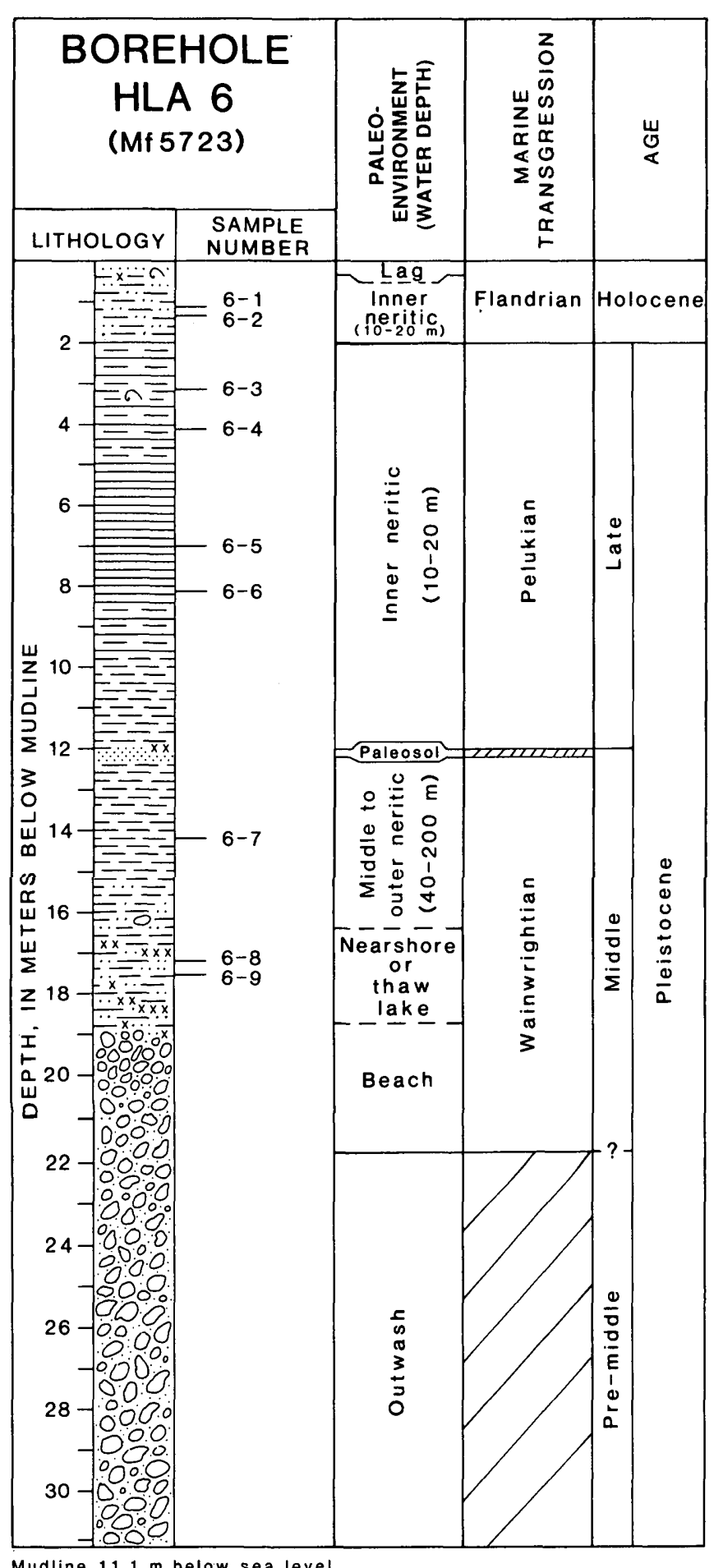

Mudline $11.1 \mathrm{~m}$ below sea level

Figure 14. Lithology, sample locations, paleoenvironments, and ages of borehole HLA 6, Beaufort Sea shelf, Alaska. Paleoenvironment contacts dashed where approximate. Lithostratigraphic units and transgressions summarized in figures 4 and 5 and in figures 2 and 3 , respectively. codes are reworked (or transported) into a marine environment. The preservation of thin-shelled ostracode specimens favors the first alternative (E.M. Brouwers, written commun., 1985), whereas the abundance of foraminiferal specimens characteristic of cold, low-salinity water and the presence of identifiable reworked foraminiferal specimens (Cassidulina norcrossi) support the latter alternative. Deposition of samples 6-9 and 6-8 probably occurred during the Wainwrightian transgression at a time of lower but rising sea levels.

Sample 6-7 contains abundant and diverse foraminifers that represents the Wainwrightian transgression. Although inner neritic species of Elphidium are common, Cassidulina islandica and C. norcrossi (20\%) and associated Buccella frigida (4\%) indicate that deposition occurred in a middle neritic biofacies $(15-40 \mathrm{~m})$. The presence of outer neritic species (Cassidulina crassa, Epistominella arctica, E. vitrea, and Stainforthia concava) indicates that water depths may have been greater or that water temperatures were warmer, as most of these species are today associated with the warmer Atlantic water mass on the upper slope of the Beaufort Sea.

Samples 6-6 to 6-3 from the Pelukian transgression contain abundant benthic foraminifers and are stratigraphically above the paleosol identified at $12 \mathrm{~m}$. Benthic foraminifers from sample 6-6 suggest that deposition occurred in the deeper inner neritic biofacies $(10-20 \mathrm{~m})$. Because the abundance of Buccella frigida decreases from 7 percent in sample 6-6 to less than 5 percent in the three overlying samples, and because the elphidiums become slightly more diverse and abundant in the upper samples, water depths may have shallowed upsection. An increase in downslope transport may also account for these changes and is the preferred interpretation. In sample 6-3, abundant Elphidium albiumbilicatum makes up 16 percent of the fauna. Abundant occurrences of this species have been previously attributed to the influx of low salinity water and downslope transport (Knudsen, 1978; Guilbault, 1980). The foraminifers indicate that deposition occurred in the deep inner neritic biofacies $(10-20 \mathrm{~m})$ and that the amount of transported material varied from abundant to rare. The presence of Cassidulina islandica in samples 6-6 and 6-3 may be the result of in situ deposition or reworking from older marine sediments.

Abundant and diverse benthic foraminifers in samples 6-2 and 6-1, assigned to the Flandrian transgression, suggest that deposition occurred in the deeper inner neritic biofacies (10-20 m). Elphidium clavatum, E. orbiculare, and $E$. incertum dominate the foraminiferal assemblages. Buccella frigida averages 8 percent of the fauna, and few to common cassidulinids are present. These assemblages are typical of the deep inner neritic biofacies (10-20 m). The occurrence of Spiroplectammina biformis in sample 6-1 implies the presence of a slightly warmer water mass, probably with its origin in the Bering Sea. 
BOREHOLE HLA 7 (Mf5724)

Borehole HLA 7 was drilled approximately $15 \mathrm{~km}$ north of Prudhoe Bay midway between Heald Point and Cross
Island, and shoreward of the island chain that borders most of northern Alaska (fig. 1). Drilling at this site penetrated $30.5 \mathrm{~m}$ of sediment identified as outwash and marine sediments of the Pelukian, Simpsonian, and Flandrian

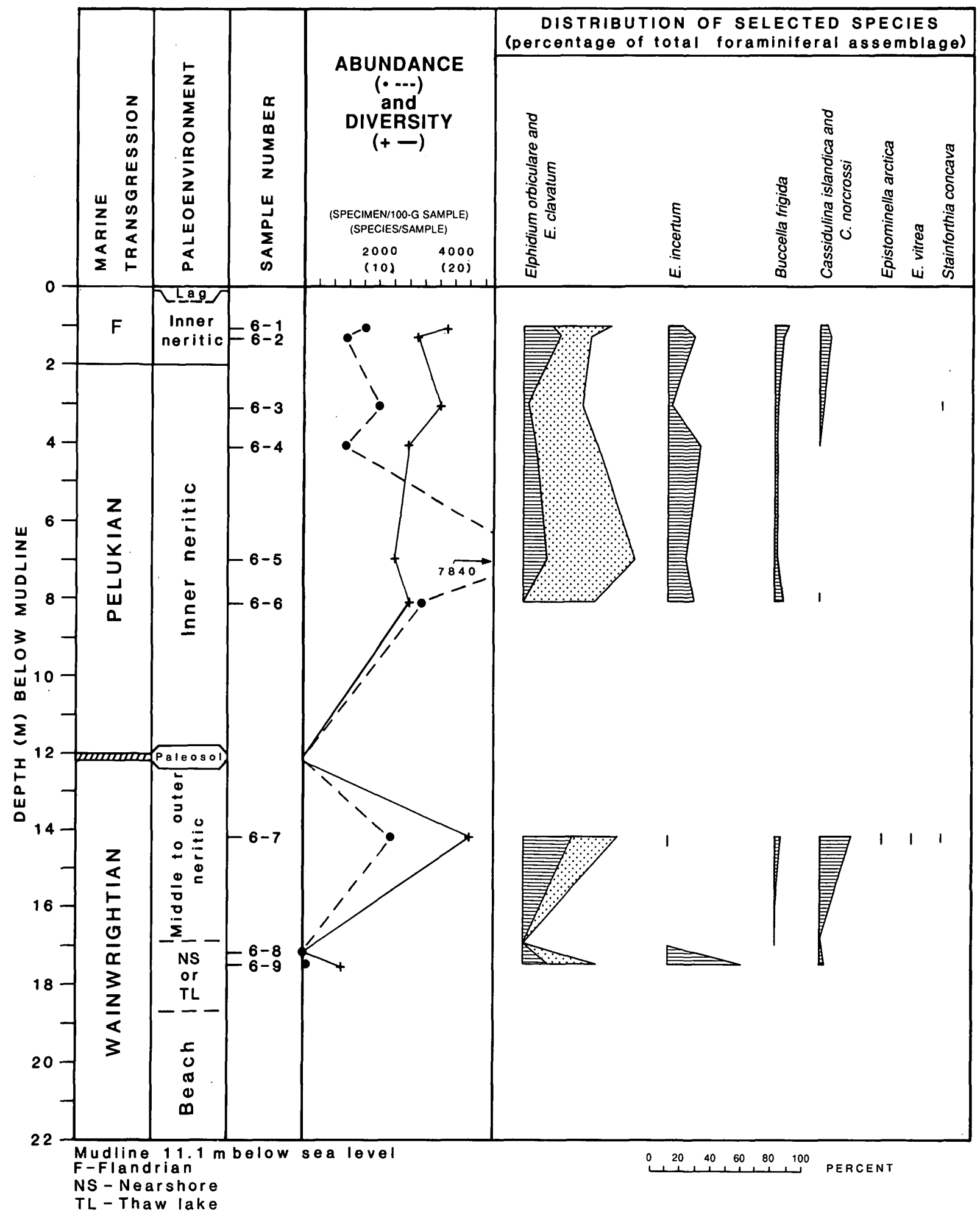

Figure 15. Benthic foraminiferal abundance (dot or number) and diversity (cross) and distribution of selective species in borehole HLA 6, Beaufort Sea shelf, Alaska. See table 5 for foraminiferal values. Paleoenvironment contacts dashed where approximate. Transgressions summarized in figures 2 and 3. 
transgressions (P.A. Smith, oral commun., 1985; fig. 16). Although sandy gravel occurs at the base $(30.5-29.6 \mathrm{~m})$ and sporadically between 25.5 and $20.2 \mathrm{~m}$, the outwash consists primarily of gravel. Pelukian sediments include a 1.3-m-thick beach and nearshore deposit of pebbly sand and sandy gravel and a 9.0-m unit of sediment that grades from pebbly silty sand with wood fragments to silty sand and stiff clayey silt with occasional organic debris. The Simpsonian sediments consist of a clayey silt with common shell fragments. Sediments assigned to the Flandrian transgression grade from a sandy silt at the base to a clay and clayey silt near the top that are overlain by $0.2 \mathrm{~m}$ of fine sand (Holocene lag deposit). Depths of stratigraphic units in the borehole follow.

HLA 7

\begin{tabular}{|c|c|c|}
\hline \multirow{2}{*}{ Stratigraphic unit } & \multicolumn{2}{|c|}{$\begin{array}{l}\text { Depth, in meters } \\
\text { below mudline }\end{array}$} \\
\hline & Top & Bottom \\
\hline Qf (Flandrian transgression) ............................. & 0.0 & 6.4 \\
\hline 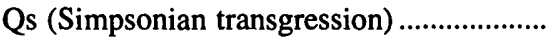 & 6.4 & 19.9 \\
\hline 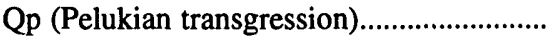 & 9.9 & 20.2 \\
\hline Undifferentiated Pleistocene outwash ......... & 20.2 & 30.5 \\
\hline
\end{tabular}

Benthic foraminifers are present in 13 of the 14 samples submitted for microfossil analysis from borehole HLA 7 (fig. 17, table 6). Faunas range in age from late Pleistocene to Holocene and represent parts of the Pelukian (samples 7-13 to 7-11), Simpsonian (samples 7-10 to 7-8) and Flandrian (samples 7-6 to 7-1) transgressions. Sample 7-7 contains a mixture of Flandrian and Simpsonian species. Sample 7-14 at $17.8 \mathrm{~m}$, taken approximately $1 \mathrm{~m}$ above sediments interpreted as Pelukian beach deposits, is barren of foraminifers and ostracodes.

Pelukian samples, 7-13 to 7-11, contain abundant and diverse benthic foraminifers. In samples 7-13 and 7-12, Cassidulina islandica and $C$. norcrossi compose more than 25 percent of the benthic foraminiferal assemblage, Buccella frigida averages 5 percent, and elphidiums are common, indicating that deposition occurred in the middle neritic biofacies (15-40 m). Rare occurrences of Stainforthia concava, Triloculina trihedra, and various species of Fissurina, Lagena, and Oolina suggest proximity of the outer shelf water mass (subsurface Arctic Surface Water mass).

The number of foraminiferal specimens (37,504 specimens per 100 grams) is anomalously high in sample 7-11. Diversity (14 species) is similar to that in the older samples, but the composition shifts to the distinctive shallow inner neritic $(0-10 \mathrm{~m})$ Elphidium-dominated assemblage. The abundance of $E$. incertum (15\%) suggests cold, low-salinity waters. The high number of foraminifers with little apparent reworking or transport of faunas could indicate a time of low sediment input such as during the brief cold regression that separates the Pelukian and Simpsonian transgressions. This

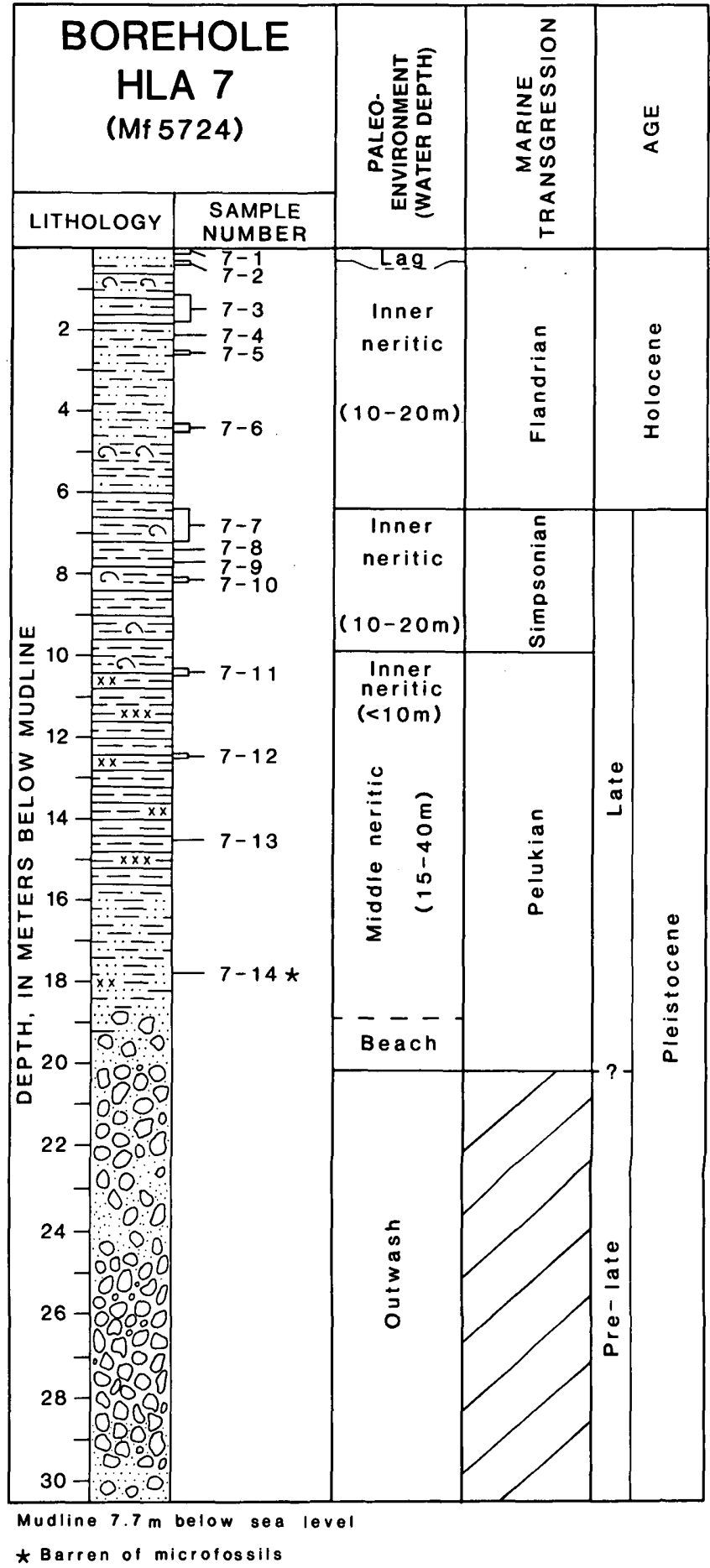

Figure 16. Lithology, sample locations, paleoenvironments, and ages of borehole HLA 7, Beaufort Sea shelf, Alaska. Paleoenvironment contacts dashed where approximate. Lithostratigraphic units and transgressions summarized in figures 4 and 5 and in figures 2 and 3 , respectively.

interval may also represent deteriorating climatic conditions during the final stages of the Pelukian transgression.

Simpsonian faunas in samples 7-10 to 7-8 contain abundant foraminiferal fauna of low to moderate diversity. The 


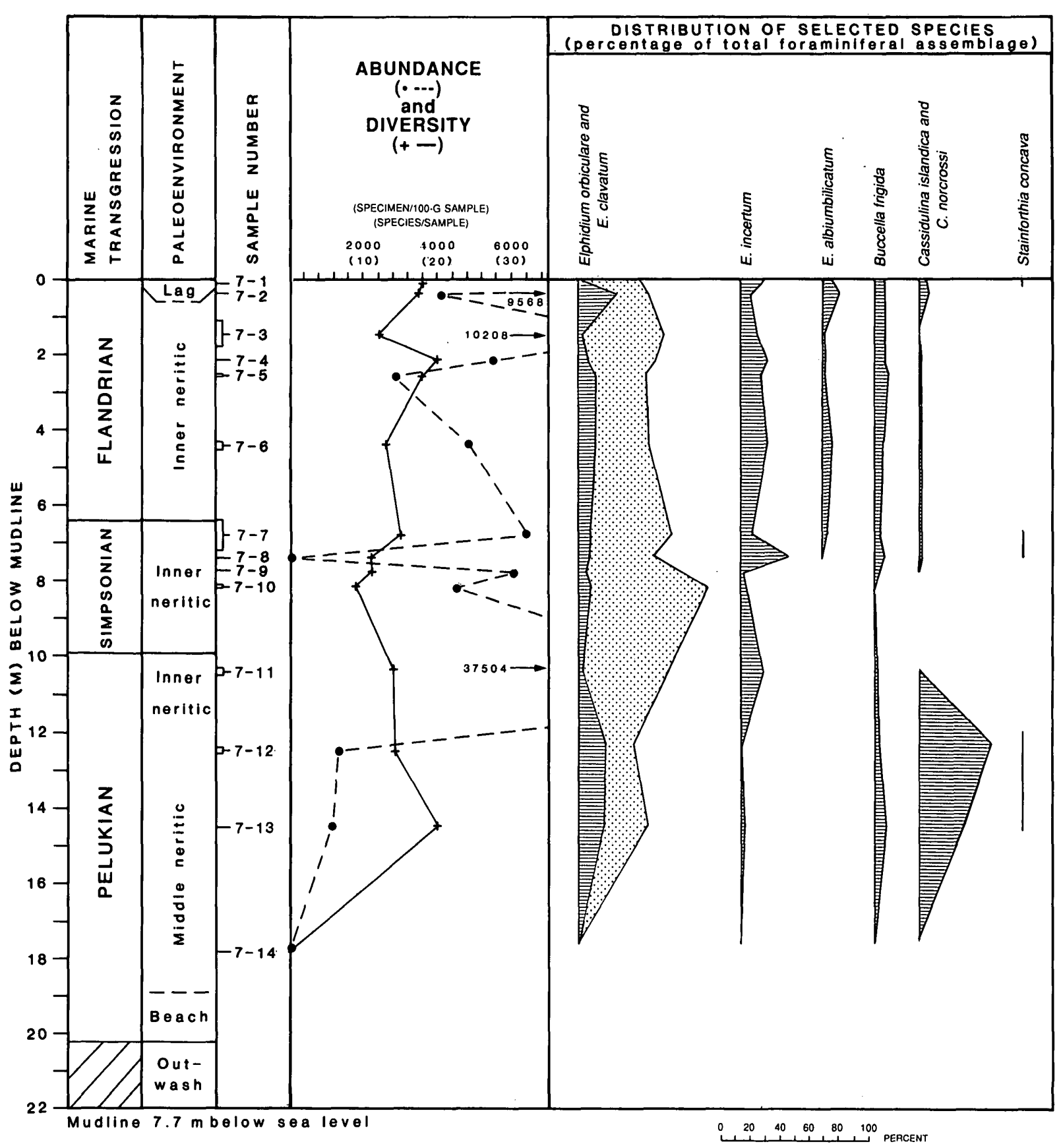

Figure 17. Benthic foraminiferal abundance (dot or number) and diversity (cross) and distribution of selective species in borehole HLA 7, Beaufort Sea shelf, Alaska. See table 6 for foraminiferal values. Paleoenvironment contacts dashed where approximate. Transgressions summarized in figures 2 and 3.

benthic foraminiferal assemblages contain rare cassidulinids, few Buccella frigida ( $\leq 6 \%$ ), and abundant elphidiums, suggesting that deposition occurred in the deep inner neritic biofacies (10-20 m). The presence of rare deeper water species suggests reworking of older Pleistocene sediments. The abundance of Elphidium incertum in sample 7-8 indicates an increase in cold, low-salinity water.

The foraminiferal assemblage in sample 7-7 is marked by a high specimen number and a moderate increase in diversity. The high specimen number is attributed to the addition of middle neritic and shallower calcareous species, presumably reworked from older deposits, and arenaceous species such as Spiroplectammina biformis and Ammotium cassis. The arenaceous species are common today in the warmer Bering Sea water mass and are occasionally found in protected embayments along the Arctic Coast. This assemblage probably represents a mixing of Simpsonian and Flandrian faunas during the onset of the 
Flandrian transgression, despite the lithologic placement of the Flandrian-Simpsonian boundary just above this sample.

The Flandrian samples, 7-6 to 7-1, contain abundant and moderately diverse foraminifers. Elphidiums are abundant, Buccella frigida makes up between 6 and 9 percent of the assemblage, and cassidulinids are rare. This composition suggests that deposition occurred in the inner shelf biofacies $(10-20 \mathrm{~m})$. The rare occurrence (less than $1 \%)$ of Spiroplectammina biformis in samples 7-3 and 7-4 may indicate a time when warmer water from the Bering Sea reached this part of the shelf. Elphidium albiumbilicatum reaches abundances of greater than 5 percent in samples 7-6, 7-2, and 7-1 and suggests an increase in low-salinity waters.

\section{BOREHOLE HLA 8 (Mf5725)}

Borehole HLA 8 was drilled north-northeast of Cross Island, approximately $25 \mathrm{~km}$ offshore (fig. 1). The $30.6 \mathrm{~m}$ recovered at the site include gravel interpreted as glacial outwash, thaw-lake deposits of organic silt with abundant wood fragments, and marine deposits that are interpreted as representing four transgressions: Wainwrightian, Pelukian, Simpsonian, and Flandrian (P.A. Smith, oral commun., 1985; fig. 18). The Wainwrightian sediments include $1.3 \mathrm{~m}$ of beach gravel, $2.0 \mathrm{~m}$ of silty sand and pebbly sand, 10.0 $\mathrm{m}$ of stiff overconsolidated clay, and $1.0 \mathrm{~m}$ of clay with wood and shell fragments. Seismic reflectors R3 and R4 (P.A. Smith, oral commun., 1985) correspond to seismic reflector surfaces 3 and 4 of Wolfe and others (1985). Pelukian sedimerits consist of $1.5 \mathrm{~m}$ of slightly sandy, clayey silt with shell and wood fragments and $5.3 \mathrm{~m}$ of silty clay. The base of the Simpsonian transgression is placed at 6.0 $\mathrm{m}$, where shell fragments appear in a clayey silt that extends from 6.0 to $1.5 \mathrm{~m}$ in the hole. Flandrian sediments include $1.0 \mathrm{~m}$ of silt and $0.5 \mathrm{~m}$ of pebbly clayey silt with sand which is part of the Holocene lag deposit that blankets the area. Depths of stratigraphic units and seismic reflectors in the borehole follow.

HLA 8

\begin{tabular}{|c|c|c|}
\hline \multirow[t]{2}{*}{ Stratigraphic unit or seismic reflector } & \multicolumn{2}{|c|}{$\begin{array}{l}\text { Depth, in meters } \\
\text { below mudline }\end{array}$} \\
\hline & Top & Bottom \\
\hline 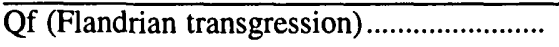 & 0.0 & 1.8 \\
\hline 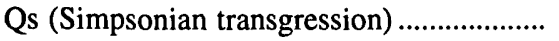 & 1.8 & 6.0 \\
\hline Qp (Pelukian transgression) & 6.0 & 12.8 \\
\hline Qw (Wainwrightian transgression) .................. & 12.8 & 27.1 \\
\hline R4 & 18.0 & \\
\hline R3 & 24.0 & \\
\hline 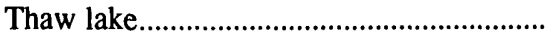 & 27.1 & 29.3 \\
\hline Undifferentiated Pleistocene outwash ......... & 29.3 & 30.6 \\
\hline
\end{tabular}

Nine samples were submitted for microfossil analysis. Except for sample 8-9, which is barren of benthic foraminifers, the samples contain common to abundant benthic foraminifers that range in age from middle Pleistocene to Holocene and represent the Wainwrightian, Pelukian, Simpsonian, and Flandrian transgressions (fig. 19, table 7). Reworked faunas are particularly evident in samples 8-3 and 8-2.

A single juvenile ostracode specimen (Candona sp.) was found in sample 8-9. This long-ranging ostracode genus probably reflects deposition during a regressive cycle or glacial interval (E.M. Brouwers, written commun., 1985). Deposition of these sediments in a thaw lake is suggested by lithology (P.A. Smith, oral commun., 1985) and is compatible with the presence of the nonmarine genus Candona.

Samples from the Wainwrightian transgression (8-8 and 8-7) are stratigraphically above the beach and nearshore sediments. Benthic foraminifers are common and moderately diverse (average 15\%). In sample 8-8, the foraminiferal assemblage is dominated by Elphidium clavatum (26\%) and E. orbiculare (24\%). In sample 8-7, the number of specimens increases slightly; Elphidium clavatum becomes more abundant (59\%), and the abundance of $E$. orbiculare declines (16\%). Few Buccella frigida are present (average 2.2\%). Although not abundant, Cassidulina islandica and $C$. norcrossi appear in samples 8-8 and 8-7. Moderate abundances of these species in association with common to abundant elphidiums indicate the middle neritic biofacies $(15-40 \mathrm{~m})$. The greater abundance of cassidulinids in sample 8-8 than in sample 8-7 implies that water depth decreases upsection. A decrease in water depth from middle neritic $(15-40 \mathrm{~m})$ to inner neritic $(10-20 \mathrm{~m})$ is also indicated by an increase in $B$. frigida and elphidiums between samples 8-8 and 8-7.

Low to moderate diversities and abundant foraminifers characterize the Pelukian assemblages in samples 8-6 to 8-4. Foraminiferal assemblages indicate water depths of less than $10 \mathrm{~m}$ and the presence of low-salinity cold water. This interpretation is supported by (1) the abundant elphidiums, particularly E. clavatum, $E$. orbiculare, and $E$. incertum, (2) few to common specimens of Buccella frigi$d a$, and (3) the absence of any middle neritic or deeper water species.

Foraminifers from Simpsonian samples 8-3 and 8-2 are similar to those in the underlying Pelukian assemblages. Elphidiums are abundant, and Buccella frigida averages less than 5 percent of the assemblage. Elphidiums include the abundant $E$. clavatum (average $49 \%$ ), common $E$. incertum (average 14\%), and rare E. orbiculare (average $0.5 \%$ ). This faunal composition indicates cold, low-salinity water and water depths of less than $10 \mathrm{~m}$. The rare deeper water species present are believed to be reworked from Pelukian sediments during the Simpsonian transgression. 
The Flandrian transgression is represented by an abundant but low diversity foraminiferal assemblage in sample 8-1. This Elphidium-dominated assemblage indicates shallow, low-salinity water $(0-10 \mathrm{~m})$. The presence of Buccella frigida (7\%) suggests, however, that water depths were probably 10 to 20 meters.

\section{BOREHOLE HLA 9 (Mf6107)}

Borehole HLA 9 was drilled in shallow water on the shoreward side of the barrier island chain, $5.6 \mathrm{~km}$ east of the mouth of the Sagavanirktok River and $4.8 \mathrm{~km}$ northwest of Duck Island (fig. 1). Sedimentary units penetrated in this

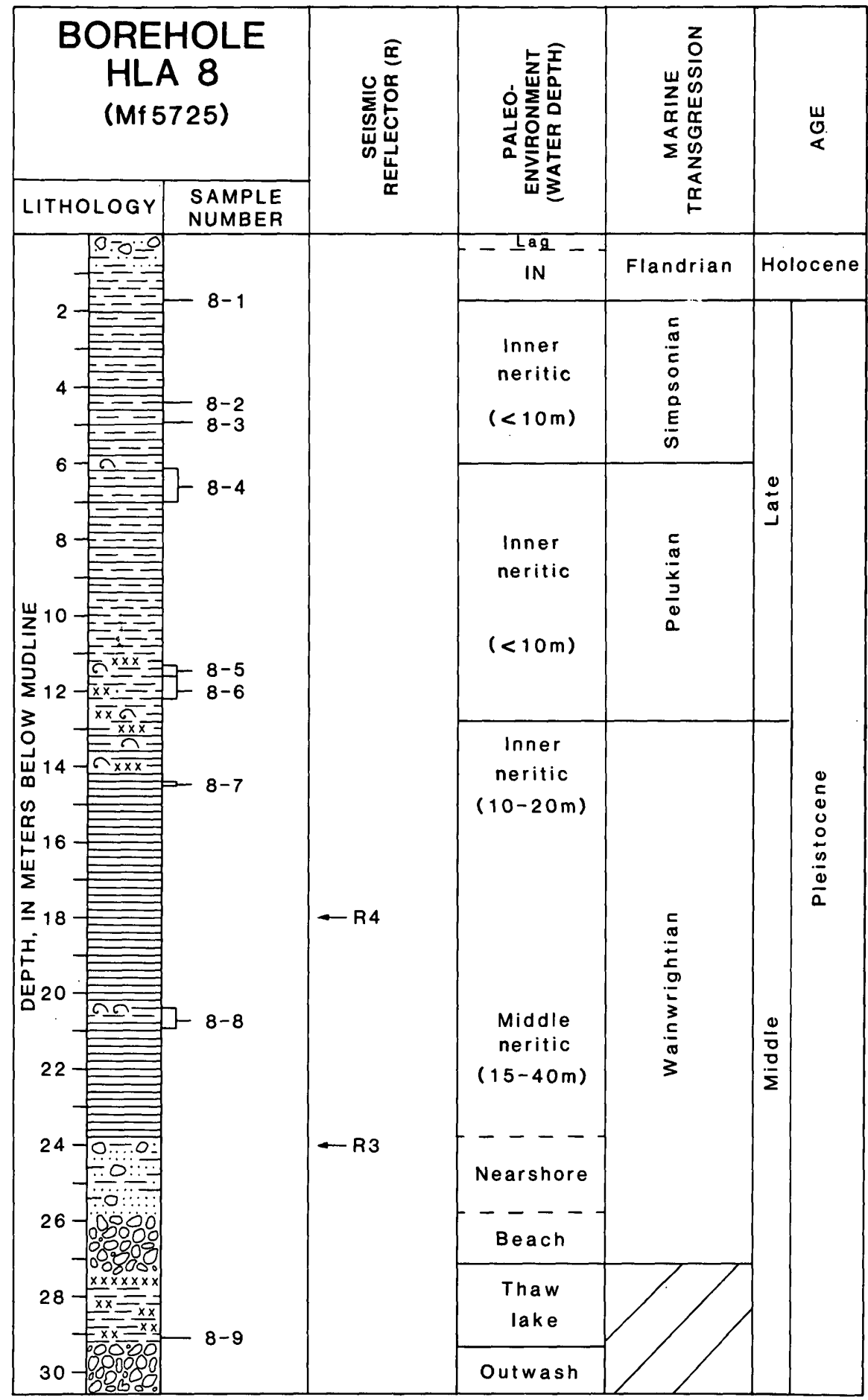

Mudline $14.0 \mathrm{~m}$ below sea level

IN - Inner neritic $(0-20 \mathrm{~m})$
Figure 18. Lithology, sample locations, paleoenvironments, and ages of borehole HLA 8, Beaufort Sea shelf, Alaska. Paleoenvironment contacts dashed where approximate. Lithostratigraphic units and transgressions summarized in figures 4 and 5 and in figures 2 and 3 , respectively. $R$, seismic reflector surface. 


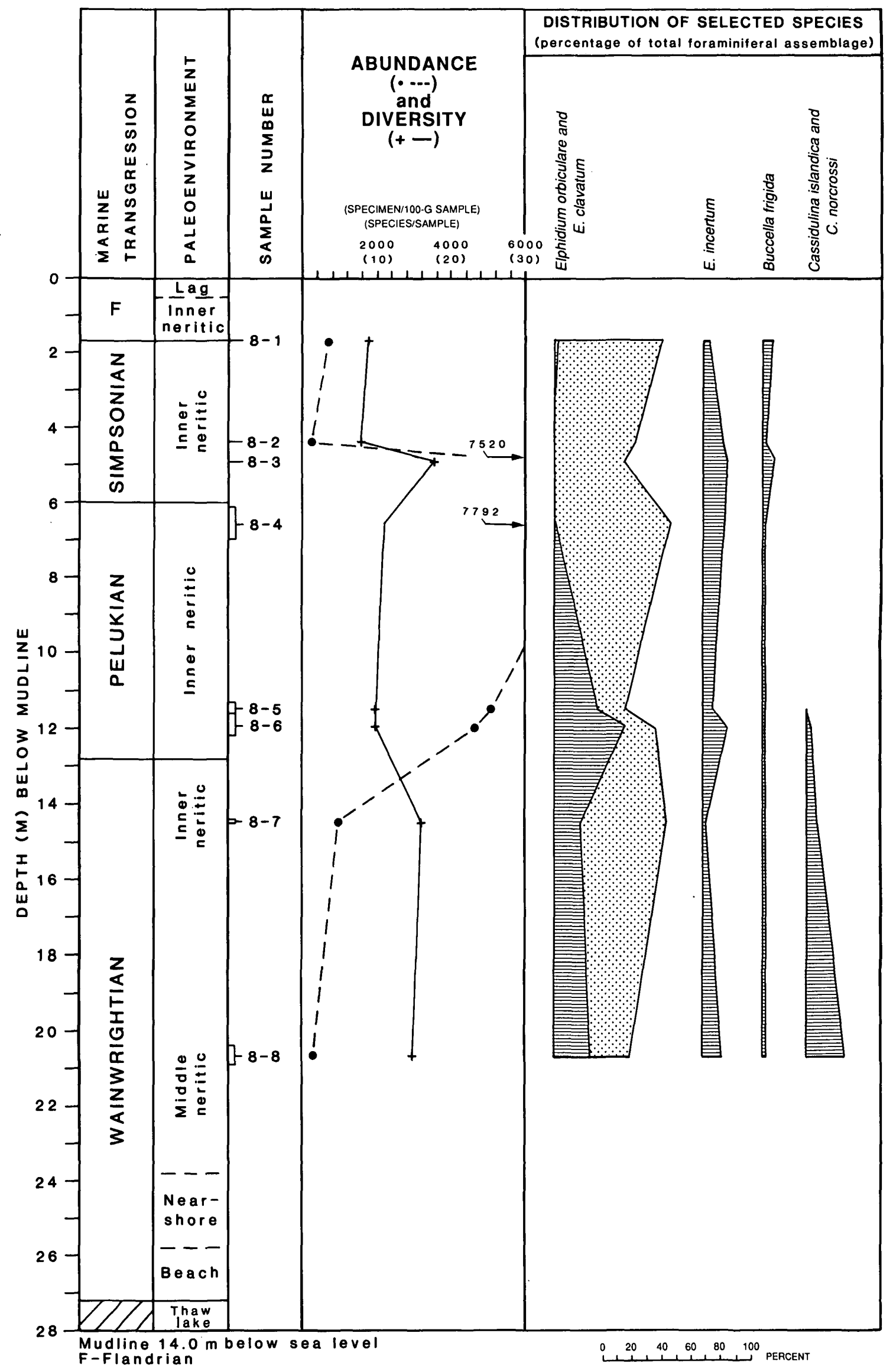


hole consist of (oldest to youngest) Shaviovik gravel unit, Maguire Islands unit, Cross Island unit, and a Holocene lag deposit (fig. 20). Seismic reflector R4, observed at $23.5 \mathrm{~m}$ near the base of the Maguire Islands unit, marks the basal part of the Pelukian transgression (P.A. Smith, oral commun., 1985). Depths of stratigraphic units and seismic reflectors in the borehole follow.

HLA 9

\begin{tabular}{|c|c|c|}
\hline \multirow{2}{*}{ Stratigraphic unit or seismic reflector } & \multicolumn{2}{|c|}{$\begin{array}{l}\text { Depth, in meters } \\
\text { below mudline }\end{array}$} \\
\hline & Top & Bottom \\
\hline Qf (Flandrian transgression) ............................. & 0.0 & 0.5 \\
\hline 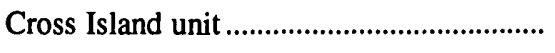 & .5 & 16.7 \\
\hline 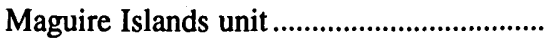 & 16.7 & 23.2 \\
\hline R4 & 23.5 & \\
\hline 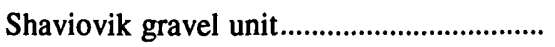 & 23.2 & 39.6 \\
\hline
\end{tabular}

Of the seven samples submitted for microfossil analysis, four contain only ostracodes (samples 9-7, 9-6, 9-2, and 9-1), one sample (9-5, table 8 ) contains both foraminifers and ostracodes, and two samples (9-4 and 9-3) are barren of both foraminifers and ostracodes. All of the samples are assigned to the Simpsonian transgression, although samples 9-2 and 9-1 may represent the Flandrian transgression.

Ostracode faunas in samples 9-7 to 9-5 have low diversity and abundance. Species present indicate shallow inner neritic depths and marked seasonal fluctuations of temperature and salinity (E.M. Brouwers, written commun., 1985). Benthic foraminifers occur only in sample 9-5, where Elphidium clavatum dominates. This species indicates that deposition occurred in the shallow inner neritic biofacies (less than $10 \mathrm{~m}$ ) in a low-salinity water mass. The presence of foraminifers in sample 9-5 suggests a slight increase in water depth and a possible increase in salinity between sample 9-5 and the underlying samples (9-7 and 9-6). The low-abundance ostracode assemblages in samples 9-2 and 9-1 contain only two species and suggest a cold estuarine environment for which E.M. Brouwers (written commun., 1985) suggests a Holocene age; however, in this paper, the samples are assigned to the Simpsonian transgression on the basis of lithology.

\section{BOREHOLE HLA 10 (Mf5726)}

Borehole HLA 10 was drilled $6.4 \mathrm{~km}$ east of Cross Island and Narwhal Island, and seaward of the barrier island

Figure 19. Benthic foraminiferal abundance (dot or number) and diversity (cross) and distribution of selective species in borehole HLA 8, Beaufort Sea shelf, Alaska. See table 7 for foraminiferal values. Paleoenvironment contacts dashed where approximate. Transgressions summarized in figures 2 and 3. chain (fig. 1). Drilling at this site recovered $32.9 \mathrm{~m}$ of sediments that consist of (oldest to youngest) Leffingwell Lagoon unit, Maguire Islands unit, Cross Island unit, Stefansson Sound unit, and a Holocene lag deposit (P.A. Smith, oral commun., 1985; fig. 21). Depths of stratigraphic units and seismic reflectors in the borehole follow.

HLA 10

\begin{tabular}{|c|c|c|}
\hline \multirow[t]{2}{*}{ Stratigraphic unit or seismic reflector } & \multicolumn{2}{|c|}{$\begin{array}{l}\text { Depth, in meters } \\
\text { below mudline }\end{array}$} \\
\hline & Top & Bottom \\
\hline Qf (Flandrian transgression) .......................... & 0.0 & 0.5 \\
\hline Stefansson Sound unit ...................................... & .5 & 3.3 \\
\hline 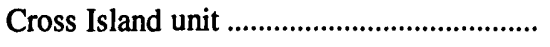 & 3.3 & 18.6 \\
\hline Maguire Islands unit .............. & 18.6 & 27.0 \\
\hline Leffingwell Lagoon unit........ & 27.0 & 32.9 \\
\hline
\end{tabular}

Benthic foraminifers are present in two intervals: The three lowest samples $(21.6-19.1 \mathrm{~m})$ and the two highest samples (4.0-3.7 m) (fig. 22, table 9). The lower group represents the Pelukian transgression, whereas the upper group represents the Simpsonian transgression (appendix 1). The interval from 16.4 to $4.8 \mathrm{~m}$, which is largely barren of microfossils, represents deltaic sedimentation that occurred during the Simpsonian transgression (P.A. Smith, written commun., 1986). Although this interval is barren of benthic foraminifers, ostracodes in samples 10-9, 10-8 and 10-5 indicate the shallow inner neritic biofacies (less than $10 \mathrm{~m}$ ) (E.M. Brouwers, written commun., 1982).

The Pelukian samples, $10-12$ to $10-10$, contain few to abundant foraminiferal faunas of low to moderate diversity. The high foraminifer number, few Buccella frigida, abundant cassidulinids ( $C$. norcrossi and $C$. islandica), and rare species of Lagena, Fissurina, and Triloculina suggest that sample 10-12 was deposited in the middle neritic biofacies $(15-40 \mathrm{~m})$. The decrease in foraminiferal number and the increase in elphidiums, especially $E$. clavatum and $E$. incertum, toward the top of this interval, indicate shallowing and cooling associated with the end of the Pelukian transgression. The shallow inner neritic biofacies (0-10 $\mathrm{m}$ ) is suggested for samples 10-11 and 10-10.

Only ostracodes are present in Simpsonian samples $10-9,10-8$, and 10-5, whereas both foraminifers and ostracodes are present in Simpsonian samples 10-2 and 10-1. The intervening samples are barren. The three ostracode species found in samples 10-9, 10-8, and 10-5 are represented by few specimens, which suggests an estuarine environment; however, reworking of older sediments cannot be ruled out (E.M. Brouwers, written commun., 1985). Foraminiferal faunas in samples 10-2 and 10-1 are abundant and moderately diverse. Elphidium clavatum and E. excavatum alba dominate. These species together with Buccella frigida (average 7\%) suggest that deposition occurred at water depths of 10 to $20 \mathrm{~m}$. Abundant E. clavatum and 


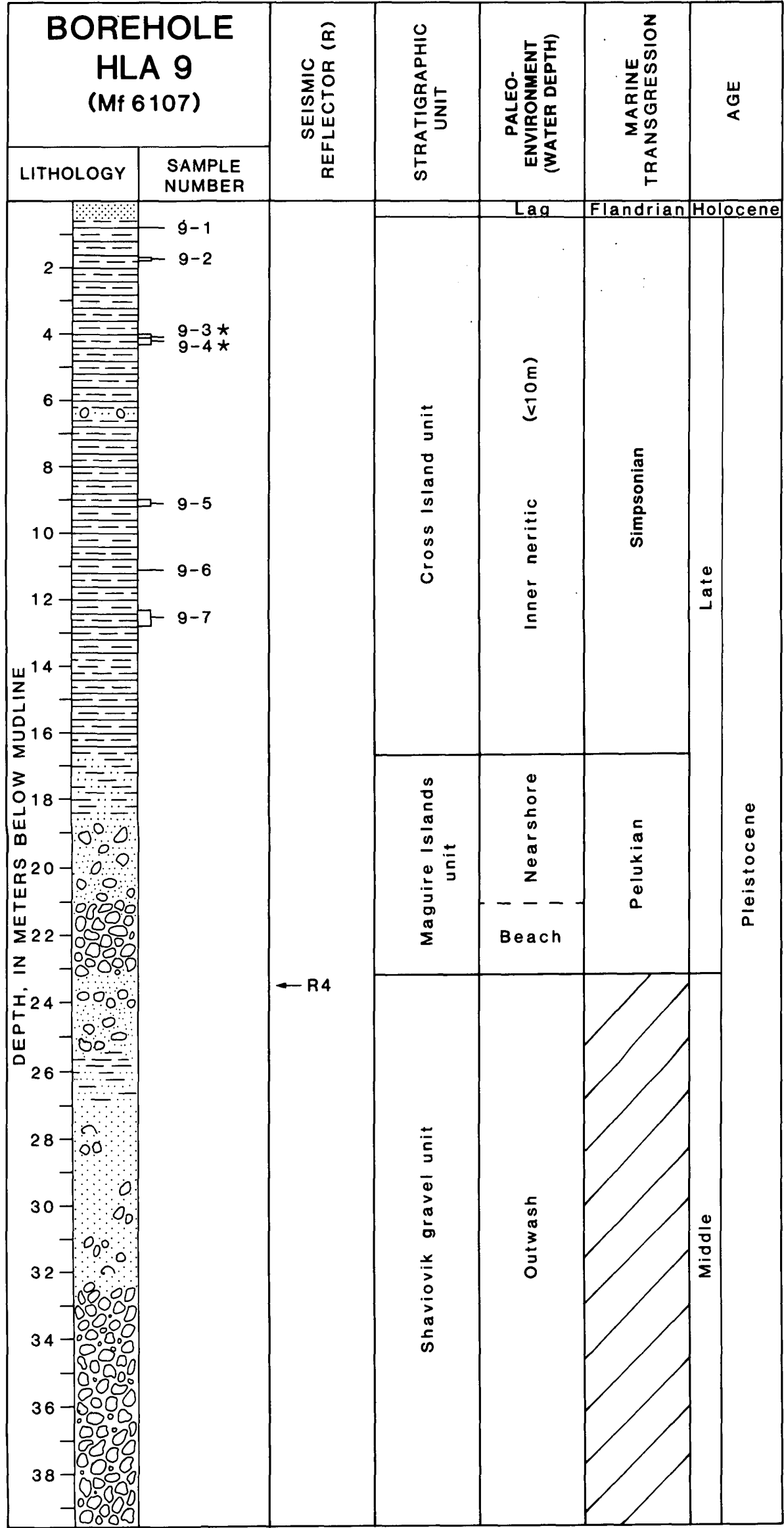

Mudline $5.3 \mathrm{~m}$ below sea level

$\star$ Barren of microfossils
Figure 20. Lithology, sample locations, lithostratigraphic units, paleoenvironments, and ages of borehole HLA 9, Beaufort Sea shelf, Alaska. Paleoenvironment contact dashed where approximate. Lithostratigraphic units and transgressions summarized in figures 4 and 5 and in figures 2 and 3 , respectively. $R$, seismic reflector surface. 


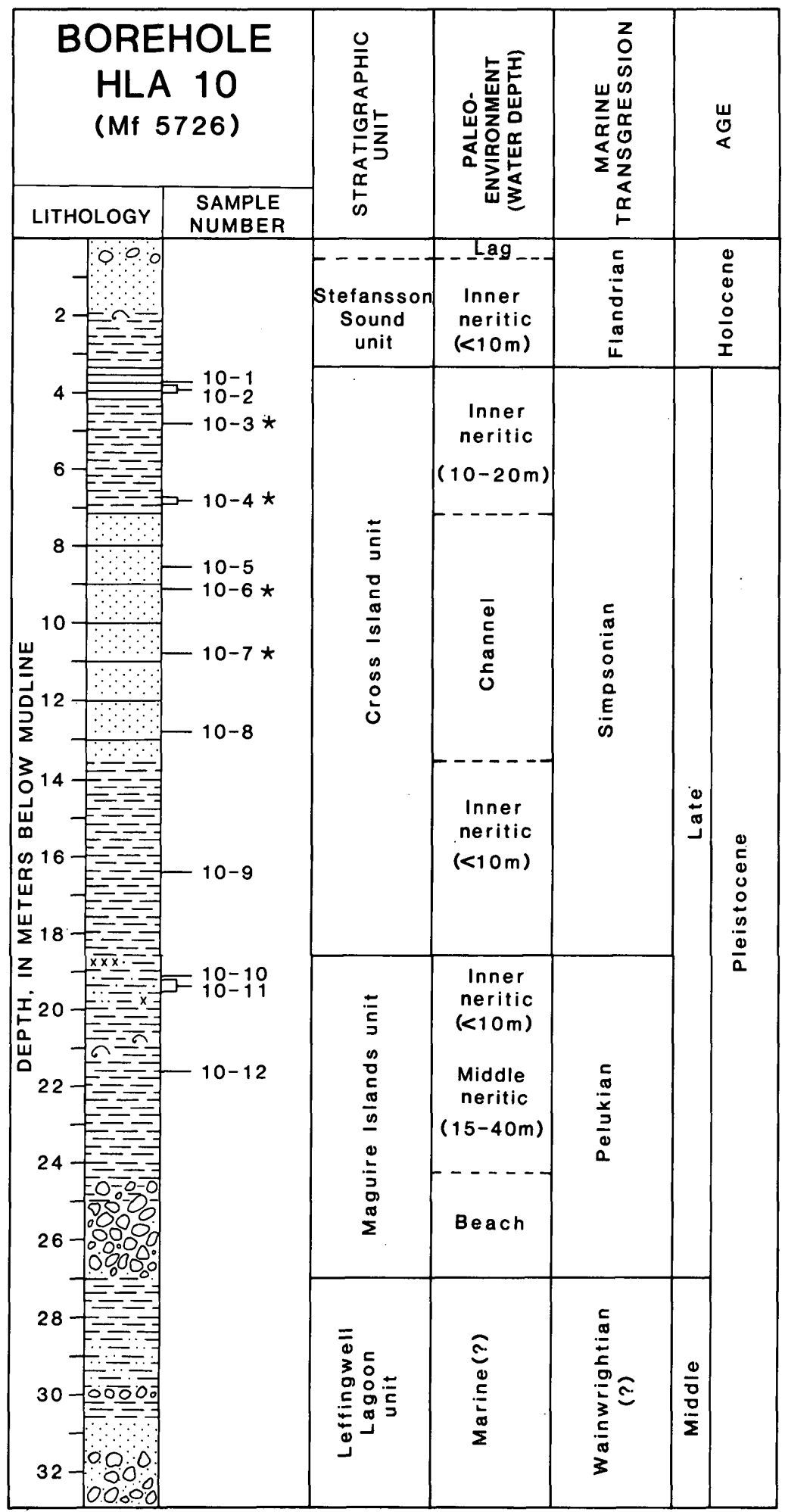

Mudline $6.5 \mathrm{~m}$ below sea level

* Barren of microfossils

Figure 21. Lithology, sample locations, lithostratigraphic units, paleoenvironments, and ages of borehole HLA 10, Beaufort Sea shelf, Alaska. Paleoenvironment contacts dashed where approximate. Lithostratigraphic units and transgressions summarized in figures 4 and 5 and in figures 2 and 3, respectively. 


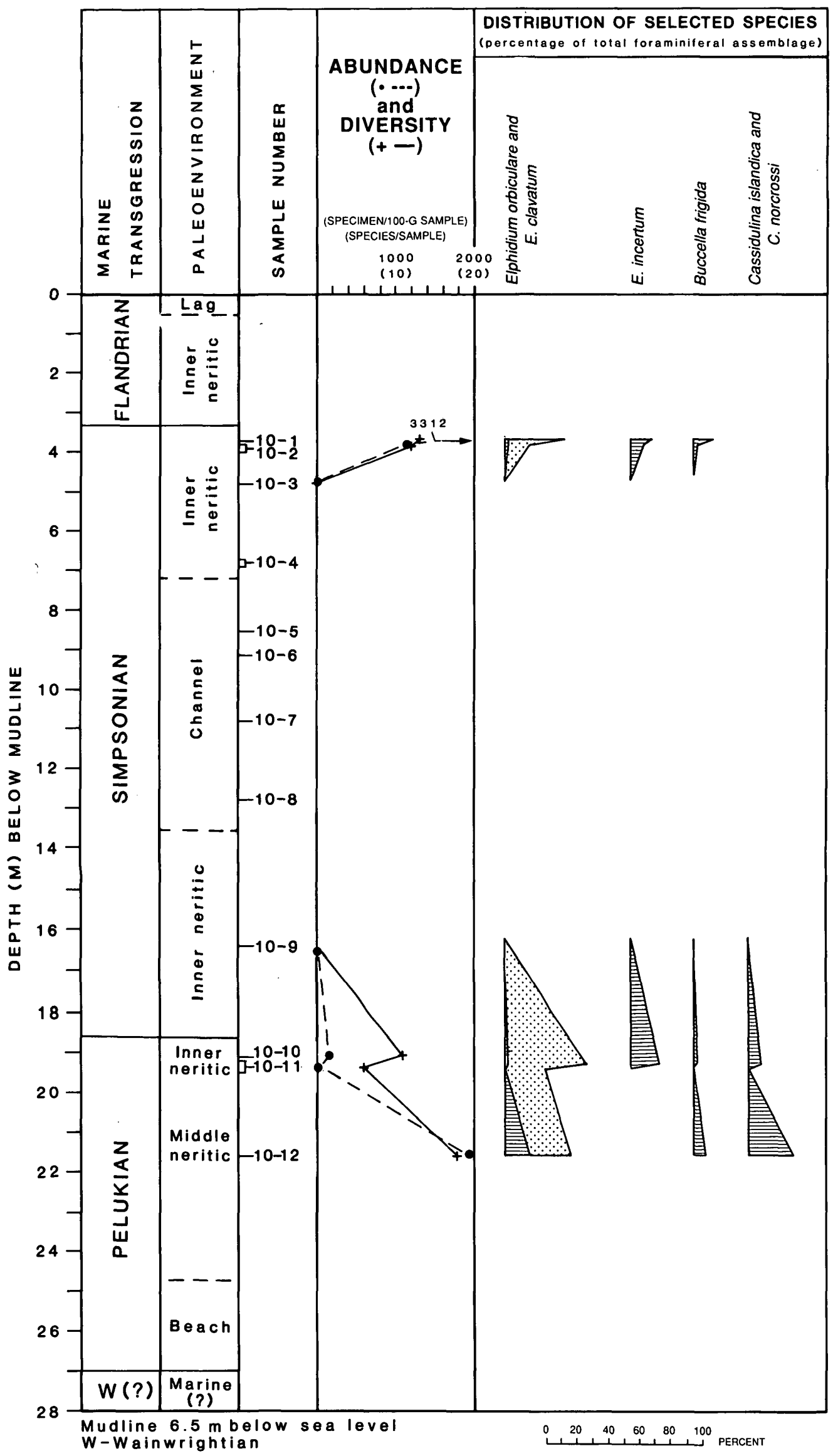

Figure 22. Benthic foraminiferal abundance (dot or number) and diversity (cross) and the distribution of selective species in borehole HLA 10, Beaufort Sea shelf, Alaska. See table 9 for foraminiferal values. Paleoenvironment contacts dashed where approximate. Transgressions summarized in figures 2 and 3. 
$E$. incertum (average $11 \%$ ) suggest cold-water temperatures. The abundant $E$. excavatum alba in these samples suggest that material has been transported from warmer, more nearshore areas or that icebergs were present. The abundant and moderately diverse ostracodes in samples 10-2 and 10-1 also suggest that deposition occurred in the inner neritic biofacies. Because the ostracode adult/juvenile ratios suggest life assemblages (E.M. Brouwers, written commun., 1985), these assemblages were probably not transported.

\section{BOREHOLE HLA 11 (Mf6108)}

Borehole HLA 11 was drilled $8.0 \mathrm{~km}$ northeast of Point Brower, shoreward of the barrier island chain (fig. 1), and penetrated $29.0 \mathrm{~m}$ of sediment. Sedimentary units recognized in this hole include (oldest to youngest) Shaviovik gravel unit, Leffingwell Lagoon unit, Maguire Islands unit, Cross Island unit, and Mikkelsen Bay unit (P.A. Smith, oral commun., 1985). A thaw lake and Holocene lag deposits were also identified (fig. 23). Fine sands at 5.0 and
Figure 23. Lithology, sample locations, lithostratigraphic units, paleoenvironments, and ages of borehole HLA 11, Beaufort Sea shelf, Alaska. Lithostratigraphic units and transgressions summarized in figures 4 and 5 and in figures 2 and 3 , respectively. $R$, seismic reflector surface.

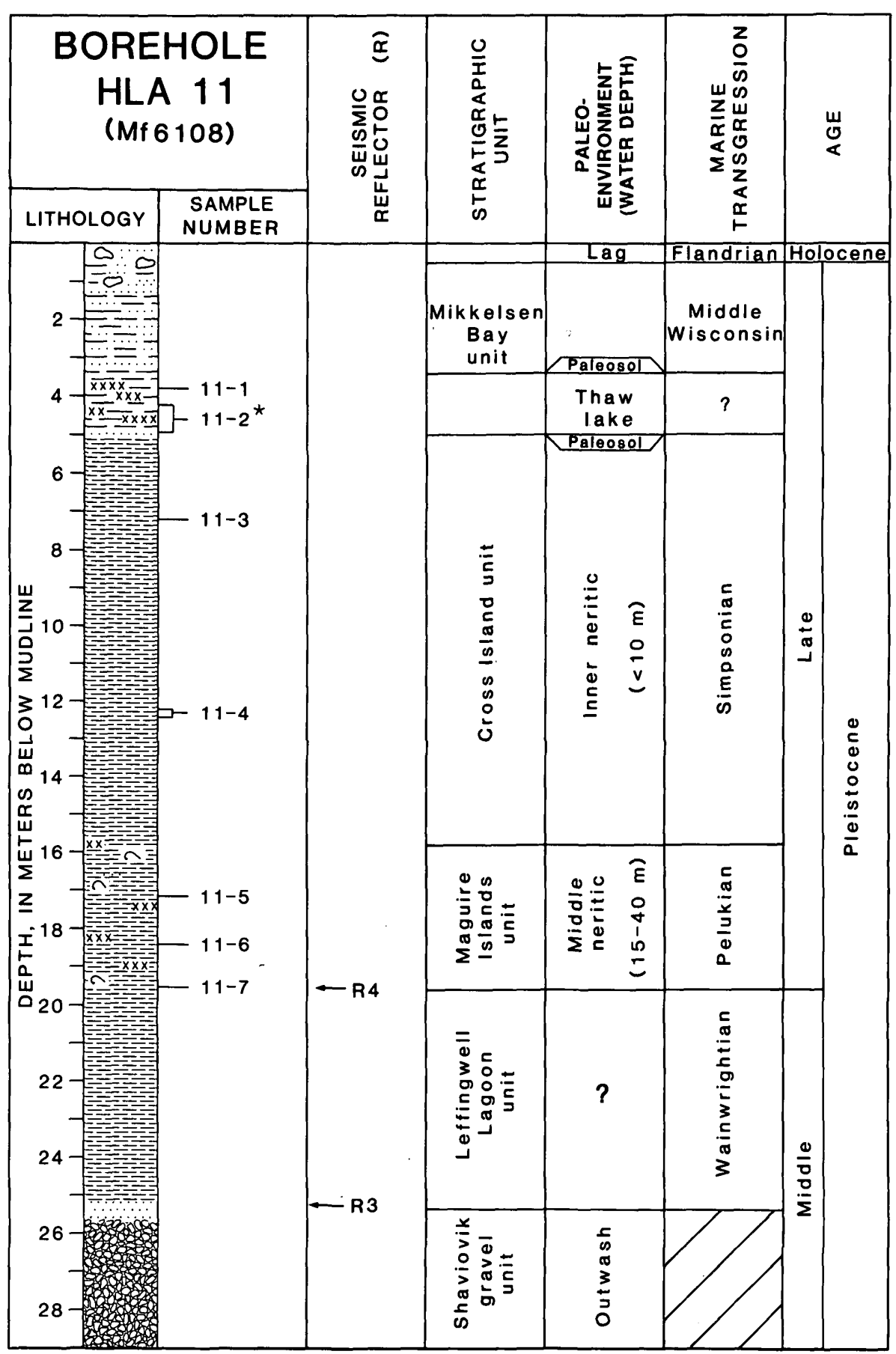

Mudline $7.5 \mathrm{~m}$ below sea level

* Barren of microfossils 
$3.4 \mathrm{~m}$ in the hole are interpreted as paleosols (P.A. Smith, oral commun., 1985). Seismic reflectors R3 and R4, noted at 25.2 and $19.5 \mathrm{~m}$, respectively, correspond to surfaces 3 and 4 of Wolfe and others (1985) (P.A. Smith, oral commun., 1985). These reflectors also approximate the base of the Leffingwell Lagoon unit (R3) and the Maguire Islands unit (R4). Sediments range in age from the middle Pleistocene to Holocene and represent the Wainwrightian, Pelukian, Simpsonian, middle Wisconsin, and Flandrian transgressions. Depths of stratigraphic units and seismic reflectors in the borehole follow.

HLA 11

\begin{tabular}{|c|c|c|}
\hline \multirow[t]{2}{*}{ Stratigraphic unit or seismic reflector } & \multicolumn{2}{|c|}{$\begin{array}{l}\text { Depth, in meters } \\
\text { below mudline }\end{array}$} \\
\hline & Top & Bottom \\
\hline Qf (Flandrian transgression) ............................ & 0.0 & 0.5 \\
\hline Mikkelsen Bay unit........... & .5 & 3.4 \\
\hline 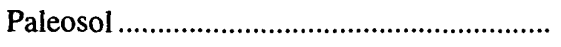 & 3.4 & \\
\hline Thaw lake......................... & 3.4 & 5.0 \\
\hline 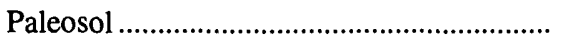 & 5.0 & \\
\hline 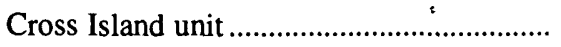 & 5.0 & 15.8 \\
\hline 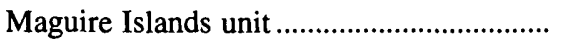 & 15.8 & 19.5 \\
\hline 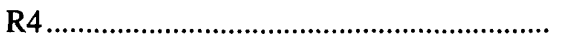 & 19.5 & \\
\hline Leffingwell Lagoon unit ..... & 19.5 & 25.2 \\
\hline R3 & 25.2 & \\
\hline 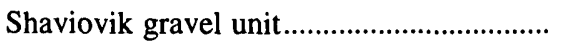 & 25.2 & 29.0 \\
\hline
\end{tabular}

Seven microfossil samples were analyzed from the Maguire Islands and Cross Island units and from thaw-lake deposits. Benthic foraminifers occur in samples 11-7 to 11-3, and 11-1 (fig. 24, table 10). Samples 11-7 to 11-5 represent the Pelukian transgression; samples 11-4 and 11-3 represent the Simpsonian transgression; sample 11-2 is barren of foraminifers and ostracodes; and sample 11-1 is questionably assigned to the middle Wisconsin transgression.

The Pelukian samples were taken stratigraphically above a fine sand (beach or nearshore deposit) and contain diverse, common to abundant foraminiferal assemblages. The foraminiferal assemblage in sample 11-7 includes abundant Elphidium clavatum (32\%) and E. orbiculare (24\%), and few specimens of Buccella frigida (3\%). Cassidulinids are moderately abundant $(22 \%)$ in this assemblage, and the fissurinids, Triloculina trihedra, and Nonionella sp. are rare, suggesting that deposition occurred in the middle neritic biofacies (15-40 m). From sample 11-6 to sample 11-5, the foraminiferal numbers increase dramatically and species diversity is greater. The abundance of most elphidiums decrease, whereas that of Cassidulina islandica increases; outer shelf species increase in diversity and abundance. These changes suggest that water depths increased, although deposition still occurred in the middle neritic biofacies $(15-40 \mathrm{~m})$.
A sharp reduction in both foraminiferal number and diversity occurs in Simpsonian samples 11-4 and 11-3. Elphidium clavatum dominates the foraminiferal assemblages, averaging 73 percent. A single, poorly preserved specimen of Cassidulina in sample 11-4 is believed to be reworked from underlying sediments. Foraminifers in this interval indicate water depths of less than 10 meters and low salinities.

The youngest interval sampled (4.9-3.8 m) lies between two paleosols (at $5.0 \mathrm{~m}$ and $3.4 \mathrm{~m}$ ). Sediments in this interval are believed to represent deposition in a thaw lake (P.A. Smith, oral commun., 1985). Sample 11-2 is barren of benthic foraminifers and ostracodes. Sample 11-1 contains a single benthic foraminifer, Elphidium clavatum, and a few ostracodes (19 specimens, 3 species). Elphidium clavatum indicates cold, shallow (0-10 m), low-salinity waters. The occurrence of this species in thaw-lake deposits is possible, either in situ or as a reworked fauna. Ostracodes in this sample include two marine and one nonmarine species (E.M. Brouwers, written commun., 1985); which could also represent an in situ or a reworked fauna. Deposition of this assemblage occurred during the Wisconsin glacial stage or during the middle Wisconsin transgression.

\section{BOREHOLE HLA 12 (Mf5727)}

Borehole HLA 12 was drilled north of Narwhal Island, approximately $6 \mathrm{~km}$ offshore (fig. 1). Sedimentary units recognized in this hole consist of (oldest to youngest) North Star sand unit, Staines River unit, Duchess sand unit, Leffingwell Lagoon unit, Maguire Islands unit, Cross Island unit, and a Holocene lag deposit (P.A. Smith, oral commun., 1985; fig. 25). Seismic reflector surfaces 3 and 4 of Wolf and others (1985) are recognized at $29.0 \mathrm{~m}(\mathrm{R} 3)$ and $18.5(\mathrm{R} 4)$ in the hole (P.A. Smith, oral commun., 1985; fig. 25). Reflector $\mathrm{R} 3$ is $6.7 \mathrm{~m}$ above the base of the Wainwrightian sediments. Reflector R4 coincides with the boundary between the Leffingwell Lagoon and the Maguire Islands units at the beginning of the Pelukian transgression. Depths of stratigraphic units and seismic reflectors in the borehole follow.

HLA 12

\begin{tabular}{|c|c|c|}
\hline \multirow{2}{*}{ Stratigraphic unit or seismic reflector } & \multicolumn{2}{|c|}{$\begin{array}{l}\text { Depth, in meters } \\
\text { below mudline }\end{array}$} \\
\hline & Top & Bottom \\
\hline Qf (Flandrian transgression) ............................ & 0.0 & 0.5 \\
\hline Cross Island unit .......... & .5 & 2.9 \\
\hline Maguire Islands unit .......... & 2.9 & 18.5 \\
\hline R4 & 18.5 & \\
\hline 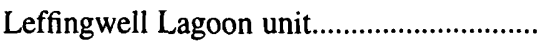 & 18.5 & 35.7 \\
\hline R3 & 29.0 & \\
\hline 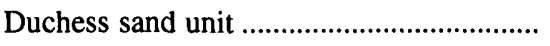 & 35.7 & 50.0 \\
\hline 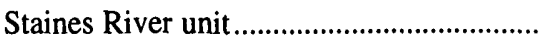 & 50.0 & 52.5 \\
\hline 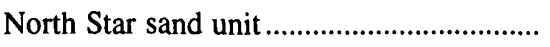 & 52.5 & 91.7 \\
\hline
\end{tabular}


Sixteen microfossil samples were taken from the clayey silts and micaceous silts of the Leffingwell Lagoon, Maguire Islands, and Cross Island units between 29.1 and 1.4 $\mathrm{m}$ in the borehole. Benthic foraminifers are present throughout the sample interval (fig. 26, table 11). The four benthic foraminiferal assemblages recognized in borehole HLA 12

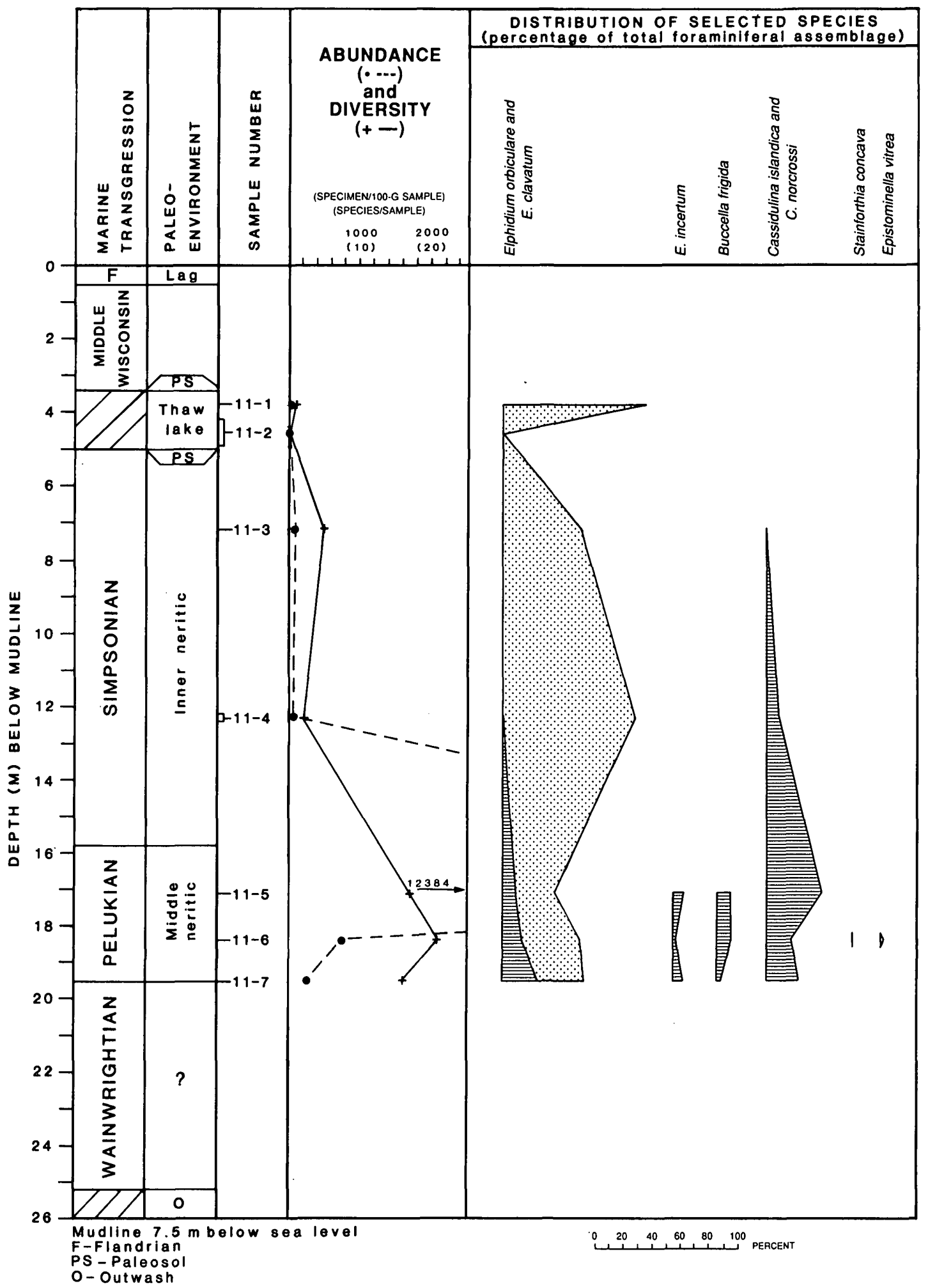

Figure 24. Benthic foraminiferal abundance (dot or number) and diversity (cross) and distribution of selective species in borehole HLA 11, Beaufort Sea shelf, Alaska. See table 10 for foraminiferal values. Transgressions summarized in figures 2 and 3. 


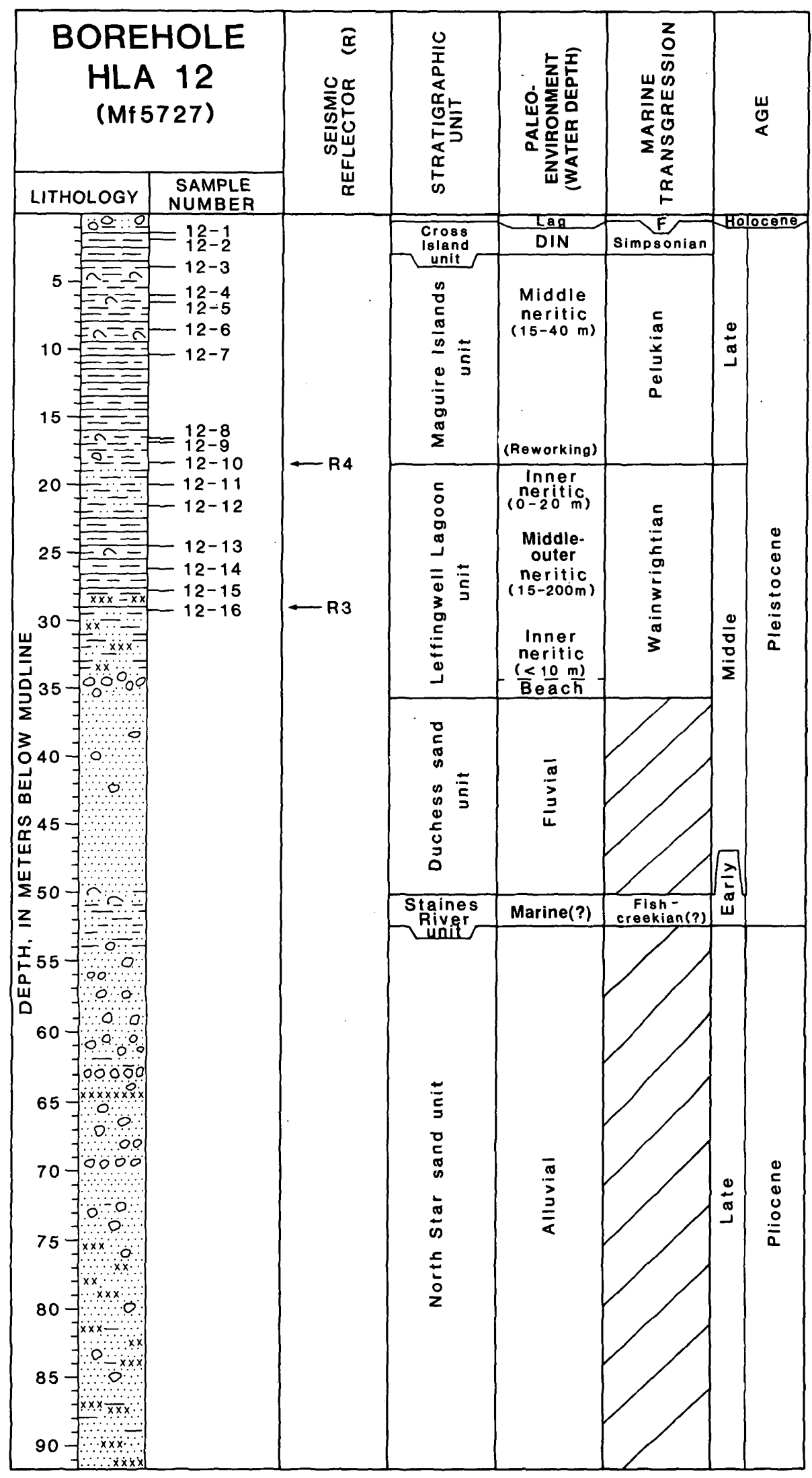

Mudline $15.2 \mathrm{~m}$ below sea level F-Flandrian

DIN-Deep inner neritic (10-20m)
Figure 25. Lithology, sample locations, lithostratigraphic units, paleoenvironments, and ages of borehole HLA 12, Beaufort Sea shelf, Alaska. Paleoenvironment contact dashed where approximate. Lithostratigraphic units and transgressions summarized in figures 4 and 5 and in figures 2 and 3 , respectively. $R$, seismic reflector surface.
Figure 26. Benthic foraminiferal abundance (dot or number) and diversity (cross) and distribution of selective species in borehole HLA 12, Beaufort Sea shelf, Alaska. See table 11 for foraminiferal values. Paleoenvironment contact dashed where approximate. Transgressions summarized in figures 2 and 3. 
BOREHOLE HLA 12 (Mf5727)

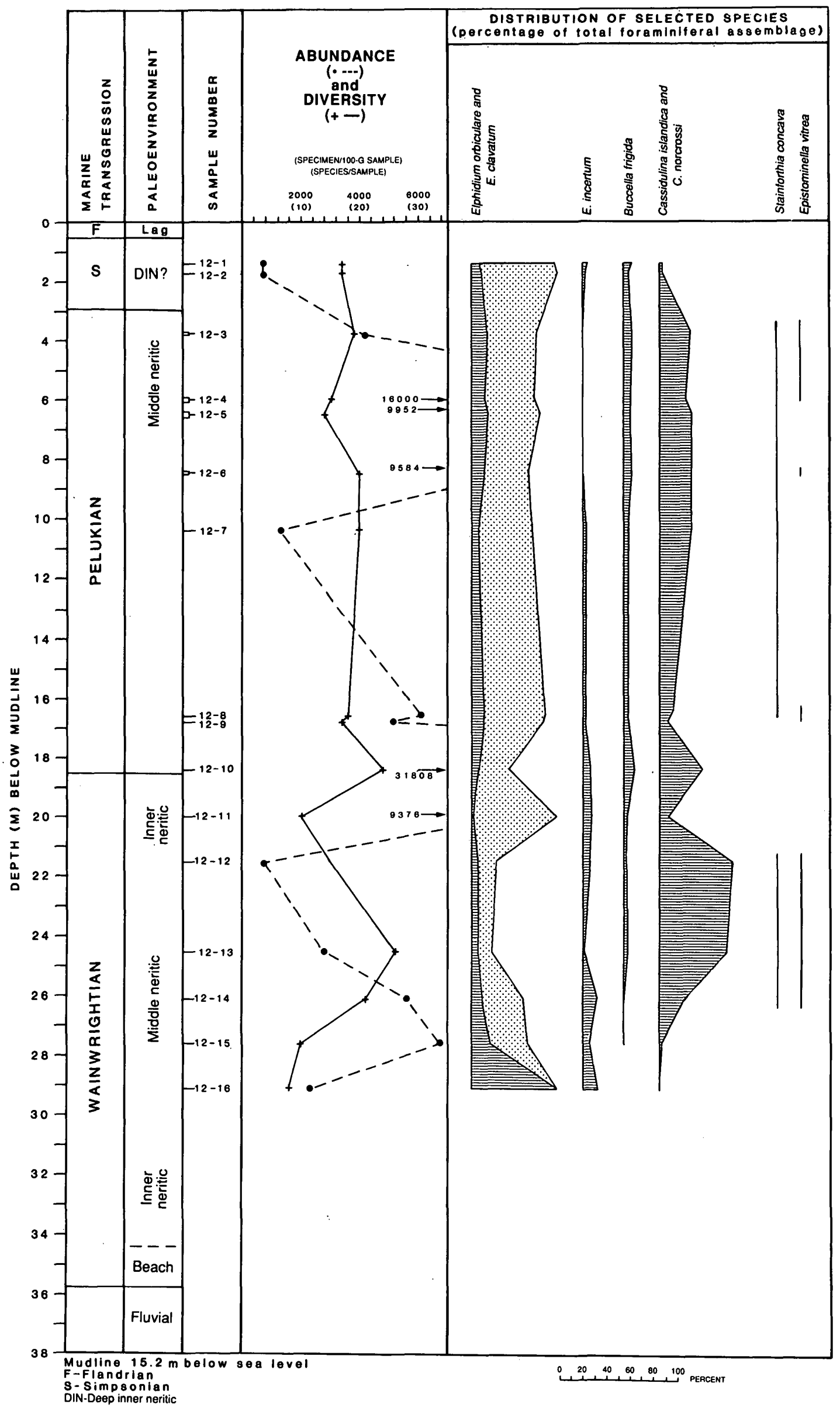


represent deposition during the Wainwrightian, Pelukian, and Simpsonian transgressions.

Wainwrightian faunas, samples $12-16$ to $12-11$, are characterized by abundant and moderately to highly diverse foraminiferal assemblages. The lowest samples are dominated by Elphidium orbiculare (sample 12-16), E. nanum (sample 12-15), and E. clavatum (sample 12-15). The colder water species $E$. incertum is common in sample 12-16 and decreases in the overlying samples. These assemblages indicate shallow inner neritic depths and cold, low-salinity water.

Foraminiferal assemblages in samples $12-14$ to $12-12$ contain a well-developed middle neritic fauna. Dominant foraminiferal species include Cassidulina norcrossi and $C$. islandica (average 47\%) and common elphidiums. Rare outer neritic and upper bathyal species, which make up less than 5 percent of the fauna, include species such as Stainforthia concava and Epistominella vitrea and species of Lagena, Fissurina, and Parafissurina. Today these forms are most commonly associated with the outer shelf and upper slope water masses. These assemblages also contain rare occurrences of Eggerella advena, which today signifies the presence of the warmer Bering Sea water mass (common at middle and outer neritic depths). Although few in number, the outer neritic to upper bathyal species suggest that deposition may have occurred in the deeper part of the middle neritic biofacies and possibly at depths greater than $40 \mathrm{~m}$.

An abundant, low-diversity foraminiferal assemblage dominated by elphidiums characterizes sample 12-11. This assemblage suggests deposition occurred as water depths decreased to inner neritic depths during the climatic cooling near the end of the Wainwrightian transgression.

Pelukian faunas in samples 12-10 to 12-3 include abundant, highly to moderately diverse foraminifers. The basal sample in this group (12-10) is characterized by a high foraminiferal number and high diversity. Species present are common to either the Wainwrightian or Pelukian assemblages. This faunal composition suggests that the sample represents the early part of the Pelukian transgression, when erosion of older Wainwrightian sediments resulted in mixing of the older faunas with the in situ Pelukian faunas. The remaining Pelukian samples are characterized by abundant elphidiums and cassidulinids (average 24\%), few Buccella frigida (average 5\%), and rare outer neritic species. The assemblage indicates that deposition occurred in the middle neritic biofacies $(15-40 \mathrm{~m})$ and that there was considerable transport from the inner neritic biofacies.

Simpsonian faunas in samples 12-2 and 12-1 are characterized by abundant foraminiferal assemblages and moderate species diversities. Foraminiferal assemblages contain abundant elphidiums, few Buccella frigida (average 6.1\%), and few cassidulinids (4.2\%). Elphidium clavatum is particularly abundant in these assemblages, averaging 65 percent of the fauna. The assemblages indicate that deposition occurred in the inner neritic biofacies at water depths of 10 to $20 \mathrm{~m}$.

\section{BOREHOLE HLA 13 (Mf6109)}

Borehole HLA 13 was drilled $4.0 \mathrm{~km}$ northeast of Point Brouwer on the shoreward side of the barrier island chain (fig. 1). A total of $30.9 \mathrm{~m}$ of sediment was recovered at this site (fig. 27). Sedimentary units recognized include (oldest to youngest) Shaviovik gravel unit, Maguire Islands unit, and Cross Island unit (P.A. Smith, written commun., 1985). Seismic reflector R4 (surface 4 of Wolf and others, 1985) is present at $15.2 \mathrm{~m}$ in the hole in sediments assigned to the Pelukian transgression. A second seismic reflector ( $R$ ?) is noted at $13.5 \mathrm{~m}$ also in sediments assigned to the Pelukian transgression but does not seem to correlate with any previously identified reflectors. Depths of stratigraphic units and seismic reflectors in the borehole follow.

HLA 13

\begin{tabular}{|c|c|c|}
\hline \multirow{2}{*}{ Stratigraphic unit or seismic reflector } & \multicolumn{2}{|c|}{$\begin{array}{l}\text { Depth, in meters } \\
\text { below mudline }\end{array}$} \\
\hline & Top & Bottom \\
\hline 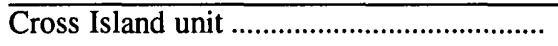 & 0.0 & 9.8 \\
\hline Maguire Islands unit .......... & 9.8 & 17.0 \\
\hline 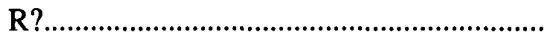 & 13.5 & \\
\hline R4 & 15.2 & \\
\hline 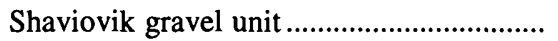 & 17.0 & 30.9 \\
\hline
\end{tabular}

Five samples were examined for microfossils: two from the Maguire Islands unit, and three from the Cross Island unit. Benthic foraminifers are present in all the samples except 13-2, which is barren of microfossils (fig. 28, table 12). The two lower samples represent the Pelukian transgression, and the others represent the Simpsonian transgression.

The two species of benthic foraminifers in the oldest Pelukian sample at $13.6 \mathrm{~m}$ are represented by 23 specimens. Elphidium excavatum alba (9\%) and $E$. frigidum $(91 \%)$ indicate a shallow nearshore marine environment with water depths of less than $10 \mathrm{~m}$ and low salinities. The presence of aberrant forms of $E$. frigidum suggests that the environment was marginal marine. Two nonmarine ostracode species (four specimens) that were also found in sample 13-5 indicate a cold temperate climate, warmer than today (E.M. Brouwers, written commun., 1982). Deposition is interpreted as occurring in a thaw lake or a very shallow nearshore marine environment.

Sample 13-4, which also represents the Pelukian transgression, contains abundant and diverse benthic foraminifers. The foraminiferal assemblage is dominated by Elphidium clavatum (43\%) and Cassidulina islandica (33\%). Few Buccella frigida (4\%) and E. orbiculare (7\%) 
Figure 27. Lithology, sample locations, lithostratigraphic units, paleoenvironments, and ages of borehole HLA 13, Beaufort Sea shelf, Alaska. Paleoenvironment contacts dashed where approximate. Lithostratigraphic units and transgressions summarized in figures 4 and 5 and in figures 2 and 3 , respectively. $\mathrm{R}$, seismic reflector surface.

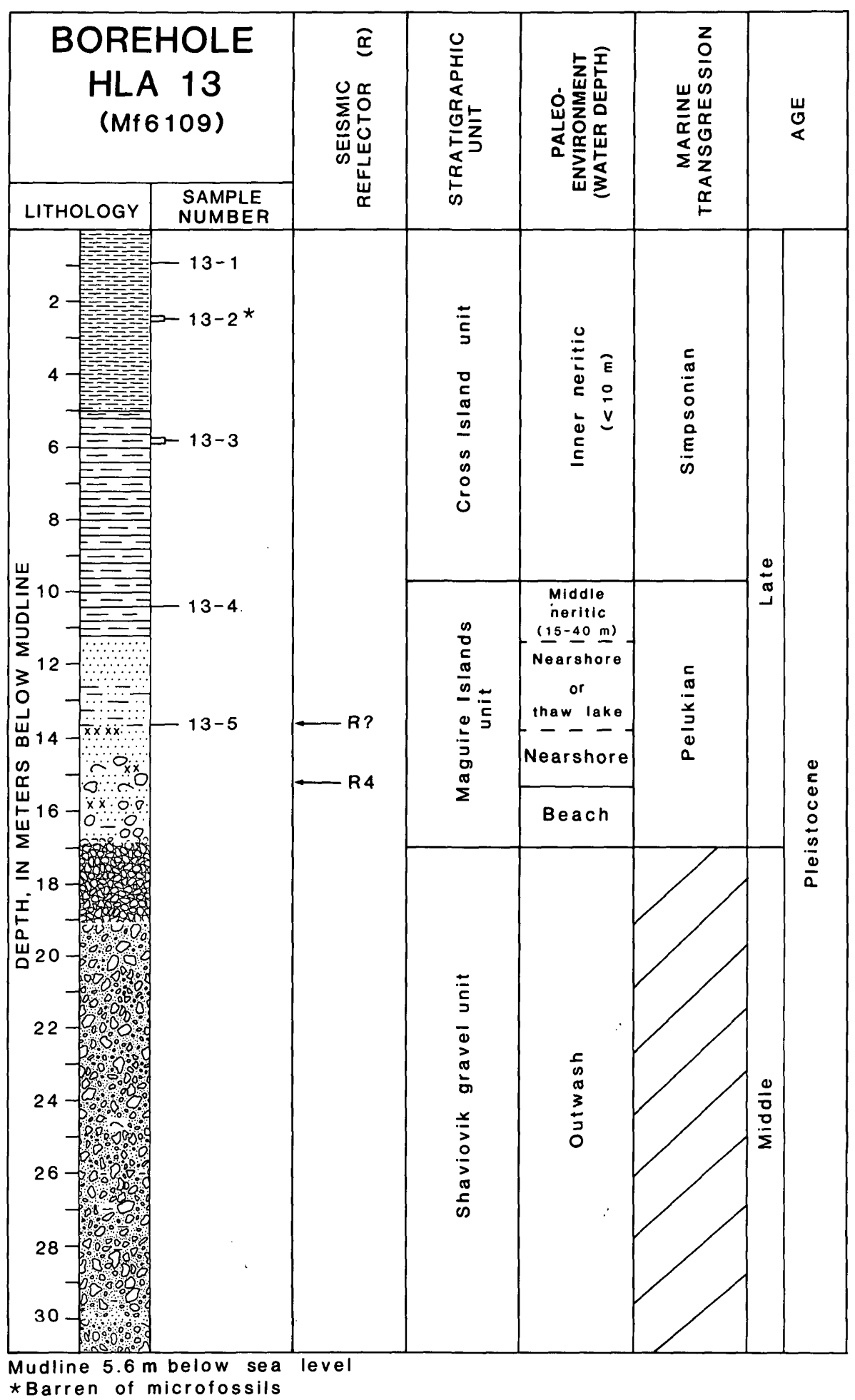

are also present. The remainder of the assemblage is represented by numerous species with few to rare specimens. These species are common to the middle neritic and shallower biofacies. This composition suggests that deposition occurred in the middle neritic biofacies at water depths of 15 to $40 \mathrm{~m}$.

Foraminiferal assemblages in the Simpsonian samples 13-3 and 13-1 contain few to rare specimens and have a low diversity. These assemblages indicate that deposition occurred in the shallow inner neritic biofacies (0-10 m). Elphidium clavatum dominates sample 13-3. Other species present include $E$. excavatum alba and $E$. nanum. Elphidium clavatum and Elphidium spp. (probably a juvenile specimen of $E$. orbiculare) compose the entire fauna of sample 13-1. These Elphidium species are not age diagnostic, but because borehole HLA 13 was drilled in a 
boulder patch having little to no Holocene sediment (P.A. Smith, oral commun., 1985), samples 13-3 to 13-1 are assigned to the Simpsonian transgression.

\section{BOREHOLE HLA 14 (Mf5728)}

Borehole HLA 14 was drilled $6.9 \mathrm{~km}$ northwest of Tigvariak Island near the mouth of the Shaviovik River, shoreward of the barrier island chain (fig. 1). Sedimentary units encountered in borehole HLA 14 consist of (oldest to youngest) Shaviovik gravel unit, Maguire Islands unit, and
Stefansson Sound unit (P.A. Smith, written commun., 1986; fig. 29). The lower boundary of the Maguire Islands unit coincides with the position of seismic reflector R4 (surface 4 of Wolf and others, 1985). A faint seismic reflector ( $R$ ?) is also noted at $13.6 \mathrm{~m}$, just below sediments identified as a thaw lake $(13.6-8.8 \mathrm{~m})$. This reflector is stratigraphically lower in the section than the unnamed reflector in HLA 13 and is not correlative with it. The basal Holocene seismic reflector (Wolf and others, 1985) is recognized at $4.5 \mathrm{~m}$ in the hole (R5) and is near the lower boundary of the Stefansson Sound unit. Depths of stratigraphic units and seismic reflectors in the borehole follow.

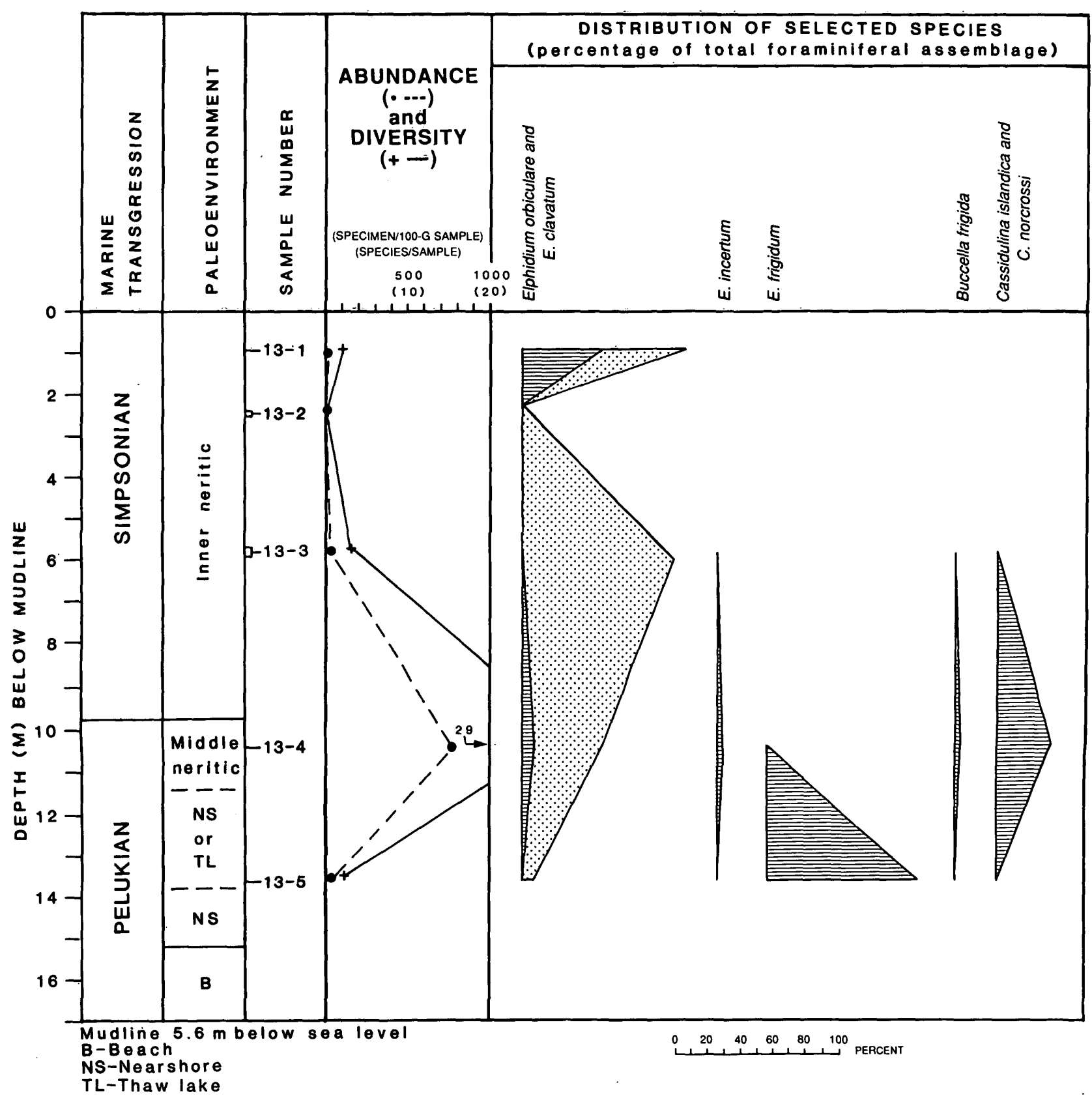

Figure 28. Benthic foraminiferal abundance (dot or number) and diversity (cross) and distribution of selective species in borehole HLA 13, Beaufort Sea shelf, Alaska. See table 12 for foraminiferal values. Paleoenvironment contacts dashed where approximate. Transgressions summarized in figures 2 and 3. 
HLA 14

\begin{tabular}{|c|c|c|}
\hline \multirow{2}{*}{ Stratigraphic unit or seismic reflector } & \multicolumn{2}{|c|}{$\begin{array}{l}\text { Depth, in meters } \\
\text { below mudline }\end{array}$} \\
\hline & Top & Bottom \\
\hline 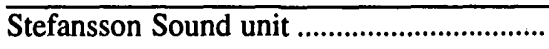 & 0.0 & 4.9 \\
\hline R5 & 4.5 & \\
\hline Maguire Islands unit & 4.9 & 19.1 \\
\hline $\mathrm{R} ? \ldots \ldots \ldots$ & 13.6 & \\
\hline R4 & 19.1 & \\
\hline 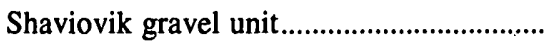 & 19.1 & 30.7 \\
\hline
\end{tabular}

Eight samples from borehole HLA 14 were examined for microfossils. Samples 14-7 and 14-4 to 14-1 contain benthic foraminifers and ostracodes, whereas samples 14-6 and 14-5 contain only ostracodes (fig. 30, table 13). Sample $14-6 \mathrm{~A}(13.6 \mathrm{~m})$ is barren of calcareous microfossils but contains abundant plant fragments. The fossiliferous assemblages are late Pleistocene to Holocene in age and represent the Pelukian and Flandrian transgressions.

Benthic foraminifers in the oldest Pelukian sample, 14-7, are few in number (54 specimens) and have low diversity (10 species). The foraminiferal assemblage contains few
Figure 29. Lithology, sample locations, lithostratigraphic units, paleoenvironments, and ages of borehole HLA 14, Beaufort Sea shelf, Alaska. Lithostratigraphic units and transgressions summarized in figures 4 and 5 and in figures 2 and 3 , respectively. $R$, seismic reflector surface.

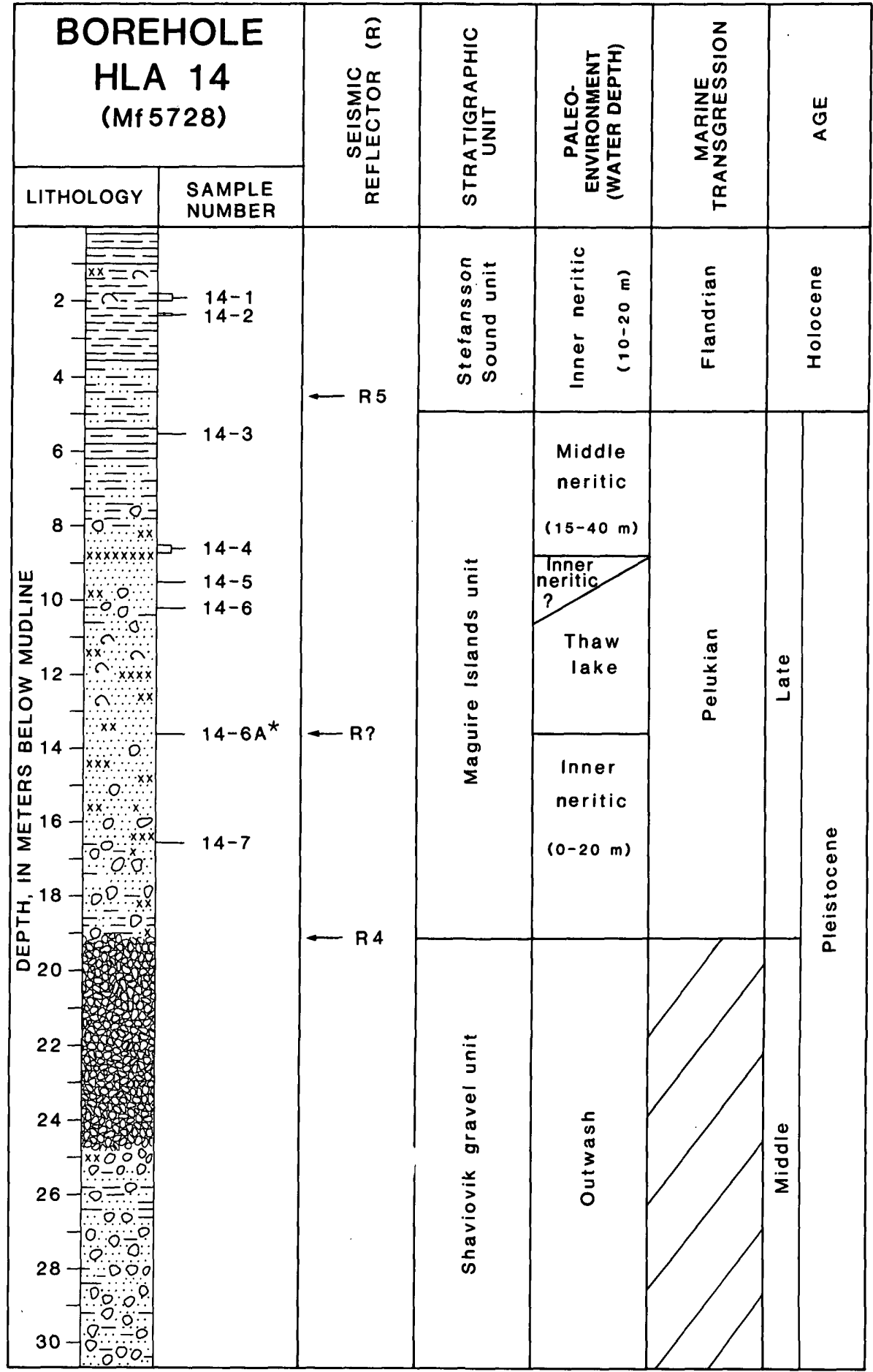

Mudline $6.5 \mathrm{~m}$ below sea level

* Barren of microfossils 
elphidiums (43 specimens, $80 \%$ ), rare Buccella frigida (5 specimens, $9 \%$ ), and rare cassidulinids (1 specimen, $2 \%$ ). Elphidiums are dominated by Elphidium orbiculare (20\%) and $E$. incertum (20\%). Also present are E. clavatum (15\%) and questionable $E$. excavatum alba $(11 \%)$, although the latter may actually be worn specimens of $E$. clavatum. This assemblage suggests that deposition occurred in the inner neritic biofacies $(0-20 \mathrm{~m})$, probably shallow inner neritic biofacies $(0-10 \mathrm{~m})$ and cold water.

Stratigraphically higher Pelukian samples $14-6$ and 14-5 contain abundant plant fragments and rare ostracodes. Ostracodes in sample 14-6 include fragments of a nonmarine species, fragments of two eurytopic species, and one middle neritic species. The composition of the ostracode assemblage in sample 14-5 is evenly divided between the middle neritic (Krithe glacialis, two specimens) and shallow inner neritic to estuarine species (Paracyprideis pseudopunctilla$t a$, two specimens) (E.M. Brouwers, written commun., 1985). Brouwers believes the middle neritic species are in place and the other specimens are transported or reworked. The absence of benthic foraminifers, and the abundance of plant material and sand with minor amounts of clay and silt, suggests instead that the middle neritic species are reworked into thaw lake or shallow marine or estuarine deposits.

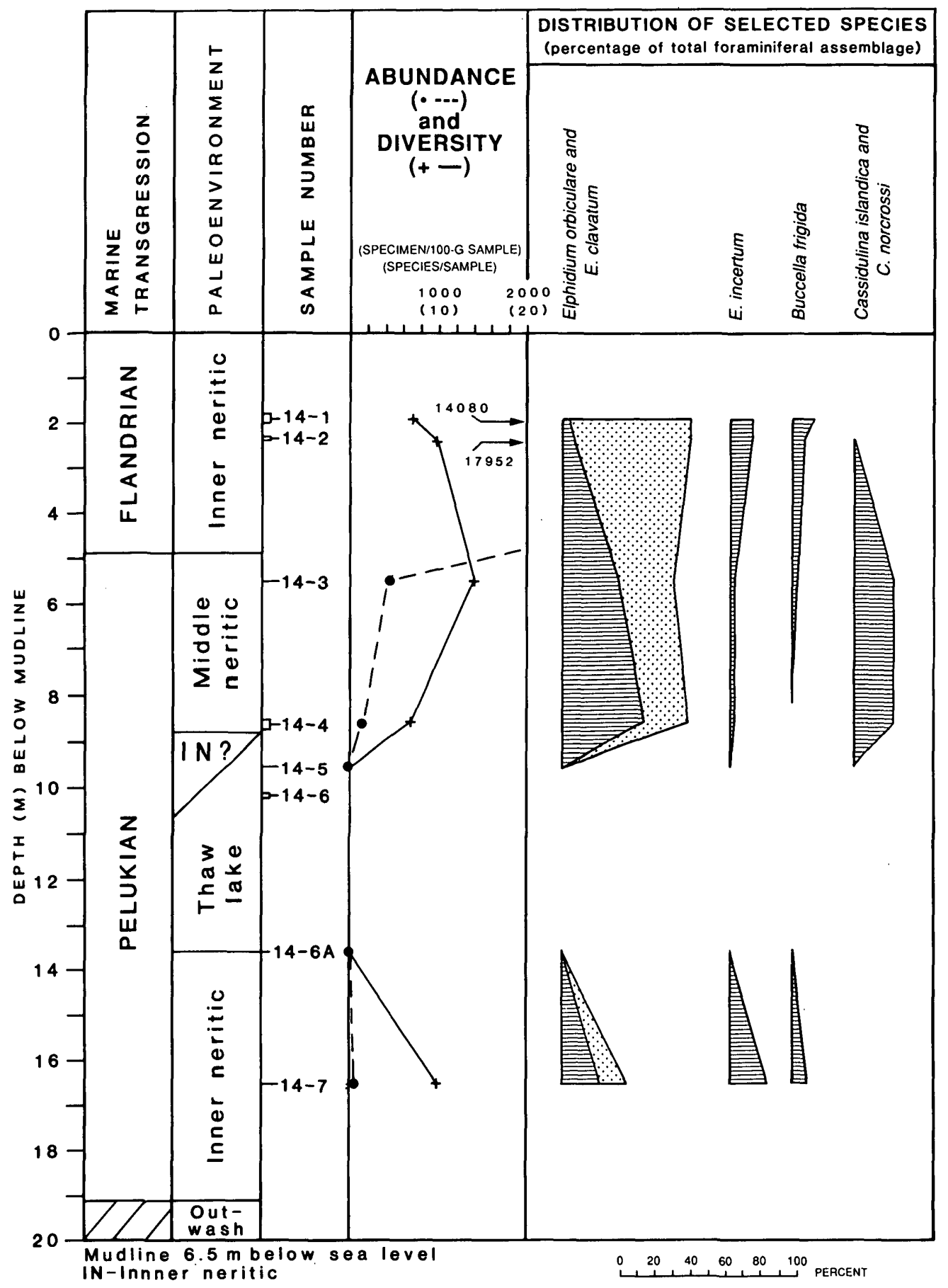

Figure 30. Benthic foraminiferal abundance (dot or number) and diversity (cross) and distribution of selective species in borehole HLA 14, Beaufort Sea shelf, Alaska. See table 13 for foraminiferal values. Transgressions summarized in figures 2 and 3. 
In Pelukian samples 14-4 and 14-3, foraminifers are common, and species diversity is low to moderate. Foraminiferal assemblages include abundant elphidiums, particularly E. clavatum (average 29\%) and E. orbiculare (average $38 \%$ ), abundant cassidulinids (22\%), and few Buccella frigida (average 1.6\%). This faunal composition suggests middle neritic water biofacies $(15-40 \mathrm{~m})$ with considerable downslope transport of shallow inner neritic material.

Flandrian faunas in samples 14-2 and 14-1 are characterized by abundant, low diversity foraminiferal assemblages. The foraminiferal assemblages are dominated by elphidiums (E. clavatum, 66\%); cassidulinids are absent. Abundant elphidiums (average 87\%) and common Buccella frigida (average $10 \%$ ) suggest that deposition occurred within the inner neritic biofacies with water depths of 10 to 20 meters and variable salinities. Abundant Elphidium incertum (average $12 \%$ ) indicate cold water and the possible presence of ice.

\section{BOREHOLE HLA 15 (Mf5731)}

Borehole HLA 15 was drilled $4.8 \mathrm{~km}$ east of Tigvariak Island and shoreward of the barrier island chain (fig. 1). Sedimentary units encountered in HLA 15 consist of (oldest to youngest) an unnamed sandy gravel unit, Newport sand unit, Shaviovik gravel unit, Maguire Islands unit, and Stefansson Sound unit (P.A. Smith, written commun., 1986; fig. 31). The oldest unit is composed of fine- to coarsegrained sand mixed with subrounded to subangular gravel and represents an early Pleistocene or older glacial outwash. This unit is not recognized in any other boreholes. Seismic reflector R4 (surface 4 of Wolf and others, 1985) is identified at $15.5 \mathrm{~m}$, a few meters above the base of the Maguire Islands unit in a layer of frozen sediments (fig. 31). A second seismic reflector $R$ ? is identified at $10.5 \mathrm{~m}$, at the same level as a lithologic change from gravel to sand. The basal Holocene seismic surface of Wolf and others $(1985,1956)$ is recognized at $6.7 \mathrm{~m}$ in the hole (R5) approximately at the boundary chosen on lithologic criteria for the base of the Stefansson Sound unit. Depths of stratigraphic units and seismic reflectors in the borehole follow.

HLA 15

\begin{tabular}{|c|c|c|}
\hline \multirow[t]{2}{*}{ Stratigraphic unit or seismic reflector } & \multicolumn{2}{|c|}{$\begin{array}{l}\text { Depth, in meters } \\
\text { below mudline }\end{array}$} \\
\hline & Top & Bottom \\
\hline Stefansson Sound unit ..................................... & 0.0 & 6.7 \\
\hline 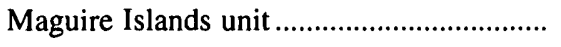 & 6.7 & 18.4 \\
\hline R5 & 6.7 & \\
\hline R? & 10.5 & \\
\hline R4 & 15.5 & \\
\hline Shaviovik gravel unit..... & 18.4 & 65.8 \\
\hline 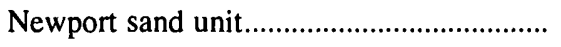 & 65.8 & 87.9 \\
\hline 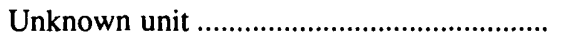 & 87.9 & 91.4 \\
\hline
\end{tabular}

Twelve microfossil samples were analyzed from borehole HLA 15. Samples 15-12 to 15-7 from the Newport sand unit are barren. Of the six samples in the upper part of the hole, sample 15-5 is barren and only ostracodes were recovered from sample 15-6. Benthic foraminifers and ostracodes were recovered from samples 15-4 to 15-1 (fig. 32, table 14). A late Pleistocene or older age is indicated for sample 15-6, whereas samples 15-4 to 15-1 are Holocene in age and represent the Flandrian transgression.

Sample 15-6 contains abundant nonmarine ostracodes including Candona rectangulata, Eucypris foveata, Ilyocypris bradii, Limnocythere liporeticulata, and L. platyforma. Ilyocypris bradii and $L$. liporeticulata dominate and suggest a pond or shallow lake, or a low-energy stream, and water temperatures of less than $20^{\circ} \mathrm{C}$. The minimum age of the sample is established by Eucypris foveata, which has not been found in sediments younger than 20,000 years B.P.; thus the age is no younger than late Pleistocene (E.M. Brouwers, written commun., 1982). The presence of seismic reflector R4 ( $15.5 \mathrm{~m})$ slightly below sample $15-6$ suggests that these deposits represent the Pelukian transgression.

Samples 15-4 to 15-1 represent the Flandrian transgression and contain abundant benthic foraminifers. Foraminiferal diversity and the amount of reworked material generally increase upsection. In samples 15-4 and 15-3, abundant elphidiums and common Buccella frigida (average 10\%) indicate that deposition occurred within the deeper inner neritic biofacies (10-20 m). In the upper samples (15-2 and 15-1), a decrease in the abundance of Buccella frigida, and increases in the abundance of Elphidium orbiculare and $E$. clavatum suggest a decrease in water depth $(0$ $10 \mathrm{~m}$ ) and a decrease in salinity. The upper benthic foraminiferal assemblages (15-2 and 15-1) also contain two agglutinated species, Reophax curtus and Trochamminella atlantica, and rare occurrences of Elphidium cf. E. asklundi, Cassidulina islandica, C. norcrossi, and Elphidiella groenlandica. The presence of agglutinated species is probably a response to an increase in organic matter and an increase in the silt-size particles. The calcareous species are believed to be reworked from older deposits.

\section{BOREHOLE HLA 16 (Mf5623)}

Borehole HLA 16 was drilled $4.8 \mathrm{~km}$ northwest of the west end of Alaska Island, seaward of the barrier island chain (fig. 1), and penetrated $33.5 \mathrm{~m}$ of sediment. Sedimentary units in HLA 16 consist of (oldest to youngest) Leffingwell Lagoon unit, Maguire Islands unit, Cross Island unit, and a Holocene lag deposit (P.A. Smith, written commun., 1986; fig. 33). Seismic reflector R3 (surface 3 of Wolf and others, 1985, 1986) is recognized at $29.8 \mathrm{~m}$, just above a 3.7-m-thick sequence of rounded to subangular gravel interpreted as beach deposits in the Leffingwell Lagoon unit. Seismic reflector R4 (surface 4 of Wolf and others, 1985), is identified at $17.8 \mathrm{~m}$ and coincides with the base of the Maguire Islands unit. Seismic reflector R5', near the base of the Cross Island unit, is not the basal Holocene reflector 


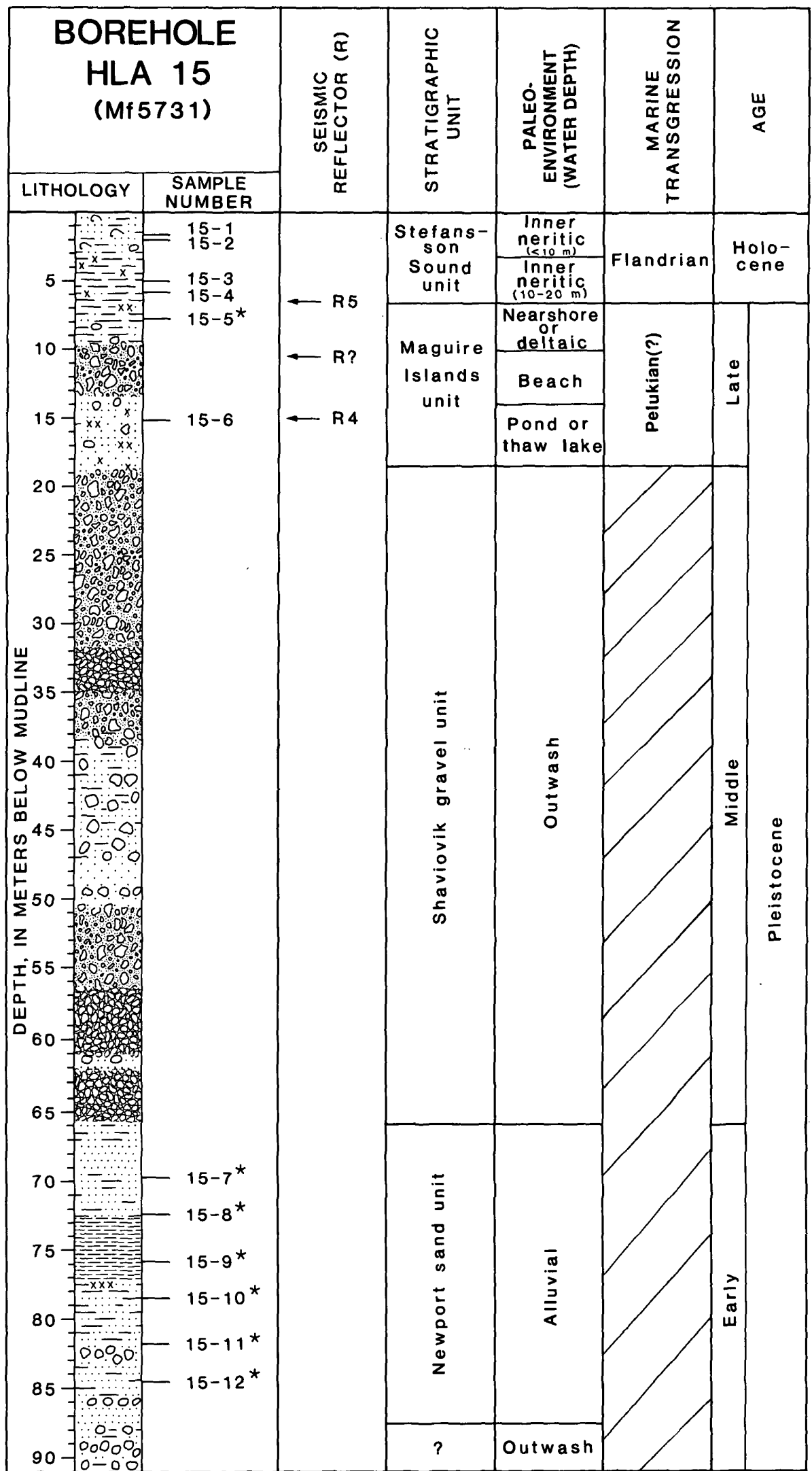

Mudline $5.5 \mathrm{~m}$ below sea level

* Barren of microfossils

Figure 31. Lithology, sample locations, lithostratigraphic units, paleoenvironments, and ages of borehole HLA 15, Beaufort Sea shelf, Alaska. Lithostratigraphic units and transgressions summarized in figures 4 and 5 and in figures 2 and 3, respectively. $R$, seismic reflector surface. 
identified by Wolf and others (1985). Reflector $\mathrm{R}^{\prime}$ is found at greater depths in most holes than the basal Holocene reflector and is seen primarily in the boreholes seaward of the barrier island chain. Depths of stratigraphic units and seismic reflectors in the borehole follow.

HLA 16

\begin{tabular}{|c|c|c|}
\hline \multirow{2}{*}{ Stratigraphic unit or seismic reflector } & \multicolumn{2}{|c|}{$\begin{array}{l}\text { Depth, in meters } \\
\text { below mudline }\end{array}$} \\
\hline & Top & Bottom \\
\hline Qf (Flandrian transgression) ........................... & 0.0 & $\overline{0.6}$ \\
\hline Cross Island unit & 6 & 1.2 \\
\hline R5' & 1.1 & \\
\hline 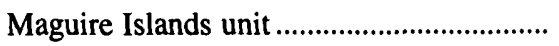 & 1.2 & 17.8 \\
\hline R4 & 17.8 & \\
\hline 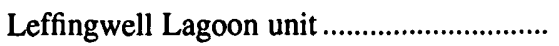 & 17.8 & 33.5 \\
\hline R3 & 29.8 & \\
\hline
\end{tabular}

Amino acid ratios (aIle/lle) based on benthic foraminifers were calculated for three samples from this borehole. The ratio of 0.085 for sample $16-11$ is within the range determined for the Wainwrightian transgression $(0.052-0.089)$ and somewhat greater than the average $(0.073)$ (Brigham, 1985b; P.A. Smith, written commun., 1986). The ratio of 0.051 to 0.054 for sample $16-10$ is somewhat less than the average for the Pelukian transgression $(0.066)$ but within the range of values for it $(0.053-0.078)$ (Brigham, 1985b; P.A. Smith, written commun., 1986). Assignment of these two samples to the Wainwrightian and Pelukian transgressions agrees with the lithologic and stratigraphic interpretations of these samples. The stratigraphic position and lithology of sample 16-1 suggest that this sample represents the Simpsonian transgression. An alle/lle ratio of 0.081 indicates, however, that specimens from the Wainwrightian or older transgressions were included in the analysis.

Twelve microfossil samples examined from borehole HLA 16 range in age from middle to late Pleistocene and represent the Wainwrightian, Pelukian, and Simpsonian transgressions (fig. 34, table 15). Foraminifers were recovered from all samples except 16-9, 16-7, and 16-6.

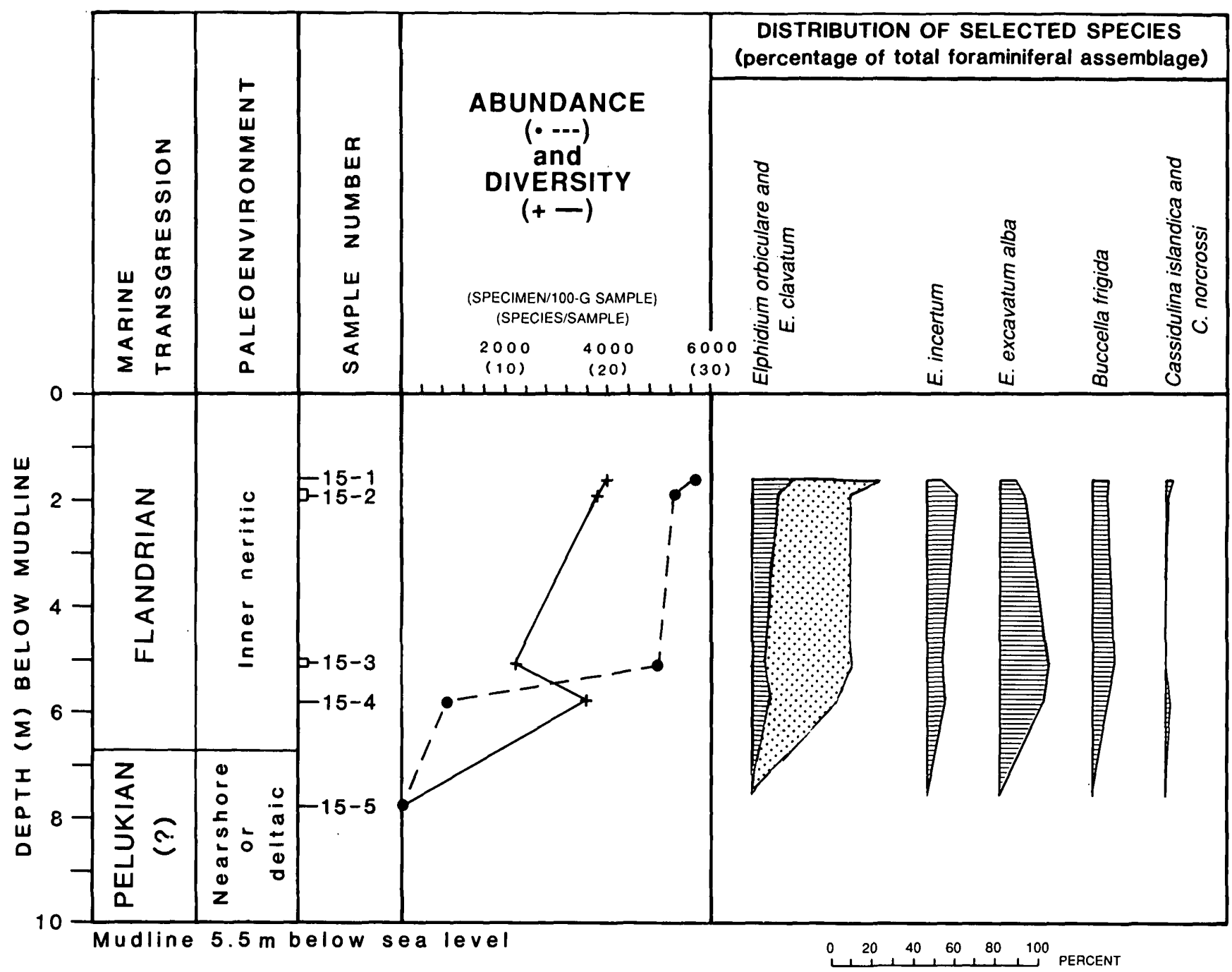

Figure 32. Benthic foraminiferal abundance (dot or number) and diversity (cross) and distribution of selective species in borehole HLA 15, Beaufort Sea shelf, Alaska. See table 14 for foraminiferal values. Transgressions summarized in figures 2 and 3. 
Faunas diagnostic of the Wainwrightian transgression (samples 16-11 and 16-12) include common to abundant and diverse foraminifers. These assemblages indicate middle neritic water biofacies and include several species associated with Atlantic water masses. In the older foraminiferal assemblage, abundant cassidulinids (23\%), Buccella frigida (20\%), and rare Stainforthia concava and Bolivina pseudopunctata suggest that deposition occurred in the middle neritic

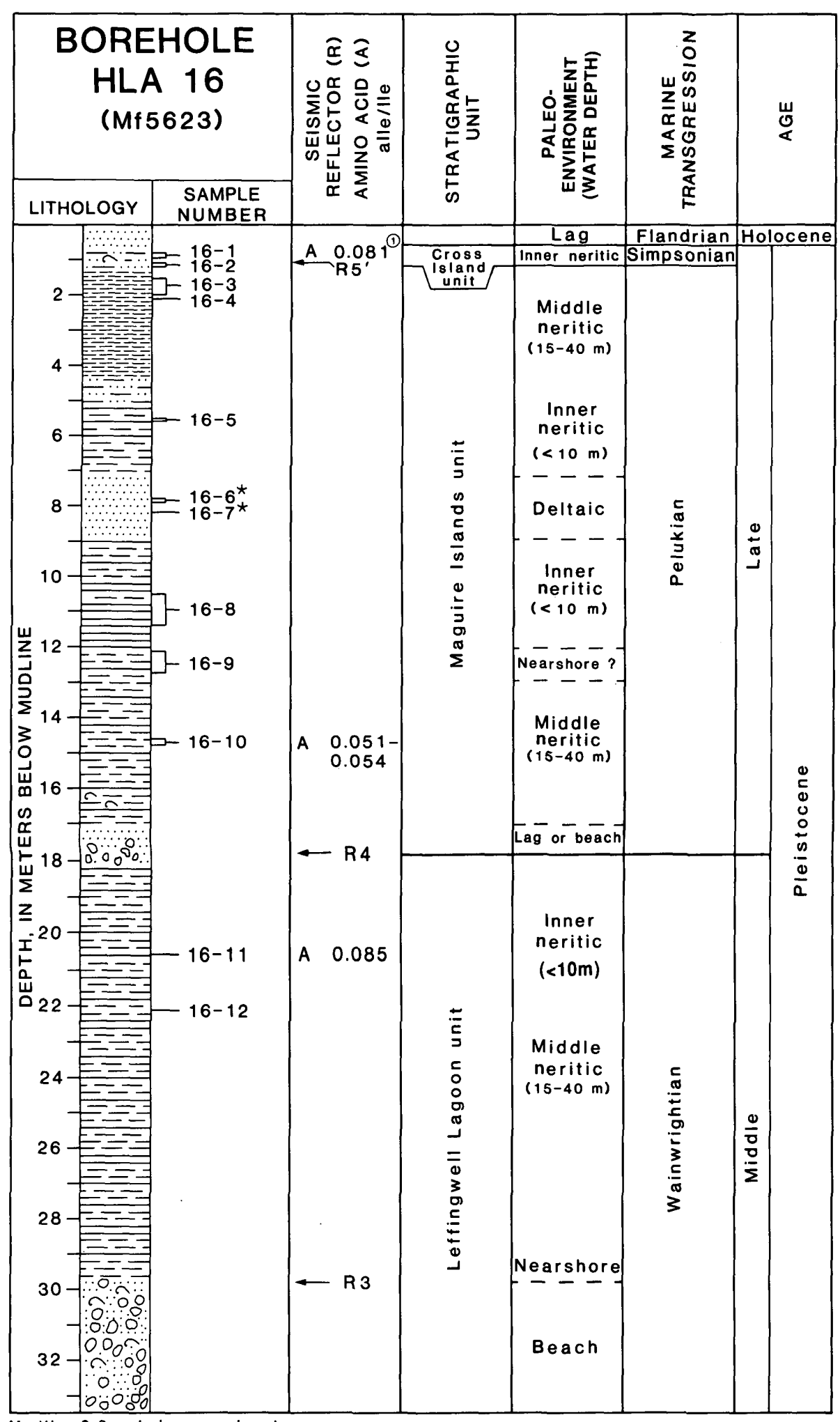

Mudline $9.2 \mathrm{~m}$ below sea level

* Barren of microfossils

(1) Sample contaminated by older material
Figure 33. Lithology, sample locations, lithostratigraphic units, paleoenvironments, and ages of borehole HLA 16, Beaufort Sea shelf, Alaska. Paleoenvironment contacts dashed where approximate. Lithostratigraphic units and transgressions summarized in figures 4 and 5 and in figures 2 and 3, respectively. $\mathrm{R}$, seismic reflector surface. 
Figure 34. Benthic foraminiferal abundance (dot or number) and diversity (cross) and distribution of selective species in borehole HLA 16, Beaufort Sea shelf, Alaska. See table 15 for foraminiferal values. Paleoenvironment contacts dashed where approximate. Transgressions summarized in figures 2 and 3.

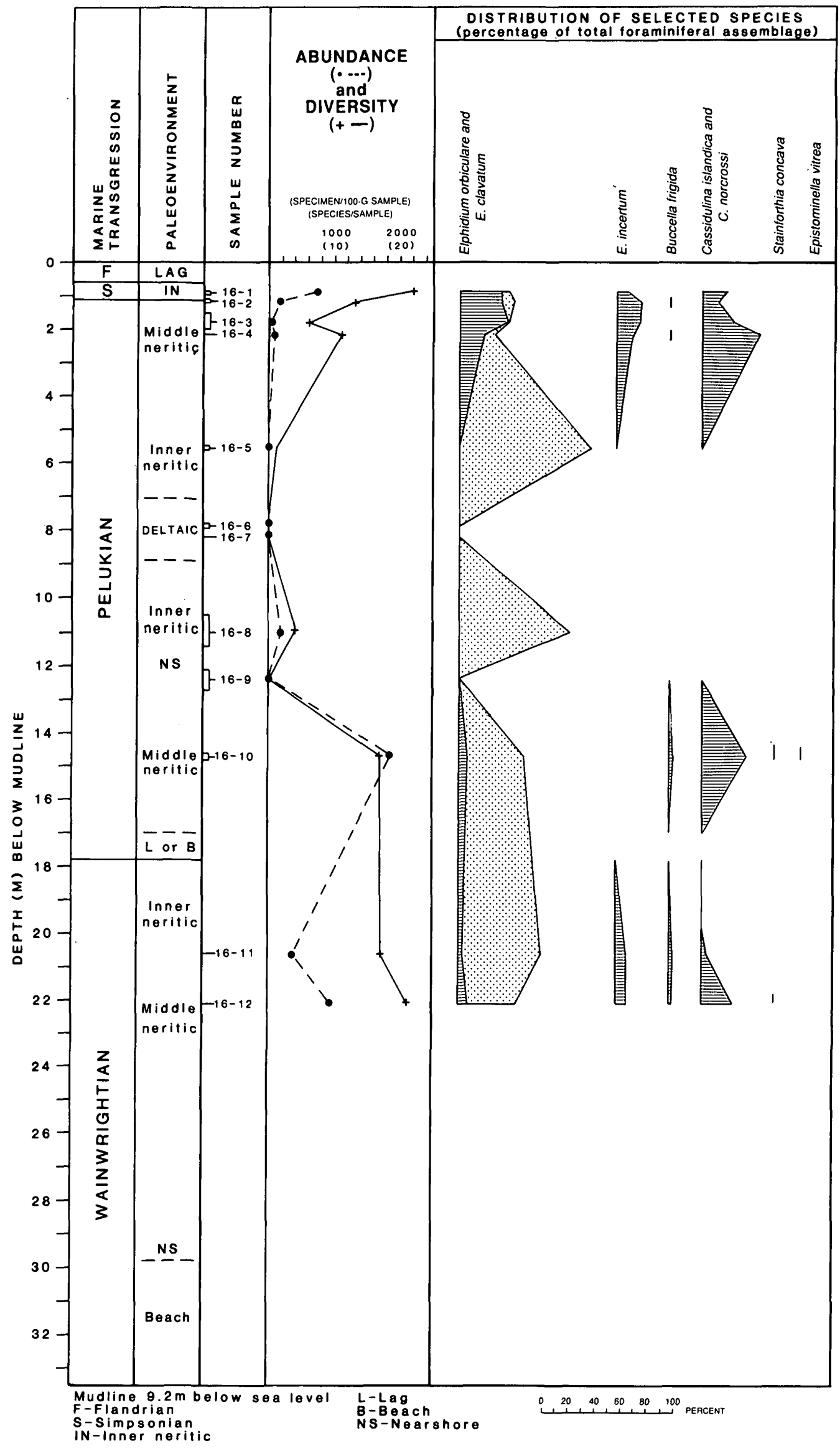


biofacies $(15-40 \mathrm{~m})$. The presence of Gordiospira arctica and Bolivina pseudopunctata in this interval indicates the influx of warmer Atlantic waters. In sample 16-11, the abundance of elphidiums and the decline or absence of middle neritic species indicates a decrease in water depth to probably shallow inner neritic depths $(0-10 \mathrm{~m})$. The slight increase of Elphidium incertum suggests that water temperatures have may been declining also.

The oldest Pelukian sample, 16-10, overlies beach gravels and contains abundant benthic foraminifers. Although elphidiums dominate the foraminiferal assemblages, abundant cassidulinids (34\%) and a few outer neritic species (Epistominella vitrea and Stainforthia concava) suggest that deposition occurred at middle neritic $(15-40 \mathrm{~m})$ or possibly outer neritic (35-200 m) biofacies. The rare Epistominella vitrea $(<1 \%)$ indicates the presence of the warmer Atlantic water mass, which is presently found at depths of $200 \mathrm{~m}$ and more (Lagoe, 1979). Eggerella advena $(<1 \%)$, which also appears in sample 16-10, characterizes the warmer Bering Sea Water mass and is currently found at depths of 40 to $60 \mathrm{~m}$ on the Beaufort Sea shelf (R.J. Echols, written commun., 1978). These warmer water species suggest that deposition may have occurred at outer neritic depths under the influence of the warmer water masses. These species are rare, so deposition in the deeper part of the middle neritic biofacies is believed to be most probable.

Foraminifers are scarce in samples 16-8 and 16-5 and absent in samples 16-9, 16-7 and 16-6. Deltaic and nearshore conditions that may have prevailed during deposition of the interval from 12.7 to $5.6 \mathrm{~m}$ (P.A. Smith, written commun., 1986) would account for the sparsely fossiliferous to barren samples. Low specimen numbers and low diversity characterize the foraminiferal assemblages in samples 16-8 and 16-5. Elphidiums (E. clavatum), which dominate these assemblages, suggest that deposition occurred at water depths of less than $10 \mathrm{~m}$ and in lower salinities. Sparse ostracode assemblages in samples 16-9, 16-8, and 16-5 suggest shallow water depths and cold, seasonally fluctuating temperatures (E.M. Brouwers, written commun., 1985).

Samples 16-4 and 16-3 are indicative of the latest phase of the Pelukian transgression, when water depths and temperatures were decreasing. Foraminifers are not abundant, and diversity is low (average 9). The elphidiums (average $56 \%$ ), Cassidulina norcrossi (average 33\%), and rare Buccella frigida suggest that deposition occurred in the middle neritic biofacies $(15-40 \mathrm{~m})$. Elphidium incertum (average $14 \%$ ) suggests that water temperatures were cold. Elphidiella groenlandica indicate that considerable transport or reworking has occurred.

The foraminiferal assemblage in sample 16-2, from a silty sand at approximately the same depth as seismic reflector $\mathrm{R}^{\prime}(1.1 \mathrm{~m})$, is a mixture of Pelukian and Simpsonian faunas. Elphidium incertum and $E$. orbiculare continue at the same abundance, cassidulinids decrease, and rare E. albiumbilicatum appears in sample 16-2. The abundant elphidiums and few cassidulinids suggest that deposition occurred in cold, shallow water $(0-20 \mathrm{~m})$. Elphidium albiumbilicatum, present in this sample, is often associated with increasing temperatures and an influx of warmer, low-salinity water (Knudsen, 1978; Guilbault, 1980). Mixing of faunas from the Pelukian and Simpsonian transgressions explains the presence of those species characteristic of cold conditions and those characteristic of warming conditions.

Sample 16-1, taken from the silty sand $0.2 \mathrm{~m}$ above sample 16-2, is interpreted as representing the Simpsonian transgression. An abundant and diverse foraminiferal assemblage is present. An increase in shallower water species and the appearance of quinqueloculinids and Elphidium bartletti indicate that deposition occurred at 15 to $20 \mathrm{~m}$, where these species are common. The few E. albiumbilicatum and rare $E$. frigidum indicate warming conditions and the influx of warmer low-salinity water, probably from local rivers. Elements of this fauna may be reworked. The stratigraphic position and lithology of sample 16-1 suggest that this sample represents the Simpsonian transgression; however, the alle/lle ratio of 0.081 for sample $16-1$ indicates that the Simpsonian assemblage here includes reworked Wainwrightian or older material. The presence of common cassidulinids and few Elphidiella groenlandica and Elphidium asklundi may be faunal evidence of reworking.

\section{BOREHOLE HLA 17 (Mf5624)}

Borehole HLA 17 was drilled $6.4 \mathrm{~km}$ north of the eastern end of Alaska Island, seaward of the barrier island chain (fig. 1). Sedimentary units recognized in borehole HLA 17 consist of (oldest to youngest) Leffingwell Lagoon unit, Maguire Islands unit, Cross Island unit, and a Holocene lag deposit (P.A. Smith, written commun., 1986; fig. 35). A strong seismic reflector R3 (surface 3 of Wolf and others, 1985), which marks the base of the Leffingwell Lagoon unit, is present at $48 \mathrm{~m}$ below sea level, nearly $2 \mathrm{~m}$ below the bottom of the hole. Seismic reflector R4 (surface 4 of Wolf and others, 1985) is recognized at $17.0 \mathrm{~m}$ in the hole, above the sands and gravels that mark the base of the Maguire Islands unit and the base of the Pelukian transgression in this borehole. Seismic reflector R5', at $2.5 \mathrm{~m}$ in the hole, is below the Cross Island unit and the base of Simpsonian transgression at $1.2 \mathrm{~m}$. Depths of stratigraphic units and seismic reflectors in the borehole follow.

HLA 17

\begin{tabular}{|c|c|c|}
\hline \multirow{2}{*}{ Stratigraphic unit or seismic reflector } & \multicolumn{2}{|c|}{$\begin{array}{l}\text { Depth, in meters } \\
\text { below mudline }\end{array}$} \\
\hline & Top & Bottom \\
\hline Qf (Flandrian transgression) ............................. & 0.0 & 0.4 \\
\hline Cross Island unit & .4 & 1.2 \\
\hline Maguire Islands unit & 1.2 & 21.6 \\
\hline $\mathrm{R5}^{\prime} \ldots \ldots \ldots \ldots \ldots$ & 2.5 & \\
\hline R4 ........ & 17.0 & \\
\hline Leffingwell Lagoon unit................................ & 21.6 & 31.6 \\
\hline
\end{tabular}


Benthic foraminifers are present in all 20 samples analyzed from borehole HLA 17 (fig. 36, table 16). Three foraminiferal assemblages are recognized and correspond to the Wainwrightian, Pelukian, and Simpsonian transgressions.

The oldest Wainwrightian foraminiferal assemblage (sample 17-20) is dominated by Elphidium clavatum and contains abundant $E$. incertum as well as other Elphidium species,
Quinqueloculina seminulum, and two agglutinated species. This association indicates that deposition occurred during the initial phases of the transgression when the waters were cool, of low salinity, and shallow $(0-10 \mathrm{~m})$. In the overlying sample 17-19 elphidiums decrease in abundance while cassidulinids (31\%) and Buccella frigida (4\%) increase. A few middle and outer neritic species, such as Stainforthia
Figure 35. Lithology, sample locations, lithostratigraphic units, paleoenvironments, and ages of borehole HLA 17, Beaufort Sea shelf, Alaska. Paleoenvironment contacts dashed where approximate. Lithostratigraphic units and transgressions summarized in figures 4 and 5 and in figures 2 and 3 , respectively. $R$, seismic reflector surface.

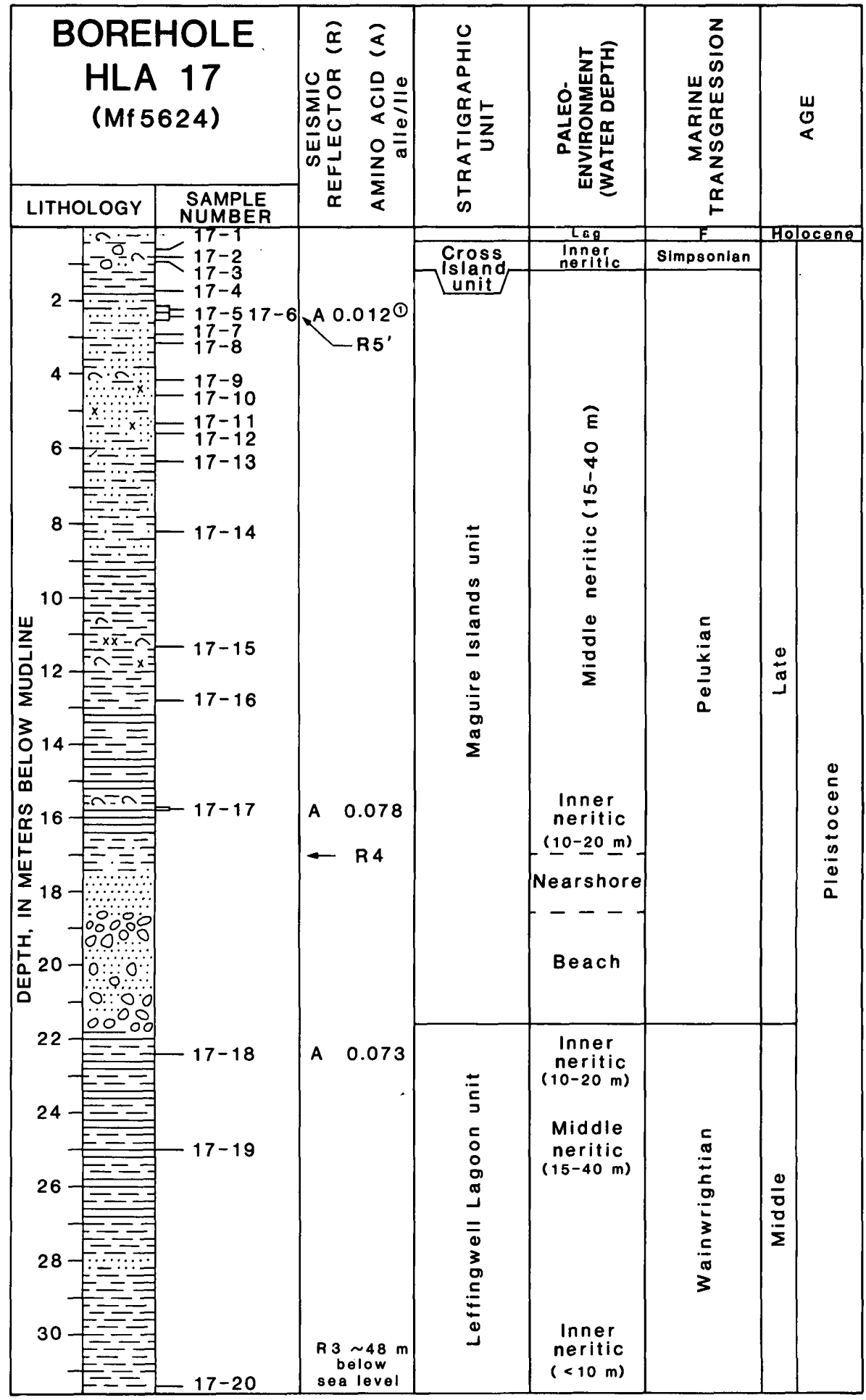

Mudline $14.5 \mathrm{~m}$ below sea level

(1) Sample contaminated by older materia

F - Flandrian 


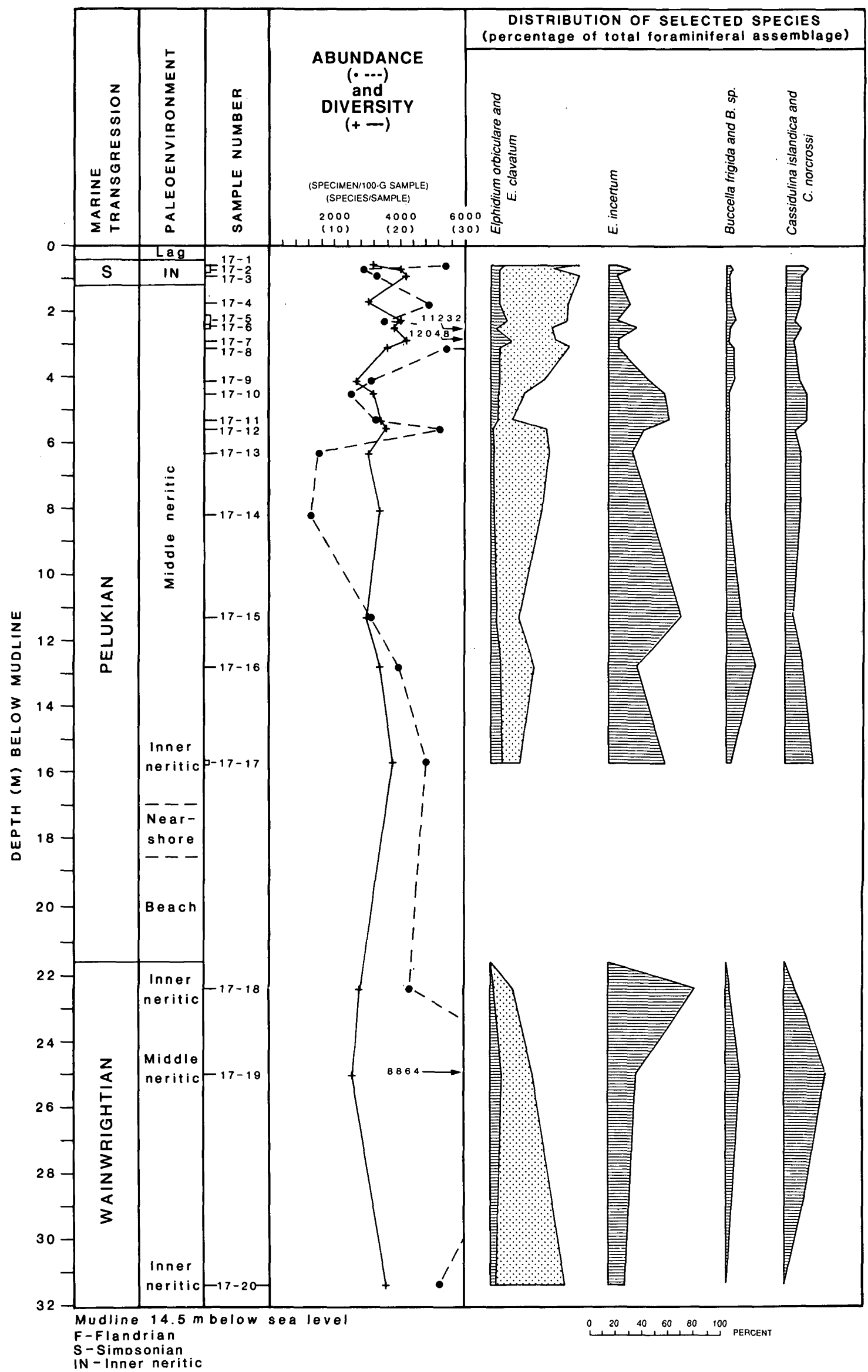


concava and Cassidulina norcrossi, appear. This assemblage indicates that water depths had increased, and deposition was occurring in the middle neritic biofacies $(15-40 \mathrm{~m})$. Cool temperatures are suggested by the increased abundance of Elphidium incertum (21\%). The youngest sample in the Wainwrightian interval, 17-18, suggests that water depths had decreased because the abundance of middle and outer neritic species declines, cassidulinids decrease to 10 percent, and elphidiums increase to 84 percent. Cold temperatures and lower salinity waters are indicated by the dominance of $E$. incertum (65\%). Although Buccella frigida is not abundant $(1 \%)$, the assemblage suggests deep inner neritic conditions (10-20 m).

The Pelukian foraminiferal assemblages (samples 17-17 to 17-4) are from sediments above beach and nearshore sands between 21.6 and $17.0 \mathrm{~m}$ that are assigned to the Pelukian transgression. The foraminiferal assemblages are abundant (average 4,710 specimens) and diverse (average 17 species). Although the assemblages are dominated by elphidiums, Buccella frigida (average $4 \%$ ) and cassidulinids (average $11 \%$ ) appear in sufficiently high numbers to indicate that deposition occurred in the deeper inner neritic to middle neritic biofacies (10-20 to $15-40 \mathrm{~m})$ and that the shallow inner neritic species are transported. Outer neritic species are rare, occurring only in sample 17-16. Abundant Elphidium incertum in samples 17-17 to 17-10, indicate cool temperatures and the probable presence of ice. The dominance of Elphidium clavatum in samples 17-9 to 17-4 indicates a slight increase in water temperatures. Warmer conditions are also suggested by an overall increase in the abundance of Elphidium excavatum alba in samples 17-8 to 17-5. Elphidiums and other shallow inner neritic species that are more abundant in the upper samples 17-14 to 17-4 suggest a decrease in water depth upsection. This proposed decrease in water depth also corresponds to an increase in sand beginning at $9 \mathrm{~m}$. Sediments between 9 and $1.2 \mathrm{~m}$ have been interpreted as deltaic (P.A. Smith, written commun., 1986). The occurrence of Elphidium albiumbilicatum in samples 17-14 to 17-5, with greater abundances in samples 17-12, 17-9, 17-7 and 17-6, suggests an influx of lower salinity water, possibly from rivers.

Faunal assemblages in samples 17-3 to 17-1 represent the Simpsonian transgression. The diverse foraminiferal assemblages, which are dominated by elphidiums and contain abundant cassidulinids (average 13.5\%) and few Buccella frigida (average $<4 \%$ ), suggest that deposition occurred in the deep inner neritic biofacies. Common $\mathrm{El}$ phidium incertum (average 10\%) indicate cooler waters.

Figure 36. Benthic foraminiferal abundance (dot or number) and diversity (cross) and distribution of selective species in borehole HLA 17, Beaufort Sea shelf, Alaska. See table 16 for foraminiferal values. Paleoenvironment contacts dashed where approximate. Transgressions summarized in figures 2 and 3 .
The abundance of the various species, which is similar to the underlying Pelukian interval, suggests a similar environment. These benthic foraminifers have no anomalously high or low abundance values or different preservational states that would suggest reworked older material.

\section{BOREHOLE HLA 18 (Mf5625)}

Borehole HLA 18 was drilled $1.6 \mathrm{~km}$ north of Flaxman Island in the eastern end of the study area and seaward of the barrier island chain (fig. 1). Nine sedimentary units are recognized in borehole (fig. 37). The Camden Bay unit, Brunlow Point unit, and North Star sand unit were recognized only in this borehole, whereas the younger Staines River unit, Duchess sand unit, Leffingwell Lagoon unit, Maguire Islands unit, and Cross Island unit are also recognized in other boreholes (P.A. Smith, written commun., 1986). A Holocene lag deposit is also present in HLA 18. Seismic reflector R3 (surface R3 of Wolf and others, 1985) is recognized at $29.4 \mathrm{~m}$, above the base of the Leffingwell Lagoon unit, and seismic reflector R4 (surface 4 of Wolf and others, 1985) is at $16.7 \mathrm{~m}$, just above the slightly coarser basal sediments of the Maguire Islands unit. Seismic reflector $\mathrm{R}^{\prime}$ is between the thinly laminated clayey silts of the upper part of the Maguire Islands unit and the silty organic-rich sand of the Cross Island unit (fig. 37). Depths of stratigraphic units and seismic reflectors in the borehole follow.

HLA 18

\begin{tabular}{|c|c|c|}
\hline \multirow[t]{2}{*}{ Stratigraphic unit or seismic reflector } & \multicolumn{2}{|c|}{$\begin{array}{l}\text { Depth, in meters } \\
\text { below mudline }\end{array}$} \\
\hline & Top & Bottom \\
\hline Qf (Flandrian transgression) ......................... & 0.0 & 0.7 \\
\hline 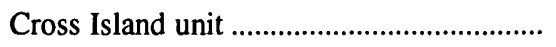 & .7 & 2.1 \\
\hline $\mathrm{RS}^{\prime}$ & 2.1 & \\
\hline 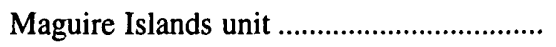 & 2.1 & 18.9 \\
\hline R4 & 16.7 & \\
\hline 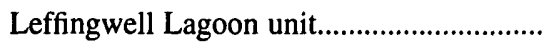 & 18.9 & 30.2 \\
\hline $\mathrm{R} 3$ & 29.4 & \\
\hline Duchess sand unit ............. & 30.2 & 37.0 \\
\hline 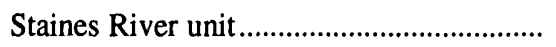 & 37.0 & 58.7 \\
\hline 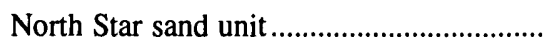 & 58.7 & 76.7 \\
\hline 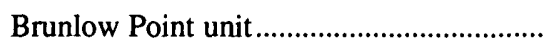 & 76.7 & 91.5 \\
\hline 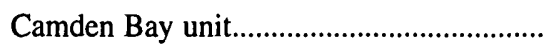 & 91.5 & 92.4 \\
\hline
\end{tabular}

Seven transgressive marine sequences are recognized in microfossil assemblages of HLA 18 and range in age from late Pliocene to Holocene: Beringian; Anvillian; Fishcreekian; Wainwrightian; Pelukian; Simpsonian; and Flandrian (fig. 38, table 17). Samples 18-36, 18-33, 18-32, $18-12,18-11$, and 18-6 are barren, and samples $18-17$ and 18-7 contain some ostracodes but no foraminifers. These 


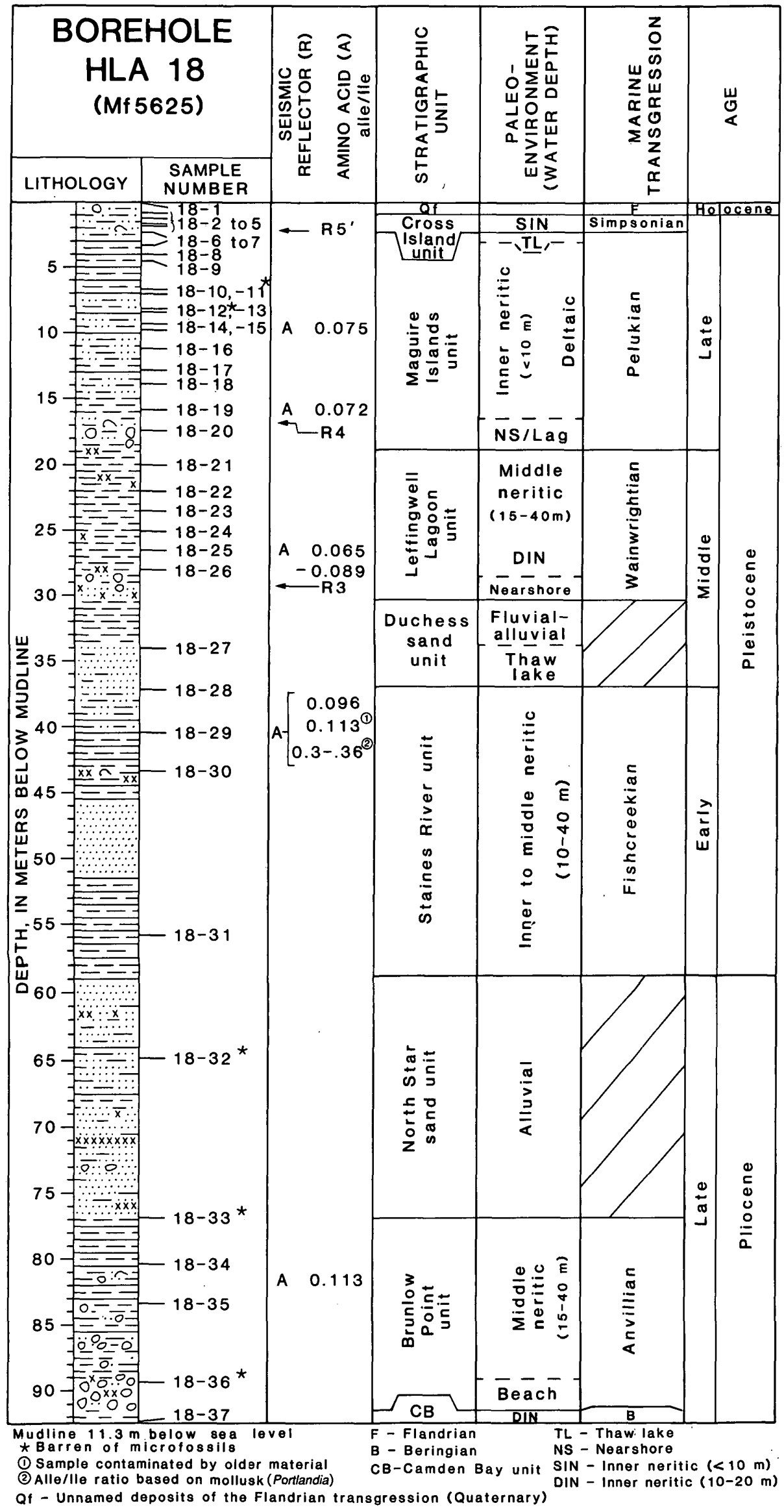

Figure 37. Lithology, sample locations, lithostratigraphic units, paleoenvironments, and ages of borehole HLA 18, Beaufort Sea shelf, Alaska. Paleoenvironment contacts dashed where approximate. Lithostratigraphic units and transgressions summarized in figures 4 and 5 and in figures 2 and 3, respectively. $R$, seismic reflector surface.
Figure 38. Benthic foraminiferal abundance (dot or number) and diversity (cross) and distribution of selective species in borehole HLA 18, Beaufort Sea shelf, Alaska. See table 17 for foraminiferal values. Paleoenvironment contacts dashed where approximate. Transgressions summarized in figures 2 and 3 . 


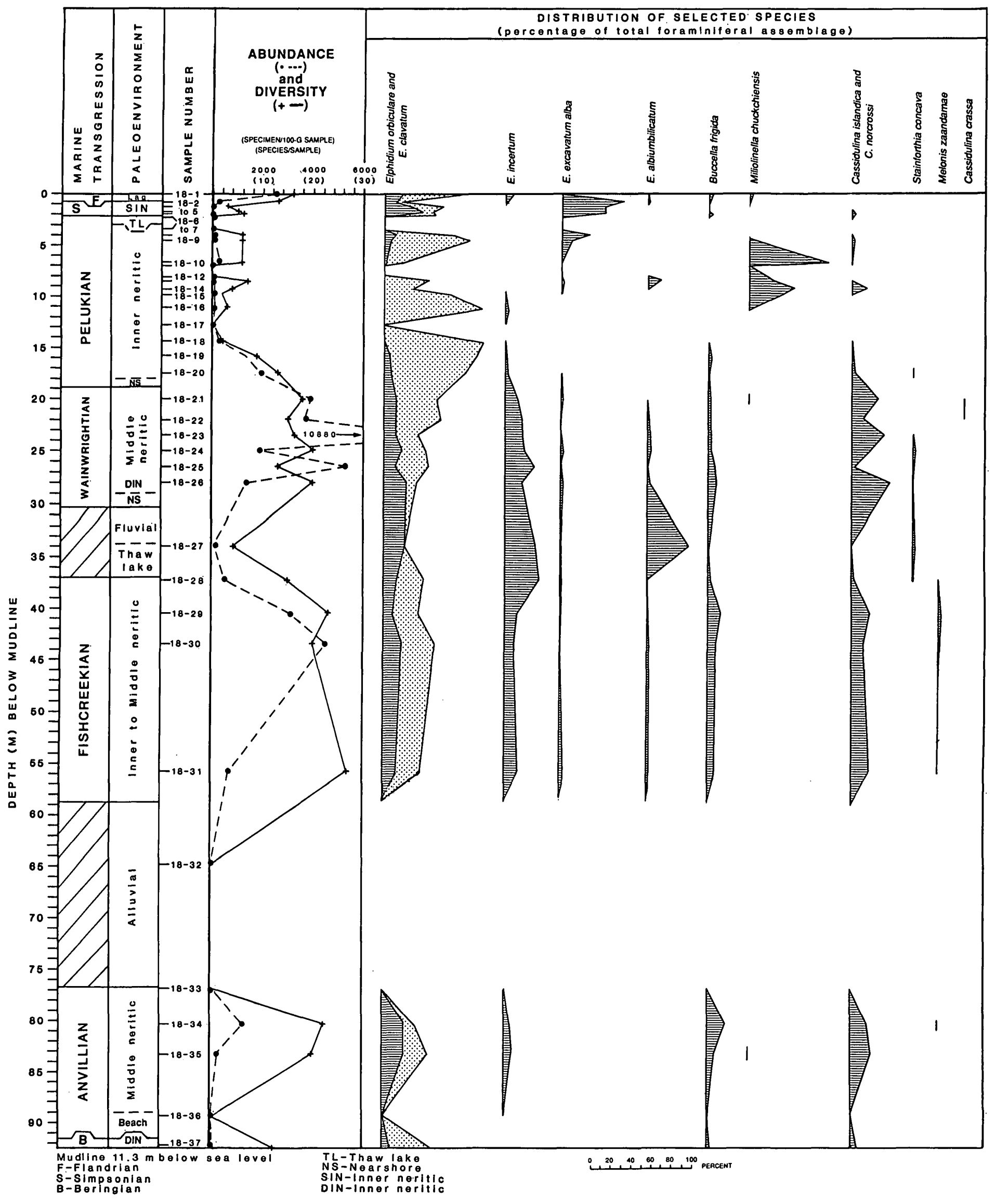


samples may represent nonmarine or very shallow marine deposits.

The Beringian sample, 18-37, includes common and diverse foraminifers. The abundance of the elphidiums (48\%), Buccella frigida and B. inusitata (4\%), and cassidulinids $(5 \%)$ suggests that deposition occurred in the deep inner neritic biofacies $(10-20 \mathrm{~m})$. The abundance of Quinqueloculina seminulum $(35 \%)$ and Scutuloris tegminis (1\%) indicates that deposition occurred in the deeper part of this biofacies where the water is turbid and has less organic material.

The Anvillian faunas, samples $18-35$ and 18-34, include a diverse and common to abundant foraminiferal assemblage. Elphidiums are abundant, and Buccella frigida (average $11 \%$ ) and cassidulinids (average $18 \%$ ) are common. Together these faunal characteristics indicate that deposition occurred no shallower than the deep inner neritic biofacies $(10-20 \mathrm{~m})$ and probably within the middle neritic biofacies $(15-40 \mathrm{~m})$. Common polymorphinids and lagenids indicate calm, less turbulent waters. A rare outer neritic species, Melonis zaandamae, appears in sample 18-34. This species may be reworked from older sediments but probably represents the in situ fauna as this form has been found at shallow shelf depths in finegrained organic sediments associated with winnowing and more intense current regimes (Jansen and others, 1983; Osterman and Nelson, 1989).

Two age-diagnostic species appear in the Anvillian assemblages, Elphidiella? brunnescens and Elphidium ustulatum. Several specimens identified as Elphidiella? brunnescens in samples 18-35 and 18-34 are probably reworked. This species has been recognized in the Nuwok Member of the Sagavanirktok Formation southeast of the study area along Carter Creek (Todd,1957). The Nuwok has subsequenty been interpreted as late Oligocene in age (McNeil and Miller, 1990), in the Oligocene to Miocene Cibicidoides Assemblage Zone of the Beaufort-Mackenzie Basin in western Arctic Canada (McNeil, 1989). Younger occurrences of this species are unknown, thus its presence in borehole HLA 18 is assumed to indicate reworking of older sediments. Elphidium ustulatum was originally identified from the Nuwok Member along Carter Creek (Todd, 1957). The range of this species is now recognized as late Pliocene to Pleistocene, and it is most abundant in latest Pliocene to earliest Pleistocene (1.8-0.8 Ma) sediments throughout the circum-Arctic region and North Sea (Feyling-Hanssen, 1985; Young and McNeil, 1984; McNeil, 1989). Elphidium ustulatum is present in the Beringian and Anvillian assemblages of borehole HLA 18 and common in the Fishcreekian assemblages (table 17). The Anvillian assemblages in borehole HLA 18 are therefore considered late Pliocene in age. The Anvillian faunas are separated from the overlying Fishcreekian faunas by an interval of fine- to coarse-grained sand and peat (76.7-58.7 $\mathrm{m})$. Abundant plant material and the absence of foramini- fers or ostracodes in samples 18-33 and 18-32 from the sand and peat interval suggest nonmarine conditions.

Foraminiferal assemblages assigned to the Fishcreekian transgression (samples 18-31 to 18-28) are abundant and highly diverse. These assemblages indicate that deposition probably occurred in the deep inner neritic to middle neritic biofacies (15-40 m). Elphidiums (average 70\%) dominate the assemblages, which also contain moderate percentages of Buccella frigida (average 7\%) and cassidulinids (average 12\%). Rare Melonis zaandamae, an outer neritic species, suggests either that deposition occurred in the deeper part of the middle neritic biofacies or that a cooler water mass was present in the middle shelf. Deep inner neritic and middle neritic species decrease slightly in abundance in sample 18-28, implying a slight decrease in water depth. Common Elphidium incertum (average 17\%) suggest that cooler, less saline waters and ice were present throughout the Fishcreekian transgression. Amino acid ratios based on the foraminifer Elphidium clavatum from the Fishcreekian samples yield ratios between 0.096 and 0.113 . The smaller ratios result when only well-preserved specimens of $E$. clavatum are analyzed, whereas the higher ratios result when specimens are randomly chosen. The higher ratios are believed to indicate contamination of the Fishcreekian assemblages by Anvillian, Beringian, or older specimens of $E$. clavatum. The abundance and diversity of the Fishcreekian faunas may reflect the reworking of many older specimens.

The age of the Fishcreekian samples is suggested by the presence of common Elphidium ustulatum, which is most common in circum-Arctic sediments between 1.8 and 0.8 Ma (Feyling-Hanssen, 1985; Young and McNeil, 1984; McNeil, 1989). The early Pleistocene age suggested for the Fishcreekian transgression is compatible with this age range.

Five benthic foraminifers and moderately abundant ostracodes are present in sample 18-27. The foraminiferal assemblage is composed entirely of elphidiums and indicates cold, shallow water and low salinity. This assemblage may represent the in situ fauna or may be reworked from the underlying Fishcreekian faunas. The ostracode assemblage is composed entirely of nonmarine species that suggest a fresh-water environment (E.M. Brouwers, written commun., 1982).

Wainwrightian faunas include abundant and diverse foraminiferal assemblages. Abundance fluctuates considerably in this interval (samples 18-26 to 18-21) and peaks in samples $18-25$ and 18-23. Because the abundance in sample 18-25 results from the presence of similar-sized shallowwater species, it is probably related to downslope transport. The abundance in sample 18-23 appears to be related to an increase in middle neritic specimens, which probably represent a period of less intense current movement.

Wainwrightian foraminiferal assemblages contain abundant elphidiums, abundant cassidulinids (averaging 21\%), 
and usually few Buccella frigida ( $\leq 6 \%)$. This composition suggests middle neritic biofacies $(15-40 \mathrm{~m})$. Although representing less than 3 percent of the assemblage, the outer neritic species Stainforthia concava and the upper bathyal species Cassidulina crassa suggest a deeper middle neritic biofacies. The persistent occurrence of Elphidium incertum (average 18\%) throughout this interval indicates that the surface water mass was cold and ice was present.

In most of the Pelukian samples (18-20 to 18-6), foraminifers are few to rare and diversity is low. Samples 18-12 and 18-11 are barren, and sample 18-17 contains only ostracodes. The abundance of elphidiums, particularly $E$. clavatum, throughout most of the Pelukian suggests that water depths were probably less than $10 \mathrm{~m}$. The abundance of $E$. albiumbilicatum in sample 18-13 suggests an influx of low-salinity water, which usually accompanies warmer temperatures. Samples 18-20 and 18-19 contain abundant and moderately diverse foraminiferal assemblages. These samples are just above the sediment identified as a lag deposit, and considerable reworking of the underlying Wainwrightian faunas is probable. Elphidium clavatum dominates and probably represents the in situ fauna. Sediments in this interval are believed to represent deltaic deposition (P.A. Smith, written commun., 1986).

Samples 18-7 and 18-6 may be part of the Pelukian transgression. Sample 18-7 contains only two ostracode specimens, and 18-6 is barren (E.M. Brouwers, written commun., 1982). Both samples contain abundant plant fragments and could represent thaw-lake deposits.

In the four Simpsonian samples (18-5 to 18-2), foraminifers are rare to common and the diversity is generally low. The elphidiums, which dominate, indicate that deposition occurred in the shallow inner neritic biofacies (0-10 $\mathrm{m}$ ) having lower or variable salinities and cool water temperatures. Sample 18-5 contains several specimens that are probably reworked from older material. Sample 18-2 contains a moderately abundant foraminiferal assemblage that suggests slightly deeper water depths.

The Flandrian transgression is represented by sample 18-1. The abundant and moderately diverse foraminiferal assemblage is characterized by abundant and diverse elphidiums; Elphidium clavatum (56\%) and E. orbiculare (17\%) dominate. The few specimens of Quinqueloculina seminulum indicate turbid waters.

\section{BOREHOLE HLA 19 (Mf5729)}

Borehole HLA 19 was drilled $3.2 \mathrm{~km}$ north of Pole Island, seaward of the barrier island chain (fig. 1). Sedimentary units in borehole HLA 19 consist of (oldest to youngest) Duchess sand unit, Leffingwell Lagoon unit, Maguire Islands unit, and Mikkelsen Bay unit (P.A. Smith, written commun., 1985; fig. 39). A Holocene lag deposit is present at the top of the hole. Seismic reflectors R3 and
R4 (surfaces 3 and 4 of Wolf and others, 1985), are recognized in HLA 19. Seismic reflector R3, just below the change to clayey silt at $29.4 \mathrm{~m}$, coincides with the boundary between the Duchess sand and Leffingwell Lagoon units. Seismic reflector R4 coincides with the boundary between the Leffingwell Lagoon and Maguire Islands units at the change from clay to silt at $16.5 \mathrm{~m}$. Depths of stratigraphic units and seismic reflectors in the borehole follow.

HLA 19

\begin{tabular}{|c|c|c|}
\hline \multirow{2}{*}{ Stratigraphic unit or seismic reflector } & \multicolumn{2}{|c|}{$\begin{array}{l}\text { Depth, in meters } \\
\text { below mudline }\end{array}$} \\
\hline & Top & Bottom \\
\hline 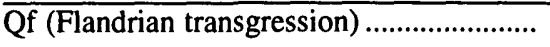 & 0.0 & 0.6 \\
\hline 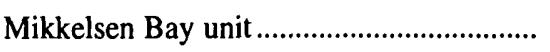 & .6 & 11.6 \\
\hline 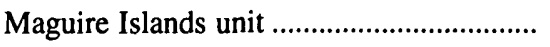 & 11.6 & 16.5 \\
\hline R4 & 16.5 & \\
\hline 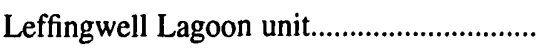 & 16.5 & 29.5 \\
\hline R3 & 29.4 & \\
\hline 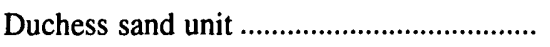 & 29.5 & 35.5 \\
\hline
\end{tabular}

Nineteen samples ranging in age from middle Pleistocene to Holocene were examined for microfossils from borehole HLA 19. Benthic foraminiferal faunas are characteristic of the Wainwrightian, Pelukian, and middle Wisconsin transgressions and a Holocene lag deposit (fig. 40, table 18). Sample 19-19 is barren of foraminifers and ostracodes.

Faunas considered diagnostic of the Wainwrightian transgression (samples 19-18 to 19-11) include abundant and moderately diverse foraminiferal assemblages. Foraminiferal assemblages in samples 19-18 and 19-17 are dominated by elphidiums and contain abundant cassidulinids, few Buccella frigida (average 5\%), and rare outer neritic species. Middle neritic and deeper water foraminiferal species make up approximately 39 percent of the assemblages in samples 19-18 and 19-17. These samples were taken from coarse-grained sediments interpreted as a beach deposit (sample 19-18) and from silty clays $1.4 \mathrm{~m}$ above the beach deposit (sample 19-17). Because the sedimentary difference between these two samples is not reflected in the foraminiferal assemblage, particularly in the abundance of the deeper water species, the presence of the deeper water species may be due to reworking of older material. This interpretation is supported by amino acid ratios based on foraminifers. Alle/ Ile ratios of 0.140 to 0.147 and 0.075 are given for these samples by P.A. Smith (written commun., 1986). She reports that the ratio of 0.075 is about average for Wainwrightian sediments $(0.073)$, whereas the ratio of 0.140 to 0.147 is too high and suggests contamination by older material. Excluding the deeper water species, which are probably reworked, these samples appear to have been deposited in the shallow inner neritic biofacies. Common to abundant Elphidium orbiculare and $E$. incertum in the assemblages indicate a cold, shallow, low-salinity water mass. 


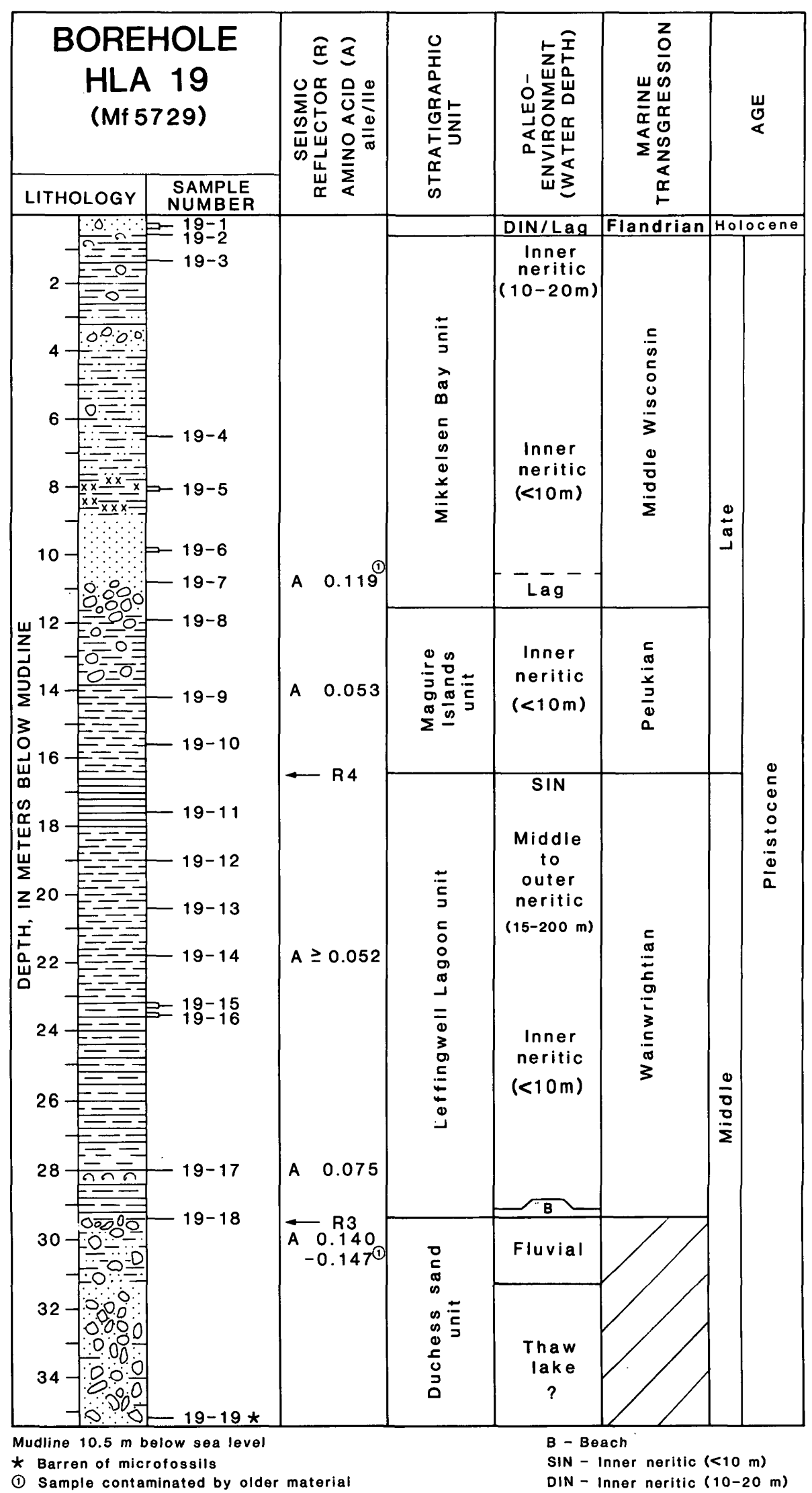

Figure 39. Lithology, sample locations, lithostratigraphic units, paleoenvironments, and ages of borehole HLA 19, Beaufort Sea shelf, Alaska. Paleoenvironment contact dashed where approximate. Lithostratigraphic units and transgressions summarized in figures 4 and 5 and in figures 2 and 3 , respectively. $R$, seismic reflector surface. 


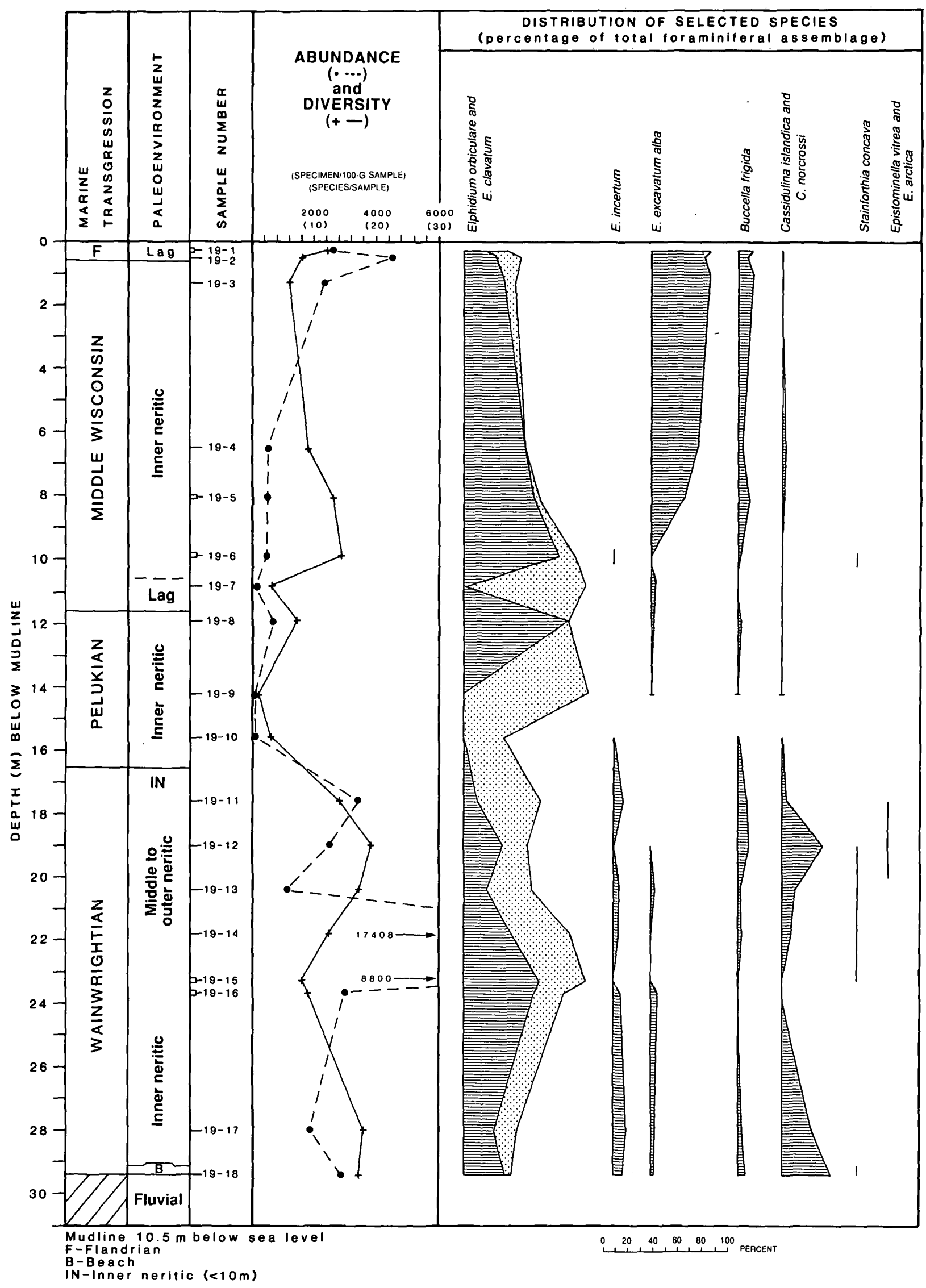

Figure 40. Benthic foraminiferal abundance (dot or number) and diversity (cross) and distribution of selective species in borehole HLA 19, Beaufort Sea shelf, Alaska. See table 18 for foraminiferal values. Paleoenvironment contact dashed where approximate. Transgressions summarized in figures 2 and 3. 
Foraminiferal assemblages in samples $19-16$ to $19-14$ are dominated by the shallow inner neritic Elphidium clavatum and E. orbiculare. In samples 19-13 and 19-12, elphidiums decrease in abundance while deep inner and middle neritic species increase. Sample 19-12 includes abundant cassidulinids (33\%), common Buccella frigida $(9 \%)$, and rare to common outer neritic and deeper water species (Astrononion gallowayi, Nonionella auricula, and Cassidulina crassa). This assemblage indicates at least middle neritic and probably outer neritic biofacies (35-200 $\mathrm{m})$ as well as the presence of a warmer water mass. The increased abundance of elphidiums in sample 19-11 suggests a return to shallower water depths or an increase in downslope transport. Reworked specimens are rare in samples 19-16 to 19-11.

Few foraminifers occur in the Pelukian sunples 19-10 and 19-9, but a more abundant, low-diversity foraminiferal assemblage occurs in Pelukian sample 19-8. Elphidium clavatum, which is the only elphidium in sample 19-10 and the only foraminifer in sample 19-9, indicates cool, shallow inner neritic depths $(0-10 \mathrm{~m})$. Elphidium orbiculare, which dominates sample 19-8, indicates shallow inner neritic depths and low salinities. In this sample it is associated with Buccella frigida, which indicates slightly greater depths, and with Elphidium albiumbilicatum, which indicates an influx of low-salinity water and a trend toward warmer water temperatures. The four specimens of Cassidulina islandica in this sample have probably been reworked.

Faunas assigned to the middle Wisconsin transgression (samples 19-7 to 19-2) include common to abundant and low to moderately diverse foraminifers. Benthic foraminiferal assemblages increase in abundance upsection in the middle Wisconsin interval. Elphidium clavatum dominates sample 19-7 but is replaced as the dominant species by $E$. orbiculare in samples 19-6 to 19-2. Both of these species indicate the shallow inner neritic biofacies. The presence of Buccella frigida in abundances greater than 5 percent (samples 19-5, 19-3, and 19-2) suggests that deposition occurred in the deep inner neritic biofacies $(10-20 \mathrm{~m})$. Elphidium albiumbilicatum in samples 19-6 to 19-4 indicates the influx of low-salinity water. The occurrence of $E$. excavatum alba in abundances greater than 25 percent in samples 19-5 to 19-2 suggests that water temperatures were nearly as warm as today. Rare deeper water (middle neritic to upper bathyal) foraminifers that occur throughout this interval indicate reworking of older material. Foraminifers, therefore, indicate that deposition occurred in the shallow inner neritic biofacies for samples 19-7 and 19-6 and in the deeper inner neritic biofacies for samples 19-5 to 19-2.

In the Holocene lag deposit, sample 19-1, foraminifers are abundant and moderately diverse. Moderate abundances of Buccella frigida (12\%) suggest that deposition occurred in the deep inner neritic biofacies. However, the occurrence of these specimens in lag deposits suggest that they may be entirely reworked from underlying deposits.

\section{BOREHOLE HLA 20 (Mf5730)}

Borehole HLA 20 was drilled $4.8 \mathrm{~km}$ north of Karluk Island, seaward of the barrier island chain (fig. 1). Sedimentary units in HLA 20 include (oldest to youngest) Duchess sand unit, Leffingwell Lagoon unit, Maguire Islands unit, and Cross Island unit (P.A. Smith, written commun., 1986; fig. 41). An additional $0.3 \mathrm{~m}$ of sediment at the bottom of this hole is a gravel that may be part of the Shaviovik gravel unit. Unfortunately not enough of the unit was encountered to be certain of this interpretation. Seismic reflectors $\mathrm{R} 3, \mathrm{R} 4$, and $\mathrm{R}^{\prime}$ are located at $30.2 \mathrm{~m}$, $16.0 \mathrm{~m}$, and $6.7 \mathrm{~m}$, respectively. (P.A. Smith, written commun., 1986). Depths of stratigraphic units and seismic reflectors in the borehole follow.

\section{HLA 20}

\begin{tabular}{|c|c|c|}
\hline \multirow[t]{2}{*}{ Stratigraphic unit or seismic reflector } & \multicolumn{2}{|c|}{$\begin{array}{l}\text { Depth, in meters } \\
\text { below mudline }\end{array}$} \\
\hline & Top & Bottom \\
\hline 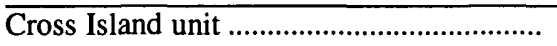 & 0.0 & 7.0 \\
\hline R5' & 6.7 & \\
\hline 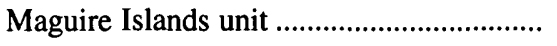 & 7.0 & 16.3 \\
\hline R4 & 16.0 & \\
\hline 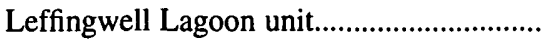 & 16.3 & 30.2 \\
\hline R3 & 30.2 & \\
\hline Duchess sand unit & 30.2 & 34.3 \\
\hline 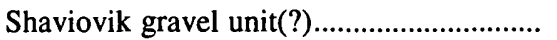 & 34.3 & 34.6 \\
\hline
\end{tabular}

Microfossil faunas sampled in borehole HLA 20 range from middle to late Pleistocene in age and represent the Wainwrightian, Pelukian, and Simpsonian transgressions (fig. 42, table 19). Sample 20-18 contains ostracodes but no foraminifers.

Wainwrightian faunas (samples 20-17 to 20-9) contain abundant and diverse foraminifers in all samples except 20-12, which has few foraminifers. Elphidiums dominate the foraminiferal assemblages. This genus generally declines in abundance upsection in this interval, except for the higher abundances noted in samples affected by increased downslope transport. The abundant Elphidium incertum, E. orbiculare, and E. clavatum in samples 20-17 and $20-16$ indicate the proximity of a cold, low-salinity water mass. Despite the common cassidulinids in samples 20-17 and 20-16, deposition probably occurred in the inner neritic biofacies $(0-10 \mathrm{~m})$. The abundance of Cassidulina islandica and $C$. norcrossi (average 51\%) in the foraminiferal assemblages, particularly in samples $20-15$ to $20-11$, indicates that water depths increased and that deposition occurred in the middle neritic biofacies $(15-40 \mathrm{~m})$. Low percentages of other middle neritic and deeper species such as Epistominella vitrea and Stainforthia concava are present in these assemblages. The increased abundance of elphidiums coupled with an increase in Buccella frigida 
Figure 41. Lithology, sample locations, lithostratigraphic units, paleoenvironments, and ages of borehole HLA 20, Beaufort Sea shelf, Alaska. Paleoenvironment contacts dashed where approximate. Lithostratigraphic units and transgressions summarized in figures 4 and 5 and in figures 2 and 3 , respectively. $R$, seismic reflector surface.

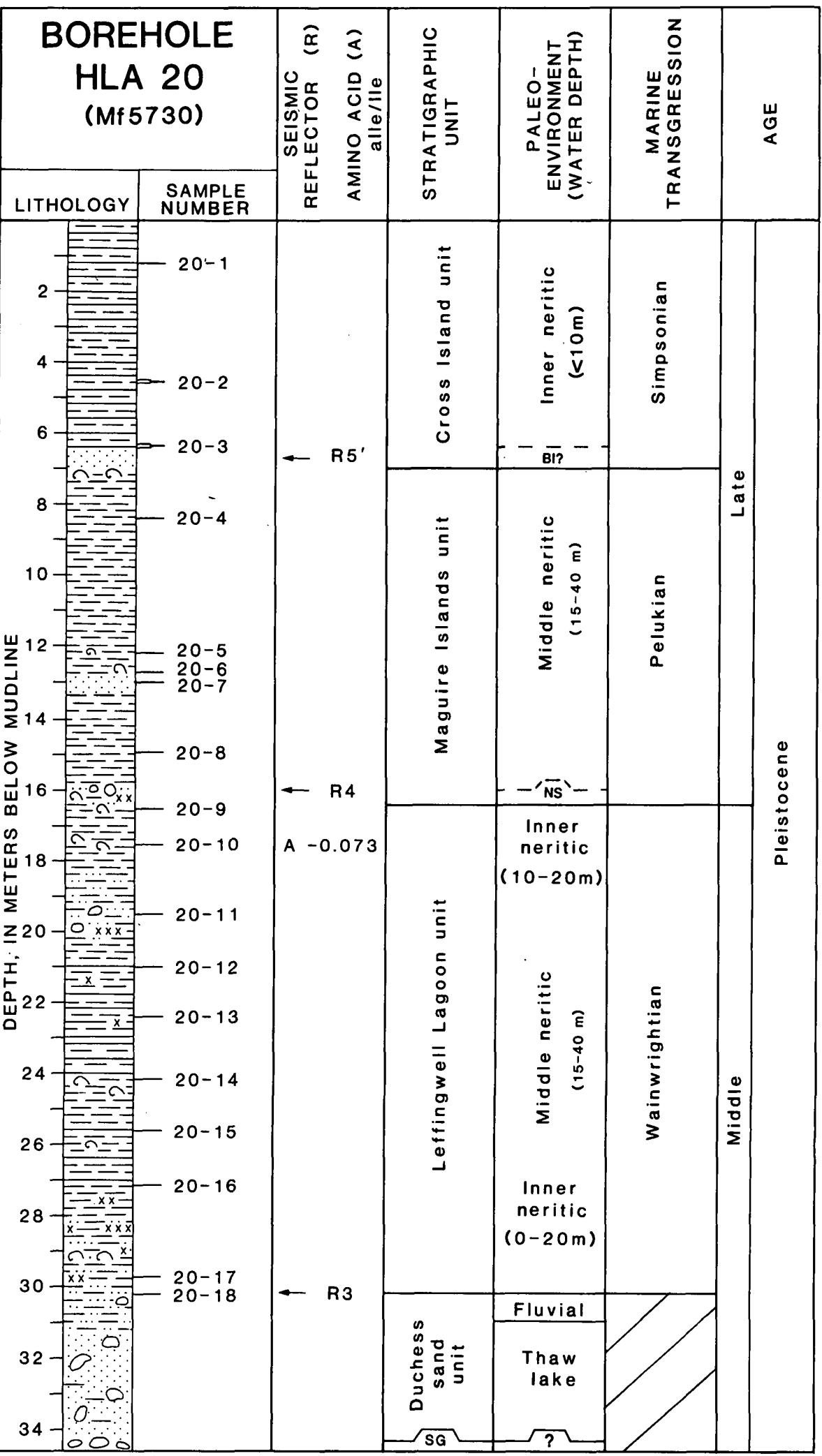

Mudline $11.3 \mathrm{~m}$ below sea level

Bl? - Barrier island?

NS - Nearshore

SG - Shaviovik gravel unit 


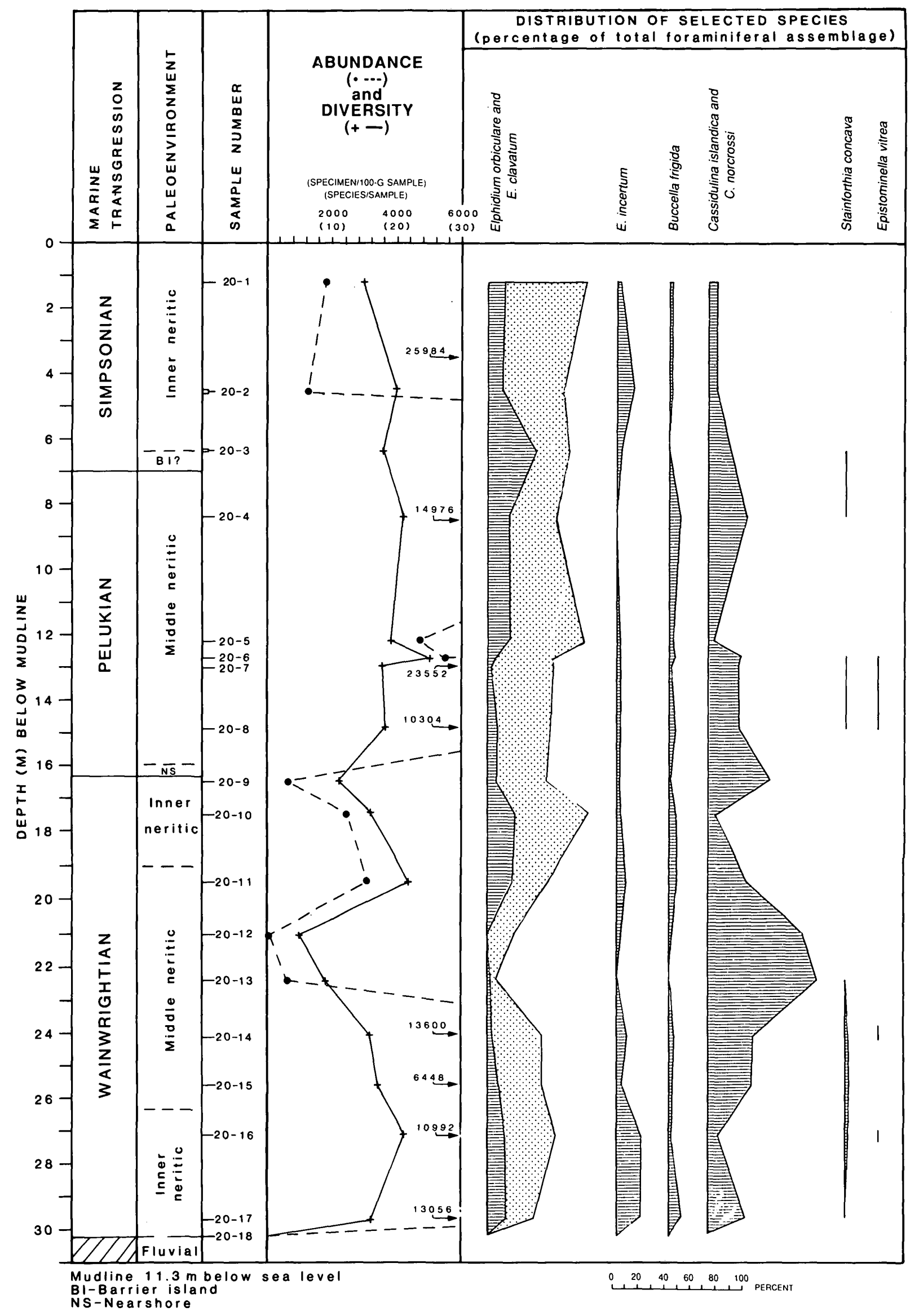


and a decrease in cassidulinids in samples 20-10 and 20-9 suggests that water depths decreased, probably to the deep inner neritic biofacies (10-20 m).

Pelukian samples 20-8 to 20-4 contain abundant and moderately to highly diverse foraminiferal assemblages that have high proportions of middle neritic species. Abundant cassidulinids suggest the middle neritic biofacies (15$40 \mathrm{~m}$ ), and abundant elphidiums suggest that currents and downslope transport supplied considerable shallow-water material. The consistent but low percentages of Epistominella vitrea, Fursenkoina schreibersiana, and Stainforthia concava indicate that water depths may have been greater, with deposition actually occurring in the outer neritic biofacies (35-200 m). The presence of Epistominella indicates the presence of a warmer Atlantic water mass. The decline in cassidulinid abundance in sample 20-5 and the corresponding increase in elphidiums suggest that water depths decreased or that downslope transport sharply increased. The latter interpretation is favored because diversity and foraminiferal number remain high, and middle to outer neritic species continue to appear.

Samples 20-3 to 20-1 represent the Simpsonian transgression and contain very abundant and moderately diverse foraminiferal assemblages. Foraminifers in sample 20-3 contain abundant cassidulinids, rare outer neritic species, and abundant elphidiums. This sample is immediately above a sandy interval that may represent a barrier island (P.A. Smith, written commun., 1985); thus, much of the foraminiferal assemblage may have been reworked from older marine deposits. The dominant species in this assemblage are $E l$ phidium orbiculare and $E$. clavatum, which are characteristic of cold, shallow, low-salinity waters. The cold-water species Elphidium incertum and the warmer water species $E$. excavatum alba are equally abundant in this sample. Buccella frigida is absent, and cassidulinids, which are probably reworked, make up 16 percent of the assemblage.

The two uppermost samples, 20-2 and 20-1, contain a shallow inner neritic foraminiferal assemblage with abundant elphidiums, few Buccella frigida, and few cassidulinids. The increased abundances of Quinqueloculina, Fissurina, Glandulina, and Guttulina suggest nearly normal marine salinities and the presence of less organic material.

\section{LATE CENOZOIC MARINE TRANSGRESSIONS}

Eight marine transgressions, Beringian, Anvillian, Fishcreekian, Wainwrightian, Pelukian, Simpsonian, middle

Figure 42. Benthic foraminiferal abundance (dot or number) and diversity (cross) and distribution of selective species in borehole HLA 20, Beaufort Sea shelf, Alaska. See table 19 for foraminiferal values. Paleoenvironment contacts dashed where approximate. Transgressions summarized in figures 2 and 3.
Wisconsin, and Flandrian, are recognized in the HLA boreholes and range in age from Pliocene to Holocene. Marine sedimentary units corresponding to these transgressions have been informally named (Smith, 1985a, b; figs. 4-7). Sediments assigned to the oldest transgressions, the Beringian (Camden Bay unit) and Anvillian (Brunlow Point unit), are restricted to HLA 18 located at the east end of the study area. The Fishcreekian (Staines River unit) is recognized in HLA 18 and HLA 12 and is questionably recognized in HLA 5, but foraminiferal assemblages were analyzed only from HLA 18 . Sediments assigned to the Wainwrightian transgression (Leffingwell Lagoon unit) are common in most of the offshore boreholes. Although the Leffingwell Lagoon unit is recognized on the basis of lithology in nearshore boreholes HLA 10 and 11, the intervals were not sampled for microfossils. Sediments of the Pelukian transgression (Maguire Islands unit) are the most pervasive and occur in most of the offshore and nearshore boreholes. The generally thick Simpsonian sediments (Cross Island unit) are common to most of the western boreholes (offshore and nearshore); they are thin or absent in the eastern boreholes. The middle Wisconsin transgression is represented by sediments (Mikkelsen Bay unit) in boreholes HLA 19 and HLA 11. Sediments assigned to the Flandrian transgression (Stefansson Sound unit) occur in the western part of the study area and in two nearshore boreholes. Lag deposits at the top of many boreholes are probably correlative with the Flandrian transgression. Faunas from these deposits are often a mixture of Flandrian and older specimens. Age and paleoecologic interpretations based on benthic foraminiferal assemblages in the HLA boreholes, as well as implications to the geologic history of the eastern Beaufort shelf, are summarized below.

\section{BERINGIAN TRANSGRESSION}

Beringian foraminiferal assemblages in the Camden Bay unit are long-ranging species, except for Elphidium ustulatum that first appears in the Pliocene and ranges into the early Pleistocene. The Pliocene age suggested for the Beringian transgression is compatible with this age range.

The single Beringian foraminiferal assemblage in HLA 18 indicates that water depths were 10 to $20 \mathrm{~m}$ (deep inner neritic biofacies), probably closer to $20 \mathrm{~m}$ because of the abundance of miliolids. This assemblage is too sparse to develop an ecological comparison with the modern environment.

\section{ANVILLIAN TRANSGRESSION}

Anvillian foraminiferal assemblages in the Brunlow Point unit contain numerous long-ranging species as well as the species Elphidium ustulatum, which has a Pliocene to early Pleistocene range. The late Pliocene age suggested for the Anvillian transgression is compatible with this range. 
Species present in the Anvillian foraminiferal assemblages indicate water depths of 15 to $40 \mathrm{~m}$ (middle neritic biofacies). Although species characteristic of warmer and deeper water masses are common, the Anvillian assemblages contain a few cold, shallow-water species such as Elphidium incertum, which indicate that water temperatures were cooler than during the Beringian. The mixture of shallow- and deep-water species suggests more downslope transport than in the Beringian transgression.

\section{FISHCREEKIAN TRANSGRESSION}

Benthic foraminifers from the Fishcreekian transgression are present only in HLA 18 . The abundance of $E l$ phidium ustulatum suggests that these assemblages are early Pleistocene in age $(1.67-0.8 \mathrm{Ma})$ because sediments of this age in the circum-Arctic region contain common to abundant $E$. ustulatum. The composition and condition of the foraminiferal assemblages and the amino acid ratios suggest that some material has been reworked. The reworking in the Fishcreekian assemblages implies extensive erosion of older material, which may have resulted from a longer glacial-interglacial cycle or a cycle in which sea level vacillated.

The benthic foraminiferal assemblages of the Fishcreekian transgression indicate deep inner neritic (10-20 $\mathrm{m})$ to middle neritic depths $(15-40 \mathrm{~m})$. Benthic foraminiferal faunas contain reworked middle to outer neritic species, in association with transported inner neritic species, and in situ deep inner neritic to middle neritic fauna. Cooler water temperatures are indicated by the common occurrence of Elphidium incertum without corresponding increases in other shallow- or cold-water species, which suggests that icebergs, shore ice or pack ice may have been present during this transgression. Striated boulder pavements in Fishcreekian strata found by Hopkins (in Carter and others, 1986), may have been produced by stranded icebergs.

\section{WAINWRIGHTIAN TRANSGRESSION}

Age-diagnostic species are absent from the neritic assemblages of the Wainwrightian transgression. Few Elphidiella groenlandica and Elphidium asklundi are present in the Wainwrightian samples. These species range through the Pliocene and most of the Pleistocene on the north slope of Alaska. Their presence, coupled with the low abundance of Elphidium excavatum alba, suggests a transgression older than Wisconsin in age. The absence of Pliocene and early Pleistocene elphidiums implies a middle Pleistocene or younger age, although this absence is not a definitive age criteria.

Paleoecological analysis of the Wainwrightian benthic foraminiferal assemblages from the Leffingwell Lagoon unit suggests that marine conditions were generally warmer than in the preceding transgression. The abundance of Elphidium incertum suggests that ice was present during much of this transgression. Analysis of the benthic foraminiferal faunas suggests that sea level was at least $20 \mathrm{~m}$ higher than at present during the maximum high stand of the Wainwrightian transgression and that the greatest water depths were in the area of boreholes HLA 12, HLA 20, and HLA 19 as suggested by contouring seismic surface 3 (Wolf and others, 1985, 1986) (fig. 43).

The first benthic foraminiferal assemblages recognized above the beach deposits in most of the Wainwrightian sediments represent the shallow inner neritic biofacies (fig. 44). These faunas are characterized by abundant elphidiums, particularly E. clavatum, E. orbiculare, and $E$. incertum. Also common are deeper inner and middle neritic specimens of Cassidulina that have been reworked from the underlying marine deposits. The abundant elphidiums suggest low-salinity, cold, shallow water. Upsection, the abundance of Elphidium clavatum, E. orbiculare, and $E$. incertum declines, while Buccella frigida and Cassidulina increase in abundance, indicating a change to the warmer, more saline waters of the deep inner neritic and middle neritic biofacies (10-20 and 15-40 m). In boreholes HLA 12, HLA 20 and HLA 19, species that are characteristic of the outer neritic biofacies $(35-200 \mathrm{~m})$ indicate the presence of the more saline but slightly cooler subsurface Arctic Water mass. The decline of Buccella frigida and the cassidulinids and the increase in the elphidiums in the upper part of the Leffingwell Lagoon unit indicate a decrease in water depths. In most boreholes Elphidium incertum is common in the youngest Wainwrightian samples and indicates an increase in ice.

The succession of benthic foraminiferal biofacies, coupled with the seismic and sedimentary data, suggests that at the onset of the Wainwrightian transgression, marine waters penetrated the Arctic coastal plain along the former drainage channels and then spread laterally as sea level rose. The initial water mass was characterized by low temperatures and low salinity. Ice in some form was commonplace at this time. Erosion and reworking of sediments also marked this early phase of the transgression. As the transgression proceeded, water depths increased in the vicinity of the offshore boreholes. Although the surface-water mass generally became warmer and more saline, a cold subsurface Arctic Water mass penetrated the coastal plain along the former drainage channels. During the maximum sea-level stand, water depths were at least $20 \mathrm{~m}$ higher than at present. As the regression began and sea level dropped, water temperatures declined and ice once again affected the marine faunas along the coastal plain. Erosion during the subsequent glacial event removed much of the Wainwrightian sediments and faunas from the nearshore region and from the Canning River channel which remained near borehole HLA 17 (fig. 44). 


\section{PELUKIAN TRANSGRESSION}

Foraminiferal assemblages assigned to the Pelukian transgression occur in most of the boreholes (figs. 45-48). Age-diagnostic species are not common in this transgression. The presence of Elphidiella groenlandica and $\mathrm{El}$ phidium asklundi and the low abundance of $E$. excavatum alba suggest a transgression older than the Wisconsin glaciation. Although not definitive criteria, the absence of Pliocene and early Pleistocene elphidiums implies a middle Pleistocene or younger age.

Paleoecologic analysis of the Pelukian benthic foraminiferal faunas indicates that water depths were only slightly greater $(+7$ to $10 \mathrm{~m})$ than at present and that water temperatures may have been slightly warmer. The initial foraminiferal faunas to develop were dominated by elphidiums, indicative of shallower inner neritic conditions (fig. 45), cooler water temperatures and lower salinities. During the maximum sea-level rise, the distribution of the benthic foraminiferal biofacies (fig. 46) indicate that water depths were slightly greater than at present.

Samples with species reworked from older, deeper water assemblages are not as common in the initial phases of the Pelukian transgression as in the Wainwrightian transgression. Reworked species are observed primarily at the base of the Maguire Islands unit in borehole HLA 12. The effects of a prograding delta and considerable transport of shallow marine and nonmarine material across the shelf are evident in the Pelukian faunas, which are represented by mixed assemblages. These mixed assemblages are composed of transported shallower water species and in situ deeper species (borehole HLA 17, figs. 35, 36, 48). Transported shallow-water faunas make up the entire fauna in some samples that are adjacent to samples with in situ deeper water faunas (borehole HLA 16, figs. 33, 34). This mixture of assemblages indicates that the Sagavanirktok, Shaviovik, and Canning Rivers were active during the Pelukian transgression. Benthic foraminiferal biofacies indicate that Pelukian water depths were slightly greater than at present during the maximum sea-level rise and that the prograding deltas and the high influx of low-salinity water and sediment affected the faunas for considerable distances seaward of the probable shoreline (fig. 46). Mixed and transported assemblages decline in the upper part of the Maguire Islands unit. Elphidium incertum generally becomes more abundant in the upper part, suggesting the return of colder water.

\section{SIMPSONIAN TRANSGRESSION}

Foraminiferal assemblages assigned to the Simpsonian transgression do not include age-diagnostic species. The presence of Elphidiella groenlandica and Elphidium asklundi and the absence of Pliocene and early Pleistocene elphidiums suggests a late early to early late Pleistocene transgression older than the Wisconsin glaciation. Elphidium excavatum alba is slightly more abundant than in assemblages of the previous transgressions.

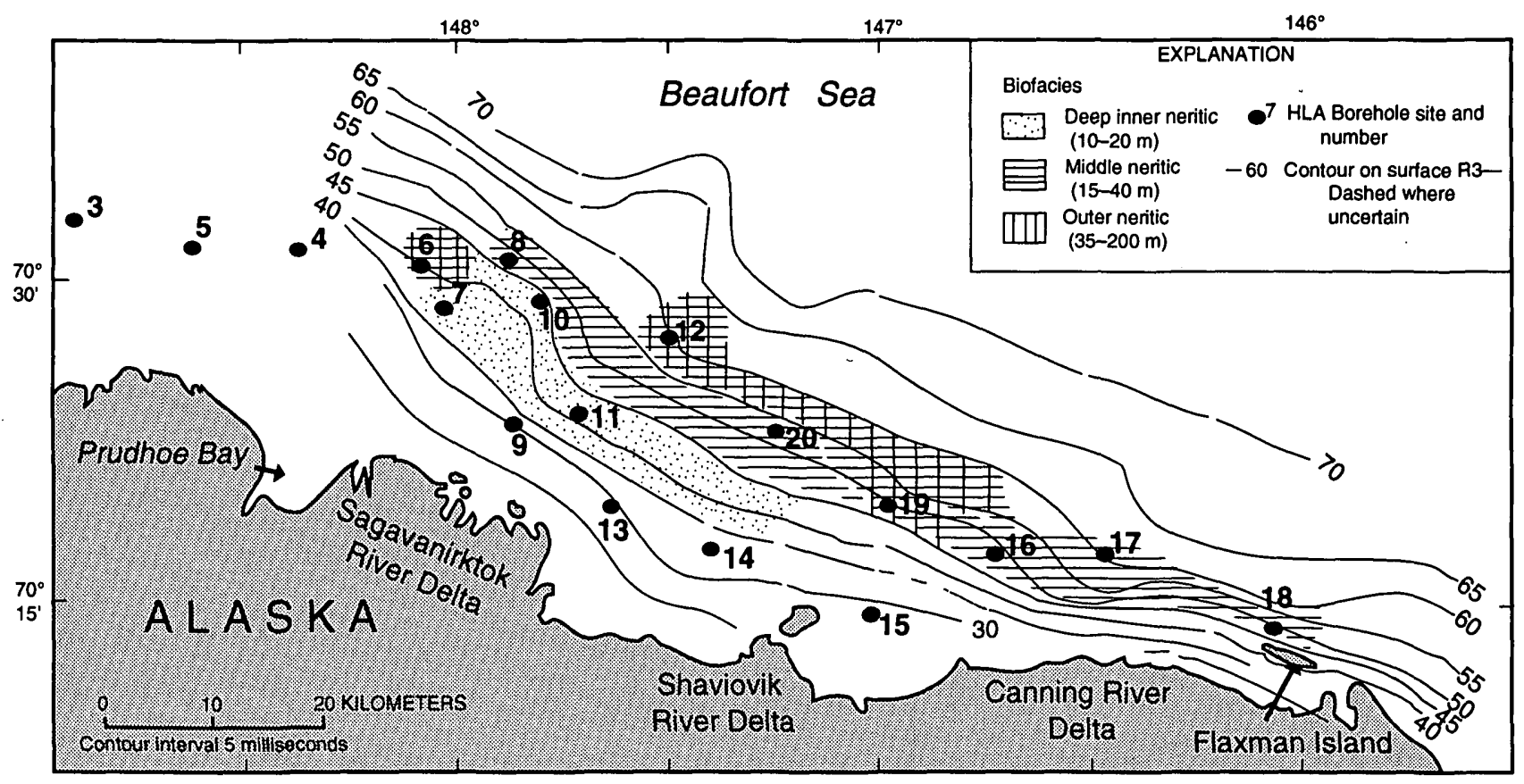

Figure 43. Distribution of benthic foraminiferal biofacies during maximum sea-level rise of the Wainwrightian transgression, Beaufort Sea shelf, Alaska. Foraminiferal biofacies are superimposed on contour map showing depth of seismic reflector surface R3 (modified from Wolf and others, 1985). 
The distribution and thickness of sediments assigned to the Simpsonian transgression (Cross Island unit; figs. 49, 50) indicate that the Sagavanirktok River was active prior to the initiation of this transgression. Sedimentologic and foraminiferal data indicate that the activity of the Saga- vanirktok River continued throughout the Simpsonian transgression and that a channel which had developed in the vicinity of boreholes HLA 9, HLA 10, and HLA 11 was filled during this transgression. Foraminiferal facies in those boreholes suggest that the high influx of river water

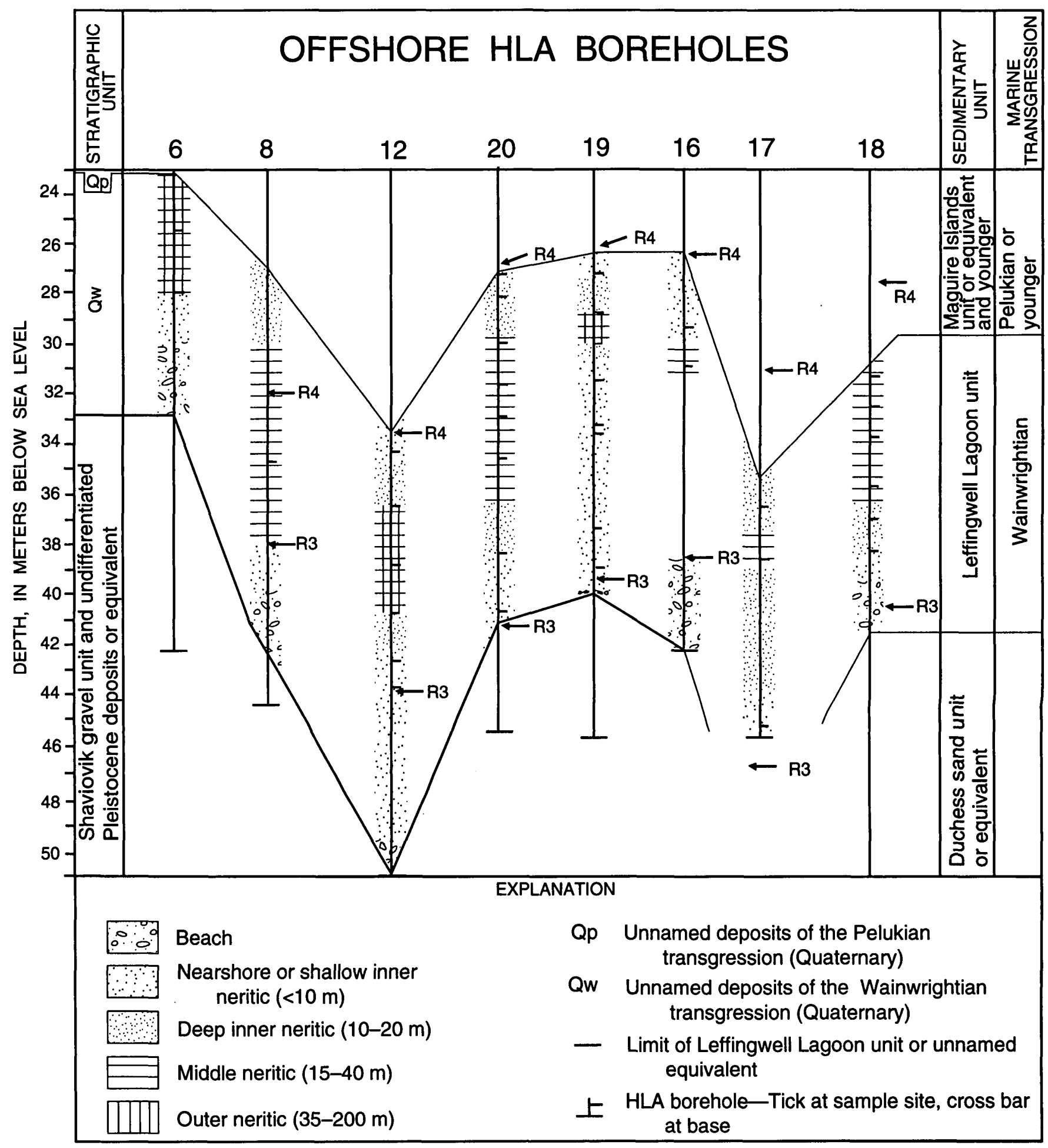

Figure 44. Cross section through offshore HLA boreholes showing distribution of sediments and foraminiferal biofacies of the Wainwrightian transgression, Beaufort Sea shelf, Alaska. R, seismic reflector surface. 
and sediment frequently obliterated the marine faunas or mixed considerable amounts of shallow-water material with in situ faunas. Paleoecologic analysis of the Simpsonian benthic foraminiferal faunas indicate that water depths during the maximum sea-level rise were approximately the same or slightly deeper than at present and temperatures were cooler. Faunas from sediments filling the Canning River channel are dominated by elphidiums.

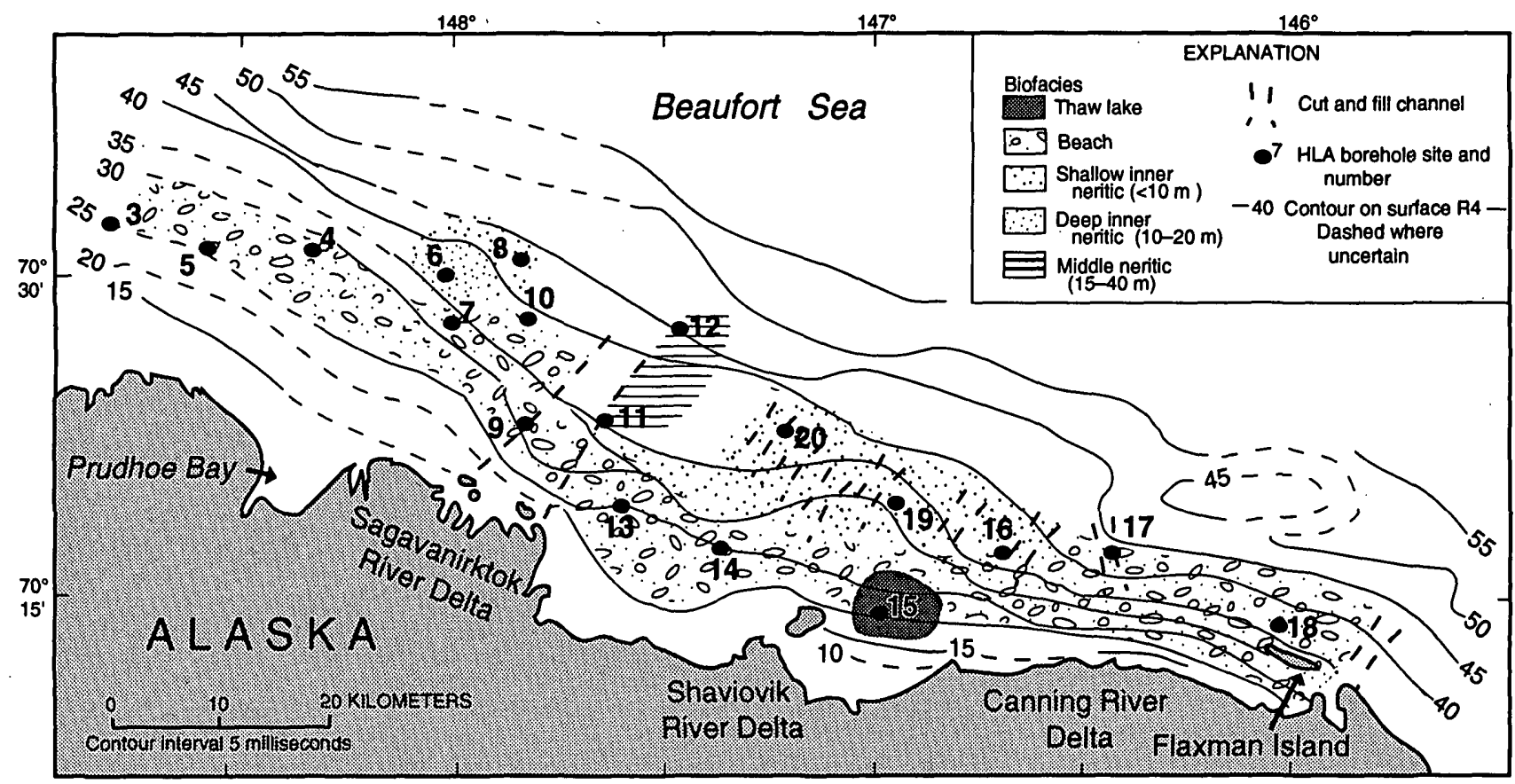

Figure 45. Distribution of benthic foraminiferal biofacies at beginning of Pelukian transgression, Beaufort Sea shelf, Alaska. Foraminiferal biofacies are superimposed on contour map showing depth of seismic reflector surface R4 (modified from Wolf and others, 1985).

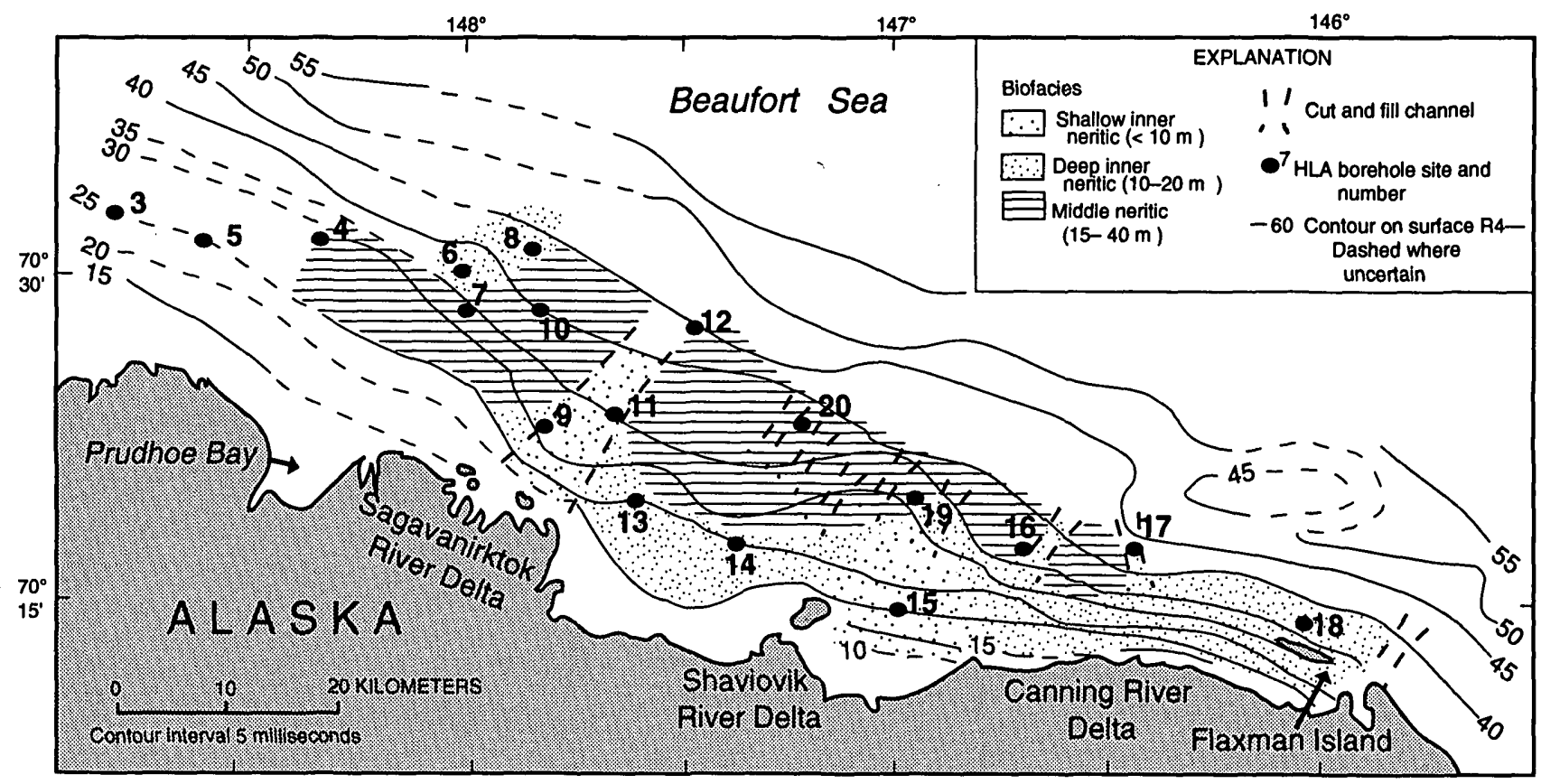

Figure 46. Distribution of benthic foraminiferal biofacies during the maximum sea-level rise of the Pelukian transgression, Beaufort Sea shelf, Alaska. Foraminiferal biofacies are superimposed on contour map showing depth of seismic reflector surface R4 (modified from Wolf and others, 1985). 


\section{MIDDLE WISCONSIN TRANSGRESSION}

Foraminiferal assemblages assigned to the middle Wisconsin transgression (Mikkelsen Bay unit) are restricted to boreholes HLA 11 and HLA 19 (figs. 49, 50). Age-diag- nostic species are not common in the younger transgressions; however, Elphidium excavatum alba is more abundant than in previous transgressions, and Elphidiella groenlandica and Elphidium asklundi are rare. Paleoecologic analysis of the benthic foraminiferal assemblages

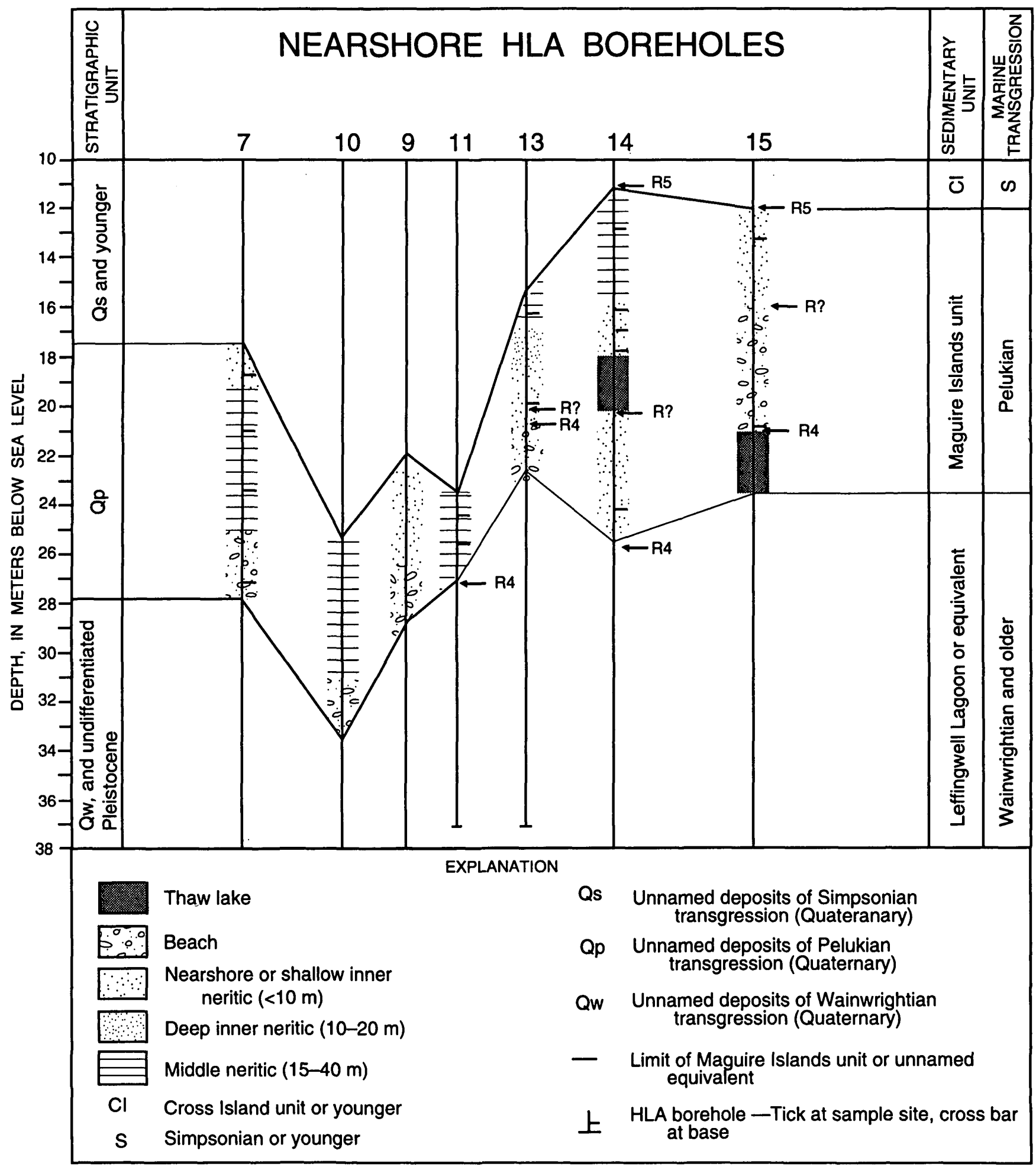

Figure 47. Cross section through nearshore HLA boreholes showing distribution of sediments and foraminiferal biofacies of the Pelukian transgression, Beaufort Sea shelf, Alaska. R, seismic reflector surface. 
suggests that changes in environmental conditions during this transgression and the foraminiferal response to them were similar to those seen in previous transgressive events. Marine waters first encroached on the shelf along the chan- nels developed by rivers during the preceding glacial event. The initial waters were shallow and cool with low salinities. During the middle Wisconsin transgression the waters warmed slightly, salinity remained low, and water

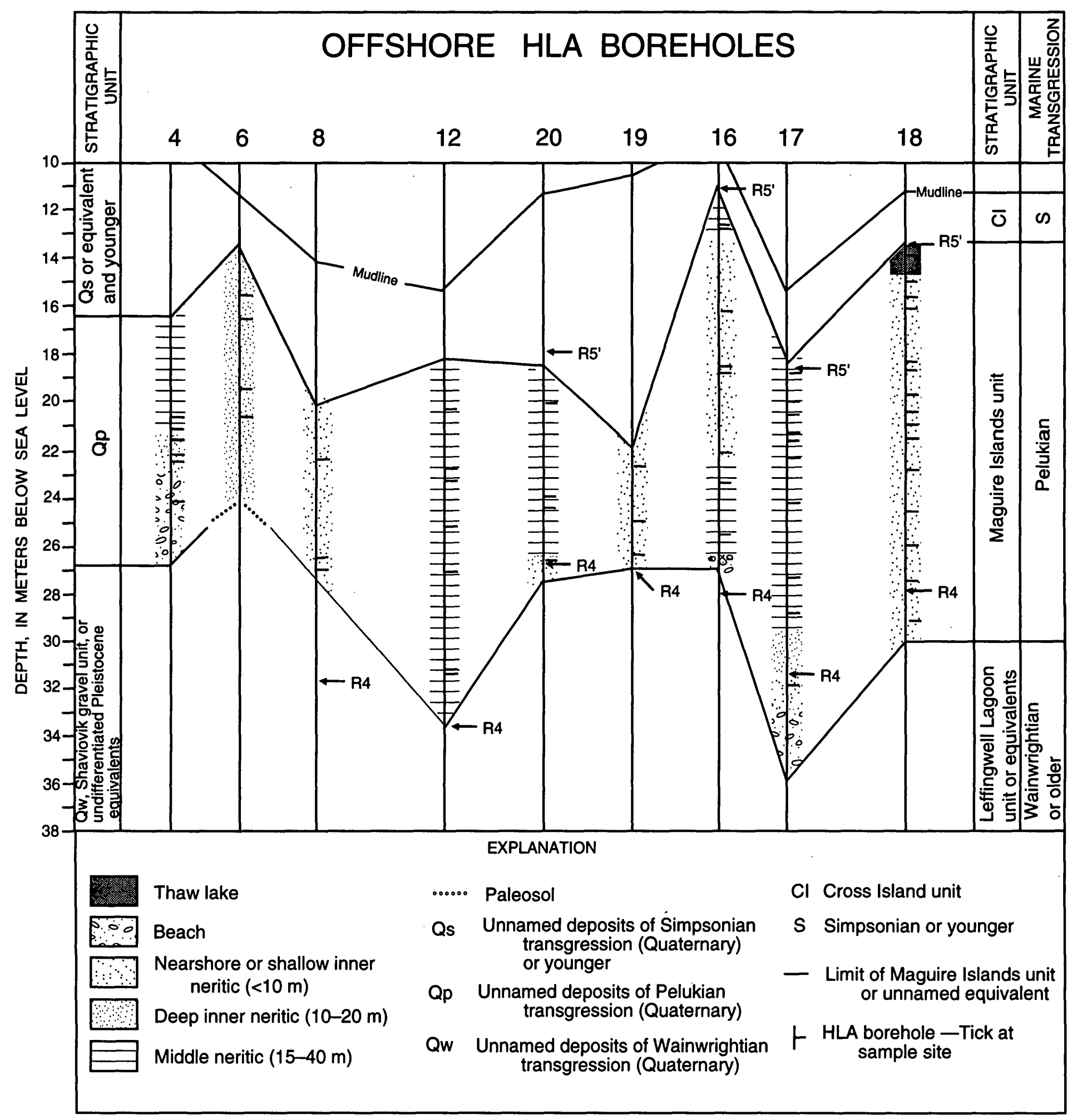

Figure 48. Cross section through offshore HLA boreholes showing the distribution of the sediments and foraminiferal biofacies of the Pelukian transgression, Beaufort Sea shelf, Alaska. R, seismic reflector surface. 
depths were about the same to slightly deeper than at present.

\section{FLANDRIAN TRANSGRESSION}

Sediments assigned to the Flandrian transgression are represented by the clays and silts of the Stefansson Sound unit (HLA 10, HLA 14, and HLA 15), the unnamed unit (Qf) in HLA 3, HLA 4, HLA 6, HLA 7, and HLA 8, and by the coarser lag deposits found in most offshore and many nearshore boreholes (figs. 49, 50). Benthic foraminiferal assemblages from the Stefansson Sound unit and the unnamed unit are primarily shallow inner neritic species. Some reworked older species are present. Foraminiferal assemblages associated with the lag deposits were sampled

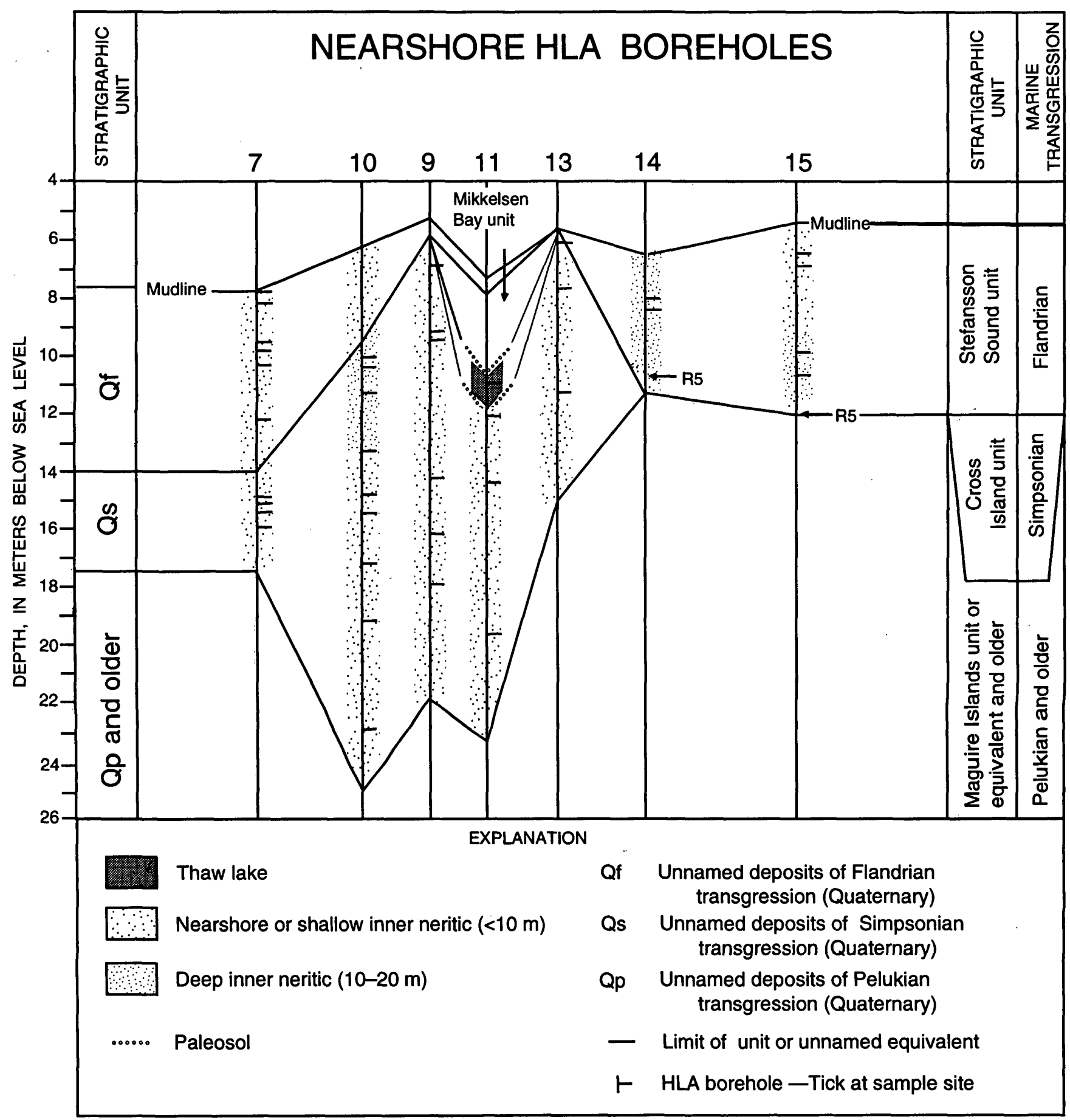

Figure 49. Cross section through nearshore HLA boreholes showing distribution of sediments and foraminiferal biofacies of the Simpsonian and younger transgressions, Beaufort Sea shelf, Alaska. R, seismic reflector surface. 


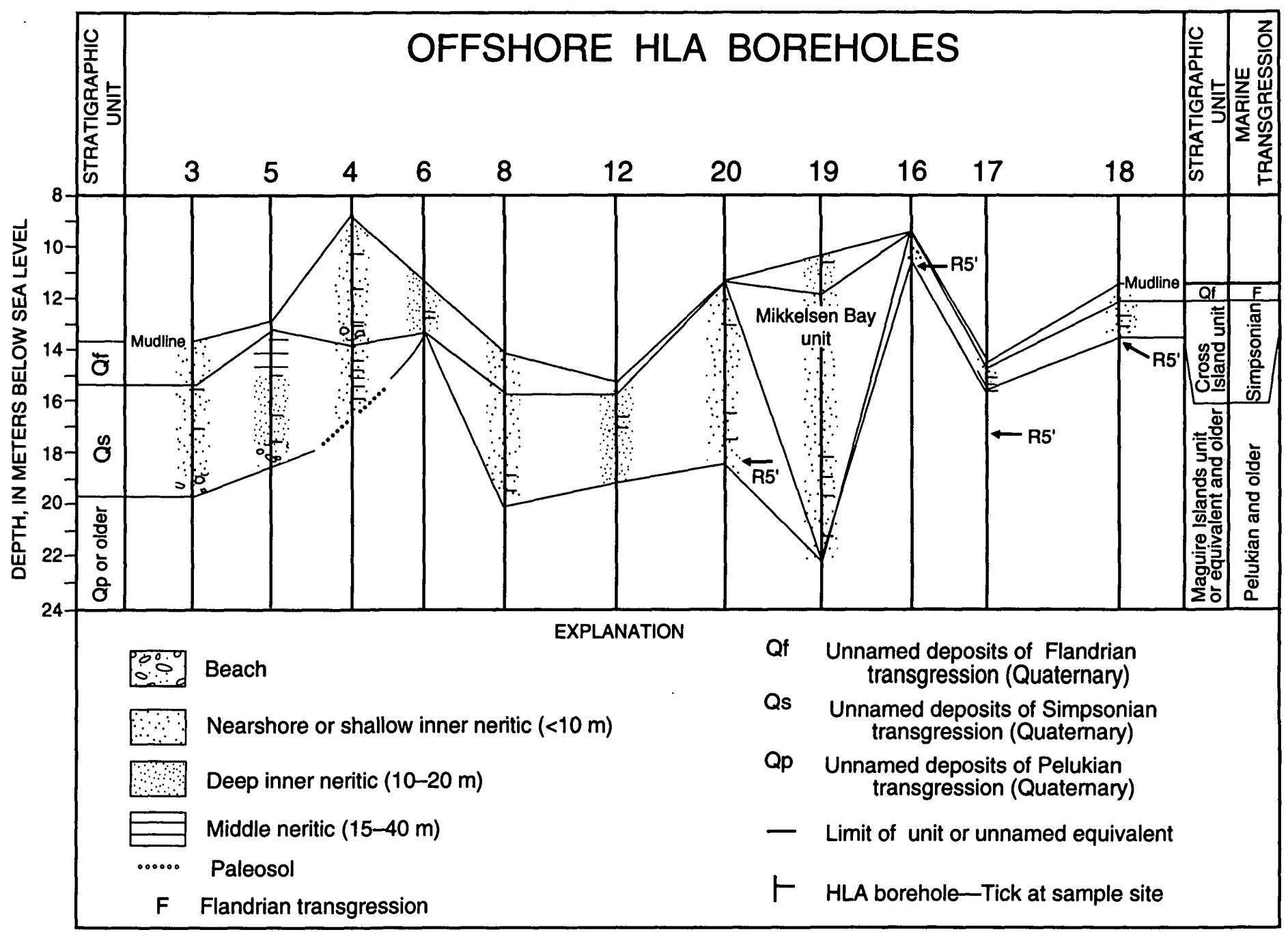

Figure 50. Cross section through offshore HLA boreholes showing distribution of sediments and foraminiferal biofacies of the Simpsonian and younger transgressions, Beaufort Sea shelf, Alaska. R, seismic reflector surface.

in boreholes HLA 7, HLA 18, and HLA 19, where reworked older material representing deeper biofacies are mixed with the in situ inner neritic species. Benthic foraminifers from the early Flandrian deposits suggest slightly cooler conditions than those suggested by living assemblages from the same areas (R.J. Echols, written commun., 1978). The increased abundance of Elphidium excavatum alba upsection and the decline in E. clavatum indicate an increase in water temperatures and a post Wisconsin age.

\section{REFERENCES CITED}

Berger, W.H., 1982, Climate steps in ocean history; lessons from the Pleistocene, in U.S. National Research Council, Climate in Earth history, studies in geophysics: Washington, D.C., National Academy Press, p. 43-54.

Brigham, J.K., 1985a, Marine stratigraphy and amino acid geochronology of the Gubik Formation, western Arctic Coastal
Plain, Alaska: Boulder, Colo., University of Colorado, Ph.D. dissertation, $312 \mathrm{p}$.

Brigham, J.K., 1985b, Marine stratigraphy and amino-acid geochronology of the Gubik Formation, western Arctic Coastal Plain, Alaska: U.S. Geological Survey Open-File Report 85381, 218 p.

Brouwers, E.M., Marincovich, Louie, Jr., and Hopkins, D.M., 1984, Paleoenvironmental record of Pleistocene transgressive events preserved at Skull Cliff, northern Alaska, in Reed, K.M., and Bartsch-Winkler, Susan, eds., The United States Geological Survey in Alaska: accomplishments during 1982: U.S. Geological Survey Circular 939, p. 9-12.

Carter, L.D., and Ager, T.A., 1989, Late Pleistocene spruce ( $P i$ cea) in northern interior basins of Alaska and the Yukon: evidence from marine deposits in northern Alaska, in Carter, L.D., Hamilton, T.D., and Galloway, J.P., eds., Late Cenozoic history of the interior basins of Alaska and the Yukon: U.S. Geological Survey Circular 1026, p. 11-14.

Carter, L.D., and Galloway, J.P., 1985, Engineering-geologic maps of northern Alaska, Harrison Bay quadrangle: U.S. 
Geological Survey Open-File Report 85-256, 47 p., scale $1: 250,000$.

Carter, L.D., Brigham-Grette, J.K., and Hopkins, D.M., 1986a, Late Cenozoic marine transgressions of the Alaskan Arctic Coastal Plain: Geological Survey of Canada Open-File Report 1237, p. 21-26.

Carter, L.D., Brigham-Grette, J.K., Marincovich, Louie, Jr., Pease, V.L., and Hillhouse, J.W., 1986b, Late Cenozoic Arctic Ocean sea ice and terrestrial paleoclimate: Geology, v. 14, no. 8, p. 675-678.

Carter, L.D., Marincovich, Louie, Jr., Brouwers, E.M., and Forester, R.M., 1979, Paleogeography of a Pleistocene coastline, Alaskan Arctic Coastal Plain, in Johnson, K.M., and Williams, J.R., eds., The United States Geological Survey in Alaska: accomplishments during 1978: U.S. Geological Survey Circular 804-B, p. B39-B41.

Coachman, L.K., and Aagaard, K., 1974, Physical oceanography of Arctic and subarctic seas, in Herman, Yvonne, ed., Marine geology and oceanography of the Arctic seas: New York, Springer-Verlag, p. 1-72.

Detterman, R.L., Bowsher, A.L., and Dutro, J.T., 1958, Glaciation on the Arctic slope of the Brooks Range, northern Alaska: Arctic, v. 11, p. 43-61.

Dinter, D.A., 1985, Quaternary sedimentation of the Alaskan Beaufort shelf: influence of regional tectonics, fluctuating sea levels, and glacial sediment sources: Tectonophysics, v. 114 , p. 133-161.

Einarsson, Thorleifur, Hopkins, D.M., and Doell, R.R., 1967, The stratigraphy of Tjörnes, northern Iceland, and the history of the Bering Land Bridge, in Hopkins, D.M., ed., The Bering Land Bridge: Stanford, Calif., Stanford University Press, p. 312-325.

Feyling-Hanssen, R.W., 1985, Late Cenozoic marine deposits of East Baffin Island and East Greenland: microbiostratigraphy, correlation, and age, in Andrews, J.T., ed., Quaternary environments: eastern Canadian Arctic, Baffin Bay, and West Greenland: Boston, Allen and Unwin, p. 354-393.

Gartner, Stefan, 1988, Paleoceanography of the mid-Pleistocene: Marine Micropaleontology, v. 13, p. 23-46.

Gladenkov, Y.B., 1981, Marine Plio-Pleistocene of Iceland and problems of its correlation: Quaternary Research, v. 15, p. 1823.

Guilbault, J.-P., 1980, A stratigraphic approach to the study of the late-glacial Champlain Sea deposits with the use of Foraminifera: Aarhus, Denmark, Aarhus University, Ph.D. dissertation, $294 \mathrm{p}$.

Hamilton, T.D., 1979, Late Cenozoic glaciations and erosion intervals, north-central Brooks Range, in Johnson, K.M., and Williams, J.R., eds., The United States Geological Survey in Alaska: accomplishments during 1978: U.S. Geological Survey Circular 804-B, p. B27-B29.

Hamilton, T.D., 1982, A late Pleistocene chronology for the southern Brooks Range: stratigraphic record and regional significance: Geological Society of America Bulletin, v. 93, no. 8 , p. $700-716$.

Hamilton, T.D., 1983, Glaciation in Arctic Alaska, in U.S. Geological Survey Polar Research Symposium-abstracts with program: U.S. Geological Survey Circular 911, p. 34-36.

Hamilton, T.D., 1986, Late Cenozoic glaciation of the Central Brooks Range, in Hamilton, T.D., Reed, K.M., and Thorson,
R.M., eds., Glaciation in Alaska, the geologic record: Anchorage, Alaska Geological Society, p. 9-49.

Hamilton, T.D., and Hopkins, D.M., 1982, Correlation of northern Alaskan glacial deposits-a provisional stratigraphic framework, in Coonrad, W.L., ed., The United States Geological Survey in Alaska: accomplishments during 1980: U.S. Geological Survey Circular 844, p. 15-18.

Hamilton, T.D., and Porter, S.C., 1975, Itkillik glaciation in the Brooks Range, northern Alaska: Quaternary Research, v. 5, p. 471-497.

Haq, B.U., Hardenbol, Jan, and Vail, P.R., 1987, Chronology of fluctuating sea levels since the Triassic: Science, v. 235 , p. 1156-1167.

Hopkins, D.M., 1967, Quaternary marine transgressions in Alaska, in Hopkins, D.M., ed., The Bering Land Bridge: Stanford, Calif., Stanford University Press, p. 47-90.

Hopkins, D.M., 1973, Sea level history in Beringian during the past 250,000 years: Quaternary Research, v. 3, p. 520-540.

Hopkins, D.M., 1982, Aspects of the paleogeography of Beringian during the late Pleistocene, in Hopkins, D.M., Mathews, J.V., Jr., Schwager, C.E., and Young, S.B., Paleoecology of Beringia: New York, Academic Press, p. 3-28.

Hopkins, D.M., Rowland, R.W., Echols, R.E., and Valentine, P.C., 1974, An Anvillian (Early Pleistocene) marine fauna from western Seward Peninsula, Alaska: Quaternary Research, v. 4 , p. $441-470$.

Jansen, E., Sejup, H-P., Fjaeran, T., Hald, M., Holte-Dahl, H., and Skarbo, O., 1983, Late Weichselian paleoceanography of the southeastern Norwegian Sea: Norsk Geologisk Tidsskrift, v. 63, p. 117-146.

Jansen, E., Slettemark, B., Bleil, U., Henrich, R., Kringstad, L., and Rolfsen, S., 1989, Oxygen and carbon isotope stratigraphy and magnetostratigraphy of the last $2.8 \mathrm{Ma}$ : paleoclimatic comparisons between the Norwegian Sea and the North Atlantic, in Eldholm, O., Theide, J., Taylor, E., and others, 1989, Proceedings of the Ocean Drilling Program, Scientific Results: College Station, Texas A\&M University, v. 104, p. 255-269.

Kaufman, D.S., Farmer, G.L., Miller, G.H., Carter, L.D., and Brigham-Grette, J.K., 1990, Strontium isotopic dating of upper Cenozoic marine deposits, northwestern Alaska, in Gosnell, L.B., and Poore, R.Z., eds., Pliocene climates: scenario for global warming: U.S. Geological Survey Open-File Report 90-64, p. 17-21.

Keller, Gerta, 1978, Late Neogene planktonic foraminiferal biostratigraphy and paleoceanography of the Northeastern Pacific: evidence from DSDP Sites 173 and 310 at the North Pacific Front: Journal of Foraminiferal Research, v. 8, p. 332349.

Keller, Gerta, and Barron, J.A., 1983, Paleoceanographic implications of Miocene deep-sea hiatuses: Geological Society of America Bulletin, v. 94, no. 5, p. 590-613.

Kent, D.V., Opdyke, N.D., and Ewing, Maurice, 1971, Climate change in the North Pacific using ice-rafted detritus as a climatic indicator: Geological Society of America Bulletin, v. 82 , no. 10 , p. $2741-2754$.

Knebel, H.J., Creager, J.S., and Echols, R.J., 1974, Holocene sedimentary framework, east-central Bering Sea continental shelf, in Herman, Yvonne, ed., Marine geology and oceanography of the Arctic seas: New York, Springer-Verlag, p. 157172. 
Knudsen, K.L., 1978, Middle and late Weichselian marine deposits at Norre Lynghy, Northern Jutland, Denmark, and their foraminiferal faunas: Danmarks Geologiske Undersogelse, ser. 2, no. 112,44 p.

Lagoe, M.B., 1979, Recent benthonic foraminiferal biofacies in the Arctic Ocean: Micropaleontology, v. 25, p. 214-224.

Lagoe, M.B., 1980, Recent Arctic Foraminifera: an overview, in Field, M.E., Douglas, R.G., and others, eds., Quaternary depositional environments of the Pacific Coast: Pacific Coast Paleogeography Symposium 4: Los Angeles, Society of Economic Paleontologists and Mineralogists, Pacific 'Section, p. 33-42.

Leffingwell, E. de K., 1919, The Canning River region, northern Alaska: U.S. Geological Survey Professional Paper 109, $251 \mathrm{p}$.

McCulloch, D.S., 1967, Quaternary geology of the Alaskan shore of the Chukchi Sea, in Hopkins, D.M., ed., The Bering Land Bridge: Stanford, Calif., Stanford University Press, p. 91120.

McDougall, Kristin, Brouwers, Elisabeth, and Smith, Peggy, 1986, Micropaleontology and sedimentology of the PB borehole series, Prudhoe Bay, Alaska: U.S. Geological Survey Bulletin 1598, 62 p.

McNeil, D.H., 1989, Foraminiferal zonation and biofacies analysis of Cenozoic strata in the Beaufort-Mackenzie Basin of Arctic Canada, in Current research, part G, Arctic Canada: Geological Survey of Canada Paper 89-1G, p. 203-223.

McNeil D.H., and Miller, K.G., 1990, High-latitude application of ${ }^{87} \mathrm{Sr} /{ }^{86} \mathrm{Sr}$ : correlation of Nuwok beds on North Slope, Alaska, to standard Oligocene chronostratigraphy: Geology, v. 18 , no. 5 , p. $415-418$.

Nelson, R.E., 1981, Paleoenvironments during deposition of a section of the Gubik Formation exposed along the lower Colville River, North Slope, in Albert, N.R.D., and Hudson, Travis, eds., The United States Geological Survey in Alaska: accomplishments during 1979: U.S. Geological Survey Circular 823-B, p. B9-B11.

Nelson, R.E., and Carter, L.D., 1985, Pollen analysis of a late Pliocene and early Pleistocene section from the Gubik Formation of Arctic Alaska: Quaternary Research, v. 24, p. 295306.

Osterman, L.E., and Nelson, A.R., 1989, Latest Quaternary and Holocene paleoceanography of the eastern Baffin Island continental shelf, Canada: benthic foraminiferal evidence: Canadian Journal of Earth Science, v. 26, p. 2236-2248.

Repenning, C.A., 1983, New evidence for the age of the Gubik Formation, Alaskan north slope: Quaternary Research, v. 19, p. 356-372.

Repenning, C.A., Brouwers, E.M., Carter, L.D., Marincovich, Louie, Jr., and Ager, T.A., 1987, The Beringian ancestry of Phenacomys (Rodentia; Cricetidae) and the beginning of the modern Arctic Ocean borderland biota: U.S. Geological Survey Bulletin 1687, $31 \mathrm{p}$.

Shackleton, N.J., and Hall, M.A., 1984, Oxygen and carbon isotope stratigraphy of Deep Sea Drilling Project Hole 522A: Plio-Pleistocene glacial history: Washington D.C., U.S. Gov- ernment Printing Office, Initial Reports of the Deep Sea Drilling Project, v. 81, p. 599-609.

Shackleton, N.J., and Opdyke, N.D., 1973, Oxygen isotope and paleomagnetic stratigraphy of equatorial Pacific core V28238: oxygen isotope temperatures and ice volumes on a $10^{5}$ and $10^{6}$ year scale: Quaternary Research, v. 3, p. 39-55.

Shackleton, N.J., and Opdyke, N.D., 1976, Oxygen-isotope and paleomagnetic stratigraphy of Pacific core V28-239, late Pliocene to latest Pleistocene, in Cline, R.M., and Hays, J.D., eds., Investigation of late Quaternary paleoceanography and paleoclimatology: Geological Society of America Memoir 145 , p. $449-464$.

Shackleton, N.J., and Opdyke, N.D., 1977, Oxygen isotope and paleomagnetic evidence for early Northern Hemisphere glaciation: Nature, v. 270, p. 216-219.

Shackleton, N.J., Backman, J.A., Zimmerman, H., Kent, D.V., Hall, M.A., Roberts., D.G., Schnitker, D., Baldauf, J.G., Desprairies, A., Homrighausen, R., Huddlestun, P., Keene, J.B., Kaltenback, A.J., Krumsiek, K.A.O., Morton, A.C., Murray, J.W., and Westberg-Smith, J., 1984, Oxygen isotope calibration of the onset of ice-rafting and history of glaciation in the North Atlantic region: Nature, v. 307, p. 620-623.

Smith, P.A., 1985a, Late Cenozoic stratigraphy of the Beaufort Sea inner shelf near Prudhoe Bay, Alaska: Dartmouth, Nova Scotia, Canada, Bedford Institute of Oceanography, Arctic Land-Sea Interaction, 14th Arctic Workshop, Abstracts, p. $25-28$.

Smith, P.A., 1985b, Late Quaternary geology of the Beaufort Sea inner shelf near Prudhoe Bay, in Bartsch-Winkler, Susan, and Reed, K.M., The U. S. Geological Survey in Alaska: accomplishments during 1983: U. S. Geological Survey Circular 945, p. 100-103.

Thorson, R.M., 1986, Late Cenozoic glaciation of the northern Nenana valley, in Hamilton, T.D., Reed, K.M., and Thorson, R.M., eds., Glaciation in Alaska, the geologic record: Anchorage, Alaska Geological Society, p. 99-122.

Todd, Ruth, 1957, Foraminifera from Carter Creek, northeastern Alaska, in Shorter contributions to general geology, 1956: U.S. Geological Survey Professional Paper 294-F, p. 223235.

Vilks, Gus, 1969, Recent Foraminifera in the Canadian Arctic: Micropaleontology, v. 15, p. 35-60.

Vilks, Gus, Wagner, F.J.E., and Pelletier, B.R., 1979, The Holocene marine environment of the Beaufort shelf: Geological Survey of Canada Bulletin, v. 303, 43 p.

Wolf, S.C., Reimnitz, Erk, and Barnes, P.W., 1985, Pleistocene and Holocene seismic stratigraphy between the Canning River and Prudhoe Bay, Beaufort Sea, Alaska: U.S. Geological Survey Open-File Report 85-549, 50 p.

Wolf, S.C., Barnes, P.W., Rearic, D.M., and Reimnitz, Erk, 1986, Shallow seismic stratigraphy between the Canning River and Demarcation Bay, Beaufort Sea, Alaska: U.S. Geological Survey Open-File Report 86-582, 33 p.

Young, F.G., and McNeil, D.H., 1984, Cenozoic stratigraphy of the Mackenzie Delta, Northwest Territories: Geological Survey of Canada Bulletin 336, 63 p. 



\section{TABLES 2-19; APPENDIXES 1, 2; INDEX; AND PLATES 1-4}

[Contact photographs of the plates in this report are available from the

U.S. Geological Survey Library, Federal Canter, Denver, CO 80225] 


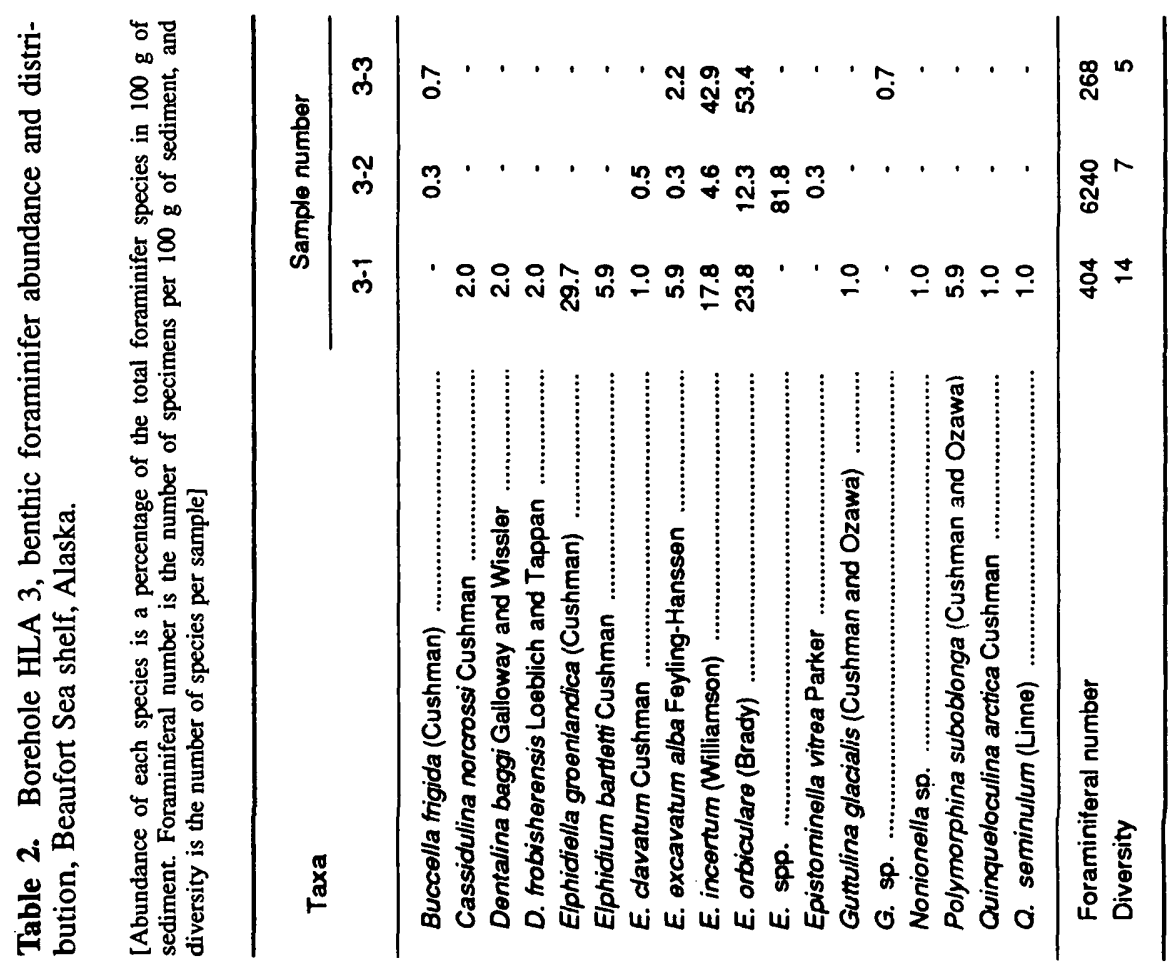




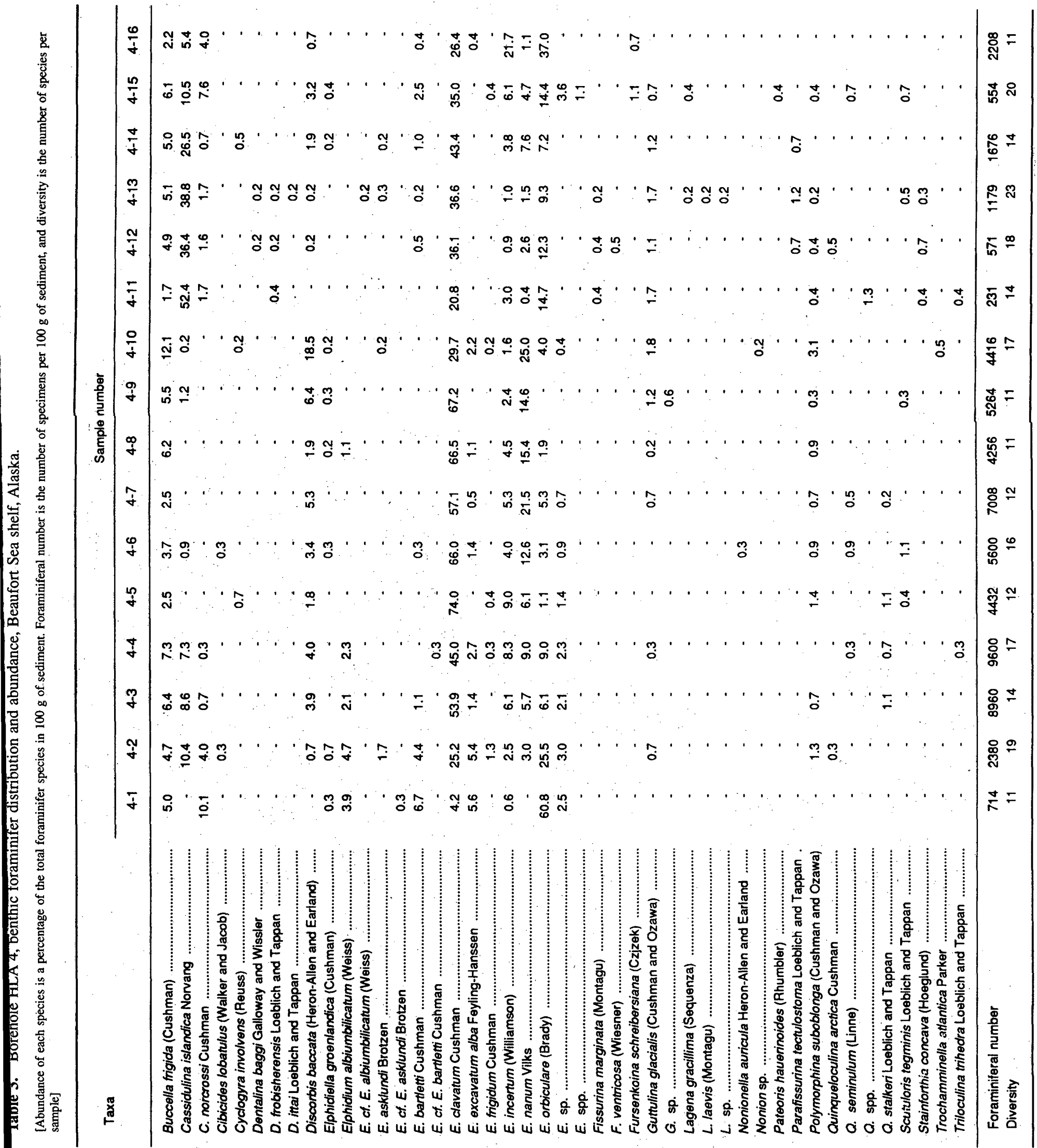



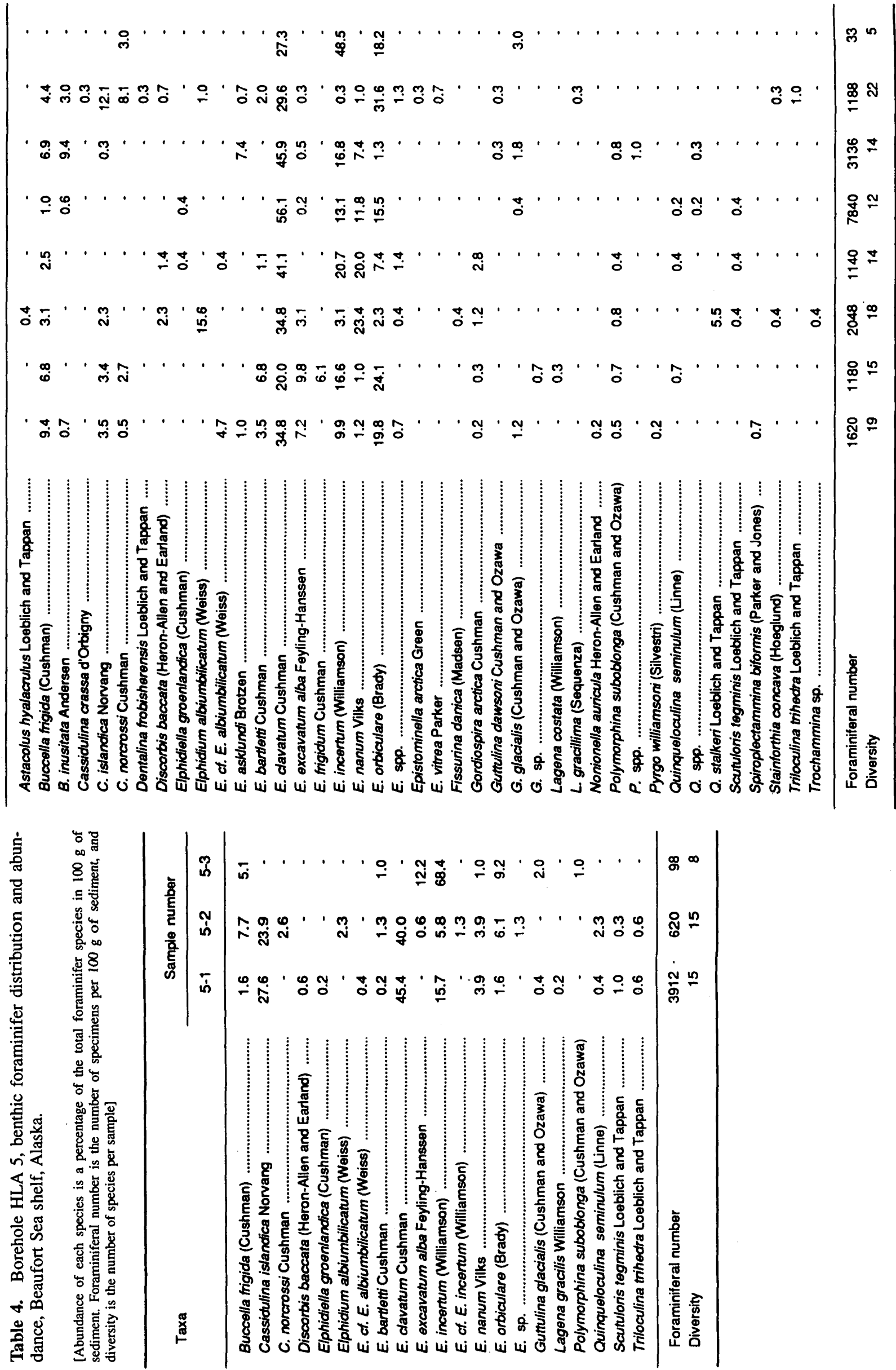


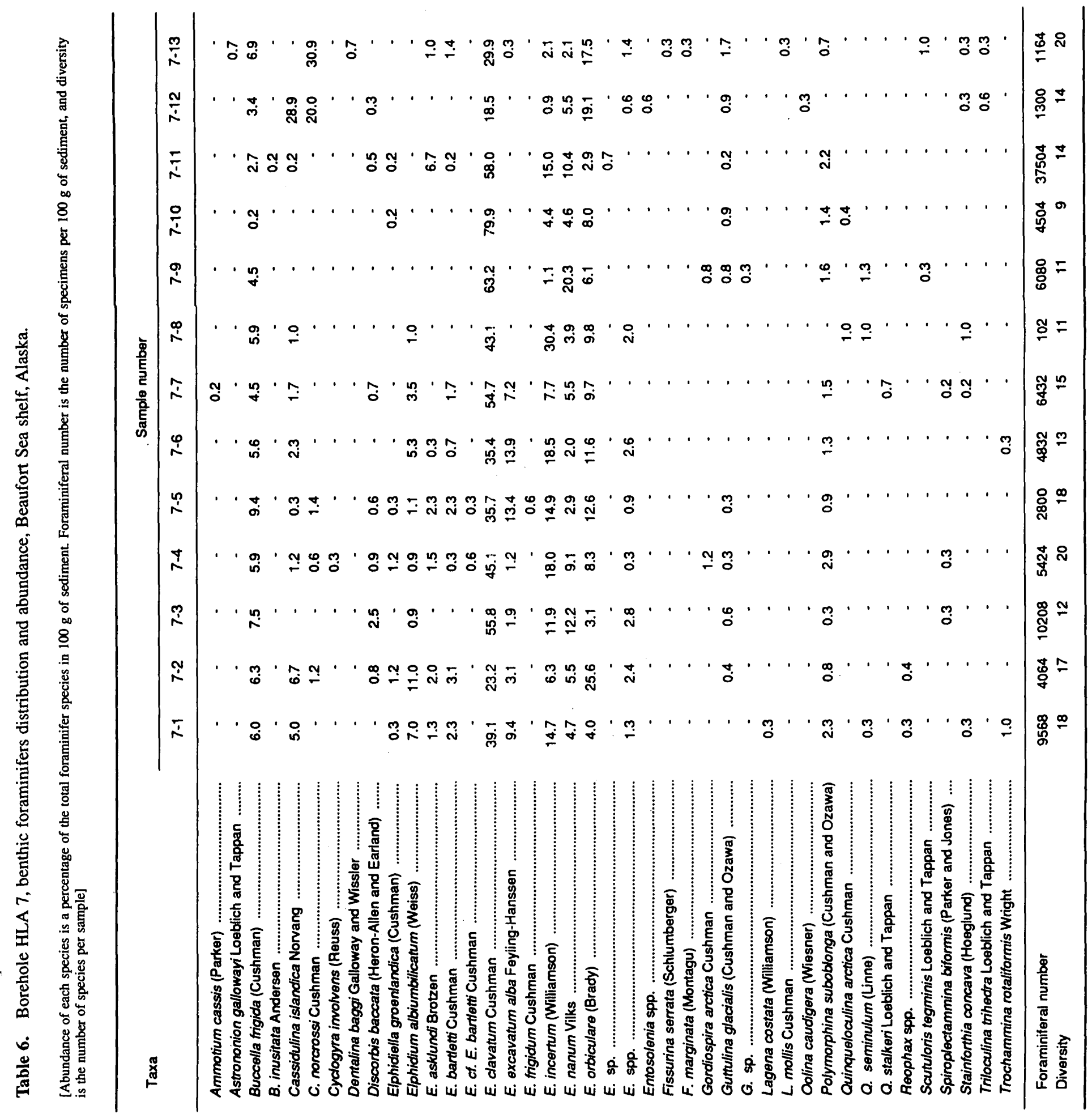



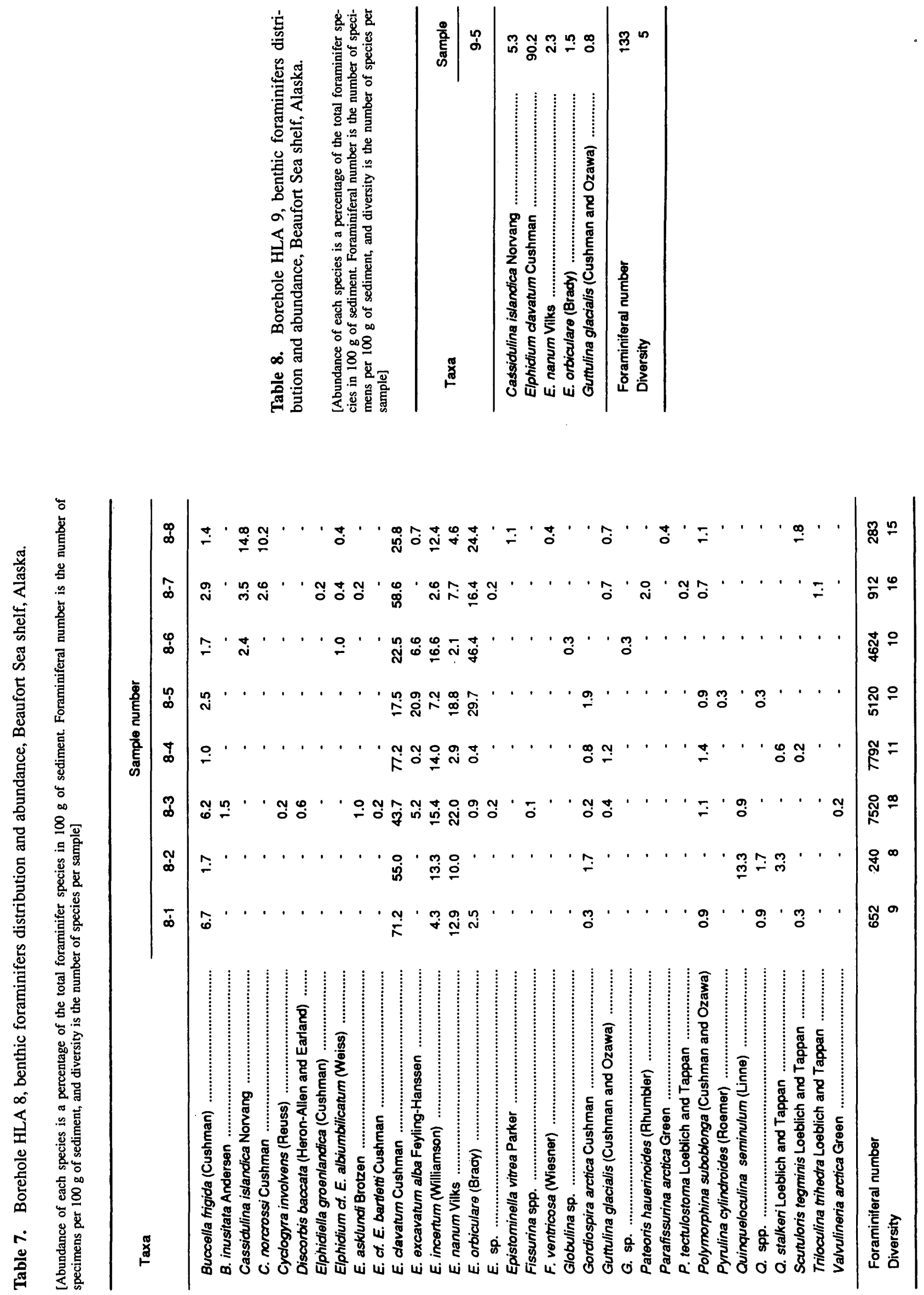

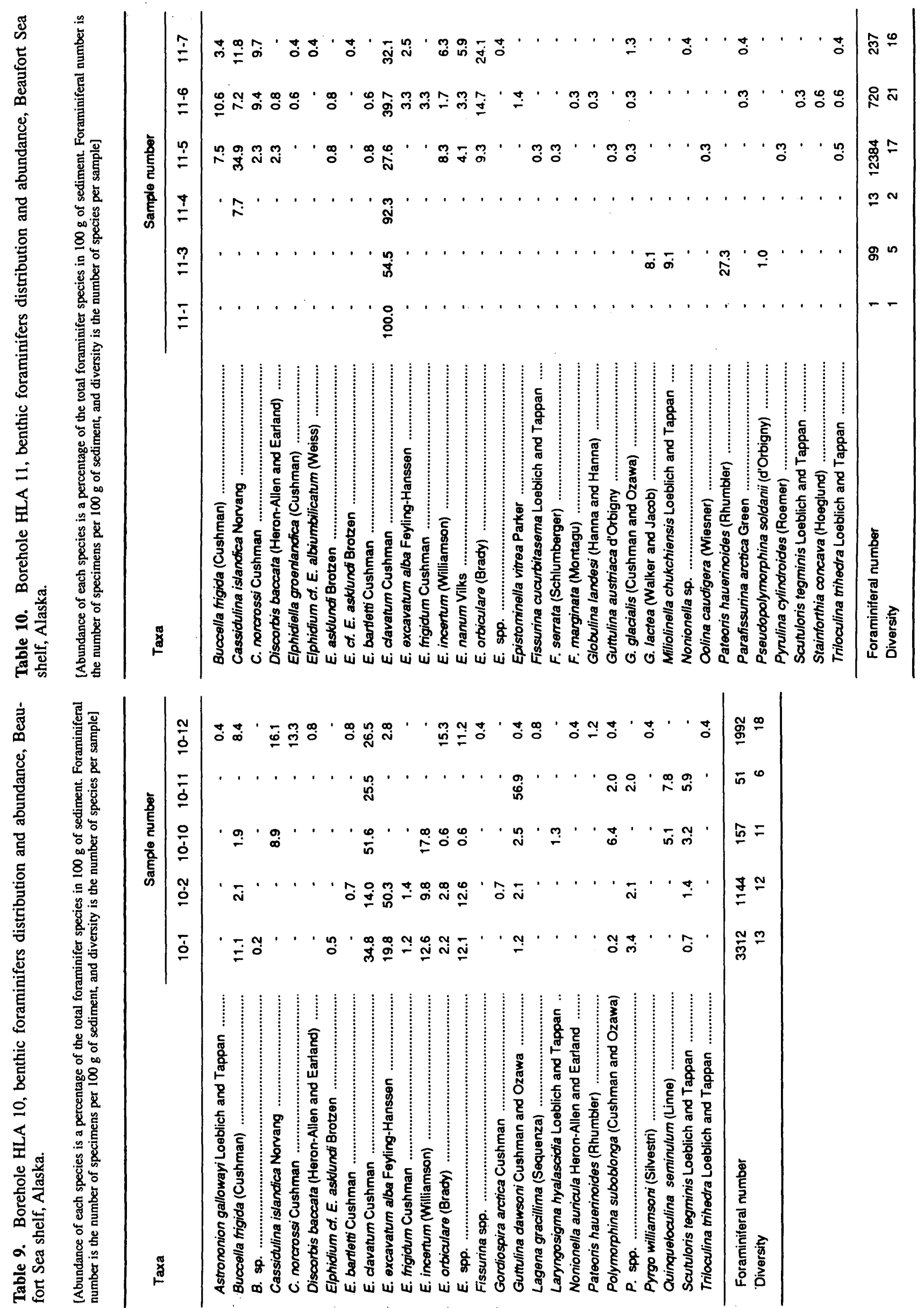


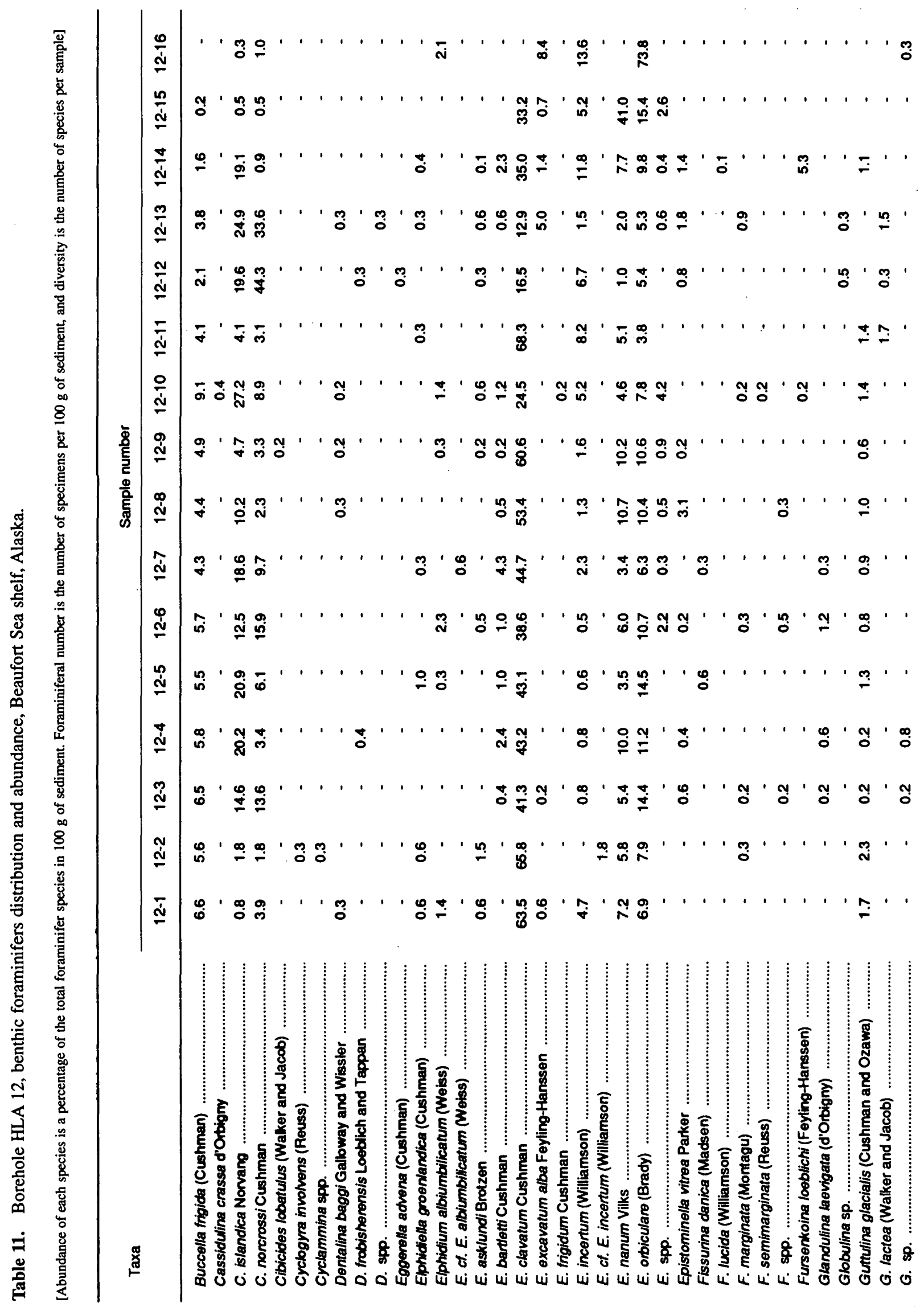




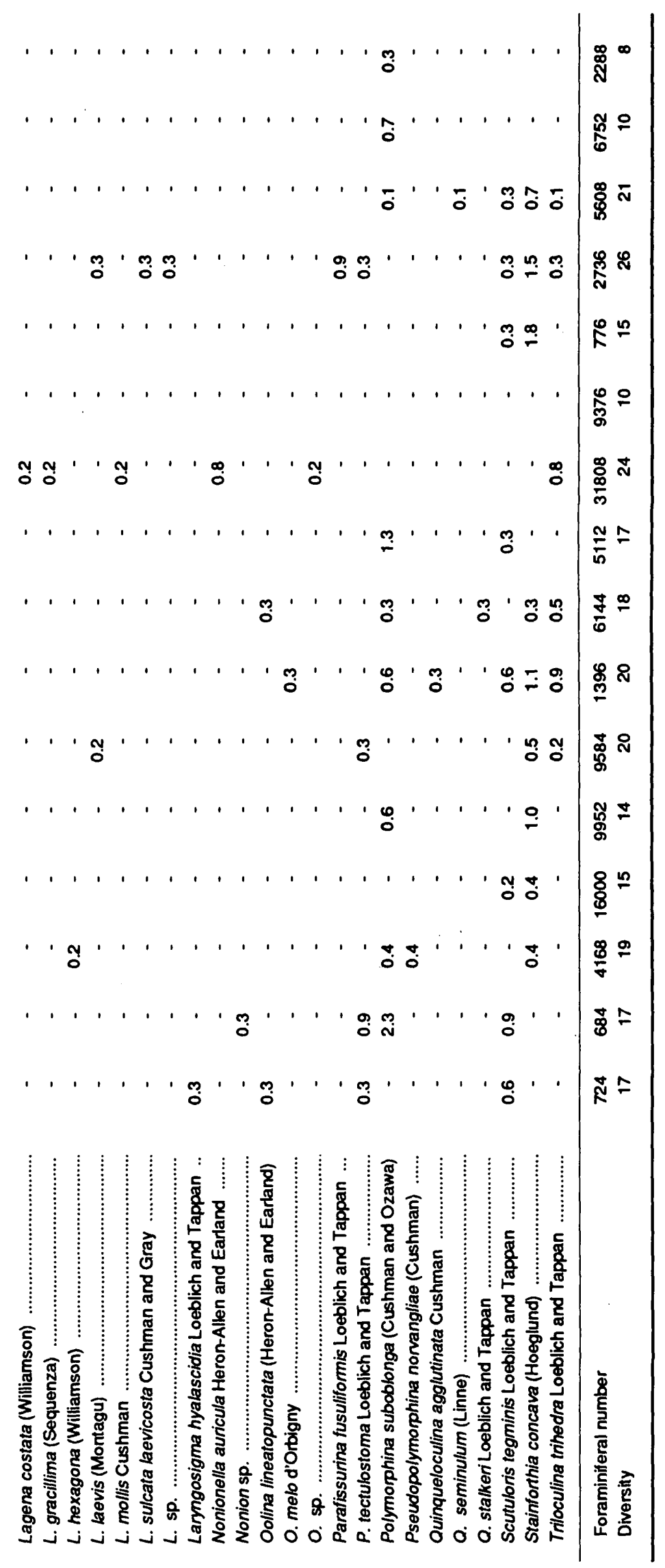


Table 12. Borehole HLA 13, benthic foraminifers distribution and abundance, Beaufort Sea shelf, Alaska.

[Abundance of each species is a percentage of the total foraminifer species in $100 \mathrm{~g}$ of sediment. Foraminiferal number is the number of specimens per $100 \mathrm{~g}$ of sediment, and diversity is the number of species per sample]

\begin{tabular}{|c|c|c|c|c|}
\hline \multirow{2}{*}{ Taxa } & \multicolumn{4}{|c|}{ Sample number } \\
\hline & 13-1 & $13-3$ & $13-4$ & $13-5$ \\
\hline Astrononion gallowayi Looblich and Tappan .......... & - & - & 0.1 & - \\
\hline 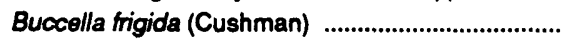 & - & - & 3.7 & - \\
\hline 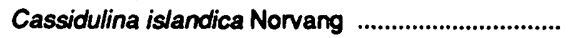 & - & - & 33.4 & - \\
\hline 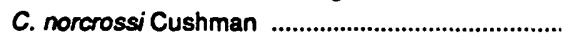 & - & • & 0.5 & • \\
\hline 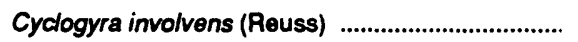 & - & - & 0.3 & - \\
\hline Dentalina baggi Galloway and Wissler ...................... & - & - & 0.3 & - \\
\hline D. frobisherensis Loeblich and Tappan .................. & $\cdot$ & - & 0.1 & - \\
\hline 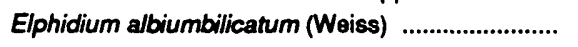 & - & - & 0.3 & - \\
\hline 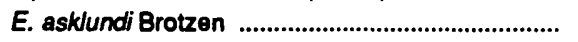 & - & - & 1.3 & - \\
\hline 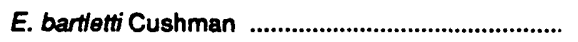 & - & - & 1.2 & - \\
\hline E. davatum Cushman & 50.0 & 91.9 & 43.2 & - \\
\hline 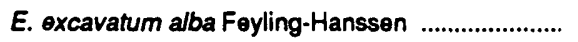 & - & 2.7 & 1.3 & 8.7 \\
\hline 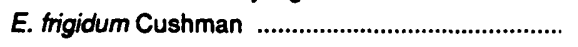 & - & $\cdot$ & - & 91.3 \\
\hline 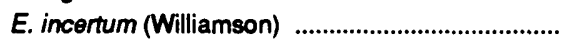 & $\cdot$ & - & 1.3 & - \\
\hline 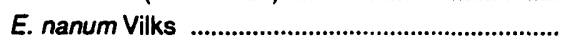 & - & 5.4 & 1.3 & - \\
\hline 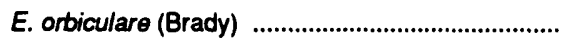 & - & - & 6.8 & . \\
\hline E. spp. & 50.0 & - & 0.3 & - \\
\hline Esosyrinx curta (Cushman and Ozawa) .................. & - & - & 0.3 & - \\
\hline 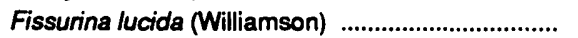 & - & - & 0.1 & - \\
\hline F. marginata (Montagu) & - & . & 0.6 & - \\
\hline Guttulina lactea (Walker and Jacob) ......................... & - & - & 0.8 & - \\
\hline Lagena distoma Parker and Jones ........................... & - & - & 0.3 & - \\
\hline 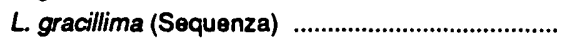 & . & . & 0.1 & - \\
\hline 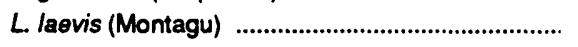 & - & $\cdot$ & 0.6 & - \\
\hline L. sp. & - & - & 0.1 & - \\
\hline Miliolinella chukchiensis Loeblich and Tappan ..... & - & - & 0.4 & - \\
\hline Parafissurina tectulostoma Loeblich and Tappan . & $\cdot$ & - & 0.4 & • \\
\hline Polymorphina suboblonga (Cushman and Ozawa) & - & - & 0.3 & - \\
\hline 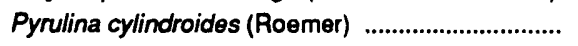 & - & - & 0.6 & - \\
\hline Triloculina trihedra Loeblich and Tappan ............... & $\cdot$ & $\cdot$ & 0.1 & - \\
\hline Foraminiferal number & 2 & 37 & 778 & 23 \\
\hline Diversity & 2 & 3 & 29 & 2 \\
\hline
\end{tabular}


Table 13. Borehole HLA 14, benthic foraminifers distribution and abundance, Beaufort Sea shelf, Alaska.

[Abundance of each species is a percentage of the total foraminifer species in $100 \mathrm{~g}$ of sediment. Foraminiferal number is the number of specimens per $100 \mathrm{~g}$ of sediment, and diversity is the number of species per sample]

\begin{tabular}{|c|c|c|c|c|c|}
\hline \multirow{2}{*}{ Taxa } & \multicolumn{5}{|c|}{ Sample number } \\
\hline & $14-1$ & $14-2$ & $14-3$ & $14-4$ & $14-7$ \\
\hline Buccella frigida (Cushman) .................................... & 13.2 & 7.1 & 3.2 & $\cdot$ & 9.3 \\
\hline B. inusitata Andersen & $\cdot$ & $\cdot$ & 0.5 & - & - \\
\hline 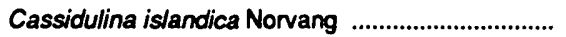 & - & $\cdot$ & 9.3 & 8.8 & 1.9 \\
\hline C. norcrossi Cushman & $\cdot$ & - & 13.4 & 13.2 & - \\
\hline Discorbis baccata (Heron-Allen and Earland) ........ & $\cdot$ & - & 1.4 & - & - \\
\hline Elphidium asklundi Brotzen ..................................... & - & 0.4 & 0.5 & - & - \\
\hline 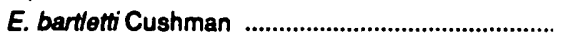 & $\cdot$ & 0.2 & - & $\cdot$ & 5.6 \\
\hline 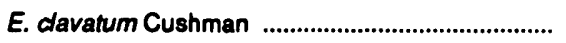 & 66.2 & 65.1 & 32.9 & 25.0 & 14.8 \\
\hline E. excavatum alba Feyling-Hanssen ......................... & - & $\cdot$ & 0.5 & 2.9 & 11.1 \\
\hline 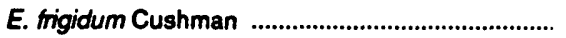 & - & - & 0.5 & - & 5.6 \\
\hline 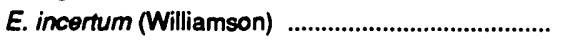 & 10.9 & 12.8 & 3.2 & 2.9 & 20.4 \\
\hline 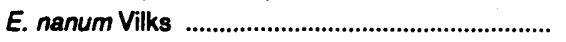 & 3.0 & 2.9 & 3.2 & - & - \\
\hline 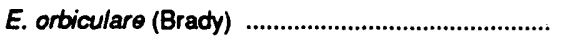 & 4.9 & 6.6 & 30.1 & 45.6 & 20.4 \\
\hline E. spp. & - & - & $\cdot$ & - & 1.9 \\
\hline Guttulina glacialis (Cushman and Ozawa) ............ & 0.1 & 0.5 & 0.9 & - & - \\
\hline 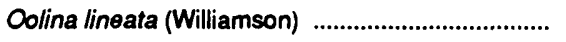 & $\cdot$ & - & 0.5 & . & - \\
\hline Polymorphina suboblonga (Cushman and Ozawa) & 1.7 & 4.1 & $\cdot$ & $\cdot$ & 9.3 \\
\hline 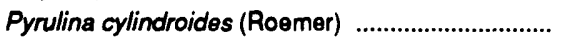 & . & 0.4 & - & $\cdot$ & $\cdot$ \\
\hline Triloculina trihodra Loeblich and Tappan ............... & - & $\cdot$ & $\cdot$ & 1.5 & $\cdot$ \\
\hline Foraminiferal number & 14080 & 17952 & 432 & 136 & 54 \\
\hline Diversity & 7 & 10 & 14 & 7 & 10 \\
\hline
\end{tabular}


Table 14. Borehole HLA 15, benthic foraminifers distribution and abundance, Beaufort Sea shelf, Alaska.

[Abundance of each species is a percentage of the total foraminifer species in $100 \mathrm{~g}$ of sediment. Foraminiferal number is the number of specimens per $100 \mathrm{~g}$ of sediment, and diversity is the number of species per sample]

\begin{tabular}{|c|c|c|c|c|}
\hline \multirow{2}{*}{ Taxa } & \multicolumn{4}{|c|}{ Sample number } \\
\hline & $15-1$ & $15-2$ & $15-3$ & $15-4$ \\
\hline 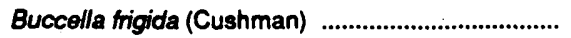 & 6.2 & 5.7 & 11.5 & 8.6 \\
\hline B. inusitata Andersen & - & 0.6 & - & - \\
\hline Cassidulina islandica Norvang ................................. & 2.6 & 0.9 & - & 1.4 \\
\hline 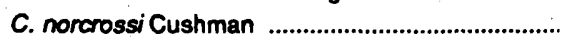 & 0.3 & $\cdot$ & $\cdot$ & $\cdot$ \\
\hline Dentalina ittai Loeblich and Tappan ....................... & 0.3 & - & - & - \\
\hline Elphidiella groendandica (Cushman) ...................... & 0.3 & 0.3 & - & 0.2 \\
\hline Elphidium albiumbilicatum (Weiss) ........................ & 3.1 . & 1.8 & 1.3 & 2.3 \\
\hline 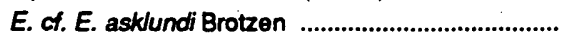 & 0.6 & - & - & 0.2 \\
\hline 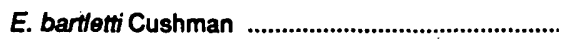 & 2.8 & 0.6 & 0.6 & 0.7 \\
\hline 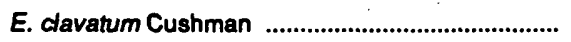 & 41.8 & 30.1 & 26.8 & 32.0 \\
\hline E. excavatum alba Foyling-Hanssen ...................... & 7.7 & 11.7 & 21.3 & 20.6 \\
\hline 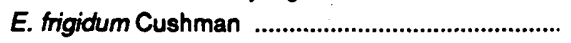 & - & 0.9 & $\cdot$ & - \\
\hline 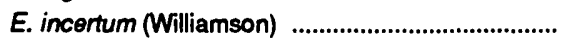 & 6.5 & 14.8 & 7.6 & 9.3 \\
\hline 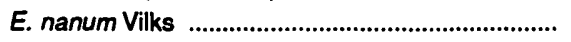 & 1.1 & 6.6 & 21.3 & 8.8 \\
\hline 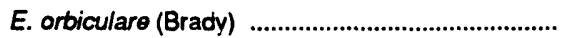 & 20.2 & 13.9 & 5.1 & 8.4 \\
\hline 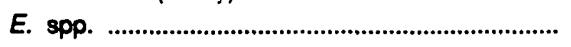 & 3.1 & 0.9 & 1.3 & 1.9 \\
\hline 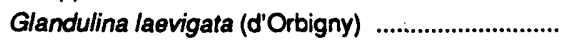 & - & 0.6 & - & - \\
\hline Guttulina dawsoni Cushman and Ozawa .............. & 0.3 & - & - & . \\
\hline G. lactea (Walker and Jacob) & 0.9 & 0.3 & 1.6 & 1.2 \\
\hline G. sp. & - & 0.3 & - & - \\
\hline 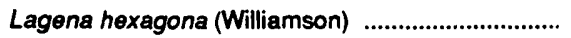 & 0.3 & - & - & 0.2 \\
\hline Polymorphina suboblonga (Cushman and Ozawa) & $\cdot$ & 4.8 & 1.6 & 2.8 \\
\hline Pullenia sp. & - & - & - & 0.2 \\
\hline Quinqueloculina seminulum (Linne) ...................... & 0.6 & 0.3 & $\cdot$ & 0.5 \\
\hline 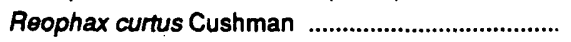 & 0.3 & - & - & - \\
\hline Trochamminella attantica Parker .............................. & 1.1 & 4.8 & $\cdot$ & 0.7 \\
\hline Foraminiferal number & 5632 & 5312 & 5024 & 862 \\
\hline Diversity & 20 & 19 & 11 & 18 \\
\hline
\end{tabular}


Table 15. Borehole HLA 16, benthic foraminifers distribution and abundance, Beaufort Sea shelf, Alaska.

[Abundance of each species is a percentage of the total foraminifer species in $100 \mathrm{~g}$ of sediment. Foraminiferal number is the number of specimens per $100 \mathrm{~g}$ of sediment, and diversity is the number of species per sample]

\begin{tabular}{|c|c|c|c|c|c|c|c|c|c|}
\hline \multirow{2}{*}{ Taxa } & \multicolumn{9}{|c|}{ Sample number } \\
\hline & $16-1$ & $16-2$ & $16-3$ & $16 \cdot 4$ & $16-5$ & $16-8$ & $16-10$ & $16-11$ & $16-12$ \\
\hline Bolivina pseudopunctata Hooglund .......................... & $\cdot$ & $\cdot$ & $\cdot$ & $\cdot$ & - & $\therefore$ & - & - & 0.1 \\
\hline 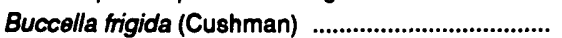 & - & 0.6 & - & 1.3 & - & - & 2.1 & 1.1 & 2.0 \\
\hline B. inusitata Andersen & 0.3 & - & - & - & - & - & - & - & - \\
\hline 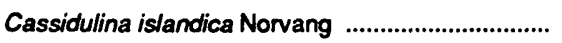 & 2.8 & 0.6 & $\cdot$ & 2.6 & - & $\cdot$ & 29.1 & 3.7 & 18.8 \\
\hline 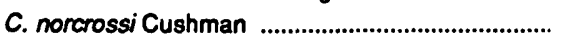 & 16.1 & 9.8 & 22.2 & 39.7 & - & - & 4.9 & - & 4.1 \\
\hline Cibicides makannai Galloway and Wissler ............. & 0.3 & - & - & - & - & - & - & - & - \\
\hline 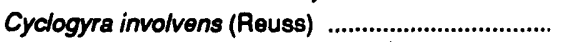 & 0.3 & - & - & $:$ & - & - & $\cdot$ & 0.5 & 0.3 \\
\hline Dentalina baggi Galloway and Wissier ................... & - & - & - & . & - & - & - & - & 0.1 \\
\hline D. frobisherensis Loeblich and Tappan .................. & 0.3 & $\cdot$ & - & - & - & - & - & - & - \\
\hline 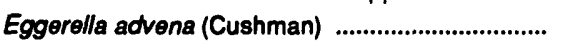 & - & - & $\cdot$ & - & - & - & 0.2 & . & - \\
\hline Elphidiella groenlandica (Cushman) ...................... & 4.7 & 4.6 & 11.1 & 2.6 & - & $\cdot$ & $\cdot$ & 1.3 & 0.1 \\
\hline 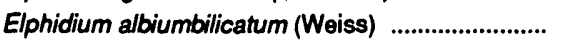 & 3.3 & 3.5 & - & 1.3 & - & - & - & - & 0.2 \\
\hline 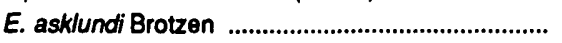 & 5.8 & - & - & $\cdot$ & - & - & $\cdot$ & - & - \\
\hline 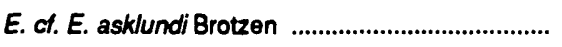 & $\cdot$ & - & $\cdot$ & - & - & $\cdot$ & - & 0.3 & - \\
\hline 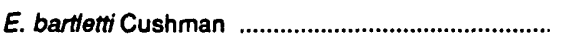 & 10.0 & 8.7 & 5.6 & 5.1 & - & $\cdot$ & $\cdot$ & $\cdot$ & 0.7 \\
\hline 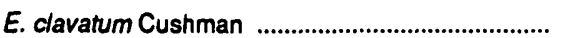 & 4.4 & 8.1 & - & 7.7 & 100.0 & 84.6 & 42.2 & 59.3 & 38.7 \\
\hline E. excavatum alba Feyling-Hanssen ....................... & 2.8 & 5.2 & 5.6 & 6.4 & - & 5.7 & 2.1 & - & 0.7 \\
\hline E. frigidum Cushman & 2.8 & - & - & - & - & $\cdot$ & : & 0.3 & - \\
\hline 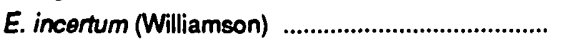 & 7.2 & 17.9 & 16.7 & 11.5 & - & - & - & 8.2 & 7.6 \\
\hline 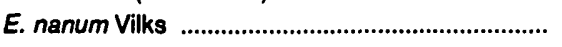 & $\cdot$ & $\cdot$ & $\cdots$ & - & $\cdot$ & $\cdot$ & 0.2 & 9.0 & 16.9 \\
\hline 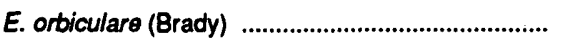 & 31.7 & 32.4 & 38.9 & 19.2 & $\cdot$ & - & 7.7 & 3.7 & 5.6 \\
\hline E. spp. & 1.1 & 1.2 & $\cdot$ & $\cdot$ & • & $\cdot$ & $\cdot$ & $\cdot$ & $\cdot$ \\
\hline 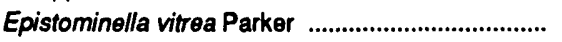 & $\cdot$ & $\cdot$ & $\cdot$ & - & $\cdot$ & - & 0.2 & - & $\cdot$ \\
\hline Esosyrinx curta (Cushman and Ozawa) ................. & 0.6 & - & - & $\cdot$ & - & $\cdot$ & 0.2 & 0.3 & - \\
\hline Fursenkoina schreibersiana (Czjzek) ...................... & 0.3 & - & - & - & - & - & $\cdot$ & - & - \\
\hline Glandulina laevigata (d'Orbigny) ................................. & - & $\cdot$ & - & $\cdot$ & - & $\cdot$ & $\cdot$ & 0.3 & - \\
\hline Gordiospira anctica Cushman .................................. & - & - & - & - & $\cdot$ & - & $\cdot$ & $\cdot$ & 0.1 \\
\hline Guttulina lactea (Walker and Jacob) ......................... & - & - & - & - & - & 0.6 & 1.3 & 1.1 & 0.8 \\
\hline G. sp. & - & $\cdot$ & $\cdot$ & - & - & $\cdot$ & $\cdot$ & $\cdot$ & 0.5 \\
\hline Miliolinella chukchiensis Loeblich and Tappan ..... & - & $\cdot$ & $\cdot$ & - & - & 9.1 & - & - & 0.4 \\
\hline Oolina caudigera (Wiesner) ..................................... & - & - & $\cdot$ & - & $\cdot$ & - & 1.7 & $\cdot$ & $\cdot$ \\
\hline Parafissurina lateralis carinata (Buchner) ............. & $\cdot$ & $\cdot$ & $\cdot$ & - & - & $\cdot$ & 1.1 & $\cdot$ & - \\
\hline Polymorphina suboblonga (Cushman and Ozawa) & 1.9 & 1.7 & $\cdot$ & - & - & - & 0.2 & 2.1 & 0.7 \\
\hline P. spp. & 0.3 & - & - & - & - & - & - & - & - \\
\hline Quinqueloculina arctica Cushman ........................... & 0.3 & - & - & $\cdot$ & - & - & - & - & $\cdot$ \\
\hline 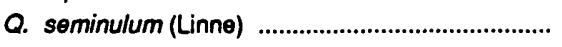 & 2.8 & 5.8 & $\cdot$ & 2.6 & $\cdot$ & $\cdot$ & $\cdot$ & 7.1 & 1.5 \\
\hline Scutuloris tegminis Looblich and Tappan .............. & - & - & - & - & - & - & - & 1.6 & - \\
\hline 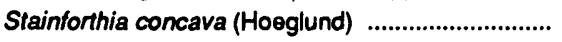 & - & - & $\cdot$ & $\cdot$ & - & $\cdot$ & 0.4 & - & 0.1 \\
\hline Trochamminella attantica Parker ............................. & - & $\cdot$ & $\cdot$ & $\cdot$ & $\cdot$ & $\cdot$ & 0.6 & - & $\cdot$ \\
\hline Triloculina trihedra Loeblich and Tappan ............... & $\cdot$ & - & - & - & - & $\cdot$ & 5.6 & 0.3 & $\cdot$ \\
\hline Foraminiferal number & 720 & 173 & 18 & 78 & 15 & 175 & 1868 & 378 & 910 \\
\hline Diversity & 22 & 13 & 6 & 11 & 1 & 4 & 17 & 17 & 21 \\
\hline
\end{tabular}


Table 16. Borehole HLA 17, benthic foraminifers distribution and abundance, Beaufort Sea shelf, Alaska.

\begin{tabular}{|c|c|c|c|c|c|c|c|c|}
\hline \multirow{2}{*}{ Taxa } & \multicolumn{8}{|c|}{ Sample number } \\
\hline & $17-1$ & $17-2$ & $17-3$ & $17-4$ & $17-5$ & $17-6$ & $17-7$ & $17-8$ \\
\hline Bolivina sp. & - & - & - & - & $\cdot$ & - & - & - \\
\hline 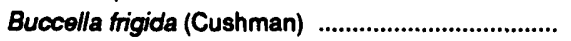 & 3.2 & 4.2 & 3.2 & 4.2 & 5.7 & 3.1 & 2.3 & 5.0 \\
\hline 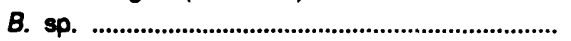 & - & - & - & - & - & - & - & - \\
\hline 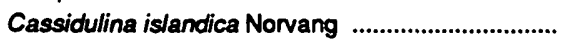 & 11.4 & 15.4 & 10.5 & 11.0 & 6.6 & 10.3 & 5.8 & 7.1 \\
\hline 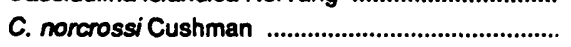 & 1.2 & 0.8 & 1.0 & - & 0.2 & 0.3 & 0.1 & 0.3 \\
\hline 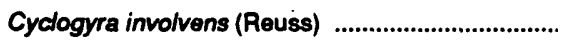 & - & 0.3 & $\cdot$ & - & $\cdot$ & - & - & - \\
\hline 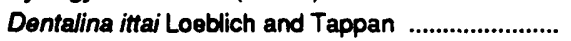 & - & - & 0.2 & - & $\cdot$ & - & $\cdot$ & - \\
\hline Discorbis baccata (Heron-Allen and Earland) ........ & 0.3 & 1.4 & 2.0 & 0.6 & 1.6 & 2.3 & 0.9 & 1.2 \\
\hline 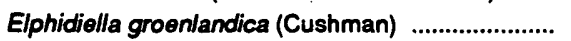 & 0.6 & 0.8 & 0.2 & • & 0.2 & - & 0.5 & 0.3 \\
\hline 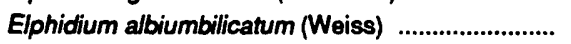 & $\cdot$ & - & - & - & 1.1 & 4.6 & 2.3 & • \\
\hline 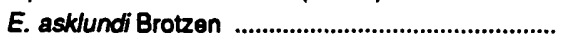 & . & 1.7 & 0.2 & 0.3 & - & 0.3 & - & - \\
\hline 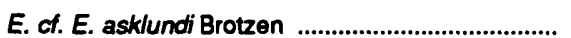 & . & . & - & . & . & - & . & - \\
\hline 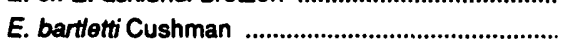 & 0.9 & 1.4 & 0.5 & - & 1.6 & 2.3 & 5.3 & 2.7 \\
\hline 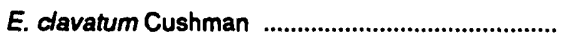 & 57.9 & 40.2 & 58.9 & 54.2 & 46.7 & 41.0 & 33.1 & 52.2 \\
\hline 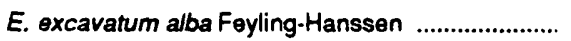 & 0.9 & 1.4 & 0.2 & 1.3 & 5.9 & 1.7 & 14.1 & 5.3 \\
\hline 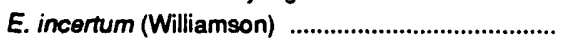 & 6.7 & 17.7 & 6.6 & 15.6 & 6.8 & 22.2 & 8.9 & 7.1 \\
\hline 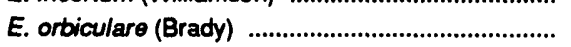 & 10.2 & 7.9 & 7.1 & 5.8 & 12.9 & 4.6 & 16.5 & 7.7 \\
\hline 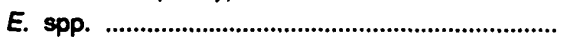 & - & - & - & - & - & - & 1.1 & 4.1 \\
\hline 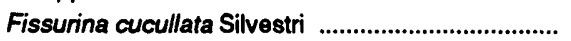 & - & . & - & - & - & - & - & - \\
\hline 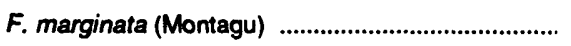 & $\cdot$ & 0.3 & 1.0 & 0.6 & - & 0.3 & 0.3 & - \\
\hline 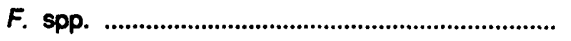 & $\cdot$ & $\cdot$ & $\cdot$ & - & $\cdot$ & $\cdot$ & $\cdot$ & - \\
\hline 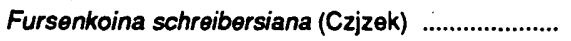 & - & - & - & - & $\cdot$ & - & $\cdot$ & • \\
\hline 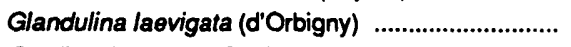 & 2.6 & 1.1 & 2.0 & 1.6 & 2.5 & 1.4 & 4.9 & 1.8 \\
\hline 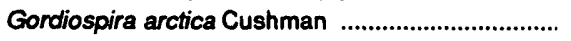 & - & - & $\cdot$ & - & 0.2 & - & - & - \\
\hline 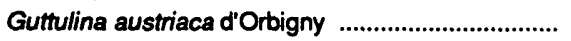 & 2.3 & 2.2 & 2.0 & 2.3 & 2.5 & 1.4 & 1.6 & 2.9 \\
\hline 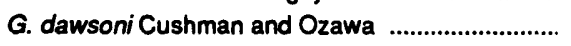 & 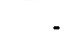 & 0.3 & 1.0 & - & 0.9 & 0.3 & 0.4 & 0.3 \\
\hline 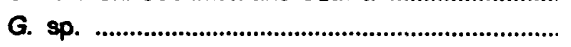 & - & . & - & - & - & - & - & - \\
\hline 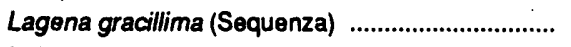 & $\cdot$ & $\cdot$ & 0.2 & $\cdot$ & $\cdot$ & - & $\cdot$ & $\cdot$ \\
\hline 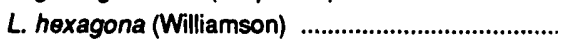 & - & - & - & - & - & 0.3 & - & - \\
\hline L. sp. . . & - & - & - & - & - & - & - & - \\
\hline Laryngosigma hyalascidia Loeblich and Tappan .. & $\cdot$ & - & 0.2 & - & $\cdot$ & $\cdot$ & $\cdot$ & - \\
\hline Miliolinella chukchiensis Loeblich and Tappan ..... & - & 1.4 & 0.5 & - & 0.5 & - & 0.3 & - \\
\hline Oolina lineatopunctata (Heron-Allen and Earland) & $\cdot$ & $\cdot$ & - & $\cdot$ & - & - & - & 0.3 \\
\hline 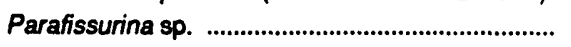 & - & - & - & - & - & - & - & - \\
\hline 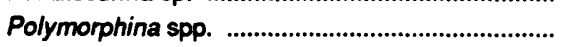 & - & - & - & - & . & - & - & . \\
\hline 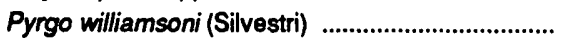 & 0.6 & - & - & - & - & $\cdot$ & - & - \\
\hline Quinqueloculina arctica Cushman ............................ & 0.6 & 0.3 & - & 0.6 & 0.5 & - & 0.4 & 0.3 \\
\hline 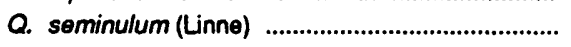 & 0.3 & 0.8 & . & 0.3 & 0.7 & 0.9 & 0.9 & 0.9 \\
\hline 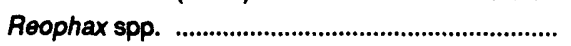 & - & - & - & - & - & - & $\cdot$ & • \\
\hline Scutuloris tegminis Loeblich and Tappan ................. & 0.3 & - & 1.2 & 1.0 & 0.5 & 0.6 & 0.3 & - \\
\hline 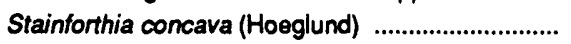 & - & 0.3 & - & - & - & - & - & - \\
\hline Triloculina trihedra Loeblich and Tappan ................ & $\cdot$ & - & 1.2 & 0.3 & 2.5 & 2.3 & 0.1 & 0.6 \\
\hline Foraminiferal number & 5472 & 2848 & 3272 & 4928 & 3528 & 11232 & 12048 & 5424 \\
\hline Diversity & 16 & 20 & 21 & 15 & 20 & 19 & 21 & 18 \\
\hline
\end{tabular}


specimens per $100 \mathrm{~g}$ of sediment, and diversity is the number of species per sample]

\begin{tabular}{|c|c|c|c|c|c|c|c|c|c|c|c|}
\hline \multicolumn{12}{|c|}{ Sample number } \\
\hline $17-9$ & $17-10$ & $17 \cdot 11$ & $17-12$ & $17-13$ & $17-14$ & $17-15$ & $17-16$ & $17-17$ & $17-18$ & $17-19$ & $17-20$ \\
\hline - & - & - & - & - & 1.1 & - & 0.4 & . & - & - & - \\
\hline 6.3 & 2.5 & 2.2 & 2.7 & 3.3 & 3.8 & 9.3 & 3.0 & 3.7 & 1.1 & 4.0 & - \\
\hline - & - & - & . & $\cdot$ & - & 2.1 & 19.8 & 0.3 & - & 6.5 & - \\
\hline 10.1 & 15.6 & 15.1 & 7.8 & 11.9 & 11.9 & 5.3 & 14.6 & 15.6 & 9.7 & 22.7 & 0.3 \\
\hline - & . & 0.2 & 0.6 & $\cdot$ & 0.3 & 0.5 & 0.6 & 6.6 & $\cdot$ & 7.9 & . \\
\hline • & 0.3 & 0.5 & - & $\cdot$ & 0.3 & - & : & $\therefore$ & - & - & - \\
\hline . & . & - & . & . & $\therefore$ & - & . & . & . & . & . \\
\hline 2.7 & 1.3 & 1.9 & 4.5 & 3.0 & 1.6 & 1.6 & . & 0.3 & 1.1 & - & 0.3 \\
\hline - & 0.6 & - & - & - & 0.6 & - & - & 0.3 & 1.1 & 0.4 & 0.9 \\
\hline 6.0 & 1.0 & 1.5 & 4.2 & 0.5 & 0.9 & - & 0.8 & 2.7 & 0.7 & 1.8 & 13.4 \\
\hline 0.3 & . & 0.2 & 0.3 & - & 0.6 & . & - & 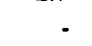 & - & . & 0.9 \\
\hline - & - & - & - & . & - & - & . & - & . & - & 1.2 \\
\hline - & 2.9 & 1.9 & 0.6 & 1.8 & 0.6 & . & - & . & - & - & 2.1 \\
\hline 32.8 & 20.3 & 12.9 & 41.8 . & 42.2 & 38.6 & 16.5 & 23.6 & 14.3 & 14.5 & 22.4 & 51.1 \\
\hline - & . & - & 0.3 & - & 0.9 & 1.9 & - & 0.3 & 0.7 & 0.4 & 1.8 \\
\hline 30.6 & 42.5 & 48.7 & 27.5 & 18.4 & 33.3 & 55.1 & 22.6 & 42.2 & 65.1 & 21.3 & 14.0 \\
\hline 7.7 & 5.1 & 5.4 & 1.5 & 2.5 & 1.3 & 4.8 & 9.6 & 9.6 & 3.3 & 9.4 & 4.9 \\
\hline . & - & - & . & 10.6 & - & - & . & 0.7 & - & 0.4 & 2.4 \\
\hline - & - & - & : & . & . & 0.5 & 0.6 & 0.7 & . & - & - \\
\hline 0.3 & - & - & - & . & . & 1.1 & 0.2 & 0.3 & . &. & - \\
\hline . & . & - & - & 0.5 & . &. & 0.2 & 0.3 & . & - & 0.3 \\
\hline - & - & - & 0.3 & . & . & - & - & . & - & . & - \\
\hline 1.4 & 2.5 & 0.5 & 1.5 & 0.3 & - & - & . & . & . & $\cdot$ & - \\
\hline - & . & . & . & . & - & . & - & - & . & - & . \\
\hline - & 3.8 & 5.8 & 3.0 & 3.0 & . & 0.3 & 0.2 & 1.0 & 0.7 & 1.4 & . \\
\hline . & 0.3 & 0.5 & . & . & - & - & 0.8 & - & 0.4 & . & 2.7 \\
\hline 0.3 & . & . & . & - & - & - & 0.2 & . & . & . & . \\
\hline - & . & - & - & - & . & - & - & . & - & - & - \\
\hline . & . & - & - & . & . & . & . & - & . & - & - \\
\hline - & $\cdot$ & - & - & . & . & $\therefore$ & . & 0.3 & . & - & . \\
\hline . & . & - & . & - & - & . & . & . & . & - & - \\
\hline . & . & 0.5 & 0.9 & . & 2.2 & 0.5 & . & . & 0.7 & - & 0.9 \\
\hline - & . & - & . & - & - & - & - & - & . & - & - \\
\hline - & . & - & . & . & $\cdot$ & 0.3 & . & 0.3 & . & - & - \\
\hline . & . & . & 0.3 & . & . & - & . & . & 0.4 & . & . \\
\hline . & - & - & - & - & - & - & . & . & - & . & . \\
\hline 0.3 & . & - & . & . & 0.6 & . & . & - & . & - & . \\
\hline - & 0.6 & 0.7 & - & 0.3 & . & . & . & . & . & . & 1.8 \\
\hline . & - & $:$ & - & - & : & - & . & . & . & . & 0.3 \\
\hline . & 0.3 & - & 0.3 & 1.3 & . & : & . & 0.3 & 0.4 & . & 0.6 \\
\hline . & . & - & . & . & - & . & 0.6 & . & . & 1.4 & - \\
\hline 1.4 & 0.3 & 1.5 & 2.1 & 0.5 & 1.3 & 0.3 & 2.2 & . & . & . & . \\
\hline 2928 & 2520 & 3288 & 5360 & 1584 & 1274 & 3008 & 4000 & 4816 & 4304 & 8864 & 5264 \\
\hline 13 & 16 & 17 & 18 & 15 & 17 & 15 & 17 & 19 & 14 & 13 & 18 \\
\hline
\end{tabular}




\section{LATE CENOZOIC BENTHIC FORAMINIFERS OF THE HLA BOREHOLE SERIES, BEAUFORT SEA SHELF, ALASKA}

Table 17. Borehole HLA 18, benthic foraminifers distribution and abundance, Beaufort Sea shelf, Alaska.

[Abundance of each species is a percentage of the total foraminifer species in $100 \mathrm{~g}$ of sediment. Foraminiferal number is the number of specimens per $100 \mathrm{~g}$ of sediment, and diversity

\begin{tabular}{|c|c|c|c|c|c|c|c|c|c|c|c|c|}
\hline \multirow{2}{*}{ Taxa } & \multicolumn{12}{|c|}{ Sample number } \\
\hline & $18-1$ & $18-2$ & 18-3 & $18-4$ & $18-5$ & $18-8$ & $18-9$ & $18-10$ & $18-13$ & $18-14$ & $18-15$ & $18-16$ \\
\hline 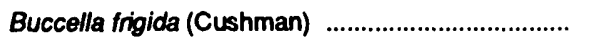 & 3.9 & 0.5 & - & $\cdot$ & 4.5 & - & - & $=$ & - & - & - & $\cdot$ \\
\hline B. inusitata Andersen & 0.3 & - & - & - & $\cdot$ & - & $\cdot$ & - & - & - & - & - \\
\hline 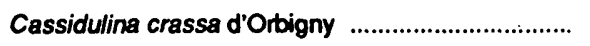 & - & - & - & - & - & - & - & - & - & - & - & - \\
\hline C. islandica Norvang & - & - & - & - & - & - & - & - & - & 14.3 & - & - \\
\hline C. norcrossi Cushman & - & - & - & - & 4.5 & - & 1.7 & - & - & - & - & - \\
\hline 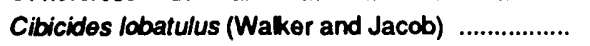 & - & - & - & - & 4.5 & - & - & - & - & - & - & - \\
\hline 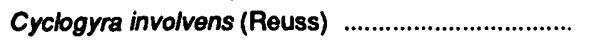 & 0.6 & - & - & - & $\cdot$ & - & - & - & $\cdot$ & $\cdot$ & - & - \\
\hline Dentalina frobisherensis Loeblich and Tappan ..... & - & - & - & - & - & - & - & - & $\cdot$ & - & - & - \\
\hline 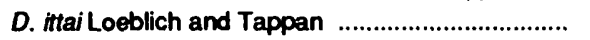 & - & - & - & - & - & - & - & - & - & - & - & - \\
\hline 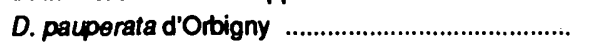 & - & 1.0 & $=$ & - & - & - & - & - & - & - & - & - \\
\hline 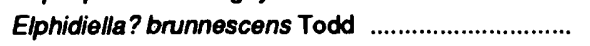 & - & - & - & - & - & - & - & - & - & - & - & - \\
\hline Elphidiella groenlandica (Cushman) .......................... & 1.3 & 11.5 & - & 4.3 & - & 1.0 & - & - & - & - & - & - \\
\hline 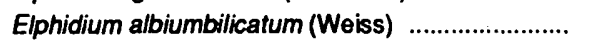 & - & 1.0 & - & - & - & $\cdot$ & - & - & 12.8 & - & - & - \\
\hline 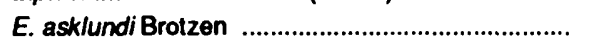 & - & - & - & - & - & - & - & - & - & - & - & - \\
\hline 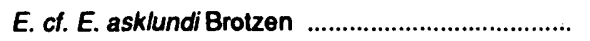 & 0.3 & 0.5 & - & - & - & - & - & - & $\cdot$ & - & - & - \\
\hline E. bartletti Cushman & 2.6 & 2.9 & $\cdot$ & 4.3 & - & - & 1.7 & - & - & - & - & - \\
\hline E. clavatum Cushman & 56.2 & 5.7 & 28.6 & 8.7 & 31.8 & 56.0 & 79.3 & 15.3 & 42.6 & 28.6 & 66.7 & 85.3 \\
\hline 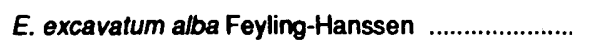 & 0.3 & 61.2 & 42.9 & 43.5 & 36.4 & 27.0 & 10.3 & - & 2.1 & - & - & - \\
\hline 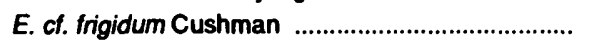 & - & - & - & - & - & - & - & - & - & - & - & - \\
\hline 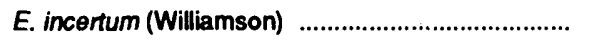 & 7.7 & 1.4 & - & - & - & - & - & - & - & - & :- & 2.3 \\
\hline E. nanum Vilks & 1.0 & - & - & - & - & - & - & - & 10.6 & - & - & · \\
\hline E. orbiculare (Brady) & 16.7 & 10.5 & 28.6 & 39.1 & 18.2 & 13.0 & 5.2 & 0.3 & - & - & - & - \\
\hline E. spp. . & - & - & - & - & - & - & - & - & $\cdot$ & - & - & - \\
\hline E. ustulatum Todd & - & - & - & $\cdot$ & - & - & - & - & - & - & - & - \\
\hline 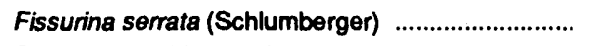 & - & - & - & $\cdot$ & - & - & $\cdot$ & $\cdot$ & - & - & - & - \\
\hline F. manginata (Montagu) & - & - & - & - & $\cdot$ & - & - & - & $\cdot$ & - & $\cdot$ & - \\
\hline 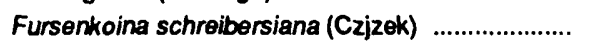 & - & - & - & - & - & - & - & - & - & - & - & - \\
\hline 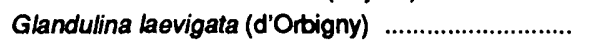 & - & - & - & - & - & - & - & - & - & - & - & - \\
\hline Globulina sp. & 0.6 & - & - & - & - & - & - & - & - & - & - & - \\
\hline 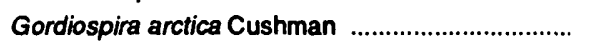 & - & - & - & - & - & - & - & - & - & - & - & - \\
\hline 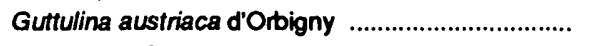 & - & $\cdot$ & - & $\cdot$ & - & - & - & - & $\cdot$ & - & - & $\cdot$ \\
\hline 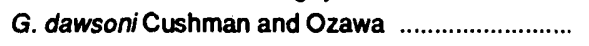 & 0.6 & - & - & - & - & - & - & - & - & - & - & - \\
\hline 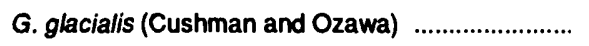 & 0.3 & - & - & - & - & - & - & - & - & - & - & - \\
\hline 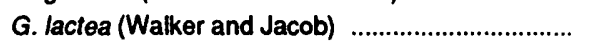 & 0.3 & 1.0 & - & - & - & 1.0 & - & 0.7 & - & 14.3 & - & - \\
\hline G. Sp. . & - & - & - & - & - & - & - & - & - & - & - & - \\
\hline 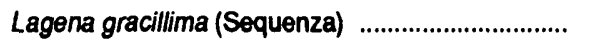 & - & - & - & - & - & - & - & - & - & - & $\cdot$ & - \\
\hline L. laevis (Montagu) & - & - & - & - & - & - & - & - & - & - & - & - \\
\hline 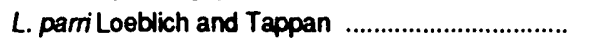 & - & - & - & - & - & - & - & - & $\cdot$ & - & - & - \\
\hline 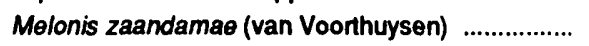 & - & - & - & - & - & - & - & - & - & - & - & - \\
\hline Miliolinella chukchiensis Loeblich and Tappan ..... & 1.9 & 0.5 & - & - & - & - & - & 78.6 & 23.4 & 42.9 & 33.3 & - \\
\hline 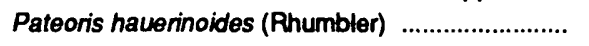 & - & - & - & $\cdot$ & - & - & - & 0.3 & - & - & - & - \\
\hline Parafissurina lateratis carinata (Buchner) ................. & - & - & - & - & - & - & - & - & - & - & - & - \\
\hline Polymorphina suboblonga (Cushman and Ozawa) & 1.6 & - & - & - & - & 2.0 & - & - & - & - & - & . \\
\hline 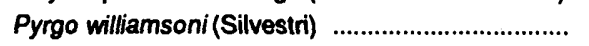 & - & - & - & - & - & - & - & - & - & - & - & - \\
\hline 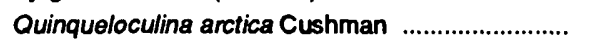 & - & 2.4 & $\cdot$ & - & - & - & - & - & - & - & - & . \\
\hline 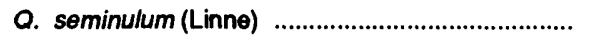 & 3.5 & - & - & - & - & - & - & 4.8 & 6.4 & - & - & - \\
\hline 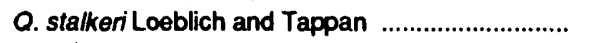 & - & - & - & - & - & - & - & - & 2.1 & - & - & - \\
\hline Scutuloris tegminis Loeblich and Tappan ............... & 0.0 & - & - & - & - & - & 1.7 & - & - & - & - & 2.3 \\
\hline Sigmomorphina sp. & - & - & - & - & - & - & - & - & $\cdot$ & - & - & - \\
\hline 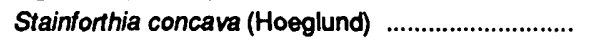 & - & - & - & - & - & - & - & - & - & - & - & - \\
\hline Triloculina trihedra Loeblich and Tappan ............... & - & $\cdot$ & - & - & - & - & - & - & $\cdot$ & - & - & - \\
\hline Foraminiferal number & 2489 & 209 & 7 & 23 & 22 & 100 & 58 & 294 & 47 & 7 & 3 & 43 \\
\hline Diversity & 19 & 13 & 3 & 5 & 6 & 6 & 6 & 6 & 7 & 4 & 2 & 3 \\
\hline
\end{tabular}


Sample number

\begin{tabular}{|c|c|c|c|c|c|c|c|c|c|c|c|c|c|c|c|c|}
\hline $18-18$ & $18-19$ & $18-20$ & $18-21$ & $18-22$ & $18-23$ & $18-24$ & $18-25$ & $18-26$ & $18-27$ & $18-28$ & $18-29$ & $18-30$ & $18-31$ & $18-34$ & $18-35$ & $18-37$ \\
\hline- & 2.1 & 0.6 & 2.4 & 1.9 & 2.1 & 1.9 & 5.5 & 6.1 & - & 3.5 & 10.4 & 7.5 & 6.0 & 16.4 & 5.6 & 1.8 \\
\hline - & - & - & - & - & - & - & 1.5 & 0.4 & - & 1.2 & 0.8 & 2.7 & 1.6 & 4.3 & - & 1.8 \\
\hline - & - & - & 0.4 & 0.2 & - & - & - & - & - & - & - & - & - & - & - & . \\
\hline - & 0.6 & 2.9 & 13.3 & 1.3 & 27.1 & 8.5 & 1.8 & 7.1 & - & 2.3 & 5.1 & 3.9 & 17.8 & 16.0 & 18.8 & 4.5 \\
\hline - & - & 1.4 & 11.9 & 9.8 & 3.8 & 10.4 & - & 30.8 & - & 0.8 & 12.2 & 7.7 & - & - & 0.7 & 0.9 \\
\hline - & - & - & - & - & - & - & - & - & - & - & - & - & - & - & . & . \\
\hline- & - & - & - & - & - & - & - & - & - & - & - & - & 0.1 & - & 0.7 & - \\
\hline- & - & - & - & - & - & - & - & 0.1 & - & - & - & - & - & - & - & . \\
\hline - & - & - & 0.2 & - & - & - & - & - & - & - & 0.3 & 0.4 & - & 0.3 & - & - \\
\hline - & - & - & - & - & - & 0.4 & - & - & - & - & - & - & - & - & - & - \\
\hline- & - & - & - & - & - & - & - & $:$ & - & - & - & - & - & 1.5 & 1.3 & . \\
\hline - & - & - & 0.2 & 6.6 & 0.6 & 3.4 & 0.3 & - & - & 0.6 & 0.5 & 1.3 & 2.3 & 1.9 & 1.3 & 3.6 \\
\hline - & - & - & - & 0.4 & 1.8 & 2.1 & - & 2.3 & 40.0 & 0.8 & 0.3 & 1.4 & 0.6 & - & - & . \\
\hline - & - & - & - & 4.9 & - & 0.6 & 0.9 & - & - & 1.8 & 0.5 & - & 0.1 & - & - & . \\
\hline- & - & - & - & - & - & - & - & - & . & - & - & - & - & - & - & . \\
\hline - & - & - & 0.6 & 0.2 & 4.4 & 5.5 & 11.9 & 0.3 & - & 10.3 & 6.9 & 8.6 & 1.6 & 1.2 & 0.3 & . \\
\hline 98.1 & 85.3 & 72.4 & 41.0 & 43.5 & 21.8 & 22.6 & 33.4 & 9.8 & - & 26.7 & 25.7 & 33.8 & 21.7 & 9.6 & 24.0 & 35.7 \\
\hline - & - & - & 1.6 & - & - & 0.9 & - & 0.1 & - & 0.4 & - & 0.2 & 1.0 & - & - & 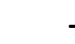 \\
\hline - & - & - & - & - & - & - & - & - & - & - & - & - & 1.5 & 0.9 & - & . \\
\hline- & 0.6 & 1.8 & 10.1 & 15.9 & 16.5 & 19.6 & 29.5 & 16.0 & 20.0 & 34.9 & 5.3 & - & 6.7 & - & 2.3 & 2.7 \\
\hline - & 5.1 & 10.8 & 3.0 & 0.4 & 0.9 & 0.6 & - & 1.0 & - & - & 3.1 & 1.8 & 1.9 & 2.2 & - & . \\
\hline- & 5.1 & 7.6 & 12.3 & 12.7 & 12.6 & 17.7 & 10.6 & 21.7 & 20.0 & 13.1 & 9.2 & 16.6 & 13.8 & 20.7 & 20.7 & 8.9 \\
\hline - & 0.3 & - & 0.2 & 1.5 & 2.9 & 1.3 & 3.6 & 0.6 & 20.0 & 2.7 & 2.3 & 1.3 & 1.2 & 5.2 & 0.7 & - \\
\hline- & - & - & - & - & - & - & - & - & - & - & 5.6 & 9.5 & 7.0 & 5.6 & 5.3 & 0.9 \\
\hline- & - & - & - & - & - & - & - & - & - & - & 0.3 & 0.2 & - & - & - & - \\
\hline - & - & - & - & - & - & 0.4 & - & - & - & - & - & 0.2 & 0.1 & 0.3 & 0.3 & - \\
\hline- & - & - & - & - & 1.5 & - & - & - & - & - & 1.5 & - & - & - & - & - \\
\hline - & - & - & - & 0.2 & - & - & - & - & - & - & - & - & - & - & - & . \\
\hline- & - & - & - & - & - & - & - & - & - & - & 0.3 & - & - & - & - & - \\
\hline - & - & - & - & - & - & - & - & - & - & - & - & - & 2.6 & - & 1.3 & - \\
\hline- & - & - & - & - & - & 0.4 & - & 0.3 & - & $\cdot$ & - & - & - & 0.6 & 0.3 & 1.8 \\
\hline- & 0.6 & - & 0.4 & - & 0.3 & 0.6 & - & - & - & - & 2.8 & - & 0.1 & - & - & - \\
\hline - & - & 0.2 & - & - & - & 1.5 & - & - & - & - & - & - & - & 8.0 & - & - \\
\hline- & - & 0.4 & 1.0 & 0.4 & 0.6 & 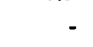 & 0.3 & 0.7 & - & 0.8 & 2.5 & 1.4 & 6.8 & - & 7.9 & 1.8 \\
\hline - & - & - & - & - & - & - & - & - & - & - & - & - & - & 0.9 & - & - \\
\hline- & - & - & - & - & - & - & - & 0.1 & - & - & - & - & - & - & - & - \\
\hline- & - & - & - & - & - & - & - & - & - & - & - & - & 0.6 & 0.6 & - & - \\
\hline - & - & - & - & - & - & - & . & 0.1 & - & - & 0.8 & - & 0.1 & - & 0.3 & . \\
\hline - & - & - & - & - & - & - & - & - & - & - & 1.5 & 1.1 & 0.3 & 1.5 & - & . \\
\hline- & - & - & 0.8 & - & - & - & - & - & - & - & - & - & - & - & 1.6 & - \\
\hline- & - & - & - & - & - & - & - & - & - & - & - & - & 1.5 & 1.5 & 0.3 & - \\
\hline- & - & - & - & - & - & - & - & 0.1 & - & - & - & - & - & - & - & - \\
\hline - & - & 1.0 & - & - & - & . & 0.3 & - & - & - & - & - & - & - & - & . \\
\hline- & - & - & - & - & - & - & - & - & - & - & - & - & 0.1 & 0.3 & 0.3 & - \\
\hline - & - & - & 0.2 & - & - & 0.2 & - & 0.1 & - & - & 1.3 & - & - & 0.3 & 5.9 & . \\
\hline - & - & 0.4 & 0.2 & - & 0.3 & - & 0.3 & - & - & 0.2 & 1.0 & 0.4 & 2.3 & - & - & 34.8 \\
\hline - & - & - & - & - & - & - & - & - & - & - & . & - & - & - & - & - \\
\hline 1.9 & - & 0.2 & - & - & - & - & - & - & - & - & - & 0.2 & 0.3 & - & - & 0.9 \\
\hline- & - & - & $\cdot$ & - & - & - & - & - & - & - & - & - & 0.1 & - & - & - \\
\hline- & - & 0.2 & - & - & 2.9 & 1.1 & - & 2.0 & - & - & - & - & - & - & - & - \\
\hline- & 0.3 & - & - & $\cdot$ & - & $\cdot$ & $\cdot$ & - & - & $\cdot$ & - & - & - & - & - & - \\
\hline 216 & 1332 & 1960 & 3960 & 3768 & 10880 & 1876 & 5264 & 1384 & 5 & 513 & 3144 & 4472 & 687 & 1296 & 304 & 112 \\
\hline 2 & 9 & 13 & 18 & 15 & 16 & 20 & 13 & 20 & 4 & 15 & 24 & 20 & 28 & 22 & 21 & 13 \\
\hline
\end{tabular}


Table 18. Borehole HLA 19, benthic foraminifers distribution and abundance, Beaufort Sea shelf, Alaska.

[Abundance of each species is a percentage of the total foraminifer species in $100 \mathrm{~g}$ of sediment. Foraminiferal number is the number of specimens per

\begin{tabular}{|c|c|c|c|c|c|c|c|c|c|}
\hline \multirow[t]{2}{*}{ Taxa } & \multicolumn{9}{|c|}{ Sample number } \\
\hline & $19 \cdot 1$ & $19-2$ & $19-3$ & $19-4$ & $19-5$ & $19-6$ & $19-7$ & $19-8$ & $19-9$ \\
\hline Astacolus hyalacrulus Loeblich and Tappan .......... & . & - & - & - & - & - & - & - & - \\
\hline Astrononion gallowayi Looblich and Tappan ......... & - & - & - & - & - & - & - & - & - \\
\hline 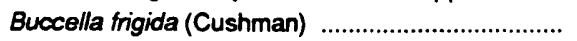 & 12.0 & 8.7 & 11.6 & 2.1 & 7.2 & 0.5 & - & 2.2 & - \\
\hline 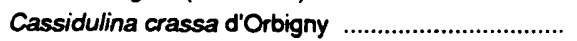 & - & - & $\cdot$ & - & $\cdot$ & - & - & - & - \\
\hline C. islandica Norvang & - & 0.3 & - & 1.0 & 1.3 & 0.9 & - & 0.6 & - \\
\hline C. norcrossi Cushman & 0.3 & - & - & 0.3 & 0.4 & 0.5 & - & - & . \\
\hline Cibicides sp. & - & - & - & - & 0.4 & $\cdot$ & - & $\cdot$ & : \\
\hline Dentalina ittai Loeblich and Tappan ........................... & - & - & - & - & $\cdot$ & - & - & - & - \\
\hline Discorbis baccata (Heron-Allen and Earland) ........ & 0.3 & 1.0 & - & - & 0.4 & - & - & - & - \\
\hline 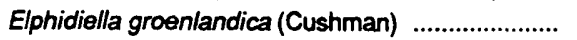 & - & 0.3 & - & - & - & 0.9 & - & - & - \\
\hline Elphidium albiumbilicatum (Weiss) ........................... & - & . & - & 8.9 & 3.0 & 2.8 & - & 13.0 & - \\
\hline 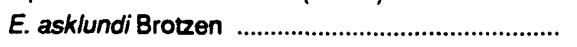 & - & - & - & - & 0.4 & 0.5 & - & - & - \\
\hline 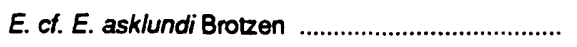 & 0.3 & - & - & - & - & $\cdot$ & - & - & - \\
\hline E. bartetti Cushman & $\cdot$ & - & - & 1.7 & 0.6 & - & - & - & - \\
\hline E. clavatum Cushman & 18.7 & 20.6 & 7.2 & - & 2.3 & 13.4 & 96.4 & 1.2 & 100.0 \\
\hline 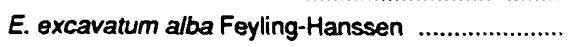 & 48.1 & 43.2 & 46.9 & 35.7 & 26.1 & - & 3.0 & 0.3 & - \\
\hline 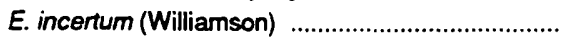 & - & - & - & - & - & 1.4 & - & - & - \\
\hline 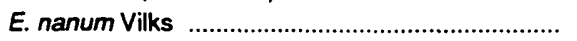 & - & - & - & - & - & - & - & - & - \\
\hline E. orbiculare (Brady) & 16.5 & 25.1 & 32.9 & 48.5 & 56.7 & 75.9 & 0.6 & 82.4 & - \\
\hline E. spp. & - & - & - & - & - & - & - & - & . \\
\hline 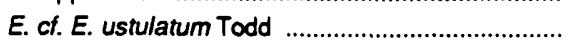 & - & - & - & - & - & - & - & - & - \\
\hline 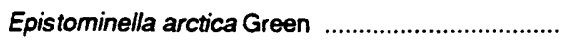 & - & - & $\cdot$ & $\cdot$ & - & $\cdot$ & - & - & - \\
\hline 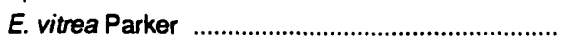 & - & - & - & - & - & - & - & - & - \\
\hline 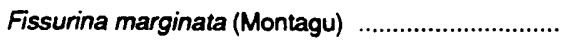 & - & - & - & - & - & - & - & $\cdot$ & - \\
\hline F. spp. . & - & - & - & - & - & - & - & - & - \\
\hline 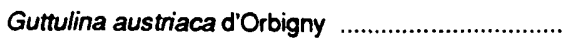 & 0.6 & . & 0.7 & 0.3 & 0.4 & 0.9 & - & 0.3 & - \\
\hline 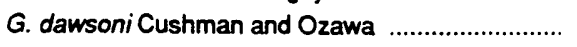 & 1.9 & - & - & - & - & - & - & - & - \\
\hline 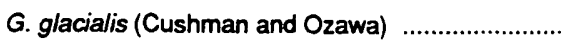 & - & - & - & - & - & - & - & $\cdot$ & - \\
\hline 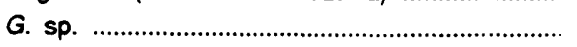 & 0.3 & - & - & - & - & - & - & - & - \\
\hline 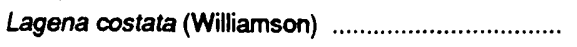 & - & - & - & $\cdot$ & $\cdot$ & $\cdot$ & - & - & - \\
\hline 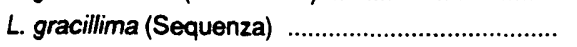 & - & . & - & - & . & - & - & - & - \\
\hline 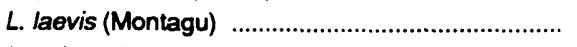 & - & - & - & - & $\cdot$ & - & - & - & - \\
\hline 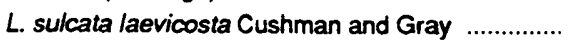 & - & . & - & - & - & - & - & - & - \\
\hline Miliolinella chukchiensis Loeblich and Tappan ..... & - & - & $\therefore$ & - & - & - & - & . & - \\
\hline Nonionella auricula Heron-Allen and Earland ........ & - & . & - & $\cdot$ & - & - & - & - & - \\
\hline Nodosaria spp. & - & - & - & - & - & - & - & - & - \\
\hline 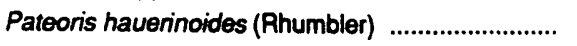 & - & - & - & $\cdot$ & - & 0.9 & - & - & - \\
\hline Parafissurina tectulostoma Loeblich and Tappan . & - & - & - & - & . & - & - & - & - \\
\hline Polymorphina suboblonga (Cushman and Ozawa) & - & - & - & - & - & - & - & - & - \\
\hline P. spp. & 0.3 & 0.7 & 0.7 & 1.4 & 0.6 & 0.5 & - & - & - \\
\hline 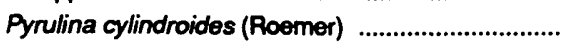 & - & - & - & - & - & - & - & - & - \\
\hline 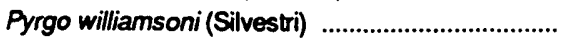 & - & - & - & - & - & 0.5 & - & $\cdot$ & $\cdot$ \\
\hline 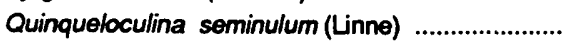 & - & - & - & - & - & - & - & - & - \\
\hline 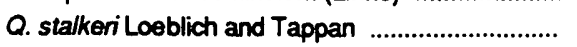 & 0.6 & - & - & - & - & - & - & - & - \\
\hline Scutuloris tegminis Loeblich and Tappan ............. & - & - & - & - & - & - & - & - & - \\
\hline 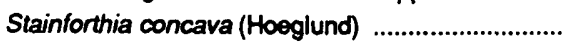 & - & - & - & - & - & 0.5 & - & - & - \\
\hline Triloculina trihedra Loeblich and Tappan ................. & $\cdot$ & $\cdot$ & - & - & - & $\cdot$ & - & $\cdot$ & $\cdot$ \\
\hline Foraminiferal number & 2528 & 4592 & 2336 & 582 & 471 & 432 & 168 & 648 & 17 \\
\hline Diversity & 12 & 8 & 6 & 9 & 13 & 14 & 3 & 7 & 1 \\
\hline
\end{tabular}


$100 \mathrm{~g}$ of sediment, and diversity is the number of species per sample]

\begin{tabular}{|c|c|c|c|c|c|c|c|c|}
\hline \multicolumn{9}{|c|}{ Sample number } \\
\hline $19-10$ & $19-11$ & $19-12$ & $19-13$ & $19-14$ & $19-15$ & $19-16$ & $19-17$ & $19-18$ \\
\hline - & - & Q.3 & - & - & - & . & - & - \\
\hline - & - & 1.0 & - & - & - & - & - & - \\
\hline- & 6.2 & 9.2 & 1.5 & 1.8 & 0.2 & - & 4.0 & 6.8 \\
\hline - & - & 0.3 & - & - & - & - & - & - \\
\hline - & 2.2 & 10.5 & 8.4 & 5.9 & 0.2 & - & 17.7 & 17.6 \\
\hline- & 1.0 & 22.5 & 0.4 & 0.7 & - & - & 16.8 & 21.8 \\
\hline - & - & - & - & - & - & - & - & - \\
\hline- & - & - & - & - & . & - & 0.2 & 0.6 \\
\hline- & - & 1.9 & - & - & - & - & 0.7 & 1.7 \\
\hline- & 1.0 & - & 0.8 & 0.4 & 0.5 & 0.3 & 0.4 & - \\
\hline - & - & 1.0 & - & - & - & - & - & 0.6 \\
\hline - & 0.2 & 0.3 & - & - & - & - & 1.3 & - \\
\hline - & - & - & - & - & - & - & - & - \\
\hline - & - & - & . & - & . & - & 2.4 & 0.6 \\
\hline 33.3 & 51.1 & 19.7 & 35.7 & 46.7 & 37.6 & 23.4 & 17.3 & 6.8 \\
\hline - & - & - & 3.8 & 0.7 & 0.7 & 4.6 & 2.2 & 1.4 \\
\hline - & 7.0 & . & 4.9 & 3.3 & - & 5.4 & 9.7 & 8.2 \\
\hline - & 19.0 & - & 12.2 & - & - & 5.2 & - & - \\
\hline - & 10.5 & 30.5 & 18.3 & 38.2 & 60.0 & 55.7 & 24.3 & 31.7 \\
\hline . & - & 0.3 & - & - & - & - & - & - \\
\hline - & - & - & 8.0 & - & - & 4.1 & - & . \\
\hline - & - & 0.3 & - & - & - & - & - & - \\
\hline - & - & 0.6 & - & - & - & - & - & $\cdot$ \\
\hline . & - & - & - & - & - & - & 0.2 & 0.3 \\
\hline - & - & 0.3 & - & - & - & - & - & - \\
\hline 33.3 & . & - & - & 0.4 & 0.4 & - & 1.8 & 0.8 \\
\hline - & - & $\cdot$ & - & - & . & . & - & - \\
\hline - & - & - & 0.8 & - & - & - & - & - \\
\hline- & - & 0.3 & 0.4 & - & - & - & - & - \\
\hline - & - & $\cdot$ & - & - & - & - & 0.2 & - \\
\hline- & - & 0.3 & 0.4 & - & - & - & - & - \\
\hline$\cdot$ & 0.2 & $\cdot$ & - & - & - & - & - & - \\
\hline$\cdot$ & 0.2 & - & - & - & • & * & - & $\cdot$ \\
\hline$\cdot$ & - & $\because$ & - & 0.4 & - & - & 0.2 & 0.3 \\
\hline - & $\cdot$ & $0.3^{\circ}$ & - & - & - & - & - & - \\
\hline - & - & - & - & - & - & - & - & 0.3 \\
\hline . & . & - & - & . & - & - & 0.2 & - \\
\hline - & 0.2 & - & - & - & - & - & - & - \\
\hline - & 0.5 & . & 1.1 & - & - & 0.5 & . & - \\
\hline 33.3 & - & - & - & - & - & - & - & 0.3 \\
\hline$\cdot$ & 0.5 & 0.3 & 1.9 & - & - & - & - & - \\
\hline - & - & - & - & - & $\cdot$ & - & - & - \\
\hline - & $\cdot$ & - & - & - & - & - & 0.2 & - \\
\hline$\cdot$ & $\cdot$ & - & $\cdot$ & - & - & - & - & - \\
\hline - & - & - & 0.4 & - & 0.4 & 0.8 & - & - \\
\hline$\cdot$ & $\cdot$ & - & 1.1 & 1.1 & - & - & - & 0.3 \\
\hline - & - & - & - & 0.4 & - & - & - & - \\
\hline 3 & 3208 & 2520 & 1052 & 17408 & 8800 & 2944 & 1808 & 2824 \\
\hline 3 & 14 & 19 & 17 & 12 & 8 & 9 & 18 & 17 \\
\hline
\end{tabular}


Table 19. Borehole HLA 20, benthic foraminifers distribution and abundance, Beaufort Sea shelf, Alaska.

[Abundance of each species is a percentage of the total foraminifer species in $100 \mathrm{~g}$ of sediment. Foraminiferal number is the number of

\begin{tabular}{|c|c|c|c|c|c|c|c|c|}
\hline \multirow{2}{*}{ Taxa } & \multicolumn{8}{|c|}{ Sample number } \\
\hline & $20-1$ & $20-2$ & 20-3 & $20-4$ & $20-5$ & $20-6$ & $20-7$ & 20-8 \\
\hline Astrononion gallowayi Loeblich and Tappan ......... & $\cdot$ & - & - & - & - & - & - & - \\
\hline 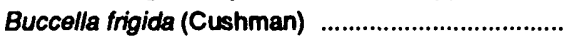 & 1.5 & 1.3 & - & 7.5 & 2.1 & 4.2 & 1.6 & 5.0 \\
\hline 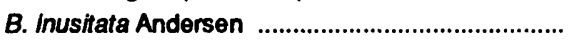 & - & - & - & 1.3 & - & - & - & - \\
\hline 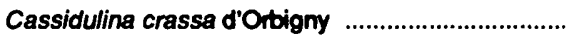 & - & - & - & - & - & - & - & - \\
\hline 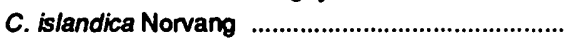 & 4.4 & 6.5 & 10.3 & 17.5 & 2.4 & 22.7 & 21.5 & 20.8 \\
\hline 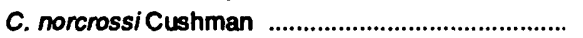 & 0.7 & 2.3 & 5.7 & 12.2 & 2.1 & 2.3 & 2.2 & 1.2 \\
\hline Cibicides lobatulus (Waker and Jacob) ................. & - & - & $\cdot$ & - & - & - & - & - \\
\hline 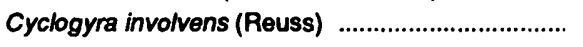 & - & 0.6 & $\cdot$ & - & 0.3 & - & 0.3 & $\cdot$ \\
\hline Dentalina ittai Loeblich and Tappan ........................ & - & - & - & - & - & 0.1 & - & - \\
\hline D. spp. & - & - & 0.2 & - & - & - & - & - \\
\hline Discorbis baccata (Heron-Allen and Earland) ....... & - & - & $\cdot$ & 0.4 & - & 3.7 & 3.0 & 1.6 \\
\hline Elphidiella groenlandica (Cushman) ..................... & 0.4 & - & 0.7 & - & 0.7 & 0.3 & - & 0.3 \\
\hline Elphidium albiumbilicatum (Weiss) ...................... & - & - & 0.5 & 1.1 & - & - & 0.5 & - \\
\hline 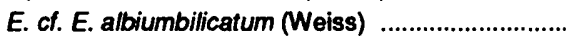 & - & - & - & - & - & - & - & - \\
\hline 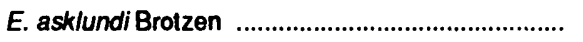 & - & - & 1.7 & 0.2 & - & - & 0.3 & - \\
\hline 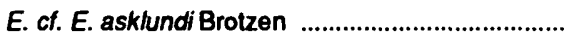 & - & $\cdot$ & 0.2 & - & - & - & - & - \\
\hline 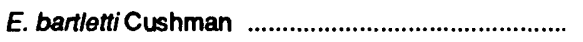 & - & - & 8.4 & 2.1 & 1.4 & 2.2 & 0.8 & 1.9 \\
\hline 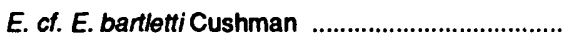 & 0.2 & - & - & - & - & - & - & - \\
\hline 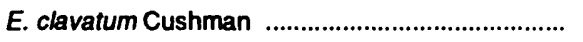 & 61.8 & 46.3 & 23.2 & 37.0 & 59.6 & 43.9 & 45.7 & 42.2 \\
\hline E. excavatum alba Feyling-Hanssen .......................... & 2.9 & - & 4.2 & 0.6 & 3.4 & - & $\cdot$ & - \\
\hline 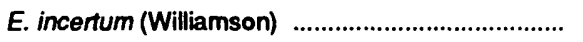 & 3.5 & 13.9 & 4.2 & - & 1.4 & 1.0 & 0.3 & 1.9 \\
\hline E. nanum Vilks & 6.4 & 0.3 & - & 1.5 & 5.5 & 9.4 & 15.5 & 12.7 \\
\hline 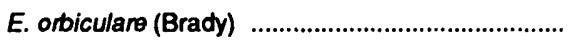 & 14.3 & 10.7 & 38.2 & 16.0 & 16.1 & 5.6 & 4.9 & 7.5 \\
\hline 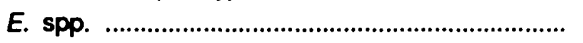 & - & - & - & - & - & - & - & - \\
\hline 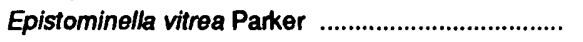 & - & - & - & - & - & 0.1 & 0.5 & 1.6 \\
\hline 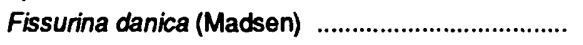 & - & - & - & 0.2 & - & 0.6 & - & 0.3 \\
\hline 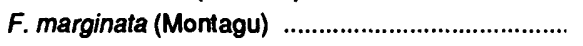 & - & 0.3 & - & - & - & 0.1 & - & - \\
\hline 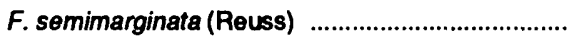 & - & 0.3 & - & 0.2 & - & - & - & - \\
\hline 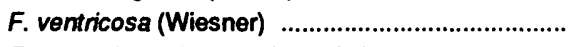 & - & - & - & - & - & - & - & - \\
\hline Fursenkoina schreibersiana (Czjzek) ...................... & - & 1.0 & 0.2 & 0.6 & $\cdot$ & 0.4 & 0.8 & 0.6 \\
\hline 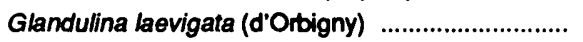 & - & 5.5 & 0.2 & 0.2 & - & 0.4 & - & 0.3 \\
\hline 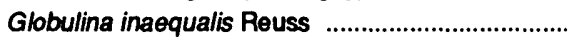 & 0.2 & - & - & - & - & - & - & - \\
\hline G. sp. & - & - & - & - & - & 0.1 & - & - \\
\hline Gordiospira arctica Cushman .................................... & - & - & $\cdot$ & - & 0.7 & - & - & - \\
\hline Guttulina dawsoni Cushman and Ozawa .............. & - & - & - & - & - & - & - & - \\
\hline G. glacialis (Cushman and Ozawa) ........................... & 0.2 & 2.9 & 0.5 & - & 0.3 & 0.4 & 0.5 & 0.9 \\
\hline 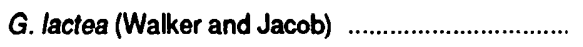 & - & - & - & 0.2 & - & - & - & - \\
\hline 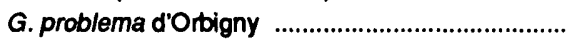 & - & - & - & - & - & - & - & - \\
\hline 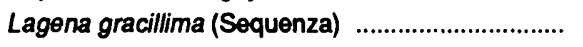 & - & 0.3 & - & - & - & - & - & - \\
\hline 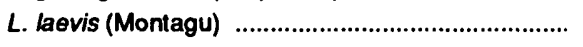 & $\cdot$ & - & - & - & 0.3 & - & - & - \\
\hline L. sp. & - & - & - & - & - & - & 0.3 & - \\
\hline Miliolinella chukchiensis Loeblich and Tappan ..... & - & 0.3 & - & - & - & - & - & - \\
\hline Nonionella labradorica (Dawson) ............................... & - & $\because$ & - & - & - & - & - & - \\
\hline Nonion sp. & - & - & - & - & - & - & - & - \\
\hline 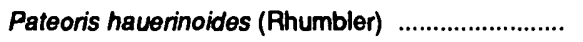 & - & 0.3 & - & - & 0.7 & 0.1 & - & - \\
\hline Parafissurina tectubstoma Loeblich and Tappan . & - & - & - & - & - & 0.1 & - & - \\
\hline Polymorphina suboblonga (Cushman and Ozawa) & - & - & - & - & 0.7 & - & - & - \\
\hline Pseudopolymorphina norvangliae (Cushman) ...... & - & - & - & - & - & - & - & - \\
\hline Pyrulina cylindroides (Roemer) ................................. & - & - & 0.7 & 0.2 & - & - & - & 0.6 \\
\hline 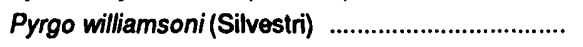 & - & - & - & 0.2 & - & 0.1 & - & - \\
\hline 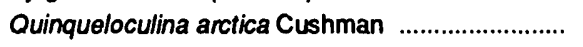 & - & 5.2 & 0.2 & - & 0.3 & 0.1 & - & 0.3 \\
\hline 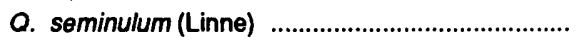 & 1.3 & 0.3 & - & $\cdot$ & 0.7 & 0.1 & - & - \\
\hline Scutuloris tegminis Loeblich and Tappan ............. & 2.0 & 1.3 & - & - & 1.4 & - & - & - \\
\hline 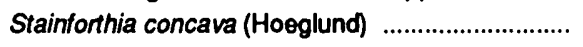 & - & - & 0.5 & 0.2 & - & 0.3 & 0.8 & 0.3 \\
\hline Triloculina trihedra Loeblich and Tappan .............. & 0.2 & 0.3 & - & 0.4 & - & 1.3 & 0.5 & - \\
\hline Foraminiferal number & 1820 & 1236 & 25984 & 14976 & 4672 & 5472 & 23552 & 10304 \\
\hline Diversity & 15 & 20 & 18 & 21 & 19 & 25 & 18 & 18 \\
\hline
\end{tabular}


specimens per $100 \mathrm{~g}$ of sediment, and diversity is the number of species per sample]

\begin{tabular}{|c|c|c|c|c|c|c|c|c|}
\hline \multicolumn{9}{|c|}{ Sample number } \\
\hline $20-9$ & $20-10$ & $20-11$ & $20-12$ & $20-13$ & $20-14$ & $20-15$ & $20-16$ & $20-17$ \\
\hline - & - & 1.0 & $\cdot$ & - & - & - & - & - \\
\hline 2.9 & 5.5 & 5.3 & 3.4 & 0.3 & 4.5 & 2.7 & 0.9 & 7.6 \\
\hline- & - & - & - & - & - & - & - & - \\
\hline - & - & - & - & - & - & - & - & 0.7 \\
\hline 40.9 & 2.0 & 18.8 & 24.1 & 11.1 & 26.1 & 34.0 & 6.0 & 12.5 \\
\hline 4.2 & 3.3 & 10.4 & 48.3 & 73.7 & 8.0 & - & 1.5 & 15.2 \\
\hline - & - & 0.3 & - & - & - & - & - & - \\
\hline - & - & - & - & - & - & - & - & - \\
\hline- & - & - & - & - & - & - & - & - \\
\hline- & - & - & - & 0.3 & - & - & - & - \\
\hline - & - & - & - & - & - & 1.5 & 0.1 & - \\
\hline - & 0.7 & 0.3 & - & - & - & - & 0.1 & - \\
\hline- & 0.7 & - & - & - & 0.2 & - & - & 1.7 \\
\hline- & - & 0.8 & - & - & - & - & - & - \\
\hline- & 0.7 & 1.8 & . & - & - & - & 0.3 & 0.5 \\
\hline - & - & - & - & - & - & - & - & - \\
\hline 1.0 & 0.3 & 2.5 & - & - & 1.4 & 0.5 & - & 2.0 \\
\hline- & - & - & - & - & - & - & $\cdot$ & - \\
\hline 36.1 & 56.4 & 28.7 & 20.7 & 4.7 & 37.6 & 33.7 & 38.6 & 20.8 \\
\hline- & 0.7 & 0.5 & - & : & 0.7 & - & 0.7 & 2.5 \\
\hline 1.0 & 2.6 & 5.8 & 3.4 & 0.6 & 7.1 & 3.0 & 18.6 & 16.7 \\
\hline 3.2 & 2.3 & 1.5 & - & - & 4.5 & 12.4 & 13.5 & 2.9 \\
\hline 7.7 & 21.8 & 19.3 & - & 1.6 & 4.0 & 6.5 & 14.4 & 14.2 \\
\hline- & - & - & - & - & - & 0.5 & - & - \\
\hline$\cdot$ & - & - & - & - & 0.2 & - & 1.0 & . \\
\hline- & 0.3 & - & - & - & - & - & - & - \\
\hline - & - & - & - & - & 0.2 & - & - & - \\
\hline- & - & - & - & - & - & - & - & - \\
\hline- & - & 0.3 & - & - & - & - & - & . \\
\hline- & - & 0.3 & - & 7.3 & 1.4 & 0.2 & 0.1 & 1.0 \\
\hline- & - & - & - & - & - & - & - & - \\
\hline - & 0.7 & - & - & - & - & - & 0.9 & - \\
\hline$\cdot$ & $\cdot$ & - & - & - & - & - & $\cdot$ & - \\
\hline - & - & - & - & - & - & - & - & - \\
\hline - & - & - & - & - & - & - & 0.3 & 0.5 \\
\hline 2.6 & 2.0 & 1.3 & - & 0.3 & 0.5 & 0.5 & 1.0 & 1.0 \\
\hline - & - & - & - & - & - & - & $\cdot$ & - \\
\hline - & - & - & - & - & - & - & 0.1 & - \\
\hline- & - & 0.3 & - & - & - & - & - & - \\
\hline - & - & - & - & - & - & - & - & - \\
\hline - & 0.3 & - & - & - & - & - & - & 0.2 \\
\hline- & - & - & - & - & - & - & - & - \\
\hline - & - & 0.3 & - & - & - & - & - & - \\
\hline- & - & 0.3 & - & - & - & - & - & - \\
\hline - & $\cdot$ & - & - & - & - & 0.7 & 0.1 & - \\
\hline- & - & - & - & - & 0.9 & - & - & - \\
\hline- & - & 0.3 & - & - & - & 0.2 & 0.1 & - \\
\hline- & - & - & $\cdot$ & $\cdot$ & - & 0.2 & - & - \\
\hline - & - & - & - & - & - & - & 0.4 & - \\
\hline - & - & - & - & - & - & 0.2 & - & - \\
\hline 0.3 & - & $\cdot$ & - & - & - & - & - & - \\
\hline - & - & - & - & - & - & - & - & - \\
\hline- & - & - & - & - & - & - & - & - \\
\hline- & - & - & - & - & 2.6 & 1.7 & 1.0 & - \\
\hline 0.3 & - & 0.3 & - & - & - & 1.2 & - & - \\
\hline 626 & 2456 & 3152 & 29 & 632 & 13600 & 6448 & 10992 & 13056 \\
\hline 11 & 16 & 22 & 5 & 9 & 16 & 17 & 21 & 16 \\
\hline
\end{tabular}




\section{APPENDIX 1. REGISTER OF MICROFOSSIL LOCALITIES, BEAUFORT SEA SHELF, ALASKA}

[Field number reflects depth (in feet) of sample below mudline (sediment-water interface). Comments indicate those samples that contain foraminifers (F), or ostracodes ( $O$ ); those that are barren (B) of either or both; and those that were not examined (nx) for either or both.]

\begin{tabular}{llccc}
\hline Sample & Weight & Field No. & Depth (meters) & Comments \\
\cline { 3 - 4 } No. & (grams) & $\begin{array}{c}\text { (=depth } \\
\text { in feet) }\end{array}$ & $\begin{array}{c}\text { Below } \\
\text { mudline }\end{array}$ & $\begin{array}{c}\text { Below sea level } \\
\text { (at base) }\end{array}$
\end{tabular}

Borehole HLA 3 (Mf5720)

Latitude $70^{\circ} 31^{\prime} 54.48^{\prime \prime} \mathrm{N}$. Longitude $148^{\circ} 53^{\prime} 53.50^{\prime \prime} \mathrm{W}$. Sea ice $1.9 \mathrm{~m}$ thick Mudline $13.5 \mathrm{~m}$ below sea level Total depth $42.8 \mathrm{mbelow}$ sea level

\begin{tabular}{rrrcrl}
\hline $3-1 \ldots \ldots$ & 25 & 5.5 & 1.7 & 15.2 & F, O \\
$3-2 \ldots \ldots$. & 50 & 10.5 & 3.2 & 16.7 & F, O \\
$3-3 \ldots \ldots$. & 100 & $15.0-17.0$ & $4.6-5.2$ & 18.7 & F, O
\end{tabular}

Borehole HLA 4 (Mf5721)

Latitude: $70^{\circ} 30^{\prime} 16.33^{\prime \prime} \mathrm{N}$. Longitude $148^{\circ} 22^{\prime} 42.92^{\prime \prime} \mathrm{W}$. Sea ice $1.5 \mathrm{~m}$ thick Mudline $8.5 \mathrm{~m}$ below sea level $\quad$ Total depth $39.4 \mathrm{mbelow}$ sealevel

\begin{tabular}{rrcccc}
\hline $4-1 \ldots \ldots$ & 100 & 4.5 & 1.4 & 9.9 & F, O \\
$4-2 \ldots \ldots$. & 100 & $9.5-11.0$ & $2.9-3.4$ & 11.3 & F, O \\
$4-3 \ldots \ldots$. & 100 & 13.5 & 4.1 & 12.6 & F, O \\
$4-4 \ldots \ldots$. & 100 & 13.9 & 4.2 & 12.7 & F, O \\
$4-5 \ldots \ldots$. & 50 & 18.8 & 5.7 & 14.2 & F, O \\
$4-6 \ldots .$. & 100 & $19.2-20.0$ & $5.9-6.1$ & 14.5 & F, O \\
$4-7 \ldots \ldots$. & 100 & $21.5-21.6$ & 6.6 & 15.0 & F, O \\
$4-8 \ldots .$. & 100 & $22.0-22.1$ & 6.7 & 15.2 & F, O \\
$4-9 \ldots \ldots$. & 50 & $23.3-23.4$ & 7.1 & 15.6 & F, O \\
$4-10 \ldots .$. & 100 & $24.4-24.5$ & $7.4-7.5$ & 16.0 & F, O \\
$4-10 . .$. & 100 & 26.0 & 8.0 & 16.5 & nxF, nxO \\
$4-10 B .$. & 100 & 28.0 & 8.6 & 17.1 & nxF, nxO \\
$4-11 \ldots .$. & 100 & $35.5-35.6$ & 10.8 & 19.3 & F, O \\
$4-12 \ldots .$. & 100 & 37.0 & 11.3 & 19.8 & F, O \\
$4-13 \ldots .$. & 50 & $38.1-38.2$ & 11.6 & 20.1 & F, O \\
$4-14 \ldots .$. & 50 & 40.0 & 12.2 & 20.7 & F, O \\
$4-15 \ldots . .$. & 100 & $40.5-41.1$ & $12.3-12.5$ & 21.0 & F, O \\
$4-16 \ldots .$. & 50 & $45.0-46.5$ & $13.7-14.2$ & 22.7 & F, O
\end{tabular}

\section{Borehole HLA 5 (Mf5722)}

Latitude $70^{\circ} 30^{\prime} 41.05^{\prime \prime} \mathrm{N}$. Longitude $148^{\circ} 37^{\prime} 49.53^{\prime \prime} \mathrm{W}$. Sea ice $1.4 \mathrm{~m}$ thick Mudline $12.8 \mathrm{~m}$ below sea level Total depth 104.2 mbelow sea level

\begin{tabular}{rrcccc}
\hline $5-1 \ldots \ldots$. & 100 & $3.0-5.0$ & $0.9-1.5$ & 14.3 & F, O \\
$5-2 \ldots \ldots$. & 50 & $7.5-10.0$ & $2.3-3.1$ & 15.9 & F, O \\
$5-3 \ldots \ldots$. & 100 & $15.0-16.5$ & $4.6-5.0$ & 17.0 & F, O \\
$5-4 \ldots \ldots$. & 100 & $58.5-60.0$ & $7.8-18.3$ & 30.3 & B \\
$5-5 \ldots \ldots$. & 100 & $118.5-120.0$ & $36.1-36.6$ & 48.6 & B \\
$5-6 \ldots .$. & 100 & $200.0-200.5$ & 61.0 & 73.9 & B \\
$5-7 \ldots \ldots$. & 50 & 219.5 & 66.9 & 79.7 & B \\
$5-8 \ldots \ldots$. & 100 & $239.5-240.0$ & $73.0-73.2$ & 86.0 & O, BF \\
\end{tabular}

\section{Borehole HLA 6 (Mf5723)}

Latitude $70^{\circ} 29^{\prime} 35.37^{\prime \prime} \mathrm{N}$. Longitude $148^{\circ} 07^{\prime} 42.51^{\prime \prime} \mathrm{W}$. Sea ice $1.4 \mathrm{~m}$ thick Mudline $11.1 \mathrm{~m}$ below sea level Total depth $42.3 \mathrm{~m}$ below sea level

\begin{tabular}{rrrrrc}
\hline $6-1 \ldots \ldots$. & 100 & 3.6 & 1.1 & 12.2 & F, O \\
$6-2 \ldots \ldots$. & 100 & 4.1 & 1.3 & 12.4 & F, O \\
$6-3 \ldots \ldots$. & 50 & 10.0 & 3.1 & 14.2 & F, nxO \\
$6-4 \ldots \ldots$. & 50 & 13.5 & 4.1 & 15.2 & F, nxO \\
$6-5 \ldots \ldots$. & 25 & 23.0 & 7.0 & 18.1 & F, nxO \\
$6-6 \ldots \ldots$. & 50 & 26.5 & 8.1 & 19.2 & F, nxO \\
$6-7 \ldots \ldots$. & 50 & 46.5 & 14.2 & 25.3 & F, BO \\
$6-8 \ldots \ldots$. & 100 & 56.5 & 17.2 & 28.3 & B \\
$6-9 . \ldots .$. & 100 & 57.5 & 17.5 & 28.6 & F, O \\
\hline
\end{tabular}

\begin{tabular}{|c|c|c|c|c|}
\hline Sample & Weight & Field No. & Depth (meters) & Comments \\
\hline No. & (grams) & $\begin{array}{l}\text { (=depth } \\
\text { in feet) }\end{array}$ & $\begin{array}{c}\text { Below } \\
\text { mudline } \\
\text { Below sea level } \\
\text { (at base) }\end{array}$ & \\
\hline
\end{tabular}

Borehole HLA 7 (Mf5724)

Latitude $70^{\circ} 27^{\prime} 12.14^{\prime \prime} \mathrm{N}$. Longitude $148^{\circ} 05^{\prime} 16.51^{\prime \prime} \mathrm{W}$. Sea ice $1.3 \mathrm{~m}$ thick Mudline $7.7 \mathrm{~m}$ below sea level Total depth $38.2 \mathrm{mbelow}$ sea level

\begin{tabular}{lrcccc}
\hline $7-1 \ldots \ldots$. & 50 & $0.0-0.2$ & $0.0-0.1$ & 7.8 & F, O \\
$7-2 \ldots \ldots$. & 50 & $1.0-1.3$ & $0.3-0.4$ & 8.1 & F, O \\
$7-3 \ldots \ldots$. & 100 & $3.7-6.0$ & $1.1-1.8$ & 9.5 & F, O \\
$7-4 \ldots \ldots$. & 100 & 6.8 & 2.1 & 9.8 & F, O \\
$7-5 \ldots \ldots$. & 50 & $8.3-8.4$ & $2.5-2.6$ & 10.3 & F, O \\
$7-6 \ldots \ldots$. & 100 & $14.2-14.8$ & $4.3-4.5$ & 12.2 & F, O \\
$7-7 \ldots \ldots$. & 50 & $21.0-23.5$ & $6.4-7.2$ & 14.9 & F, O \\
$7-8 \ldots \ldots$. & 100 & 24.1 & 7.4 & 15.1 & F, O \\
$7-9 \ldots \ldots$. & 100 & $25.1-25.3$ & 7.7 & 15.4 & F, nxO \\
$7-10 \ldots$. & 50 & $26.7-26.8$ & $8.1-8.2$ & 15.9 & F, O \\
$7-11 \ldots$. & 100 & $33.8-34.3$ & $10.3-10.5$ & 18.2 & F, nxO \\
$7-12 \ldots$. & 50 & $40.8-40.9$ & $12.4-12.5$ & 20.2 & F, O \\
$7-13 \ldots$. & 100 & $47.6-47.7$ & 14.5 & 22.2 & F, O \\
$7-14 \ldots$. & 100 & 58.3 & 17.8 & 25.5 & B
\end{tabular}

Borehole HLA 8 (Mf5725)

Latitude $147^{\circ} 53^{\prime} 21.44^{\prime \prime} \mathrm{N}$. Longitude $70^{\circ} 30^{\circ} 01.82^{\prime \prime} \mathrm{W}$. Sea ice $1.6 \mathrm{~m}$ thick Mudline $14.0 \mathrm{~m}$ below sea level Total depth $44.6 \mathrm{mbelow}$ sea level

\begin{tabular}{rrcccc}
\hline $8-1 \ldots \ldots$. & 50 & 5.5 & 1.7 & 15.6 & F, O \\
$8-2 \ldots \ldots$. & 25 & $14.5-16.0 \mathrm{~A}$ & 4.4 & 18.4 & F, O \\
$8-3 \ldots \ldots$. & 100 & $14.5-16.0 \mathrm{~B}$ & 4.9 & 18.9 & F, nxO \\
$8-4 \ldots \ldots$. & 50 & $20.0-23.0$ & $6.1-7.0$ & 21.0 & F, O \\
$8-5 \ldots \ldots$. & 50 & $37.0-38.0$ & $11.3-11.6$ & 25.6 & F, O \\
$8-6 \ldots \ldots$. & 100 & $38.0-40.0$ & $11.6-12.2$ & 26.2 & F, O \\
$8-7 \ldots \ldots$. & 100 & $47.4-47.5$ & $14.4-14.5$ & 28.5 & F, O \\
$8-8 \ldots \ldots$. & 100 & $67.0-68.5$ & $20.4-20.9$ & 34.9 & F, O \\
$8-9 \ldots \ldots$. & 100 & 95.5 & 29.1 & 43.1 & O, BF
\end{tabular}

\begin{tabular}{lll}
$8-9 \ldots \ldots . . .100$ & 29.1 & 43.1 \\
\hline
\end{tabular}

Latitude $70^{\circ} 22^{\prime} 48.26^{\prime \prime} \mathrm{N}$. Longitude $147^{\circ} 52^{\prime} 42.32^{\prime \prime} \mathrm{W}$. Sea ice $1.3 \mathrm{~m}$ thick Mudline $5.3 \mathrm{~m}$ below sea level Total depth $44.9 \mathrm{~m}$ below sea level

\begin{tabular}{cccccc}
\hline $9-1 \ldots .$. & 100 & 2.5 & 0.8 & 6.1 & BF, O \\
$9-2 \ldots \ldots$. & 100 & $5.7-5.8$ & $1.7-1.8$ & 7.1 & BF, O \\
$9-3 \ldots \ldots$. & 100 & $13.0-13.5$ & $4.0-4.1$ & 9.4 & B \\
$9-4 \ldots \ldots$. & 100 & $13.5-14.0$ & $4.1-4.3$ & 9.6 & B \\
$9-5 \ldots \ldots$. & 100 & $29.5-30.0$ & $9.0-9.2$ & 14.4 & F, O \\
$9-6 \ldots \ldots$. & 100 & 36.5 & 11.1 & 16.4 & O, BF \\
$9-7 \ldots \ldots$. & 100 & $40.5-42.0$ & $12.3-12.8$ & 18.1 & O, BF \\
\hline
\end{tabular}

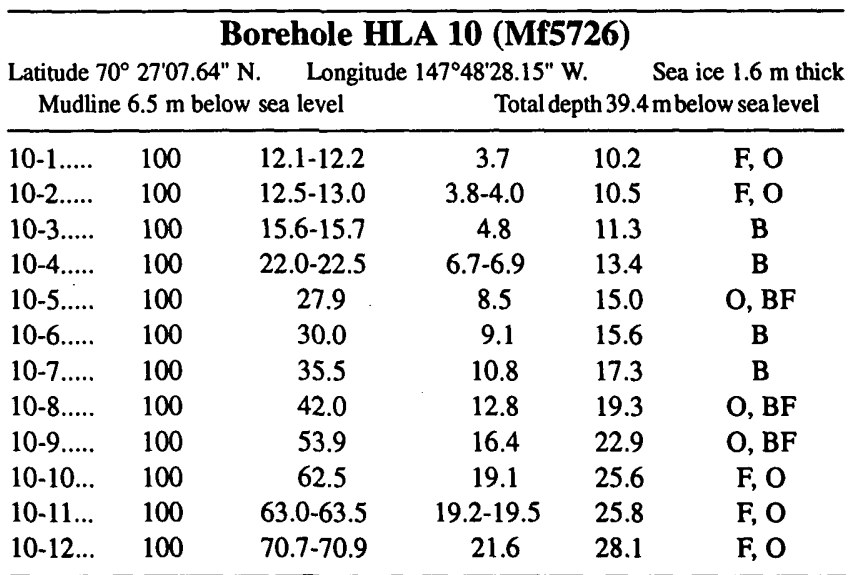




\section{APPENDIX 1. REGISTER OF MICROFOSSIL LOCALITIES, BEAUFORT SEA SHELF, ALASKA-CONTINUED}

\begin{tabular}{|c|c|c|c|c|c|}
\hline \multirow{2}{*}{$\begin{array}{l}\text { Sample } \\
\text { No. }\end{array}$} & \multirow{2}{*}{$\begin{array}{l}\text { Weight } \\
\text { (grams) }\end{array}$} & \multirow{2}{*}{$\begin{array}{c}\text { Field No. } \\
\text { (=depth } \\
\text { in feet) }\end{array}$} & \multicolumn{2}{|c|}{ Depth (meters) } & \multirow[t]{2}{*}{ Comments } \\
\hline & & & $\begin{array}{l}\text { Below } \\
\text { mudline }\end{array}$ & $\begin{array}{l}\text { Below sea level } \\
\text { (at base) }\end{array}$ & \\
\hline \multicolumn{6}{|c|}{ Borehole HLA 11 (Mf6108) } \\
\hline \multicolumn{3}{|c|}{$\begin{array}{l}\text { Latitude } 70^{\circ} 23^{\prime} 00.43 " \mathrm{~N} . \quad \text { Long } \\
\text { Mudline } 7.5 \mathrm{~m} \text { below sea level }\end{array}$} & \multicolumn{3}{|c|}{ Total depth $36.5 \mathrm{~m}$ below sea level } \\
\hline $11-1 \ldots .$. & 100 & $12.3-12.5$ & 3.8 & 11.3 & $\mathrm{~F}, \mathrm{O}$ \\
\hline $11-2 \ldots \ldots$ & 50 & 13.6-13.7 & $4.2-4.9$ & 12.4 & B \\
\hline $11-3 \ldots .$. & 100 & $23.6-23.7$ & 7.2 & 14.7 & F, O \\
\hline $11-4 \ldots .$. & 100 & $40.0-40.7$ & $12.2-12.4$ & 19.8 & $\mathrm{~F}, \mathrm{O}$ \\
\hline $11-5 \ldots .$. & 50 & 56.0 & 17.1 & 24.6 & F, O \\
\hline $11-6 \ldots .$. & 50 & 60.5 & 18.4 & 25.9 & $\mathrm{~F}, \mathrm{O}$ \\
\hline $11-7 \ldots \ldots$ & 100 & 64.0 & 19.5 & 27.0 & $\mathrm{nxF}, \mathrm{O}$ \\
\hline
\end{tabular}

\section{Borehole HLA 12 (Mf5727)}

Latitude $70^{\circ} 26^{\prime} 39.66^{\prime \prime} \mathrm{N}$. Longitude $147^{\circ} 30^{\prime} 26.03^{\prime \prime} \mathrm{W}$. Sea ice $1.4 \mathrm{~m}$ thick Mudline $15.2 \mathrm{~m}$ below sea level Total depth $106.9 \mathrm{~m}$ below sea level

\begin{tabular}{lrcccc}
\hline $12-1 \ldots .$. & 100 & 4.5 & 1.4 & $16.6 \mathrm{~m}$ & F, O \\
$12-2 \ldots .$. & 100 & 5.6 & 1.7 & $16.9 \mathrm{~m}$ & F, O \\
$12-3 \ldots \ldots$ & 100 & $12.0-12.5$ & $3.7-3.8$ & $18.9 \mathrm{~m}$ & F, O \\
$12-4 \ldots \ldots$ & 100 & $19.5-20.0$ & $5.9-6.1$ & $21.3 \mathrm{~m}$ & F, O \\
$12-5 \ldots .$. & 100 & $21.0-21.5$ & $6.4-6.6$ & $21.8 \mathrm{~m}$ & F, O \\
$12-6 \ldots .$. & 100 & $27.5-28.0$ & $8.4-8.5$ & $23.7 \mathrm{~m}$ & F, O \\
$12-7 \ldots .$. & 50 & 34.0 & 10.4 & $25.6 \mathrm{~m}$ & F, O \\
$12-8 \ldots .$. & 100 & 54.5 & 16.6 & $31.8 \mathrm{~m}$ & F, O \\
$12-9 \ldots .$. & 100 & 55.0 & 16.8 & $32.0 \mathrm{~m}$ & F, O \\
$12-10 \ldots$ & 100 & 60.5 & 18.4 & $33.6 \mathrm{~m}$ & F, O \\
$12-11 \ldots$ & 100 & 65.5 & 20.0 & $35.2 \mathrm{~m}$ & F, O \\
$12-12 \ldots$ & 50 & 70.5 & 21.5 & $36.7 \mathrm{~m}$ & F, O \\
$12-13 \ldots$ & 100 & 80.5 & 24.5 & $39.7 \mathrm{~m}$ & F, O \\
$12-14 \ldots$ & 100 & 85.5 & 26.1 & $41.3 \mathrm{~m}$ & F, nxO \\
$12-15 \ldots$ & 100 & 90.5 & 27.6 & $42.8 \mathrm{~m}$ & F, nxO \\
$12-16 \ldots$. & 100 & 95.5 & 29.1 & $44.3 \mathrm{~m}$ & F, nxO
\end{tabular}

\section{Borehole HLA 13 (Mf6109)}

Latitude $70^{\circ} 18^{\prime} 57.67^{\prime \prime} \mathrm{N}$. Longitude $147^{\circ} 38^{\prime} 48.46^{\prime \prime} \mathrm{W}$. Sea ice $1.7 \mathrm{~m}$ thick Mudline $5.6 \mathrm{~m}$ below sea level Total depth: $36.7 \mathrm{~m}$ below sea level

\begin{tabular}{cccccc}
\hline $13-1 . \ldots$. & 100 & $2.8-3.0$ & 0.9 & 6.5 & F, O \\
$13-2 \ldots .$. & 100 & $8.0-8.2$ & $2.4-2.5$ & 8.1 & B \\
$13-3 \ldots .$. & 100 & $18.7-19.2$ & $5.7-5.9$ & 11.5 & F, O \\
$13-4 \ldots .$. & 100 & 34.0 & 10.4 & 16.0 & F, O \\
$13-5 \ldots .$. & 100 & 44.5 & 13.6 & 19.2 & F, O
\end{tabular}

\section{Borehole HLA 14 (Mf5728)}

\begin{tabular}{|c|c|c|c|c|c|}
\hline \multirow{2}{*}{\multicolumn{3}{|c|}{$\begin{array}{l}\text { Latitude } 70^{\circ} 16^{\prime} 35.96^{\prime \prime} \mathrm{N} \text {. } \\
\text { Mudline } 6.5 \mathrm{~m} \text { below sea level }\end{array}$}} & \multicolumn{2}{|c|}{ congitude $147^{\circ} 23^{\circ} 42.38^{\prime \prime} \mathrm{W}$. } & \multirow{2}{*}{$\begin{array}{l}\text { Sea ice } 1.5 \mathrm{~m} \\
\text { low sea level }\end{array}$} \\
\hline & & & \multicolumn{2}{|c|}{ Total depth $37.2 \mathrm{~m}$ below sea level } & \\
\hline $14-1 \ldots .$. & 100 & $6.0-6.5$ & $1.8-2.0$ & 8.5 & $\mathrm{~F}, \mathrm{O}$ \\
\hline $14-2 \ldots .$. & 100 & $7.5-7.8$ & 2.3-2.4 & 8.9 & $\mathrm{~F}, \mathrm{O}$ \\
\hline $14-3 \ldots .$. & 50 & 18.0 & 5.5 & 12.9 & $\mathrm{~F}, \mathrm{O}$ \\
\hline $14-4 \ldots .$. & 50 & $28.0-28.5$ & $8.5-8.7$ & 15.2 & F, O \\
\hline $14-5 \ldots .$. & 50 & 31.0 & 9.5 & 16.0 & $\mathrm{BF}, \mathrm{O}$ \\
\hline $14-6 \ldots .$. & 100 & $33.0-33.5$ & $10.1-10.2$ & 16.7 & $\mathrm{BF}, \mathrm{O}$ \\
\hline 14-6A... & 100 & 44.5 & 13.6 & 20.1 & B \\
\hline $14-7 \ldots \ldots$ & 100 & 54.5 & 16.5 & 23.0 & $\mathrm{~F}, \mathrm{O}$ \\
\hline
\end{tabular}

\begin{tabular}{lcccc}
\hline Sample & Weight & Field No. & Depth (meters) & Comments \\
No. & (grams) & $\begin{array}{c}\text { (=depth } \\
\text { in feet) }\end{array}$ & $\begin{array}{c}\text { Below } \\
\text { mudline }\end{array}$ & $\begin{array}{c}\text { Below sea level } \\
\text { (at base) }\end{array}$
\end{tabular}

\begin{tabular}{|c|c|c|c|c|c|}
\hline \multicolumn{6}{|c|}{ Borehole HLA 15 (Mf5731) } \\
\hline \multirow{2}{*}{\multicolumn{3}{|c|}{$\begin{array}{l}\text { Latitude } 70^{\circ} 13^{\prime} 18.37^{\prime \prime} \mathrm{N} . \\
\text { Mudline } 5.5 \mathrm{~m} \text { below sea level }\end{array}$}} & \multirow{2}{*}{\multicolumn{3}{|c|}{$\begin{array}{l}{ }^{\circ} 00^{\prime} 20.90^{\prime \prime} \mathrm{W} . \quad \text { Sea-ice } 1.5 \mathrm{~m} \\
\text { Total depth: } 96.9 \mathrm{~m} \text { below sea level }\end{array}$}} \\
\hline & & & & & \\
\hline $15-1 \ldots \ldots$ & 100 & 5.2 & 1.6 & 7.1 & F, O \\
\hline $15-2 \ldots \ldots$ & 100 & $6.0-6.6$ & $1.8-2.0$ & 7.5 & F, O \\
\hline $15-3 \ldots \ldots$ & 100 & $16.5-16.7$ & $5.0-5.1$ & 10.5 & $\mathrm{~F}, \mathrm{O}$ \\
\hline $15-4 \ldots \ldots$ & 100 & 19.0 & 5.8 & 11.3 & $\mathrm{~F}, \mathrm{O}$, slump? \\
\hline $15-5 \ldots$. & 50 & $25.6-25.7$ & 7.8 & 13.3 & B \\
\hline $15-6 \ldots .$. & 100 & 49.5 & 15.1 & 20.6 & $\mathrm{O}, \mathrm{BF}$ \\
\hline $15-7 \ldots \ldots$ & 100 & $227.5-229.0$ & $69.3-69.8$ & 75.3 & B \\
\hline $15-8 \ldots$. & 100 & 237.5 & 72.4 & 77.9 & B \\
\hline $15-9 \ldots$. & 100 & 248.5 & 75.7 & 81.2 & B \\
\hline $15-10 \ldots$ & 100 & 258.0 & 78.7 & 84.1 & B \\
\hline $15-11 \ldots$ & 100 & $267.0-268.5$ & $81.4-81.8$ & 87.3 & B \\
\hline $15-12 \ldots$ & 100 & $277.5-278.0$ & $84.6-84.7$ & 90.2 & B \\
\hline
\end{tabular}

Borehole HLA 16 (Mf5623)

Latitude $70^{\circ} 16^{\prime} 11.75^{\prime \prime} \mathrm{N}$. Longitude $146^{\circ} 42^{\prime} 46.36^{\prime \prime} \mathrm{W}$. Sea ice $1.4 \mathrm{~m}$ thick Mudline $9.2 \mathrm{~m}$ below sea level Total depth $42.7 \mathrm{~m}$ below sea level

\begin{tabular}{cccccc}
\hline $16-1 \ldots .$. & 100 & $2.5-3.0$ & $0.8-0.9$ & 10.0 & F, O \\
$16-2 \ldots .$. & 100 & $3.6-4.0$ & $1.1-1.2$ & 10.4 & F, O \\
$16-3 \ldots .$. & 100 & $5.0-6.5$ & $1.5-2.0$ & 11.2 & F, O \\
$16-4 \ldots .$. & 100 & 7.0 & 2.1 & 11.3 & F, O \\
$16-5 \ldots .$. & 100 & $18.2-18.4$ & $5.5-5.6$ & 14.8 & F, O \\
$16-6 \ldots .$. & 100 & $25.5-26.0$ & $7.8-7.9$ & 17.1 & B \\
$16-7 \ldots .$. & 100 & $26.8-27.0$ & 8.2 & 17.4 & B \\
$16-8 \ldots .$. & 100 & $34.5-37.4$ & $10.5-11.4$ & 20.6 & F, O \\
$16-9 \ldots .$. & 100 & $39.5-41.5$ & $12.1-12.7$ & 21.9 & O, BF \\
$16-10 \ldots$. & 100 & $48.0-48.5$ & $14.6-14.8$ & 24.0 & F, O \\
$16-11 \ldots$. & 100 & 67.5 & 20.6 & 29.8 & F, O \\
$16-12 \ldots$ & 100 & 72.5 & 22.1 & 31.3 & F, O
\end{tabular}

\section{Borehole HLA 17 (Mf5624)}

Latitude $70^{\circ} 16^{\prime} 08.53^{\prime \prime} \mathrm{N}$. Longitude $146^{\circ} 27^{\prime} 31.56^{\prime \prime} \mathrm{W}$. Sea ice $1.6 \mathrm{~m}$ thick Mudline $14.5 \mathrm{~m}$ below sea level Total depth $46.1 \mathrm{~m}$ below sea level

\begin{tabular}{cccccc}
\hline $17-1 \ldots .$. & 50 & 2.0 & 0.6 & 15.1 & F, O \\
$17-2 \ldots .$. & 100 & $2.0-2.7$ & $0.6-0.8$ & 15.2 & F, O \\
$17-3 \ldots .$. & 100 & $3.0-3.1$ & 0.9 & 15.4 & F, O \\
$17-4 \ldots .$. & 100 & 5.5 & 1.7 & 16.2 & F, O \\
$17-5 \ldots .$. & 100 & $7.0-8.3$ & $2.1-2.5$ & 16.8 & F, O \\
$17-6 \ldots .$. & 100 & $8.0-8.2$ & $2.4-2.5$ & 17.0 & F, O \\
$17-7 \ldots .$. & 50 & 9.5 & 2.9 & 17.4 & F, O \\
$17-8 \ldots .$. & 100 & 10.0 & 3.1 & 17.6 & F, O \\
$17-9 \ldots .$. & 100 & 13.5 & 4.1 & 18.6 & F, O \\
$17-10 \ldots$. & 100 & 15.0 & 4.5 & 19.0 & F, O \\
$17-11 \ldots$ & 100 & 17.5 & 5.3 & 19.8 & F, O \\
$17-12 \ldots$ & 100 & 18.5 & 5.6 & 20.1 & F, O \\
$17-13 \ldots$ & 100 & 20.5 & 6.3 & 20.8 & F, O \\
$17-14 \ldots$ & 100 & 27.0 & 8.2 & 22.7 & F, O \\
$17-15 \ldots$ & 100 & 37.0 & 11.3 & 25.8 & F, O \\
$17-16 \ldots$ & 100 & 42.0 & 12.8 & 27.3 & F, O \\
$17-17 \ldots$ & 100 & $51.5-52.0$ & $15.7-15.8$ & 30.3 & F, O \\
$17-18 \ldots$ & 100 & 73.5 & 22.4 & 36.9 & F, O \\
$17-19 \ldots$ & 100 & 82.0 & 25.0 & 39.5 & F, O \\
$17-20 \ldots$ & 100 & 103.0 & 31.4 & 45.9 & F, O \\
\hline. & & & & &
\end{tabular}




\section{APPENDIX 1. REGISTER OF MICROFOSSIL LOCALITIES, BEAUFORT SEA SHELF, ALASKA-CONTINUED}

\begin{tabular}{|c|c|c|c|c|}
\hline Sample & Weight & Field No. & Depth (meters) & Comments \\
\hline No. & (grams & $\begin{array}{l}\text { (=depth } \\
\text { in feet) }\end{array}$ & $\begin{array}{cc}\text { Below } & \text { Below sea level } \\
\text { mudline } & \text { (at base) }\end{array}$ & \\
\hline
\end{tabular}

\begin{tabular}{|c|c|c|c|c|c|}
\hline \multicolumn{6}{|c|}{$\begin{array}{l}\text { Borehole HLA } 18 \text { (Mf5625) } \\
\end{array}$} \\
\hline \multirow{2}{*}{\multicolumn{2}{|c|}{$\begin{array}{l}\text { Latitude } 70^{\circ} 12^{\prime} 37.40^{\prime \prime} \\
\text { Mudline } 11.3 \mathrm{~m} \text { be }\end{array}$}} & \multicolumn{2}{|c|}{ Longitude $146^{\circ} 02^{\prime} 35.85^{\prime \prime}$} & \multicolumn{2}{|c|}{ Sea ice $2.0 \mathrm{~m}$ thick } \\
\hline & & low sea level & Total de & th 103.7 & elow sea level \\
\hline $18-1 \ldots .$. & 100 & 0.0 & 0.0 & 11.3 & F, O \\
\hline $18-2 \ldots \ldots$ & 100 & 2.5 & 0.8 & 12.1 & $\mathrm{~F}, \mathrm{O}$ \\
\hline $18-3 \ldots .$. & 100 & 4.0 & 1.2 & 12.5 & F, O \\
\hline $18-4 \ldots .$. & 100 & 5.5 & 1.7 & 13.0 & F, O \\
\hline $18-5 \ldots .$. & 100 & 6.0 & 1.8 & 13.1 & F, O \\
\hline $18-6 \ldots .$. & 100 & 7.5 & 2.3 & 13.6 & B \\
\hline $18-7 \ldots .$. & 50 & 11.0 & 3.4 & 14.7 & BF, $\mathrm{O}$ \\
\hline $18-8 \ldots .$. & 100 & 13.0 & 4.0 & 15.3 & $\mathbf{F}, \mathbf{O}$ \\
\hline $18-9 \ldots .$. & 100 & $14.3-14.8$ & 4.4-4.5 & 15.8 & $\mathrm{~F}, \mathrm{O}$ \\
\hline $18-10 \ldots$ & 100 & $21.6-22.0$ & $6.6-6.7$ & 18.0 & $\mathrm{~F}, \mathrm{O}$ \\
\hline $18-11 \ldots$ & 100 & 23.0 & 7.0 & 18.3 & B \\
\hline $18-12 \ldots$ & 100 & 26.5 & 8.1 & 19.4 & B \\
\hline $18-13 \ldots$ & 100 & 27.5 & 8.4 & 19.7 & $\mathrm{~F}, \mathrm{O}$ \\
\hline $18-14 \ldots$ & 100 & $30.0-30.5$ & $9.1-9.3$ & 20.6 & $\mathrm{~F}, \mathrm{O}$ \\
\hline $18-15 \ldots$ & 100 & $30.5-32.0$ & $9.3-9.8$ & 21.1 & $\mathrm{~F}, \mathrm{nxO}$ \\
\hline $18-16 \ldots$ & 100 & 36.5 & 11.1 & 22.4 & $\mathrm{~F}, \mathrm{nxO}$ \\
\hline $18-17 \ldots$ & 100 & $40.5-42.0$ & $12.3-12.8$ & 24.1 & $\mathrm{BF}, \mathrm{nxO}$ \\
\hline $18-18 \ldots$ & 100 & $45.5-47.0$ & $13.9-14.3$ & 25.6 & $\mathrm{~F}, \mathrm{nxO}$ \\
\hline $18-19 \ldots$ & 100 & $50.5-52.0$ & $15.4-15.8$ & 27.1 & $\mathrm{~F}, \mathrm{nxO}$ \\
\hline $18-20 \ldots$ & 25 & $55.5-57.0$ & $16.9-17.4$ & 28.7 & $\mathrm{~F}, \mathrm{O}$ \\
\hline $18-21 \ldots$ & 100 & $65.5-67.0$ & 20.0 & 31.3 & F, O \\
\hline $18-22 \ldots$ & 100 & $70.5-72.0$ & $21.5-22.0$ & 33.3 & $\mathrm{~F}, \mathrm{O}$ \\
\hline $18-23 \ldots$ & 100 & $75.5-77.0$ & $23.0-23.5$ & 34.8 & F, O \\
\hline $18-24 \ldots$ & 100 & $80.5-82.0$ & $24.5-25.0$ & 36.3 & $\mathrm{~F}, \mathrm{O}$ \\
\hline $18-25 \ldots$ & 100 & $85.5-87.0$ & $26.1-26.5$ & 37.8 & $\mathrm{~F}, \mathrm{O}$ \\
\hline $18-26 \ldots$ & 100 & 92.0 & 28.0 & 39.3 & $\mathrm{~F}, \mathrm{O}$ \\
\hline $18-27 \ldots$ & 100 & 111.5 & 34.0 & 45.3 & $\mathrm{~F} ; \mathrm{O}$ \\
\hline $18-28 \ldots$ & 100 & 122.0 & 37.2 & 48.5 & F, O \\
\hline $18-29 \ldots$ & 100 & $132.0-132.5$ & $40.2-40.4$ & 51.7 & $\mathrm{~F}, \mathrm{O}$ \\
\hline $18-30 \ldots$ & 100 & 142.5 & 43.4 & 54.7 & $\mathrm{~F}, \mathrm{O}$ \\
\hline $18-31 \ldots$ & 100 & $182.0-183.0$ & $55.5-55.8$ & 67.1 & $\mathrm{~F}, \mathrm{O}$ \\
\hline $18-32 \ldots$ & 100 & 212.5 & 64.8 & 76.1 & B \\
\hline $18-33 \ldots$ & 100 & 251.5 & 76.7 & 88.0 & B \\
\hline $18-34 \ldots$ & 100 & $261.5-263.0$ & $79.1-80.2$ & 91.5 & $\mathrm{~F}, \mathrm{O}$ \\
\hline $18-35 \ldots$ & 100 & 273.0 & 83.2 & 94.5 & $\mathrm{~F}, \mathrm{O}$ \\
\hline $18-36 \ldots$ & 100 & $291.5-293.0$ & $88.9-89.3$ & 100.6 & B \\
\hline $18-37 \ldots$ & 100 & $301.5-303.0$ & $91.9-92.4$ & 103.7 & $\mathrm{~F}, \mathrm{O}$ \\
\hline
\end{tabular}

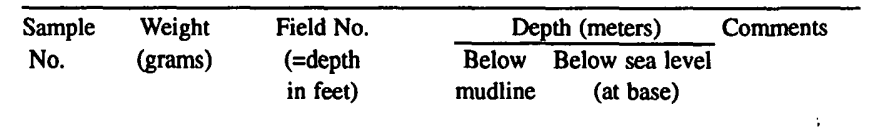

\begin{tabular}{|c|c|c|c|c|c|}
\hline \multicolumn{6}{|c|}{ Borehole HLA 19 (Mf5729) } \\
\hline \multicolumn{3}{|c|}{$\begin{array}{l}\text { Latitude } 70^{\circ} 18^{\prime} 48.96^{\prime \prime} \mathrm{N} \text {. Lon } \\
\text { Mudline } 10.5 \mathrm{~m} \text { below sea level }\end{array}$} & \multicolumn{2}{|c|}{ ongitude $146^{\circ} 58^{\prime} 03.03^{\prime \prime} \mathrm{W}$. } & $\begin{array}{l}\text { Sea ice } 1.7 \mathrm{~m} \\
\text { low sea level }\end{array}$ \\
\hline $19-1 \ldots .$. & 100 & $0.7-1.0$ & $0.2-0.3$ & 10.8 & F, $O$ \\
\hline $19-2 \ldots .$. & 100 & 1.5 & 0.5 & 11.0 & $\mathrm{~F}, \mathrm{nxO}$ \\
\hline $19-3 \ldots . .$. & 100 & 4.4 & 1.3 & 11.8 & $\mathrm{~F}, \mathrm{O}$ \\
\hline $19-4 \ldots . .$. & 100 & 21.2 & 6.5 & 17.0 & $\mathrm{~F}, \mathrm{O}$ \\
\hline $19-5 \ldots . .$. & 100 & 26.3-26.5 & $8.0-8.1$ & 18.6 & F, O \\
\hline $19-6 \ldots . .$. & 50 & 32.3-32.4 & $9.8-9.9$ & 20.4 & F, O \\
\hline $19-7 \ldots .$. & 100 & 35.5 & 10.8 & 21.3 & $\mathrm{~F}, \mathrm{O}$ \\
\hline $19-8 \ldots . .$. & 100 & 39.0 & 11.9 & 22.4 & $\mathrm{~F}, \mathrm{O}$ \\
\hline $19-9 \ldots . .$. & 100 & 46.5 & 14.2 & 24.7 & F, $\mathrm{O}$ \\
\hline $19-10 \ldots$ & 100 & $51.1-51.3$ & 15.6 & 26.1 & $\mathrm{~F}, \mathrm{nxO}$ \\
\hline $19-11 \ldots$ & 100 & 57.6 & 17.6 & 28.1 & $\mathrm{~F}, \mathrm{O}$ \\
\hline $19-12 \ldots$ & 100 & 62.3 & 19.0 & 29.5 & F, O \\
\hline $19-13 \ldots$ & 100 & 67.0 & 20.4 & 30.9 & F, O \\
\hline $19-14 \ldots$ & 100 & 71.5 & 21.8 & 32.4 & F, O \\
\hline $19-15 \ldots$ & 100 & $76.2-76.4$ & $23.2-23.3$ & 33.8 & $\mathrm{~F}, \mathrm{O}$ \\
\hline $19-16 \ldots$ & 100 & $77.0-77.3$ & $23.5-23.6$ & 34.0 & $\mathrm{~F}, \mathrm{O}$ \\
\hline $19-17 \ldots$ & 100 & 92.0 & 28.0 & 38.5 & F, $O$ \\
\hline $19-18 \ldots$ & 100 & 96.5 & 29.4 & 39.9 & $\mathrm{~F}, \mathrm{O}$ \\
\hline $19-19 \ldots$ & 100 & 115.4 & 35.2 & 45.7 & B \\
\hline
\end{tabular}

\begin{tabular}{|c|c|c|c|c|c|}
\hline & Bor & rehole HI & $20(\mathrm{M}$ & 30) & \\
\hline $\begin{array}{r}\text { Latitude } 7 \\
\text { Mudlin }\end{array}$ & 21 '59.76" N. & Longitu & $47^{\circ} 14^{\prime} 38.9$ & th. 450 & $1.5 \mathrm{~m}$ thick \\
\hline $20-1 \ldots .$. & 100 & 4.0 & 1.2 & 12.5 & $\mathrm{~F}, \mathrm{O}$ \\
\hline $20-2 \ldots \ldots$ & 100 & $14.6-15.0$ & $4.5-4.6$ & 15.9 & $\mathrm{~F}, \mathrm{O}$ \\
\hline $20-3 \ldots .$. & 100 & $20.5-21.0$ & 6.3-6.4 & 17.7 & $\mathrm{~F}, \mathrm{O}$ \\
\hline $20-4 \ldots$ & 100 & 27.5 & 8.4 & 19.7 & $\mathrm{~F}, \mathrm{O}$ \\
\hline $20-5 \ldots .$. & 100 & 40.0 & 12.2 & 23.5 & $\mathrm{~F}, \mathrm{O}$ \\
\hline $20-6 \ldots .$. & 100 & 41.5 & 12.7 & 24.0 & F, O \\
\hline $20-7 \ldots .$. & 50 & 42.5 & 13.0 & 24.3 & $\mathrm{~F}, \mathrm{O}$ \\
\hline $20-8 \ldots .$. & 100 & 49.0 & 14.9 & 26.2 & $\mathrm{~F}, \mathrm{O}$ \\
\hline $20-9 \ldots .$. & 100 & 54.0 & 16.5 & 27.8 & F, O \\
\hline $20-10 \ldots$ & 100 & 57.5 & 17.5 & 28.8 & $\mathrm{~F}, \mathrm{O}$ \\
\hline $20-11 \ldots$ & 100 & 64.0 & 19.5 & 30.8 & F, $O$ \\
\hline $20-12 \ldots$ & 100 & 69.0 & 21.0 & 32.3 & F, BO \\
\hline $20-13 \ldots$ & 100 & 73.5 & 22.4 & 33.7 & $\mathrm{~F}, \mathrm{O}$ \\
\hline $20-14 \ldots$ & 100 & 79.0 & 24.1 & 35.4 & F, O \\
\hline $20-15 \ldots$ & 100 & 84.0 & 25.6 & 36.9 & $\mathrm{~F}, \mathrm{O}$ \\
\hline $20-16 \ldots$ & 100 & 89.0 & 27.1 & 38.4 & $\mathrm{~F}, \mathrm{O}$ \\
\hline $20-17 \ldots$ & 100 & 97.5 & 29.7 & 41.0 & F, O \\
\hline $20-18 \ldots$ & 100 & 99.0 & 30.2 & 41.5 & $\mathrm{BF}, \mathrm{O}$ \\
\hline
\end{tabular}




\section{APPENDIX 2. TAXONOMIC NOTES, BENTHIC FORAMINIFERS}

Ammotium cassis (Parker) - Loeblich and Tappan, 1953, Smithsonian Misc. Coll., v. 121, no. 7, p. 33-34, pl. 2, figs. 12-18. - McDougall and others, 1986, U.S. Geological Survey Bull. 1598, p. 52.

Astacolus hyalacrulus Loeblich and Tappan, 1953, Smithsonian Misc. Coll., v. 121, no. 7, p. 52-53, pl. 9, figs. 1-4.

Astrononion gallowayi Loeblich and Tappan, 1953, Smithsonian Misc. Coll., v. 121, no. 7, p. 90-92, pl. 17, figs. 4-7.

Bolivina pseudopunctata Hoeglund - Loeblich and Tappan, 1953, Smithsonian Misc. Coll., v. 121, no. 7, p. 111, pl. 20, figs. 13-14.

Bolivina sp. - These specimens are juveniles that cannot be identified to species.

Buccella frigida (Cushman) = Pulvinulina frigida Cushman, 1922, Contr. Canadian Biol. (1921), No. 9, p. 12. = Buccella frigida (Cushman) - Loeblich and Tappan, 1953, Smithsonian Misc. Coll., v. 121 , no. 7 , p. 115 , pl. 22, figs. 2, 3. McDougall and others, 1986, U.S. Geological Survey Bull. 1598, p. 52, pl. 1, fig. 2. - This paper, pl. 1, fig. 1.

Buccella inusitata Andersen, 1952, Washington Acad. Sci. Jour., v. 42 , p. 148 , tfs. 10, 11. - Loeblich and Tappan, 1953, Smithsonian Misc. Coll., v. 121 , no. 7 , p. 116 , pl. 22 , fig. 1 . - McDougall and others, 1986, U.S. Geological Survey Bull. 1598 , p. 52.

Buccella sp. - McDougall and others, 1986, U.S. Geological Survey Bull. 1598, p. 52. - These specimens are probably juveniles of Buccella frigida.

Cassidulina crassa d'Orbigny - Cushman, 1936, Geological Society of America Bull., v. 47, p. 434, pl. 5, fig. 12.

Cassidulina islandica Norvang, 1945, Zoology of Iceland, v. 2, pt. 2, p. 41, tfs. 7, 8d-f. - Loeblich and Tappan, 1953, Smithsonian Misc. Coll., v. 121, no. 7, p. 118-120, pl. 24, fig. 1. McDougall and others, 1986, U.S. Geological Survey Bull. 1598, p. 52, pl. 1, fig. 3. - This paper, pl. 1, fig. 2.

Cassidulina norcrossi Cushman, 1933, Smithsonian Misc. Coll., v. 89, no. 9, p. 7, pl. 2, fig. 7. - Loeblich and Tappan, 1953, Smithsonian Misc. Coll., v. 121, no. 7, p. 120, pl. 24, fig. 2. - McDougall and others, 1986, U.S. Geological Survey Bull. 1598, p. 52, pl. 1, fig. 4. - This paper, pl. 1, fig. 3.

Cibicides lobatulus (Walker and Jacob) - Feyling-Hanssen, 1971, Geological Society of Denmark Bull., v. 21, p. 260, pl. 9, figs. 9-14. - This paper, pl. 1, fig. 4.

Cibicides mckannai Galloway and Wissler, 1927, Jour. of Paleontology, v. 1, p. 65 , pl. 10 , figs. 5,6 .

Cibicides sp. - Specimen that cannot be identified to species.

Cyclogyra involvens (Reuss) = Cornuspira involvens (Reuss) Loeblich and Tappan, 1953, Smithsonian Misc. Coll., v. 121, no. 7 , p. 49 , pl. 7 figs. $4,5 .=$ Cyclogyra involvens (Reuss) McDougall and others, 1986, U.S. Geological Survey Bull. 1598, p. 52, pl. 1, fig. 6. - This paper, pl. 1, fig. 5.

Cyclammina spp. - Specimens are broken or poorly preserved individuals of Cyclammina.

Dentalina baggi Galloway and Wissler - Feyling-Hanssen, 1971, Geological Society of Denmark Bull., v. 21, p. 199, pl. 3, fig. 1. - Loeblich and Tappan, 1953, Smithsonian Misc. Coll., v. 121 , no. 7 , p. 54-55, pl. 9, figs. 10-15.
Dentalina frobisherensis Loeblich and Tappan, 1953, Smithsonian Misc. Coll., v. 121 , no. 7, p. 55-56, pl. 10, figs. 1-9. McDougall and others, 1986, U.S. Geological Survey Bull. 1598, p. 52, pl. 1, fig. 7. - This paper, pl. 1, fig. 6.

Dentalina ittai Loeblich and Tappan, 1953, Smithsonian Misc. Coll., v. 121 , no. 7 , p. 56-57, pl. 10, figs. 10-12. - McDougall and others, 1986, U.S. Geological Survey Bull. 1598, p. 52, pl. 1, fig. 9. - This paper, pl. 1, fig. 7.

Dentalina pauperata d'Orbigny - Loeblich and Tappan, 1953, Smithsonian Misc. Coll., v. 121, no. 7, p. 57-58, pl. 9, figs. 79. - McDougall and others, 1986, U.S. Geological Survey Bull. 1598, p. 52. - This paper, pl. 1, fig. 8.

Dentalina spp. - These specimens are broken or poorly preserved individuals of Dentalina.

Discorbis baccata (Heron-Allen and Earland) = Discorbina baccata Heron-Allen and Earland, 1913, Royal Acad. Proceedings, v. 31, sec. 3, p. 124. - This paper, pl. 1, fig. 9.

Eggerella advena (Cushman) - Loeblich and Tappan, 1953, Smithsonian Misc. Coll., v. 121 , no. 7, p. 36-37, pl. 3, figs. 810. - This paper, pl. 1, fig. 10.

Elphidiella? brunnescens Todd, 1957, U.S. Geological Survey Prof. Paper 294-F, p. 230, pl. 28, fig. 18. - This paper, pl. 1, figs. 11, 12.

Elphidiella groenlandica $($ Cushman $)=$ Elphidium groenlandicum Cushman, 1933, Smithsonian Misc. Coll., v. 89, no. 9, p. 4, pl. 1, fig. 10. = Elphidiella groenlandica (Cushman) - Loeblich and Tappan, 1953, Smithsonian Misc. Coll., v. 121, no. 7, p. 106107, pl. 19, figs. 13, 14. - McDougall and others, 1986, U.S. Geological Survey Bull. 1598, p. 52, pl. 1, fig. 10. - This paper, pl. 1, fig. 13.

Elphidium albiumbilicatum (Weiss) = Nonion pauciloculum albiumbilicatum Weiss, 1954, U.S. Geological Survey Prof. Paper 254-G, p. 157, pl. 32, figs. 1, 2. = Elphidium albiumbilicatum (Weiss) - McDougall and others, 1986, U.S. Geological Survey Bull. 1598, p. 52, pl. 1, fig. 11. - This paper, pl. 2 , fig. 1.

Elphidium cf. E. albiumbilicatum (Weiss) - These specimens exhibit some but not all of the distinguishing characteristics of Elphidium albiumbilicatum.

Elphidium asklundi Brotzen - Feyling-Hanssen, 1971, Geological Society of Denmark Bull., v. 21, p. 270, pl. 10, figs. 20 21; pl. 11, figs. 1-5. - McDougall and others, 1986, U.S. Geological Survey Bull. 1598, p. 52, pl. 1, fig. 12. - This paper, pl. 2, fig. 2.

Elphidium cf. E. asklundi Brotzen - McDougall and others, 1986, U.S. Geological Survey Bull. 1598, p. 52, pl. 1, fig. 13. - These specimens are worn and poorly preserved. Their presence in Holocene assemblages is assumed to result from reworking of older material.

Elphidium bartletti Cushman, 1933, Smithsonian Misc. Coll., v. 89, no. 9, p. 4, pl. 1, fig. 9. - Loeblich and Tappan, 1953, Smithsonian Misc. Coll., v. 121, no. 7, p. 96-98, pl. 18, figs. 1014. - McDougall and others, 1986, U.S. Geological Survey Bull. 1598, p. 52, pl. 2, figs. 1-3. - This paper, pl. 2, fig. 3.

Elphidium cf. E. bartletti Cushman - These specimens exhibit some but not all of the distinguishing characteristics of $E l$ phidium bartletti.

Elphidium clavatum Cushman, 1930, U.S. National History Museum Bull., no. 104, pt. 7, p. 20, pl. 7, fig. 10. - Loeblich and Tappan, 1953, Smithsonian Misc. Coll., v. 121, no. 7, p. 98-99, pl. 19, figs. 8-10. - McDougall and others, 1986, 


\section{LATE CENOZOIC BENTHIC FORAMINIFERS OF THE HLA BOREHOLE SERIES, BEAUFORT SEA SHELF, ALASKA}

U.S. Geological Survey Bull. 1598, p. 53, pl. 2, figs. 4, 8. This paper, pl. 2, figs. 4, 5 .

Elphidium excavatum alba Feyling-Hanssen, 1972, Micropaleontology, v. 18, p. 340-341, pl. 3, figs. 1-9. - McDougall and others, 1986, U.S. Geological Survey Bull. 1598, p. 53, pl. 2, fig. 6. - This paper, pl. 2, fig. 6.

Elphidium frigidum Cushman, 1933, Smithsonian Misc. Coll., v. 89, no. 9, p. 5, pl. 1, fig. 8. - Loeblich and Tappan, 1953, Smithsonian Misc. Coll., v. 121, no. 7, p. 99-100, pl. 18, figs. 4-9. - McDougall and others, 1986, U.S. Geological Survey Bull. 1598, p. 53, pl. 2, figs. 5, 9. - This paper, pl. 2, fig. 7.

Elphidium cf. E. frigidum Cushman - Aberrant forms that have characteristics similar to $E$. frigidum.

Elphidium incertum (Williamson) - Loeblich and Tappan, 1953, Smithsonian Misc. Coll., v. 121, no. 7, p. 100-102. - McDougall and others, 1986, U.S. Geological Survey Bull. 1598, p. 53, pl. 2, fig. 7. - This paper, pl. 2, fig. 9.

Elphidium cf. E. incertum (Williamson) - These specimens exhibit some but not all of the distinguishing characteristics of Elphidium incertum.

Elphidium nanum Vilks = Protelphidium nanum Vilks - Vilks and others, 1979, Geological Survey of Canada Bull., v. 303, p. 35, pl. 1, figs. 1-4. - This paper, pl. 2, fig. 8 .

Elphidium orbiculare (Brady) - Loeblich and Tappan, 1953, Smithsonian Misc. Coll., v. 121, no. 7, p. 102-103, pl. 19, figs. 1-4. - McDougall and others, 1986, U.S. Geological Survey Bull. 1598, p. 53, pl. 2, fig. 10. - This paper, pl. 2, fig. 10.

Elphidium sp. - Small specimens that are probably juveniles.

Elphidium spp. - These specimens are broken or poorly preserved individuals of Elphidium.

Elphidium ustulatum Todd, 1957, U.S. Geological Survey Prof. Paper 294-F, p. 230-231, pl. 28, fig. 16. - Cribroelphidium ustulatum (Todd) - McNeil, 1989, Geological Survey of Canada Paper 89-1G, p. 213-215, pl. 1, fig. 2. - This paper, pl. 2, figs. 11, 12 .

Elphidium cf. E. ustulatum Todd - Poorly preserved individuals that resemble $E$. ustulatum.

Entosolenia spp. - These specimens are juveniles of unknown species of Entosolenia.

Epistominella arctica Green, 1959, U.S. Air Force Cambridge Research Center, Geophysics Research Papers, v. 1, p. 78-79, pl. 1, fig. 4.

Epistominella vitrea Parker, 1953, Cushman Foundation for Foraminiferal Research, Spec. Pub. 2, p. 9, pl. 4, figs. 34-36.

Esosyrinx curta (Cushman and Ozawa) = Pseudopolymorphina curta Cushman and Ozawa, 1930, U.S. National Museum Proceedings, v. 77, art. 6, p. 105, pl. 27, fig. 3. = Esosyrinx curta (Cushman and Ozawa) - Loeblich and Tappan, 1953, Smithsonian Misc. Coll., v. 121, no. 7, p. 85-86, pl. 15, figs. 1-5. - McDougall and others, 1986, U.S. Geological Survey Bull. 1598 , p. 53, pl. 2, fig. 11.

Fissurina cucullata Silvestri - Parker, 1964, Jour. of Paleontology, v. 38, p. 625 , pl. 98 , fig. 7.

Fissurina cucurbitasema Loeblich and Tappan, 1953, Smithsonian Misc. Coll., v. 121, no. 7, p. 76, pl. 14, figs. 10-11.

Fissurina danica (Madsen) - Feyling-Hanssen, 1971, Geological Society of Denmark Bull., v. 21, p. 228, pl. 6, figs. 6-7. This paper, pl. 3, fig. 1.

Fissurina lucida (Williamson) - Loeblich and Tappan, 1953, Smithsonian Misc. Coll., v. 121, no. 7, p. 76-77, pl. 14, fig. 4.
Fissurina marginata (Montagu) - Loeblich and Tappan, 1953 Smithsonian Misc. Coll., v. 121, no. 7, p. 77, pl. 14, figs. 6-9. - McDougall and others, 1986, U.S. Geological Survey Bull. 1598, p. 53, pl. 2, fig. 12.

Fissurina semimarginata (Reuss) - Loeblich and Tappan, 1953, Smithsonian Misc. Coll., v. 121, no. 7, p. 78, pl. 14, fig. 3. This paper, pl. 3, fig. 2.

Fissurina spp. - Broken and poorly preserved specimens that cannot be identified to species.

Fissurina serrata (Schlumberger) - Loeblich and Tappan, 1953, Smithsonian Misc. Coll., v. 121, no. 7, p. 78, pl. 14, fig. 5. This paper, pl. 3, fig. 3 .

Fissurina ventricosa (Wiesner) - Loeblich and Tappan, 1953, Smithsonian Misc. Coll., v. 121, no. 7, p. 79, pl. 14, fig. 15.

Fursenkoina loeblichi (Feyling-Hanssen) = Virgulina loeblichi Feyling-Hanssen, 1971, Geological Society of Denmark Bull., v. 21, p. 238, pl. 7, figs. 1-5. - This paper, pl. 3, fig. 4.

Fursenkoina schreibersiana $($ Czjzek) = Virgulina schreibersiana Czjzek - Feyling-Hanssen, 1971, Geological Society of Denmark Bull., v. 21 , p. 240 , pl. 7 , figs. 6-8.

Glandulina laevigata (d'Orbigny) - Loeblich and Tappan, 1953, Smithsonian Misc. Coll., v. 121, no. 7, p. 81-82, pl. 16, figs. 2-5. - McDougall and others, 1986, U.S. Geological Survey Bull. 1598, p. 53. - This paper, pl. 3, fig. 5.

Globulina inaequalis Reuss - Feyling-Hanssen, 1971, Geological Society of Denmark Bull., v. 21, p. 216, pl. 5, fig. 3.

Globulina landesi (Hanna and Hanna) - Feyling-Hanssen, 1971, Geological Society of Denmark Bull., v. 21, p. 217, pl. 5, fig. 4.

Globulina sp. - These specimens can be subdivided into two groups: Those of the first group may be variants, and those of the second group are juveniles of one of the Globulina species named above.

Gordiospira arctica Cushman, 1933, Smithsonian Misc. Coll., v. 89, no. 9, p. 3, pl. 1, figs. 5-7. - Loeblich and Tappan, 1953, Smithsonian Misc. Coll., v. 121, no. 7, p. 49-50, pl. 7, figs. 13. - McDougall and others, 1986, U.S. Geological Survey Bull. 1598, p. 53, pl. 3, figs. 2, 3. - This paper, pl. 3, fig. 6.

Guttulina austriaca d'Orbigny - Feyling-Hanssen, 1971, Geological Society of Denmark Bull., v. 21, p. 211-212, pl. 4, figs. 8, 9. - McDougall and others, 1986, U.S. Geological Survey Bull. 1598, p. 53.

Guttulina dawsoni Cushman and Ozawa, 1930, U.S. National Museum Proceedings, v. 77, art. 6, p. 47-48, pl. 12, figs. 1, 2. - This paper, pl. 3, fig. 7 .

Guttulina glacialis (Cushman and Ozawa) - Feyling-Hanssen, 1971, Geological Society of Denmark Bull., v. 21, p. 213, pl. 4, figs. 11-13. - This paper, pl. 3, fig. 8.

Guttulina lactea (Walker and Jacob) - Feyling-Hanssen, 1971, Geological Society of Denmark Bull., v. 21, p. 214, pl. 4, figs. 14-18. - McDougall and others, 1986, U.S. Geological Survey Bull. 1598, p. 53, pl. 3, fig. 4.

Guttulina problema d'Orbigny - Feyling-Hanssen, 1971, Geological Society of Denmark Bull., v. 21, p. 215, pl. 5, figs. 1, 2. - McDougall and others, 1986, U.S. Geological Survey Bull. 1598, p. 53.

Guttulina sp. - These specimens can be subdivided into two groups: Variants, and juveniles of one of the above-named species of Guttulina.

Lagena costata (Williamson) = Oolina costata (Williamson) Loeblich and Tappan, 1953, Smithsonian Misc. Coll., v. 121, 
no. 7 , p. 68 , pl. 13 , figs. 4-6. = Lagena costata (Williamson) - McDougall and others, 1986, U.S. Geological Survey Bull. 1598, p. 53, pl. 3, fig. 5. - This paper, pl. 3, fig. 9.

Lagena distoma Parker and Jones - Chapman and Parr, 1937, Australasian Antarctic Exped. 1911-1914, Sci. Repts., ser. C (Zool. Bot.), v. 1, p. 65, pl. 7, fig. 7.

Lagena gracilis Williamson, 1848, Natural History Annual Mag., ser. 2 , v. 1, p. 13, pl. 1, fig. 5.

Lagena gracillima (Sequenza) - Loeblich and Tappan, 1953, Smithsonian Misc. Coll., v. 121, no. 7, p. 60-61, pl. 11, figs. 1-4. - McDougall and others, 1986, U.S. Geological Survey Bull. 1598, p. 53, pl. 3, fig. 6. - This paper, pl. 3, fig. 10.

Lagena hexagona (Williamson) = Oolina hexagona (Williamson) - Loeblich and Tappan 1953, Smithsonian Misc. Coll., v. 121, no. 7 , p. 69 , pl. 14, figs. 1,2 . - McDougall and others, 1986 , U.S. Geological Survey Bull. 1598, p. 54. - This paper, pl. 3, fig. 11.

Lagena laevis (Montagu) - Loeblich and Tappan, 1953, Smithsonian Misc. Coll., v. 121, no. 7, p. 61-62, pl. 11, figs. 5-8. - This paper, pl. 3, fig. 12.

Lagena mollis Cushman - Loeblich and Tappan, 1953, Smithsonian Misc. Coll., v. 121, no. 7, p. 63-64, pl. 11, figs. 25-27. - This paper, pl. 3, fig. 13.

Lagena parri Loeblich and Tappan, 1953, Smithsonian Misc. Coll., v. 121, no. 7, p. 64, pl. 11, figs. 11-13.

Lagena sulcata laevicosta Cushman and Gray - Feyling-Hanssen, 1971, Geological Society of Denmark Bull., v. 21, p. 210, pl. 4, figs. 4-5.

Lagena sp. - These specimens are juveniles of various species of Lagena. - This paper, pl. 3, fig. 14.

Laryngosigma hyalascidia Loeblich and Tappan, 1953, Smithsonian Misc. Coll., v. 121, no. 7, p. 83-84, pl. 15, figs. 6-8.

Melonis zaandamae (van Voorthuysen) = Nonion zaandamae (van Voorthuysen) - Loeblich and Tappan, 1953, Smithsonian Misc. Coll., v. 121, no. 7, p. 87-90, pl. 16, figs. 11, 12. - This paper, pl. 4, fig. 1.

Miliolinella chukchiensis Loeblich and Tappan, 1953, Smithsonian Misc. Coll., v. 121 , no. 7 , p. 47, pl. 6, fig. 7. - This paper, pl. 3, fig. 15.

Nodosaria spp. - These specimens are juveniles.

Nonion sp. - Specimens are juveniles that cannot be identified to species.

Nonionella auricula Heron-Allen and Earland - Loeblich and Tappan, 1953, Smithsonian Misc. Coll., v. 121, no. 7, p. 9293, pl. 16, figs. 6-10. - This paper, pl. 4, fig. 2.

Nonionella labradorica (Dawson) - Feyling-Hanssen, 1971, Geological Society of Denmark Bull., v. 21, p. 262, pl. 10, figs. 1, 2. - Loeblich and Tappan, 1953, Smithsonian Misc. Coll., v. 121 , no. 7 , p. $86-87$, pl. 17, figs. $1,2$.

Nonionella sp. - Specimens are juveniles.

Oolina caudigera (Wiesner) - Loeblich and Tappan, 1953, Smithsonian Misc. Coll., v. 121, no. 7, p. 67-68, pl. 13, figs. 1-3.

Oolina lineata (Williamson) - Loeblich and Tappan, 1953, Smithsonian Misc. Coll., v. 121, no. 7, p. 70, pl. 13, figs. 1113. - McDougall and others, 1986, U.S. Geological Survey Bull. 1598, p. 54, pl. 3, fig. 8.

Oolina lineatopunctata (Heron-Allen and Earland) - Loeblich and Tappan, 1953, Smithsonian Misc. Coll., v. 121, no. 7, p. 70-71, pl. 13, fig. 8. - This paper, pl. 4, fig. 3.
Oolina melo d'Orbigny - Loeblich and Tappan, 1953, Smithsonian Misc. Coll., v. 121, no. 7, p. 71-72, pl. 12, figs. 8-15. McDougall and others, 1986, U.S. Geological Survey Bull. 1598, p. 54. - This paper, pl. 4, fig. 4.

Oolina sp. - These specimens are juveniles.

Parafissurina arctica Green, 1959, U.S. Air Force Cambridge Research Center, Geophysics Research Papers, v. 1, p. 76-78, pl. 1, figs. 2a, b.

Parafissurina fusuliformis Loeblich and Tappan, 1953, Smithsonian Misc. Coll., v. 121, no. 7, p. 79-80, pl. 14, figs. 18, 19.

Parafissurina lateralis carinata Buchner - Feyling-Hanssen, 1971, Geological Society of Denmark Bull., v. 21, p. 233, pl. 6, figs. 12, 13. - McDougall and others, 1986, U.S. Geological Survey Bull. 1598, p. 54.

Parafissurina sp. - Specimens could not be identified to species.

Parafissurina tectulostoma Loeblich and Tappan, 1953, Smithsonian Misc. Coll., v. 121, no. 7, p. 81, pl. 14, fig. 17.

Pateoris hauerinoides (Rhumbler) - Loeblich and Tappan, 1953, Smithsonian Misc. Coll., v. 121, no. 7, p. 42-45, pl. 6, figs. 812, tf. 1. - McDougall and others, 1986, U.S. Geological Survey Bull. 1598, p. 54, pl. 3, fig. 10. - This paper, pl. 4, fig. 5.

Polymorphina suboblonga $($ Cushman and Ozawa $)=$ Pseudopolymorphina suboblonga Cushman and Ozawa, 1930, U.S., National Museum Proceedings, v. 77, art. 6, p. 91, pl. 23, fig. 3 . = Polymorphina suboblonga (Cushman and Ozawa) - McDougall and others, 1986, U.S. Geological Survey, Bull. 1598, p. 54, pl. 3, figs. 11-13. - This paper, pl. 4, fig. 6.

Polymorphina spp. - Specimens are broken or poorly preserved and cannot be identified to species.

Pseudopolymorphina novangliae (Cushman) - Feyling-Hanssen, 1971, Geological Society of Denmark Bull., v. 21, p. 217, pl. 5, figs. 5, 6 .

Pseudopolymorphina soldanii (d'Orbigny) - Feyling-Hanssen, 1971, Geological Society of Denmark Bull., v. 21, p. 218, pl. 5 , fig. 7.

Pullenia sp. - Specimens are juveniles.

Pyrgo williamsoni (Silvestri) - Loeblich and Tappan, 1953, Smithsonian Misc. Coll., v. 121, no. 7, p. 48-49, pl. 6, figs. 14. - McDougall and others, 1986, U.S. Geological Survey Bull. 1598, p. 54, pl. 4, fig. 2.

Pyrulina cylindroides (Roemer) = Polymorphina (Polymorphien) cylindroides Roemer, 1938, Neues Jahrb. Mineral. Geogn. Geol. Petref.-Kunde, p. 385, pl. 3, figs. 27a, b.

Quinqueloculina agglutinata Cushman - Cushman and Valentine, 1930, Stanford University, Dept. of Geology Contributions, v. 1, p. 9-10, pl. 1, fig. 7.

Quinqueloculina arctica Cushman, 1933, Smithsonian Misc. Coll., v. 89, no. 9, p. 2, pl. 1, fig. 3. - Loeblich and Tappan, 1953, Smithsonian Misc. Coll., v. 121, no. 7, p. 40, pl. 5, figs. 11, 12. - McDougall and others, 1986, U.S. Geological Survey Bull. 1598 , p. 54 , pl. 4 , fig. 3. - This paper, pl. 4, fig. 7.

Quinquelocülina seminulum (Linne) - Feyling-Hanssen, 1971, Geological Society of Denmark Bull., v. 21, p. 194, pl. 1, figs. 18-20. - McDougall and others, 1986, U.S. Geological Survey Bull. 1598 , p. 54, pl. 4, fig. 4. - This paper, pl. 4, fig. 8.

Quinqueloculina spp. - Specimens are broken or poorly preserved individuals.

Quinqueloculina stalkeri Loeblich and Tappan, 1953, Smithsonian Misc. Coll., v. 121 , no. 7, p. $40-41$, pl. 5, figs. 5-9. - 
McDougall and others, 1986, U.S. Geological Survey Bull. 1598, p. 54. - This paper, pl. 4, fig. 9.

Reophax curtus Cushman, 1920, U.S. National Museum Bull., v. 104, pt. 2, p. 8-9, pl. 2, figs. 2, 3. - Loeblich and Tappan, 1953, Smithsonian Misc. Coll., v. 121, no. 7, p. 22-23, pl. 2, figs. $1-4$.

Reophax spp. - Specimens are broken or poorly preserved. This paper, pl. 4, fig. 10.

Scutuloris tegminis Loeblich and Tappan, 1953, Smithsonian Misc. Coll., v. 121, no. 7, p. 41-42, pl. 5, fig. 10. - McDougall and others, 1986, U.S. Geological Survey Bull. 1598, p. 55. - This paper, pl. 4, fig. 11.

Sigmomorphina sp. - A single specimen that cannot be identified to species.

Spiroplectammina biformis (Parker and Jones) - Loeblich and Tappan, 1953, Smithsonian Misc. Coll., v. 121, no. 7, p. 34 35, pl. 4, figs. 1-6. - This paper, pl. 4, fig. 12.

Stainforthia concava (Hoeglund) = Bulimina exilis Brady Loeblich and Tappan, 1953, Smithsonian Misc. Coll., v. 121, no. 7 , p. 110 , pl. 20 , figs. $4,5 .=$ Stainforthia concava (Hoeglund) - McDougall and others, 1986, U.S. Geological Survey Bull. 1598, p. 55, pl. 4, fig. 9. - This paper, pl. 4, fig. 13. Triloculina trihedra Loeblich and Tappan, 1953, Smithsonian Misc. Coll., v. 121, no. 7, p. 45, pl. 4, fig. 10. - McDougall and others, 1986, U.S. Geological Survey Bull. 1598, p. 55, pl. 4, fig. 10.

Trochammina rotaliformis Wright - Loeblich and Tappan, 1953, Smithsonian Misc. Coll., v. 121, no. 7, p. 51-52, pl. 8, figs. 69. - McDougall and others, 1986, U.S. Geological Survey Bull. 1598, p. 55, pl..4, fig. 12. - This paper, pl. 4, fig. 14.

Trochammina sp. - These specimens could not be identified to genus.

Trochamminella atlantica Parker, in Parker and others, 1953, Jour. of Paleontology, v. 38, p. 409, pl. 4, figs. 17-19. - Loeblich and Tappan, 1953, Smithsonian Misc. Coll., v. 121, no. 7, p. 52, pl. 7, figs. 6, 7 .

Valvulineria arctica Green, 1959, U.S. Air Force Cambridge Research Center, Geophysics Research Papers, v. 1, p. 76-78, pl. 1, figs. 3a-c. 


\section{INDEX}

\section{A}

advena, Eggerella, 11, 34, 44, 76, 81, 93; pl. 1 agglutinata, Quinqueloculina, 11, 76, 95 alba, Elphidium excavatum, 1, 10, 11, 25, 29,

$34,35,38,41,47,49,53,54,57,58,59$, $62,65,70,71,72,73,74,75,76,78,79$, $80,81,82,84,86,88,94$; pl. 2

albiumbilicatum,

Elphidium, 11, 18, 21, 22, 44, 47, 49, 54, 71, $72,73,74,75,76,78,80,81,82,84$, $86,88,93$; pl. 2

Nonion pauciloculum, 93

Alveolophragmium

crassimargo, 11

jeffreysii, 11

Ammodiscus minutissimus, 11

Ammotium cassis, 21, 73, 93

Anaktuvuk River glaciation, 3

Anvillian, 1, 3, 4, 5, 6, 7, 8, 47, 48, 49, 50, 57, 58

arctica,

Epistominella, 11, 18, 19, 53, 72, 86, 94

Gordiospira, 11, 44, 72, 73, 74, 75, 81, 82, $84,88,94 ;$ pl. 3

Parafissurina, 74, 75, 95

Quinqueloculina, 70, 71, 73, 81, 82, 84, 88, 95; pl. 4

Reophax, 11

Valvulineria, 74, 96

asklundi,

Elphidium, 1, 10, 39, 44, 58, 59, 62, 71, 72, $73,74,75,76,78,79,80,81,82,84$, $86,88,93$; pl. 2

Astracolus hyalacrulus, 72, 86, 93

Astrononion gallowayi, 11, 54, 73, 75, 78, 86, 88, 93

atlantica, Trochamminella, 39, 71, 80, 81, 96 auricula, Nonionella, 11, 54, 71, 72, 75, 76, 86, 95; pl. 4

austriaca, Guttulina, 75, 82, 84, 86, 94

\section{B}

baccata,

Discorbina, 93

Discorbis, 11, 71, 72, 73, 74, 75, 79, 82, 86, 88,$93 ; \mathrm{pl} .1$

baggi, Dentalina, 70, 71, 73, 76, 78, 81, 93 bartletti,

Elphidium, 11, 44, 70, 71, 72, 73, 74, 75, 76, $78,79,80,82,84,86,88,93$; pl. 2

Beringian, 1, 3, 4, 5, 6, 7, 8, 47, 48, 49, 50, 57 , 58

biformis, Spiroplectammina, 11, 18, 21, 22, 72 , 73,$96 ; \mathrm{pl} .4$

Bigbendian, 3, 5

Bolivina

pacifica, 11

pseudopunctata, 42, 44, 81, 93

sp., 82, 93 bradii,

llyocypris, 39

Sarsicytheridea, 16

Brunhes Normal-Polarity Chron, 3

Brunlow Point unit, 6, 7, 8, 47, 48, 54

brunnescens, Elphidiella?, 50, 84, 93; pl. 1

Buccella

frigida, 11, 13, 14, 15, 17, 18, 19, 20, 21, 22 , $23,24,25,28,30,31,33,34,36,37$, $38,39,41,42,43,44,45,46,47,49$, $50,51,53,54,56,57,58,70,71,72$, $73,74,75,76,78,79,80,81,82,84$, $86,88,93 ; \mathrm{pl}$. 1

inusitata, 50, 72, 73, 74, 79, 80, 81, 84, 88, 93

sp., $36,75,93$

Bulimina exilis, 96

bullata, Trochammina, 11

\section{C}

\section{Camden Bay unit, 6, 7, 8, 47, 48, 57 \\ Candona \\ rectangulata, 39 \\ sp., 22}

carinata, Parafissurina lateralis, 81, 84, 95

Cassidulina

crassa, 11, 18, 49, 51, 54, 72, 76, 84, 86, 88 , 93

islandica, 11, 14, 15, 16, 17, 18, 19, 20, 21 , $22,24,25,28,30,31,33,34,36,38$ $39,41,43,46,49,53,54,56,71,72$, $73,74,75,76,78,79,80,81,82,84$, $86,88,93$; pl. 1

norcrossi, 11, 12, 13, 14, 15, 16, 17, 18, 19 , $20,21,22,24,25,28,31,33,34,36$, $38,39,41,43,44,46,47,49,53,54$, $56,70,71,72,73,74,75,76,78,79$ $80,81,82,84,86,88,93 ;$ pl. 1 teretis, 11

cassidulinids, $11,13,18,21,25,30,34,38,39$, $42,44,45,50,51,54,57,59$

cassis, Ammotium, 21, 73, 93

caudigera, Oolina, 73, 75, 81, 95

chukchiensis, Miliolinella, 49, 75, 78, 79, 81, $82,84,86,88,95 ;$ pl. 3

Cibicides

lobatulus, 11, 71, 76, 84, 88, 93; pl. 1

mckannai, 81, 93

sp., 86, 93

Cibicidoides Assemblage Zone, 50

clavatum, Elphidium, 4, 6, 8, 10, 11, 13, 14, 15 , $16,17,18,19,21,22,24,25,28,30,31$, $33,34,35,36,38,39,41,43,44,45,46$ $47,49,50,51,53,54,56,57,58,65,70$, $71,72,73,74,75,76,78,79,80,81,82$, $84,86,88,93$; pl. 2

Colvillian, 3, 4

complanata, Stainforthia, 11 concava, Stainforthia, 11, 14, 15, 18, 19, 20, 21 , $31,33,34,42,43,44,45,49,51,53,54$, $56,57,71,72,73,75,76,81,82,84,86$, 88, 96; pl. 4

Cornuspira involvens, 93

corrugata, Patellina, 11

costata,

Lagena, 72, 73, 76, 86, 94, 95; pl. 3

Oolina, 94

crassa, Cassidulina, 11, 18, 49, 51, 54, 72, 76 , $84,86,88,93$

crassimargo, Alveolophragmium, 11

Cribroelphidium ustulatum, 93

Cross Island unit, 6, 7, 8, 10, 25, 26, 27, 29, 30, $31,32,34,35,39,41,42,44,45,47,48$, $54,55,57,60,62,63,64,65$

cucullata, Fissurina, 82, 94

cucurbitasema, Fissurina, 75, 94

curta,

Esosyrinx, 78, 81, 94

Pseudopolymorphina, 94

curtus, Reophax, 11, 39, 80, 96

Cyclammina spp., 76, 93

Cyclogyra involvens, $11,71,73,74,76,78,81$, $82,84,88,93$; pl. 1

cylindroides

Polymorphina (Polymorphien), 95

Pyrulina, 74, 75, 78, 79, 86, 88, 95

\section{D}

danica, Fissurina, 76, 88, 94; pl. 3

dawsoni, Guttulina, 72, 75, 80, 82, 84, 86, 88 , 94; pl. 3

Dentalina

baggi, 70, 71, 73, 76, 78, 81, 93

frobisherensis, 70, 71, 72, 76, 78, 81, 84, 93; pl. 1

ittai, $71,80,82,84,86,88,93$; pl. 1

pauperata, 84,93 ; pl. 1

spp., 76, 88, 93

digitata, Nonionella, 11

Discorbina baccata, 93

Discorbis baccata, 11, 71, 72, 73, 74, 75, 79, $82,86,88,93$; pl. 1

distoma, Lagena, 78, 95

Duchess sand unit, $6,7,8,9,30,32,47,48,49$, $51,54,55,60$

$\mathbf{E}$

Eggerella advena, 11, 34, 44, 76, 81, 93; pl. 1 Elphidiella groenlandica, 1, 10, 11, 12, 13, 14, $39,44,58,59,62,70,71,72,73,74,75$, $76,80,81,82,84,86,88,93$; pl. 1

Elphidiella? brunnescens, 50, 84, 93; pl. 1 Elphidium

albiumbilicatum, 11, 18, 21, 22, 44, 47, 49, $54,71,72,73,74,75,76,78,80,81,82$, $84,86,88,93$; pl. 2 
Elphidium-Continued

asklundi, 1, 10, 39, 44, 58, 59, 62, 71, 72, $73,74,75,76,78,79,80,81,82,84$, $86,88,93 ; \mathrm{pl} .2$

bartletti, 11, 44, 70, 71, 72, 73, 74, 75, 76, $78,79,80,82,84,86,88,93 ;$ pl. 2

clavatum, 4, 6, 8, 10,11, 13, 14, 15, 16, 17 , $18,19,21,22,24,25,28,30,31,33$, $34,35,36,38,39,41,43,44,45,46$, $47,49,50,51,53,54,56,57,58,65$, $70,71,72,73,74,75,76,78,79,80$, $81,82,84,86,88,93 ;$ pl. 2 excavatum alba, 1, 10, 11, 25, 29, 34, 35, $38,41,47,49,53,54,57,58,59,62$, $65,70,71,72,73,74,75,76,78,79$, $80,81,82,84,86,88,94$; pl. 2

frigidum, 34, 36, 44, 71, 72, 73, 75, 76, 78, $79,80,81,84,94 ;$ pl. 2

groenlandicum, 93

incertum, 1, 11, 12, 13, 14, 15, 17, 18, 19 , $20,21,24,25,28,29,31,33,34,36$, $38,39,41,43,44,45,46,47,49,50$, $51,53,54,56,57,58,59,70,71,72$, $73,74,75,76,78,79,80,81,82,84$, $86,88,94$; pl. 2

nanum, $34,35,71,72,73,74,75,76,78,79$, $80,81,84,86,88,94 ;$ pl. 2

orbiculare, $4,6,11,12,13,14,15,17,18$, $19,21,22,24,28,30,31,33,34,35$, $36,38,39,41,43,44,46,49,51,53$, $54,56,57,58,70,71,72,73,74,75$, $76,78,79,80,81,82,84,86,88,94$; pl. 2

sp., 71, 72, 73, 94

spp., $12,13,35,70,71,72,73,75,76,78$, $79,80,81,82,84,86,88,94$ ustulatum, 1, 5, 50, 57, 58, 84, 86, 94; pl. 2 elphidiums, $11,12,13,14,18,20,21,22,25$, $30,34,37,38,39,44,45,47,50,51,54$, $57,58,59,61$

Entosolenia spp., 73, 94

Epistominella

arctica, 11, 18, 19, 53, 72, 86, 94

vitrea, $18,19,31,33,34,43,44,53,54,56$, $57,70,72,74,75,76,81,86,88,94$

Esosyrinx curta, 78, 81, 94

Eucypris foveata, 39

excavatum alba, Elphidium, 1, 10, 11, 25, 29 , $34,35,38,41,47,49,53,54,57,58$, $59,62,65,70,71,72,73,74,75,76$, $78,79,80,81,82,84,86,88,94$; pl. 2

exilis, Bulimina, 96

\section{$\mathbf{F}$}

Fishcreekian, 1, 3, 4, 5, 7, 8, 14, 16, 47, 48, 49, $50,57,58$

Fissurina, 14, 20, 25, 34, 57

cucullata, 82, 94

cucurbitasema, 75, 94

danica, 76, 88, 94; pl. 3

lucida, 76, 78, 94

marginata, $71,73,75,76,78,82,84,86,88$, 94

semimarginata, $76,88,94 ;$ pl. 3

spp., 74, 75, 76, 82, 86, 94

serrata, 73, 75, 84, 94; pl. 3
Fissurina-Continued

ventricosa, 71, 74, 88, 94

fissurinids, 30

Flandrian, 1, 3, 4, 6, 7, 8, 10, 12, 13, 14, 15, 16 $17,18,19,20,21,22,23,25,26,27,28$, $29,30,31,32,33,37,38,39,40,41,42$, $43,45,46,47,48,49,51,52,53,57,64$, 65

Flaxman Member, 10

foveata, Eucypris, 39

frigida,

Buccella, 11, 13, 14, 15, 17, 18, 19, 20, 21, $22,23,24,25,28,30,31,33,34,36$, $37,38,39,41,42,43,44,45,46,47$, $49,50,51,53,54,56,57,58,70,71$ $72,73,74,75,76,78,79,80,81,82$, $84,86,88,93$; pl. 1

Pulvinulina, 93

frigidum, Elphidium, 34, 36, 44, 71,72, 73, 75, $76,78,79,80,81,84,94$; pl. 2

frobisherensis, Dentalina, 70, 71, 72, 76, 78, 81, 84,$93 ;$ pl. 1

Fursenkoina

loeblichi, 76, 94; pl. 3

schreibersiana, 57, 71, 81, 82, 84, 88, 94

fusca, Psammospheara, 11

fusiformis, Stainforthia, 11

fusuliformis, Parafissurina, 76, 95

\section{G}

gallowayi, Astrononion, 11, 54, 73, 75, 78, 86, 88, 93

Gauss Normal-Polarity Chron, 3

Gilbert Reversed Normal-Polarity Chron, 3 glacialis,

Guttulina, 70, 71, 72, 73, 74, 75, 76, 79, 84, Krithe, 38 $86,88,94$; pl. 3

Glandulina, 57

laevigata, 76, 80, 81, 82, 84, 88, 94; pl. 3

Globulina

inaequalis, 88, 94

landesi, 75,94

sp., $74,76,84,88,94$

Gordiospira, 11

arctica, $11,44,72,73,74,75,81,82,84,88$ $94 ;$ pl. 3

gracilis, Lagena, 72, 95

gracillima, Lagena, $71,72,75,76,78,82,84$, $86,88,95$; pl. 3

groenlandica, Elphidiella, 1, 10, 11, 12, 13, 14, $39,44,58,59,62,70,71,72,73,74,75$, $76,80,81,82,84,86,88,93$; pl. 1

groenlandicum, Elphidium, 93

Gubik Formation, 10

Gunsight Mountain glaciation, 3

guttifer, Reophax, 11

Guttulina, 57, 94

austriaca, 75, 82, 84, 86, 94

dawsoni, $72,75,80,82,84,86,88,94 ;$ pl. 3

glacialis, $70,71,72,73,74,75,76,79,84$, $86,88,94$; pl. 3

lactea, 75, 76, 78, 80, 81, 84, 86, 94

problema, 88, 94

sp., $70,71,72,73,74,76,80,81,82,84,86$, 94

\section{$\mathbf{H}$}

hauerinoides, Pateoris, 71, 74, 75, 84, 86, 88, 95; pl. 4

hexagona,

Lagena, 76, 80, 82, 95; pl. 3

Oolina, 95

hyalacrulus, Astracolus, 72, 86, 93

hyalascidia, Laryngosigma, 75, 76, 82, 95

I

Ilyocypris bradii, 39

inaequalis, Globulina, 88, 94

incertum, Elphidium, 1, 11, 12, 13, 14, 15, 17 , $18,19,20,21,24,25,28,29,31,33,34$. $36,38,39,41,43,44,45,46,47,49,50$, $51,53,54,56,57,58,59,70,71,72,73$, $74,75,76,78,79,80,81,82,84,86,88$, 94; pl. 2

inusitata, Buccella, 50, 72, 73, 74, 79, 80, 81 . $84,88,93$

involvens,

Cornuspira, 93

Cyclogyra, 11, 71, 73, 74, 76, 78, 81, 82, 84, 88,$93 ;$ pl. 1

islandica, Cassidulina, 11, 14, 15, 16, 17, 18, $19,20,21,22,24,25,28,30,31,33$, $34,36,38,39,41,43,46,49,53,54$, $56,71,72,73,74,75,76,78,79,80$ $81,82,84,86,88,93$; pl. 1

Itkillik glaciation, 3, 4

Itkillik I, 4, 5

Itkillik II, 4, 5

ittai, Dentalina, 71, 80, 82, 84, 86, 88, 93; pl. 1

$\mathbf{J}$

jeffreysii, Alveolophragmium, 11

$\mathbf{K}$

Kotzebuan, 4

Krithe glacialis, 38

$\mathbf{L}$

labradorica, Nonionella, 11, 88, 95 lactea, Guttulina, 75, 76, 78, 80, 81, 84, 86, 94

laevicosta, Lagena sulcata, 76, 86, 95

laevigata, Glandulina, 76, 80, 81, 82, 84, 88, 94; pl. 3

laevis, Lagena, 71, 76, 78, 84, 86, 88, 95; pl. 3

Lagena, 14, 20, 25, 34

costata, $72,73,76,86,94,95 ;$ pl. 3

distoma, 78, 95

gracilis, 72,95

gracillima, $71,72,75,76,78,82,84,86,88$. 95 ; pl. 3

hexagona, 76, 80,82,95; pl. 3

laevis, $71,76,78,84,86,88,95 ;$ pl. 3

mollis, 73, 76, 95; pl. 3

parri, 84, 95

sulcata laevicosta, 76, 86, 95

sp., $71,76,78,82,88,95 ;$ pl. 3

lagenids, 50

landesi, Globulina, 75, 94 
Laryngosigma hyalascidia, 75, 76, 82, 95 lateralis carinata, Parafissurina, 81, 84, 95 Leffingwell Lagoon unit, 6, 7, 8, 9, 10, 25, 27 , $29,30,31,32,39,41,42,44,45,47,48$ $51,52,54,55,57,58,60,62,63$

\section{Limnocythere}

liporeticulata, 39

platyforma, 39

lineata, Oolina, 79, 95

lineatopunctata, Oolina, 76, 82, 95; pl. 4

liporeticulata, Limnocythere, 39

lobatulus, Cibicides, 11, 71, 76, 84, 88, 93; pl. 1 loeblichi,

Fursenkoina, 76, 94; pl. 3

loeblichi-Continued

Virgulina, 94

lucida, Fissurina, 76, 78, 94

\section{M}

Maguire Islands unit, 6, 7, 8, 9, 10, 25, 26, 27 $29,30,31,32,34,35,36,37,39,40,41$, $42,44,45,48,51,52,54,55,57,59,60$, $62,63,64,65$

marginata, Fissurina, 71, 73, 75, 76, 78, 82, 84, $86,88,94$

Matuyama Reversed-Polarity Chron, 3, 5

mckannai, Cibicides, 81, 93

melo, Oolina, 76, 95; pl. 4

Melonis zaandamae, 11, 49, 50, 84, 95; pl. 4

middle Wisconsin, 1, 3, 4, 5, 7, 8, 10, 29, 30, 31, $52,53,54,57,62,63$

Mikkelsen Bay unit, 6, 7, 8, 10, 29, 30, 51, 52, 57,62

miliolids, 11

Miliolinella chukchiensis, 49, 75, 78, 79, 81, 82 , $84,86,88,95$; pl. 3

minutissimus, Ammodiscus, 11

mollis, Lagena, 73, 76, 95; pl. 3

\section{$\mathbf{N}$}

nana, Trochammina, 11

nanum,

Elphidium, 34, 35, 71, 72, 73, 74, 75, 76, 78, $79,80,81,8486,88,94$; pl. 2

Protelphidium, 94

Newport sand unit, 6, 7, 8, 39, 40

Nodosaria spp., 86, 95

Nonion

pauciloculum albiumbilicatum, 93

sp., 71, 76, 88, 95

zaandamae, 95

Nonionella

auricula, 11, 54, 71, 72, 75, 76, 86, 95; pl. 4 digitata, 11

labradorica, 11, 88, 95

sp., 12, 30, 70, 75, 95

norcrossi, Cassidulina, 11, 12, 13, 14, 15, 16

$17,18,19,20,21,22,24,25,28,31$, $33,34,36,38,39,41,43,44,46,47$ $49,53,54,56,70,71,72,73,74,75$, $76,78,79,80,81,82,84,86,88,93$; pl. 1

North Star sand unit, 6, 7, 8, 30, 32, 47, 48 novangliae,

Pseudopolymorphina, 76, 88, 95

Nuwok Member, 50

\section{$\mathbf{0}$}

oblongata, Triloculina, 11

Oolina, 20

caudigera, $73,75,81,95$

costata, 94

hexagona, 95

lineata, 79, 95

lineatopunctata, 76, 82, 95; pl. 4

melo, 76, $95 ; \mathrm{pl} .4$

sp., 76,95

orbiculare, Elphidium, 4, 6, 11, 12, 13, 14, 15 ,

$17,18,19,21,22,24,28,30,31,33,34$, $35,36,38,39,41,43,44,46,49,51,53$, $54,56,57,58,70,71,72,73,74,75,76$, $78,79,80,81,82,84,86,88,94 ;$ pl. 2

\section{$\mathbf{P}$}

pacifica, Bolivina, 11

Paracyprideis pseudopunctillata, 17, 38

Parafissurina, 34 arctica, 74, 75, 95

fusuliformis, 76, 95

lateralis carinata, 81, 84, 95

sp., 82, 95

tectulostoma, 71, 74, 76, 78, 86, 88, 95

parri, Lagena, 84, 95

Patellina corrugata, 11

Pateoris hauerinoides, 71, 74, 75, 84, 86, 88 , 95; pl. 4

pauciloculum albiumbilicatum, Nonion, 93 pauperata, Dentalina, 84, 93; pl. 1

Pelukian, 1, 3, 5, 6, 7, 8, 9, 10, 13, 14, 15, 16 $17,18,19,20,21,22,23,24,25,26,27$, $28,29,30,31,32,33,34,35,36,37,38$, $39,40,41,42,43,44,45,46,47,48,49$, $51,52,53,54,55,56,57,59,60,61,62$, $63,64,65$

platyforma, Limnocythere, 39

Polymorphina

(Polymorphien) cylindroides, 95

spp., 72, 75, 81, 82, 86, 95

suboblonga, $70,71,72,73,74,75,76,78$, $79,80,81,84,86,88,95$; pl. 4

polymorphinids, 11,50

Portlandia, 8

problema, Guttulina, 88, 94

Protelphidium nanum, 94

Psammospheara fusca, 11

Pseudopolymorphina

curta, 94

novangliae, $76,88,95$

soldanii, 75,95

suboblonga, 95

pseudopunctata, Bolivina, 42, 44, 81, 93

pseudopunctillata, Paracyprideis, 17, 38

Pullenia sp., 80, 95

Pulvinulina frigida, 93

Pyrgo williamsoni, 11, 72, 75, 82, 84, 86, 88, 95

Pyrulina cylindroides, 74, 75, 78, 79, 86, 88, 95

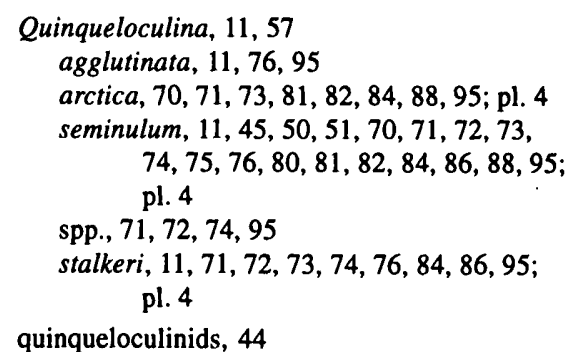

\section{$\mathbf{R}$}

ramosa, Saccorhiza, 11

rectangulata, Candona, 39

Recurvoides turbinatus, 11

regularis, Reophax, 11

Reophax

arctica, 11

curtus, $11,39,80,96$

guttifer, 11

regularis, 11

spp., 73, 82, 96; pl. 4

rotaliformis, Trochammina, 73, 96; pl. 4

\section{$\mathbf{S}$}

Saccorhiza ramosa, 11

Sagavanirktok Formation, 50

Sagavanirktok River glaciation, 3

Sangamon interglacial, 4, 5, 9

Sarsicytheridea bradii, 16

schreibersiana,

Fursenkoina, 57, 71, 81, 82, 84, 88, 94

Virgulina, 94

Scutuloris, 11

tegminis, $11,50,71,72,73,74,75,76,81$, $82,84,86,96 ;$ pl. 4

semimarginata, Fissurina, 76, 88, 94; pl. 3

seminulum, Quinqueloculina, 11, 45, 50, 51, 70, $71,72,73,74,75,76,80,81,82,84,86$, 88,95 ; pl. 4

serrata, Fissurina, $73,75,84,94$; pl. 3

Shaviovik gravel unit, $6,7,8,9,25,26,29,30$, $34,35,36,37,39,40,54,55,60,63$

Sigmomorphina sp., 84, 96

Simpsonian, 1, 3, 4, 5, 6, 7, 8, 10, 12, 13, 14, 15, $16,17,19,20,21,22,23,24,25,26,27$, $28,29,30,31,32,33,34,35,36,41,42$, $43,44,45,46,47,48,49,51,54,55,56$, $57,59,60,61,62,63,64,65$

soldanii, Pseudopolymorphina, 75, 95

Spiroplectammina biformis, 11, 18, 21, 22, 72 , 73, 96; pl. 4

Staines River unit, 6, 7, 8, 30, 32, 47, 48, 54

Stainforthia

complanata, 11

concava, 11, 14, 15, 18, 19, 20, 21, 31, 33, $34,42,43,44,45,49,51,53,54,56$, $57,71,72,73,75,76,81,82,84,86$, 88,$96 ;$ pl. 4

fusiformis, 11 


\section{LATE CENOZOIC BENTHIC FORAMINIFERS OF THE HLA BOREHOLE SERIES, BEAUFORT SEA SHELF, ALASKA}

stalkeri, Quinqueloculina, 11, 71, 72, 73, 74, 76, $84,86,95 ;$ pl. 4

Stefansson Sound unit, 6, 7, 10, 25, 27, 36, 37, $39,40,57,64$

suboblonga,

Polymorphina, 70, 71, 72, 73, 74, 75, 76, 78, $79,80,81,84,86,88,95 ;$ pl. 4

Pseudopolymorphina, 95

sulcata laevicosta, Lagena, 76, 86, 95

\section{$\mathbf{T}$}

tectulostoma, Parafissurina, 71, 74, 76, 78, 86, 88,95

tegminis, Scutuloris, 11, 50, 71, 72, 73, 74, 75,

$76,81,82,84,86,96 ; \mathrm{pl} .4$

teretis, Cassidulina, 11

Textularia torquata, 11

torquata, Textularia, 11

trihedra, Triloculina, 11, 14, 20, 30, 71, 72, 73,

$74,75,76,78,79,81,82,84,86,88,96$
Triloculina, 11, 25

oblongata, 11

trihedra, 11, 14, 20, 30,71, 72, 73, 74, 75,

76, 78, 79, 81, 82, 84, 86, 88, 96

chammina

bullata, 11

nana, 11

rotaliformis, 73, 96; pl. 4

sp., 72,96

Trochamminella atlantica, 39, 71, 80, 81, 96 turbinatus, Recurvoides, 11

\section{$\mathbf{U}$}

ustulatum

Cribroelphidium, 93

Elphidium, 1, 5, 50, 57, 58, 84, 86, 94; pl. 2

$\mathbf{v}$

ventricosa, Fissurina, 71, 74, 88, 94
Virgulina

loeblichi, 94

schreibersiana, 94

vitrea, Epistominella, 18, 19, 31, 33, 34, 43, 44, $53,54,56,57,70,72,74,75,76,81,86$, 88,94

Valvulineria arctica, 74, 96

$\mathbf{W}$

Wainwrightian, 1, 3, 4, 5, 6, 7, 8, 9, 14, 16, 17,

$18,19,22,23,24,27,28,29,30,31,32$,

$33,34,41,42,43,44,45,46,47,48,49$,

$50,51,52,53,54,55,56,57,58,59,60$, 62,63

Wisconsin glacial, 3, 4, 10, 30, 58, 59, 65

williamsoni, Pyrgo, 11, 72, 75, 82, 84, 86, 88, 95

zaandamae,

Melonis, 11, 49, 50, 84, 95; pl. 4

Nonion, 95 


\section{PLATE 1}

Figure 1. Buccella frigida (Cushman)

Borehole HLA 4, sample 4-2. Bar equals $100 \mu \mathrm{m}$.

2. Cassidulina islandica Norvang

Borehole HLA 18, sample 18-21. Bar equals $100 \mu \mathrm{m}$.

3. Cassidulina norcrossi Cushman

Borehole HLA 17, sample 17-2. Bar equals $200 \mu \mathrm{m}$.

4. Cibicides lobatulus (Walker and Jacob)

Borehole HLA 18, sample 18-5. Bar equals $200 \mu \mathrm{m}$

5. Cyclogyra involvens (Reuss)

Borehole HLA 18, sample 18-1. Bar equals $200 \mu \mathrm{m}$.

6. Dentalina frobisherensis Loeblich and Tappan

Borehole HLA 4, sample 4-11. Bar equals $200 \mu \mathrm{m}$.

7. Dentalina ittai Loeblich and Tappan

Borehole HLA 4, sample 4-13. Bar equals $100 \mu \mathrm{m}$.

8. Dentalina pauperata d'Orbigny

Borehole HLA 18, sample 18-24. Bar equals $1 \mathrm{~mm}$.

9. Discorbis baccata (Heron-Allen and Earland)

Borehole HLA 4, sample 4-3. Bar equals $40 \mu \mathrm{m}$.

10. Eggerella advena (Cushman)

Borehole HLA 12, sample 12-12. Bar equals $100 \mu \mathrm{m}$.

11. Elphidiella? brunnescens Todd

Borehole HLA 18, sample 18-35. Bar equals $200 \mu \mathrm{m}$.

12. Elphidiella? brunnescens Todd

Worn specimen. Borehole HLA 18, sample 18-34. Bar equals $100 \mu \mathrm{m}$.

13. Elphidiella groenlandica (Cushman)

Borehole HLA 4, sample 4-8. Bar equals $200 \mu \mathrm{m}$. 

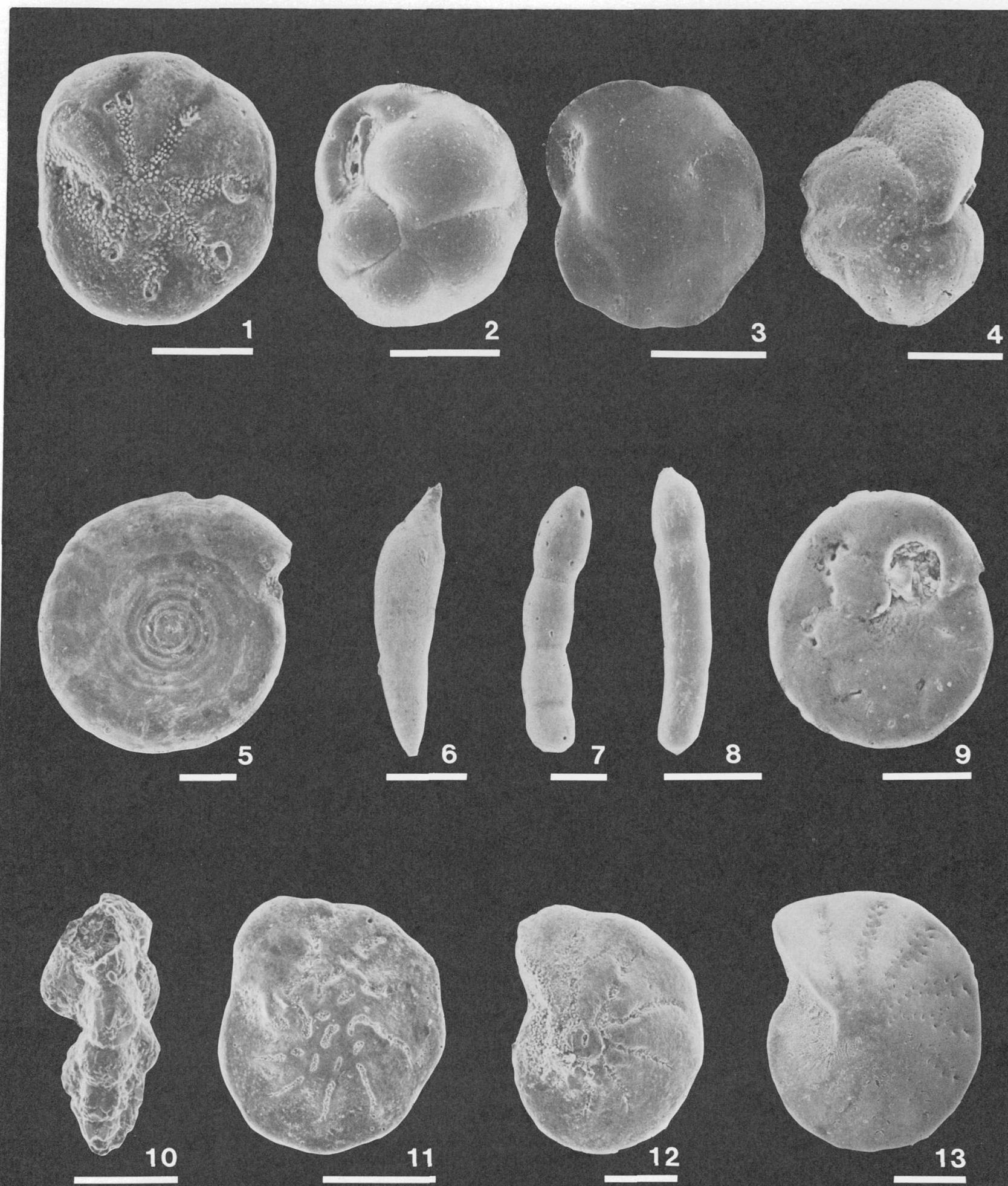

BUCCELLA, CASSIDULINA, CIBICIDES, CYCLOGYRA, DENTALINA, DISCORBIS, EGGERELLA, ELPHIDIELLA?, AND ELPHIDIELLA 


\section{PLATE 2}

Figure 1. Elphidium albiumbilicatum (Weiss)

Borehole HLA 4, sample 4-2. Bar equals $100 \mu \mathrm{m}$.

2. Elphidium asklundi Brotzen

Borehole HLA 4, sample 4-2. Bar equals $100 \mu \mathrm{m}$.

3. Elphidium bartletti Cushman

Borehole HLA 18, sample 18-1. Bar equals $200 \mu \mathrm{m}$.

4. Elphidium clavatum Cushman

Borehole HLA 18, sample 18-1. Bar equals $100 \mu \mathrm{m}$.

5. Elphidium clavatum Cushman

Borehole HLA 4, sample 4-1. Bar equals $100 \mu \mathrm{m}$.

6. Elphidium excavatum alba Feyling-Hanssen

Borehole HLA 19, sample 19-3. Bar equals $100 \mu \mathrm{m}$.

7. Elphidium frigidum Cushman

Borehole HLA 4, sample 4-2. Bar equals $100 \mu \mathrm{m}$.

8. Elphidium nanum Vilks

Borehole HLA 4, sample 4-3. Bar equals $100 \mu \mathrm{m}$.

9. Elphidium incertum (Williamson)

Borehole HLA 6, sample 6-1. Bar equals $100 \mu \mathrm{m}$.

10. Elphidium orbiculare (Brady)

Borehole HLA 18, sample 18-21. Bar equals $100 \mu \mathrm{m}$.

11. Elphidium ustulatum Todd

This form has very short slits along suture lines as in

E. incertum. Borehole HLA 18, sample 18-30. Bar equals $100 \mu \mathrm{m}$.

12. Elphidium ustulatum Todd

This form has slits along the suture line, but these are not as broad as in typical E. ustulatum. Borehole HLA 18, sample 18-31. Bar equals $100 \mu \mathrm{m}$. 


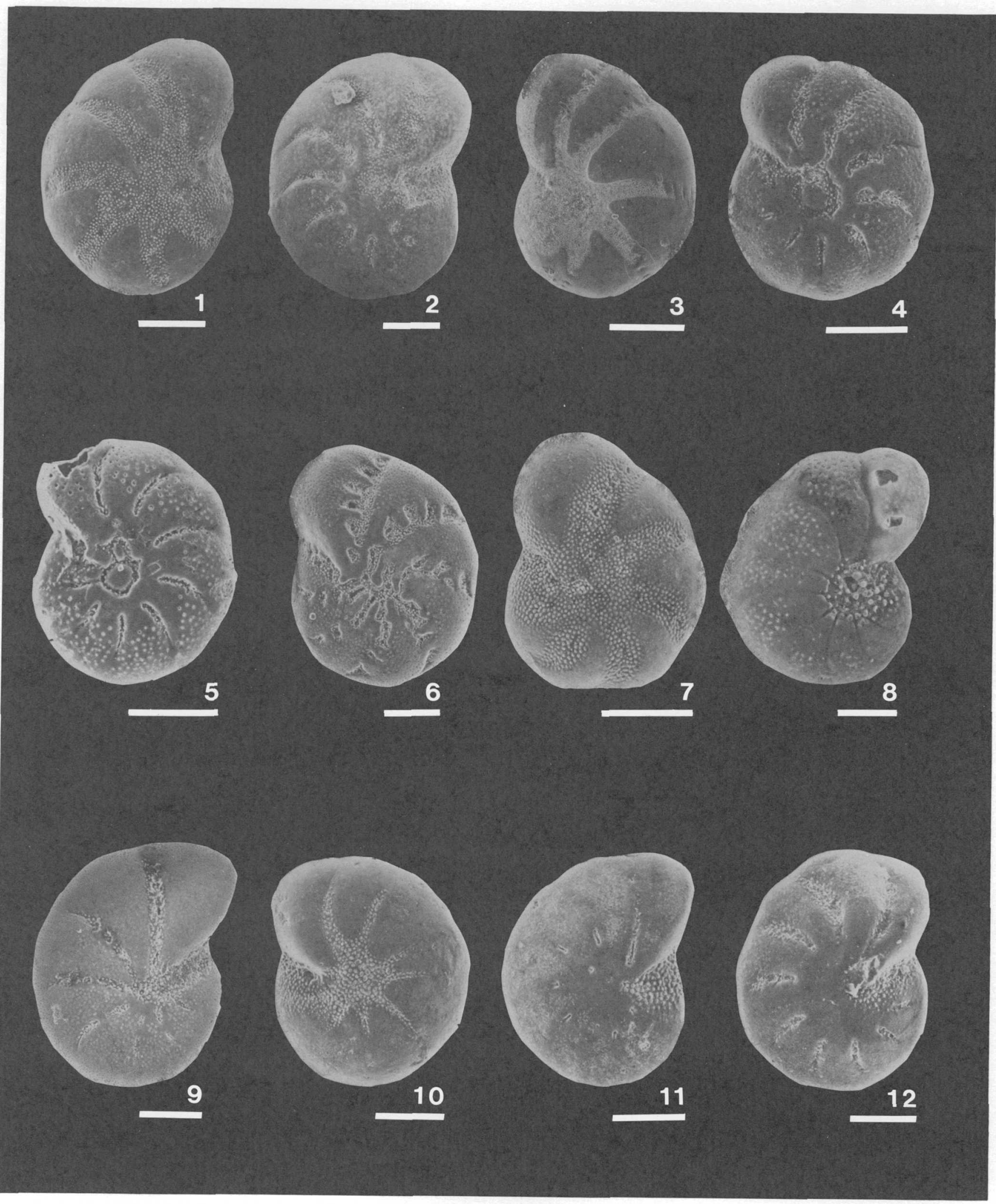




\section{PLATE 3}

Figure 1. Fissurina danica (Madsen)

Borehole HLA 12, sample 12-7. Bar equals $100 \mu \mathrm{m}$.

2. Fissurina semimarginata (Reuss)

Borehole HLA 20, sample 20-4. Bar equals $100 \mu \mathrm{m}$.

3. Fissurina serrata (Schlumberger)

Borehole HLA 18, sample 18-30. Bar equals $100 \mu \mathrm{m}$.

4. Fursenkoina loeblichi (Feyling-Hanssen)

Borehole HLA 12, sample 12-10. Bar equals $100 \mu \mathrm{m}$.

5. Glandulina laevigata (d'Orbigny)

Borehole HLA 12, sample 12-3. Bar equals $200 \mu \mathrm{m}$.

6. Gordiospira arctica Cushman

Borehole HLA 18, sample 18-31. Bar equals $100 \mu \mathrm{m}$.

7. Guttulina dawsoni Cushman and Ozawa

Borehole HLA 18, sample 18-1. Bar equals $200 \mu \mathrm{m}$.

8. Guttulina glacialis (Cushman and Ozawa)

Borehole HLA 18, sample 18-1. Bar equals $100 \mu \mathrm{m}$.

9. Lagena costata (Williamson)

Borehole HLA 6, sample 6-2. Bar equals $100 \mu \mathrm{m}$.

10. Lagena gracillima (Sequenza)

Borehole HLA 4, sample 4-13. Bar equals $200 \mu \mathrm{m}$.

11. Lagena hexagona (Williamson)

Borehole HLA 12, sample 12-3. Bar equals $100 \mu \mathrm{m}$.

12. Lagena laevis (Montagu)

Borehole HLA 18, sample 18-31. Bar equals $200 \mu \mathrm{m}$.

13. Lagena mollis Cushman

Borehole HLA 7, sample 7-13. Bar equals $100 \mu \mathrm{m}$.

14. Lagena sp.

Borehole HLA 4, sample 4-13. Bar equals $100 \mu \mathrm{m}$.

15. Miliolinella chukchiensis Loeblich and Tappan

Borehole HLA 18, sample 18-10. Bar equals $100 \mu \mathrm{m}$. 

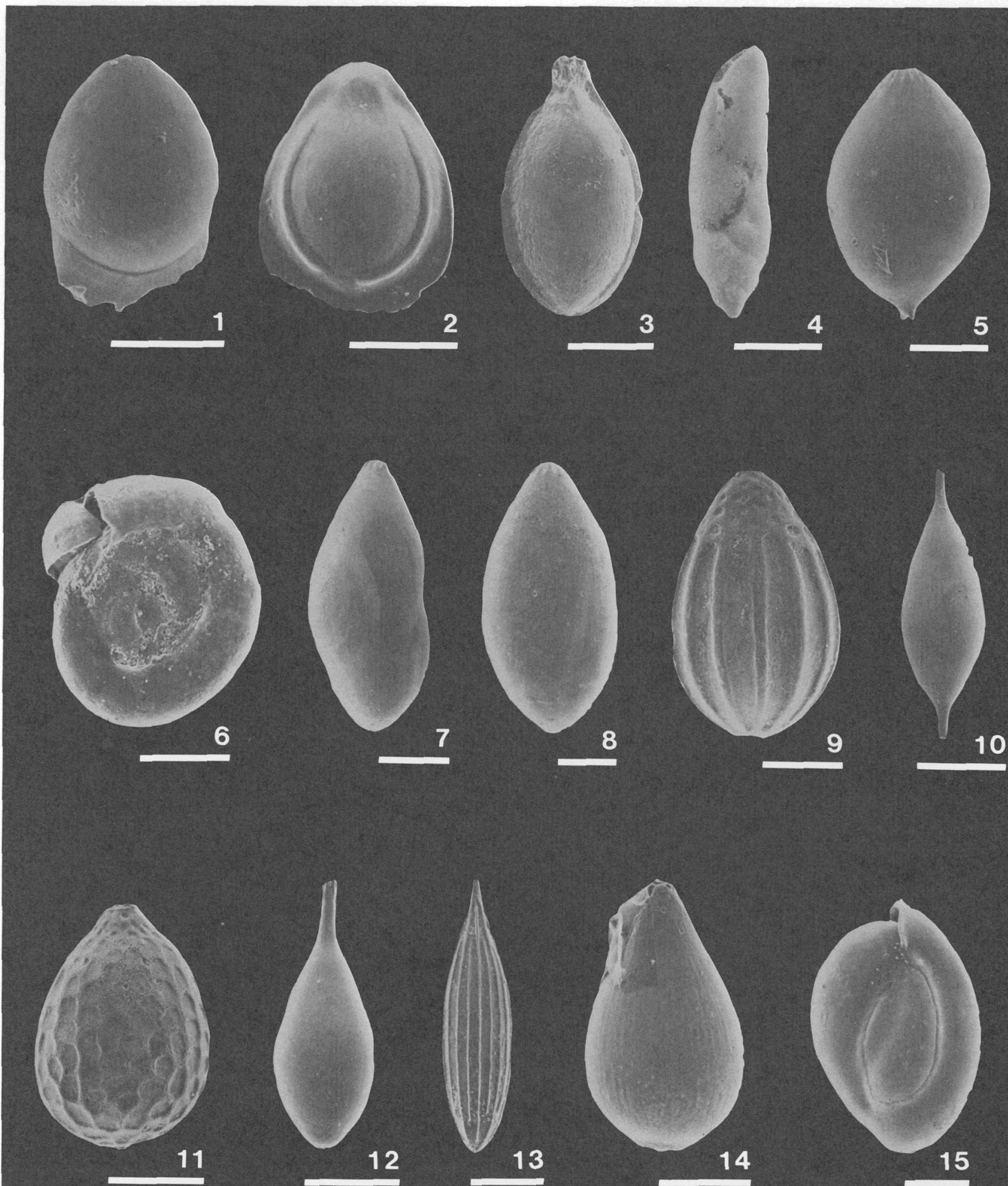

FISSURINA, FURSENKOINA, GLANDULINA, GORDIOSPIRA, GUTTULINA, LAGENA, AND MILIOLINELLA 


\section{PLATE 4}

Figure 1. Melonis zaandamae (van Voorthuysen)

Borehole HLA 18, sample 18-31. Bar equals $200 \mu \mathrm{m}$.

2. Nonionella auricula Heron-Allen and Earland

Borehole HLA 12, sample 12-10. Bar equals $200 \mu \mathrm{m}$.

3. Oolina lineatopunctata (Heron-Allen and Earland)

Borehole HLA 17, sample 17-8. Bar equals $100 \mu \mathrm{m}$.

4. Oolina melo d'Orbigny

Borehole HLA 12, sample 12-7. Bar equals $100 \mu \mathrm{m}$.

5. Pateoris hauerinoides (Rhumbler)

Borehole HLA 18, sample 18-31. Bar equals $200 \mu \mathrm{m}$.

6. Polymorphina suboblonga (Cushman and Ozawa)

Borehole HLA 12, sample 12-2. Bar equals $200 \mu \mathrm{m}$.

7. Quinqueloculina arctica Cushman

Borehole HLA 4, sample 4-2. Bar equals $200 \mu \mathrm{m}$.

8. Quinqueloculina seminulum (Linne)

Borehole HLA 17, sample 17-5. Bar equals $100 \mu \mathrm{m}$.

9. Quinqueloculina stalkeri Loeblich and Tappan

Borehole HLA 6, sample 6-3. Bar equals $100 \mu \mathrm{m}$.

10. Reophax spp.

Borehole HLA 7, sample 7-1. Bar equals $200 \mu \mathrm{m}$.

11. Scutuloris tegminis Loeblich and Tappan

Borehole HLA 18, sample 18-1. Bar equals $100 \mu \mathrm{m}$.

12. Spiroplectammina biformis (Parker and Jones)

Borehole HLA 6, sample 6-1. Bar equals $100 \mu \mathrm{m}$.

13. Stainforthia concava (Hoeglund)

Borehole HLA 4, sample 4-11. Bar equals $200 \mu \mathrm{m}$.

14. Trochammina rotaliformis Wright

Borehole HLA 7, sample 7-1. Bar equals $100 \mu \mathrm{m}$. 


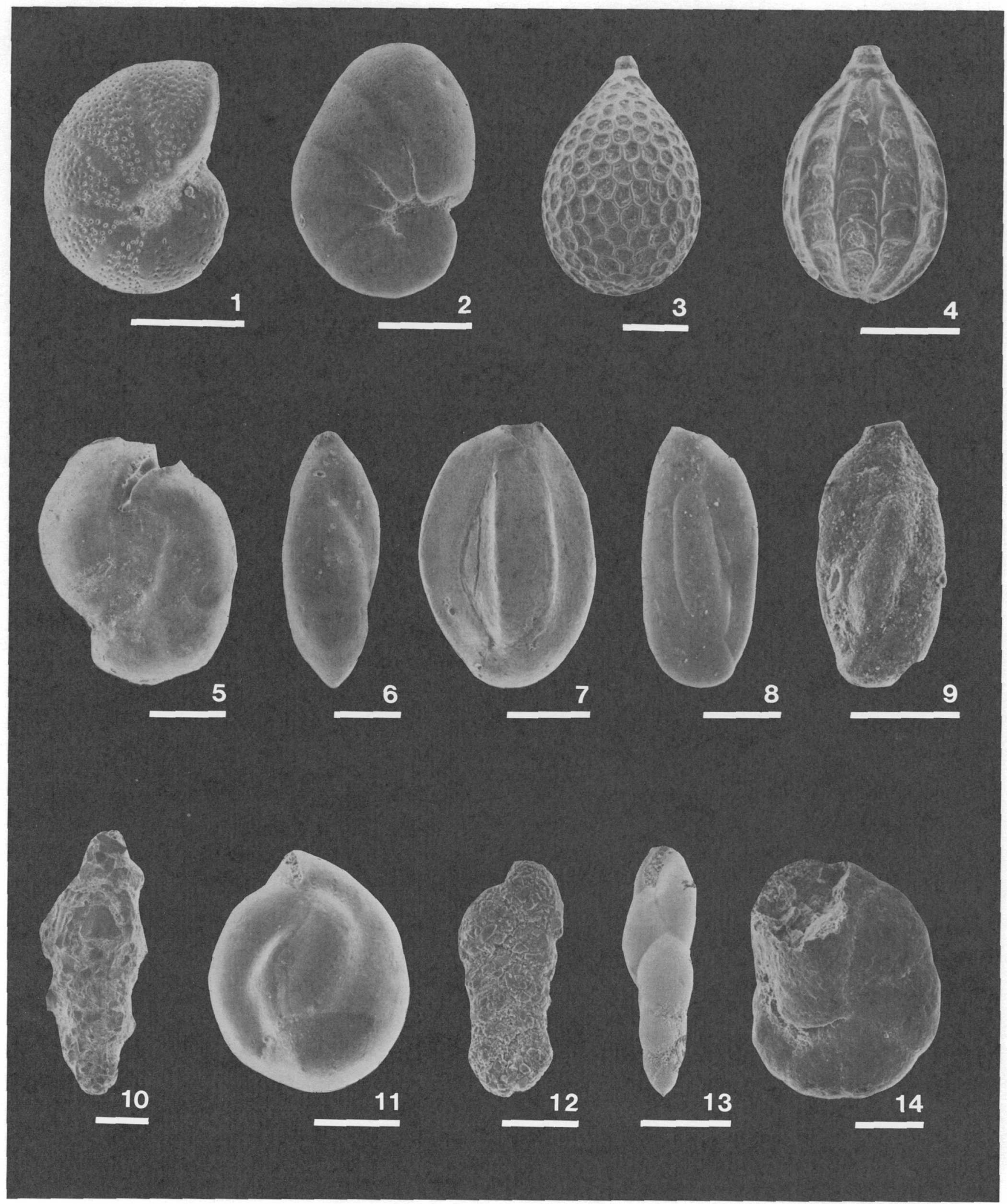

MELONIS, NONIONELLA, OOLINA, PATEORIS, POLYMORPHINA, QUINQUELOCULINA, REOPHAX, SCUTULORIS, SPIROPLECTAMMINA, STAINFORTHIA, AND TROCHAMMINA 


\section{SELECTED SERIES OF U.S. GEOLOGICAL SURVEY PUBLICATIONS}

\section{Periodicals}

Earthquakes \& Volcanoes (issued bimonthly).

Preliminary Determination of Epicenters (issued monthly).

\section{Technical Books and Reports}

Professional Papers are mainly comprehensive scientific reports of wide and lasting interest and importance to professional scientists and engineers. Included are reports on the results of resource studies and of topographic, hydrologic, and geologic investigations. They also include collections of related papers addressing different aspects of a single scientific topic.

Bulletins contain significant data and interpretations that are of lasting scientific interest but are generally more limited in scope or geographic coverage than Professional Papers. They include the results of resource studies and of geologic and topographic investigations, as well as collections of short papers related to a specific topic.

Water-Supply Papers are comprehensive reports that present significant interpretive results of hydrologic investigations of wide interest to professional geologists, hydrologists, and engineers. The series covers investigations in all phases of hydrology, including hydrogeology, availability of water, quality of water, and use of water.

Circulars present administrative information or important scientific information of wide popular interest in a format designed for distribution at no cost to the public. Information is usually of shortterm interest.

Water-Resource Investigations Reports are papers of an interpretive nature made available to the public outside the formal USGS publications series. Copies are reproduced on request unlike formal USGS publications, and they are also available for public inspection at depositories indicated in USGS catalogs.

Open-File Reports include unpublished manuscript reports, maps, and other material that are made available for public consultation at depositories. They are a nonpermanent form of publication that may be cited in other publications as sources of information.

\section{Maps}

Geologic Quadrangle Maps are multicolor geologic maps on topographic bases in 71/2-or 15-minute quadrangle formats (scales mainly $1: 24,000$ or $1: 62,500$ ) showing bedrock, surficial, or engineering geology. Maps generally include brief texts; some maps include structure and columnar sections only.

Geophysical Investigations Maps are on topographic or planimetric bases at various scales; they show results of surveys using geophysical techniques, such as gravity, magnetic, seismic, or radioactivity, which reflect subsurface structures that are of economic or geologic significance. Many maps include correlations with the geology.

Miscellaneous Investigations Series Maps are on planimetric or topographic bases of regular and irregular areas at various scales; they present a wide variety of format and subject matter. The series also includes 7 1/2-minute quadrangle photogeologic maps on planimetric bases that show geology as interpreted from aerial photographs. Series also includes maps of Mars and the Moon.
Coal Investigations Maps are geologic maps on topographic or planimetric bases at various scales showing bedrock or surficial geology, stratigraphy, and structural relations in certain coal-resource areas.

Oil and Gas Investigations Charts show stratigraphic information for certain oil and gas fields and other areas having petroleum potential.

Miscellaneous Field Studies Maps are multicolor or black-andwhite maps on topographic or planimetric bases on quadrangle or irregular areas at various scales. Pre-1971 maps show bedrock geology in relation to specific mining or mineral-deposit problems; post-1971 maps are primarily black-and-white maps on various subjects, such as environmental studies or wilderness mineral investigations.

Hydrologic Investigations Atlases are multicolor or black-andwhite maps on topographic or planimetric bases presenting a wide range of geohydrologic data of both regular and irregular areas; principal scale is $1: 24,000$, and regional studies are at 1:250,000 scale or smaller.

\section{Catalogs}

Permanent catalogs, as well as some others, giving comprehensive listings of U.S. Geological Survey publications are available under the conditions indicated below from the U.S. Geological Survey, Books and Open-File Reports Sales, Federal Center, Box 25286, Denver, CO 80225. (See latest Price and Availability List.)

"Publications of the Geological Survey, 1879-1961" may be purchased by mail and over the counter in paperback book form and as a set of microfiche.

"Publications of the Geological Survey, 1962-1970" may be purchased by mail and over the counter in paperback book form and as a set of microfiche.

"Publications of the Geological Survey, 1971-1981" may be purchased by mail and over the counter in paperback book form (two volumes, publications listing and index) and as a set of microfiche.

Supplements for 1982, 1983, 1984, 1985, 1986, and for subsequent years since the last permanent catalog may be purchased by mail and over the counter in paperback book form.

State catalogs, "List of U.S. Geological Survey Geologic and Water-Supply Reports and Maps For (State)," may be purchased by mail and over the counter in paperback booklet form only.

"Price and Availability List of U.S. Geological Survey Publications, " issued annually, is available free of charge in paperback booklet form only.

Selected copies of a monthly catalog "New Publications of the U.S. Geological Survey" are available free of charge by mail or may be obtained over the counter in paperback booklet form only. Those wishing a free subscription to the monthly catalog "New Publications of the U.S. Geological Survey" should write to the U.S. Geological Survey, 582 National Center, Reston, VA 22092.

Note.--Prices of Government publications listed in older catalogs, announcements, and publications may be incorrect. Therefore, the prices charged may differ from the prices in catalogs, announcements, and publications. 